UNIVERSIDADE DE SÃO PAULO

FACULDADE DE ECONOMIA, ADMINISTRAÇÃO E CONTABILIDADE DEPARTAMENTO DE PÓS-GRADUAÇÃO

PROGRAMA DE PÓS-GRADUAÇÃO EM ADMINISTRAÇÃO

A RELAÇÃO ENTRE GRUPOS DE EVENTOS DE APRENDIZAGEM E DESENVOLVIMENTO DE COMPETÊNCIAS INDIVIDUAIS

Wagner Toyama Cassimiro

Orientadora: Profa. Dra. Marisa Pereira Eboli 
Prof. Dr. João Grandino Rodas

Reitor da Universidade de São Paulo

Prof. Dr. Carlos Roberto Azzoni

Diretor da Faculdade de Economia, Administração e Contabilidade

Prof. Dr. Adalberto Américo Fischmann

Chefe do Departamento de Administração

Prof. Dr. Lindolfo Galvão de Albuquerque

Coordenador do Programa de Pós-Graduação em Administração 


\section{A RELAÇÃO ENTRE GRUPOS DE EVENTOS DE APRENDIZAGEM E DESENVOLVIMENTO DE COMPETÊNCIAS INDIVIDUAIS}

Dissertação apresentada ao Departamento de Pós-Graduação em Administração da Faculdade de Economia, Administração e Contabilidade da Universidade de São Paulo como parte do requisito para a obtenção do título de Mestre em Administração.

Orientadora: Profa. Dra. Marisa Pereira Eboli 


\section{FICHA CATALOGRÁFICA}

Elaborada pela Seção de Processamento Técnico do SBD/FEA/USP

Cassimiro, Wagner Toyama

A relação entre grupos de eventos de aprendizagem e desenvolvimento de competências individuais / Wagner Toyama Cassimiro. -- São Paulo, 2009.

$187 \mathrm{p}$.

Dissertação (Mestrado) - Universidade de São Paulo, 2009.

Bibliografia.

1. Administração de recursos humanos 2. Educação informal 3. Competência profissional - Desenvolvimento 4. Aprendizagem 5. Treinamento de pessoal I. Universidade de São Paulo. Faculdade de Economia, Administração e Contabilidade II. Título.

$$
\text { CDD }-658.3
$$


A Deus e a meus pais na terra. 
Embora seja solitário o processo de redação de uma dissertação, seria impossível realizá-la sem o apoio e a colaboração de professores, amigos e família.

Antes da imensa fila, agradeço minha querida orientadora, Professora Marisa Eboli. Sua capacidade em me dar liberdade para expandir em idéias, somado a sua capacidade em concatenar minhas divagações para um objetivo foram essenciais para o produto deste trabalho.

Ao meu pai, Jonas, e a minha mãe, Lúcia, por me darem a vida, a educação que tive desde criança e a valorização do estudo e do esforço. Aos meus irmãos Júnior, Patrícia e Priscila e aos sobrinhos Pedro, Talita e Maria Clara, que quando forem mais velhos entenderão porque o tio não pôde "brincar" tanto com eles neste período. Por algumas vezes escutei: "Nossa tio, você tem mais dever de casa do que eu".

Aos professores da FEA-USP, em especial aos professores Graziella Comini, Luiz Paulo Fávero e Gerlando Augusto. Também, foram relevantes no caráter pessoal e profissional os professores Carlos Roberto Azzoni e Maria Tereza Leme Fleury.

Pelos comentários feitos e "papos acadêmicos" com vários amigos da pós-graduação e interessados no trabalho. Destaco a participação de Eduardo Caruso "Pexe", que me cobrou diariamente o fim do trabalho e contribuiu na revisão, Rafael Fraga "Goiano", Lú Medeiros, José Cláudio Terra, Eliana, Flávio, Hermann, Shi, Lina, William, Saulo, Andres, Fábio, Bia, Matheus, Vanessa e a tantos outros que não me recordo agora.

Além destes, é válido mencionar os amigos que me distraíram do trabalho, afinal não somos máquinas: Felipe, Toca, Baer, Motta, Nerso, Cesinha, Matheus, Goiano, Fabinho, Sandrinho, Mauro, Porkinho, Baxinho, Marcelo, Renato, Leo, Jorge, Vlad, o pessoal da Adm 22, o pessoal do C\&D da FEA, o pessoal da Comissão de formatura e também as amigas mulheres, cuja relação está no anexo $F$ desta dissertação por falta de espaço!

Por fim, agradeço o Programa de Relacionamento com Ex-Alunos, FEA+, a divulgação da pesquisa; a CNPQ a bolsa concedida; a biblioteca da FEA-USP o acervo; as bases de dados internacionais PROQUEST, EBSCO, ERIC, Google e Google Books; e a todos os acadêmicos do mundo que divulgam os seus trabalhos na internet. Muito obrigado! 
"Live as if you were to die tomorrow. Learn as if you were to live forever." Mahatma Gandhi (1869-1948)

\footnotetext{
${ }^{1}$ Tradução: "Viva como se você fosse morrer amanhã. Aprenda como se você fosse viver para sempre"
} 


\section{RESUMO}

Este estudo se propôs a analisar a relação entre grupos de eventos de aprendizagem e desenvolvimento de competência. Buscou-se compreender quais deles eram considerados mais relevantes para o desenvolvimento de diferentes competências do indivíduo no trabalho. Na revisão bibliográfica, quatro grupos de eventos de aprendizagem emergiram: Aprendizagem Conceitual, Aprendizagem Provocada, Aprendizagem Experiencial e Aprendizagem Experiencial Induzida. Estes grupos foram confrontados com quatro tipos de competências que foram selecionados a partir da análise de 28 tipologias: Social, Funcional, Cognitiva e Metacompetência. A pesquisa quantitativa contou com a análise de 223 respondentes válidos. A amostra foi composta por ex-alunos da FEA-USP dos cursos de administração, economia e contabilidade. Foram aplicados testes de análise de variância para avaliar as hipóteses e testes de análise de correspondência para o aprofundamento da análise. Os resultados evidenciaram a importância dos grupos de eventos de aprendizagem informal, sobretudo o de Aprendizagem Experiencial para o desenvolvimento das quatro competências avaliadas. Os grupos de eventos de aprendizagem formal desenvolvem menos todas as competências e são ainda menos

relevantes para o desenvolvimento da Competência Social e da Competência Funcional, em especial para a primeira citada. Além disso, no aprofundamento da análise, 24 eventos tiveram a frequência analisada e foram confrontados com 11 variáveis de perfis. Dos 264 testes Qui-quadrado realizados, 35 deles apresentaram significância estatística, dos quais foi possível analisar a relação entre as categorias em 34 mapas perceptuais gerados pela análise de correspondência. 


\begin{abstract}
This study aims to analyze the relationship between groups of learning events and competence development. It tries to understand which of them were considered the most relevant for the development of different individual competences in the professional field. In the bibliography review, four groups of learning events were found: Conceptual Learning, Experiential Learning, Caused Learning and Experiential Induced Learning. These groups were confronted with four types of competence that were selected after an analysis of 28 typologies: Social, Functional, Cognitive and Metacompetence. The quantitative study had the participation of 223 valid respondents. The sample was composed by FEA-USP's alumni of the following areas - Management, Economics and Accountancy. After, One-way ANOVA tests were done to verify the hypothesis, as well ANACOR tests were run to make a profound study. The results emphasize the importance of the groups of informal learning events, mainly on the Experiential Learning. The groups of formal learning events have a lower development of all competences and they are still less relevant to the development of the Social Competence and the Functional Competence, especially for the first one quoted. Furthermore, in a deeper study, 24 learning events had their frequencies analyzed and they were compared with 11 profile variables. 264 Chi-square tests were done and 35 of them presented statistical significance. On the end, it was possible to analyze the relationship among categories on 34 perceptual maps produced by ANACOR tests.
\end{abstract}




\section{SUMÁRIO}

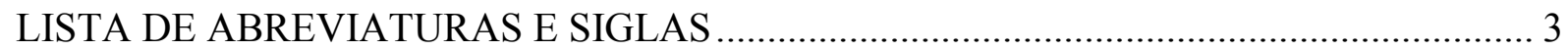

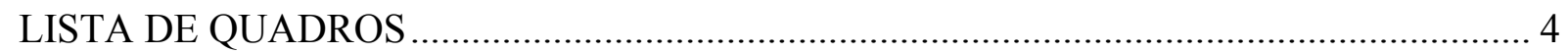

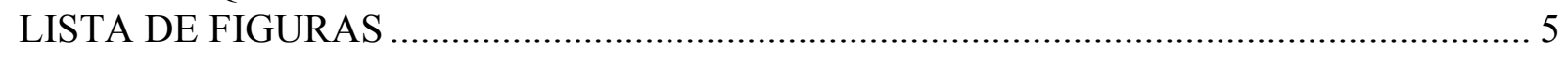

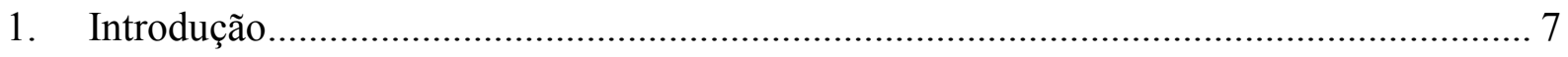

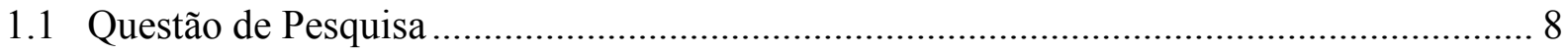

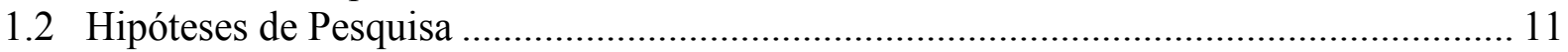

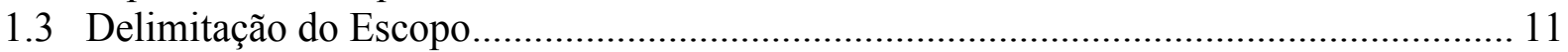

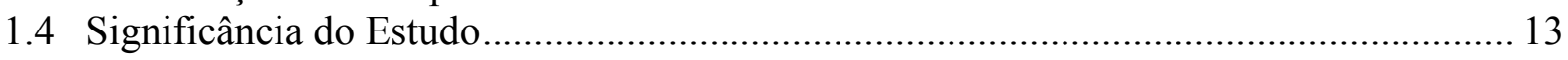

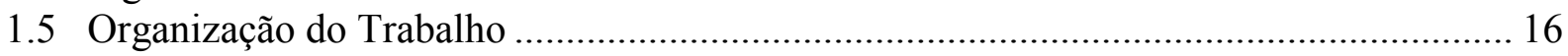

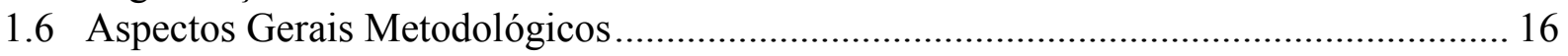

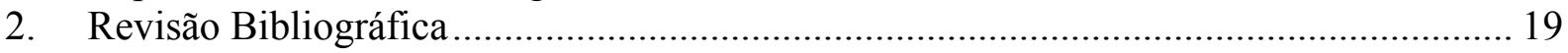

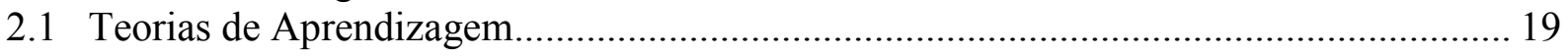

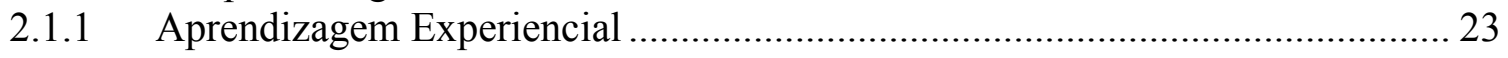

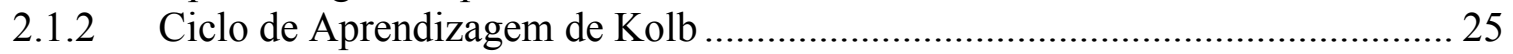

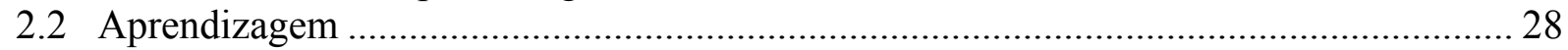

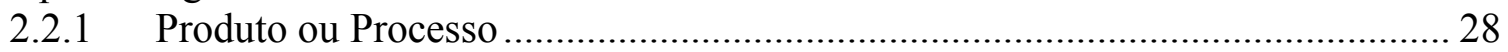

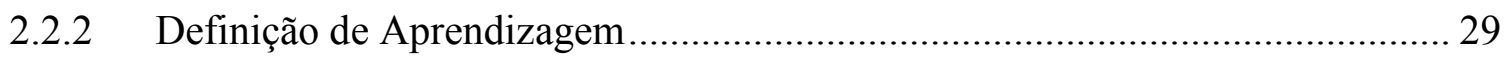

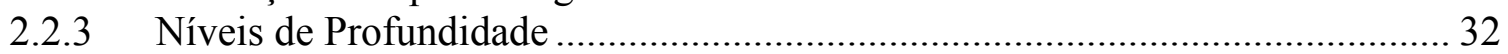

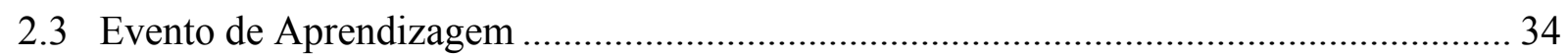

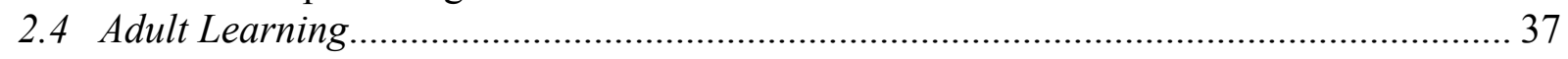

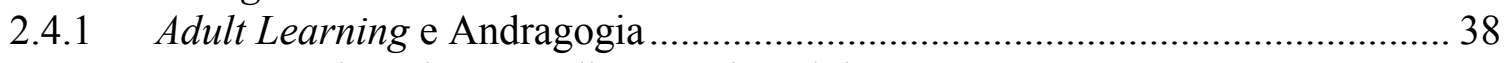

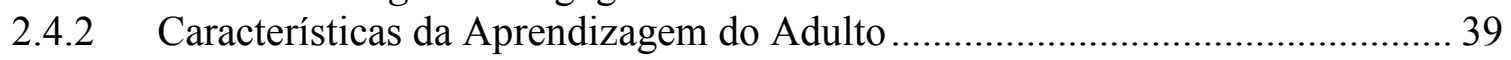

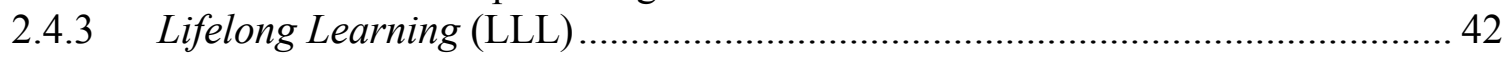

2.5 Estruturas de Classificação de Eventos de Aprendizagem............................................. 44

2.5.1 Manual de Classificação das Atividades de Aprendizagem................................ 44

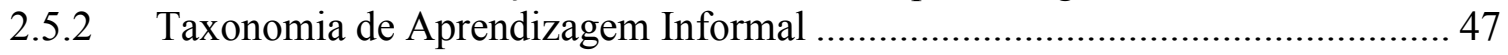

2.5.3 Matriz de Marcia L. Conner.............................................................................. 54

2.6 Análise e Proposta de uma Nova Estrutura ...................................................................... 55

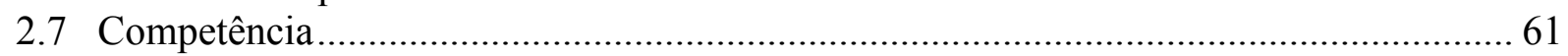

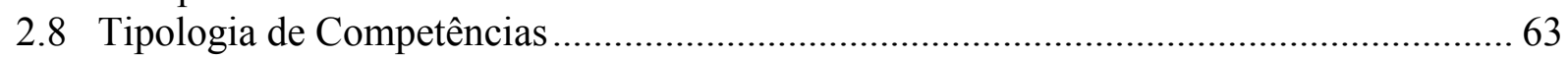

2.9 Análise das Tipologias de Competências ................................................................ 81

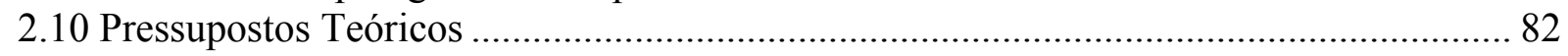

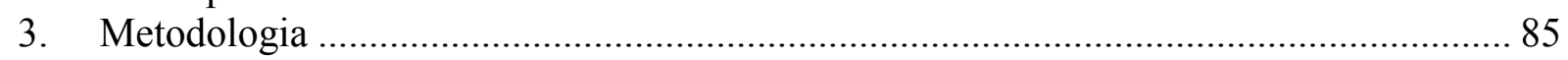

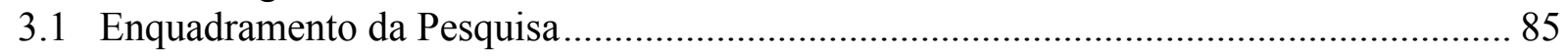

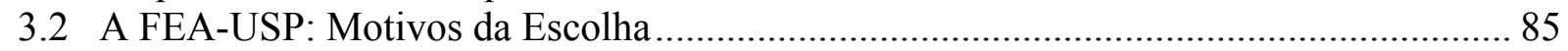

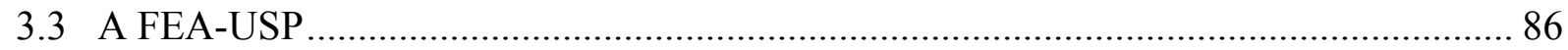

3.3.1 O Programa FEA+: Relacionamento com Ex-alunos ................................... 87

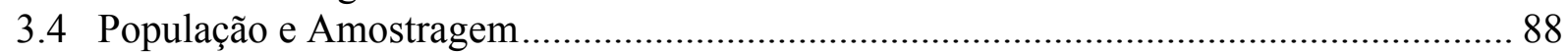

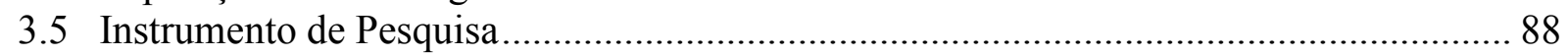

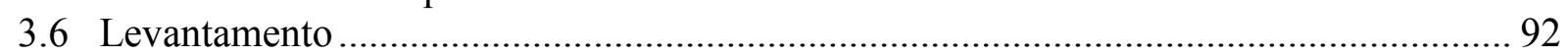

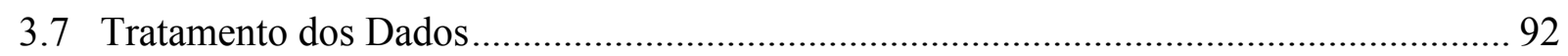

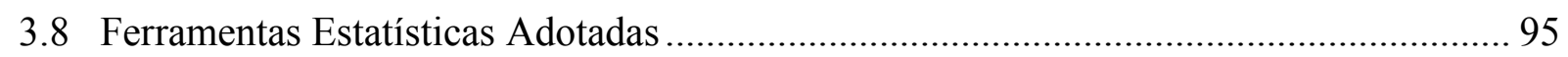

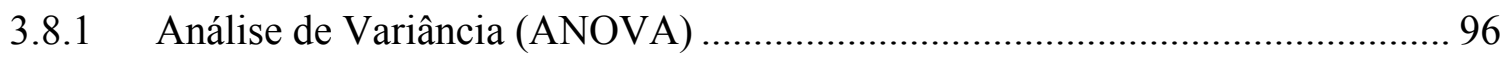

3.8.2 Análise de Correspondência (ANACOR) ..................................................... 98

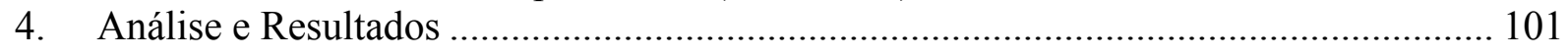

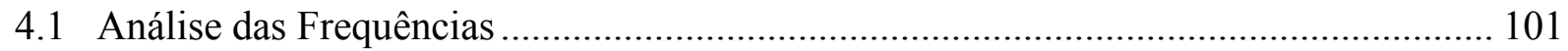




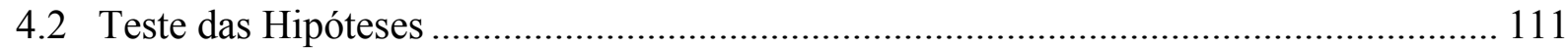

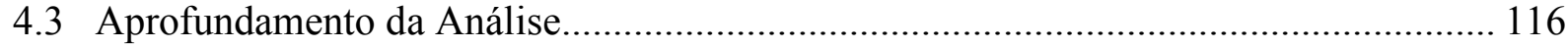

4.4 Aprofundamento da Análise: Eventos de Aprendizagem …………………………….. 122

4.4.1 Eventos de Aprendizagem Experiencial ...................................................... 124

4.4.2 Eventos de Aprendizagem Provocada .............................................................. 135

4.4.3 Eventos de Aprendizagem Conceitual ............................................................ 142

4.4.4 Eventos de Aprendizagem Experiencial Induzida ………………………….... 149

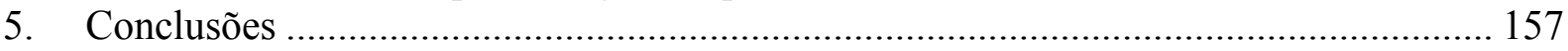

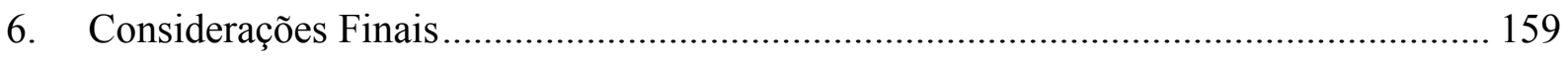

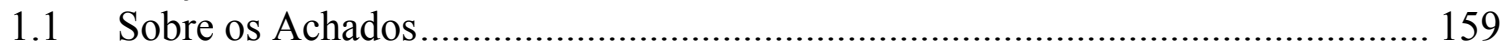

1.2 Limitações do Estudo...…………………………………………………..... 160

1.3 Delineações para Pesquisas Futuras ................................................................ 160

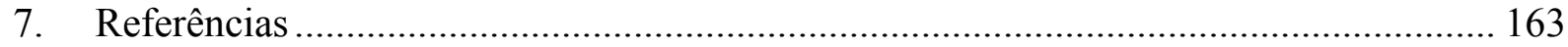

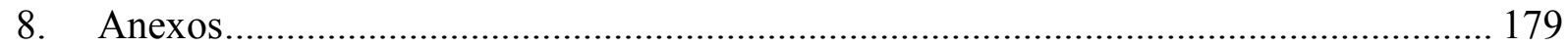




\section{LISTA DE ABREVIATURAS E SIGLAS}

ANOVA: Análise de Variância

ANACOR: Análise de Correspondência

ASTD: American Society of Training and Development

CAPES: Coordenação de Aperfeiçoamento de Pessoal de Nível Superior

CLA: Classification of Learning Activities

DeSeCo: The Definition and Selection of Key Competencies

FEA: Faculdade de Economia, Administração e Contabilidade

GE: General Eletric

HRD: Human Resource Development

IES: Instituições de Ensino Superior

ISCED: International Standard Classification of Education

KSA: Knowledge, Skills and Attitudes

LLL: Lifelong Learning

LSI: Learning Style Inventory

MCI: Management Charter Initiative

NFQ: National Framework of Qualification

NVQs: National Vocational Qualifications

OECD: Organisation for Economic Co-operation and Development

OIT: Organização Internacional do Trabalho

SLA: Single Learning Activity

SVQs: Scottish Vocational Qualifications

UE: União Européia

UNESCO: United Nations Educational Scientific and Cultural Organization

USP: Universidade de São Paulo 


\section{LISTA DE QUADROS}

Quadro 1 - Teorias de aprendizagem. Fonte: MERRIAM \& CAFFARELLA (1991, p. 134) .......................... 20

Quadro 2 - Características obtidas da análise conceitual. Fonte: próprio autor, analisando ibid ........................ 30

Quadro 3 - Definições de aprendizagem. Fonte: análise do autor. Negrito nosso............................................ 31

Quadro 4 - Características do modelo tradicional e LLL (WORLD BANK, 2003, p.29)................................ 43

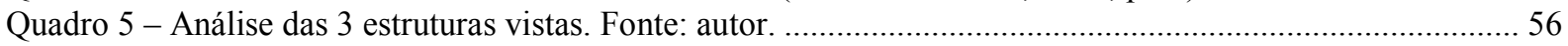

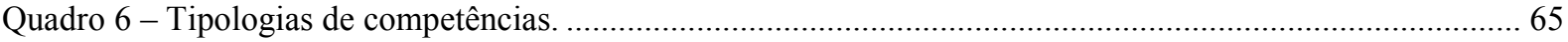

Quadro 7 - Competências relevantes para o desempenho e eficácia em relação às demandas de trabalho: vários

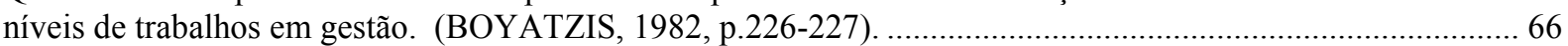

Quadro 8 - Uma tipologia de competência (ibid., p.13) .......................................................................... 71

Quadro 9 - Tipologias de competência nos países. Elaborado pelo autor a partir da análise de OIT (2002)...... 77

Quadro 10 - Tipologias não consideradas (elaborado pelo autor)............................................................. 80

Quadro 11 - Expressões utilizadas no questionário para competências. ........................................................ 89

Quadro 12 - Expressões utilizadas no questionário para grupos de eventos de aprendizagem. ......................... 89

Quadro 13 - Expressões utilizadas para representar os eventos de aprendizagem........................................ 91

Quadro 14 - Métodos estatísticos de dependência (ibid., p.6) ....................................................................... 95

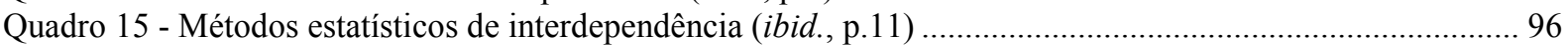

Quadro 16 - Cálculos da ANOVA de um fator (fonte: ibid., 2009). ........................................................... 97

Quadro 17 - Teste Tukey B para a significância das competências para o trabalho....................................... 111

Quadro 18 - Avaliação dos grupos de eventos de aprendizagem pelas competências..................................... 112

Quadro 19 - Valores de significâncias dos testes estatísticos para as competências. ...................................... 112

Quadro 20 - Teste Tukey B para Grupos de Eventos de Aprendizagem e Competência Social. ...................... 113

Quadro 21 - Teste Tukey B para Grupos de Eventos de Aprendizagem e Competência Funcional. ................. 113

Quadro 22 - Teste Tukey B para Grupos de Eventos de Aprendizagem e Competência Cognitiva. ................. 114

Quadro 23 - Teste Tukey B para Grupos de Eventos de Aprendizagem e Metacompetência............................ 114

Quadro 24 - Teste Bonferroni para Grupos de Eventos de Aprendizagem e Metacompetência. ....................... 115

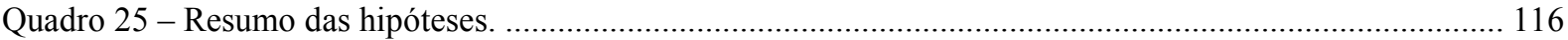

Quadro 26 - Valores de significâncias dos testes estatísticos para os Grupos de Eventos de Aprendizagem..... 117

Quadro 27 - Teste Tukey B para Competências e Aprendizagem Experiencial. .............................................. 117

Quadro 28 - Teste Bonferroni para Competências e Aprendizagem Experiencial........................................ 118

Quadro 29 - Teste Tukey B para Competências e Aprendizagem Provocada................................................. 119

Quadro 30 - Teste Bonferroni para Competências e Aprendizagem Provocada. ............................................ 119

Quadro 31 - Teste Tukey B para Competências e Aprendizagem Conceitual. ................................................. 119

Quadro 32 - Teste Bonferroni para Competências e Aprendizagem Conceitual........................................... 120

Quadro 33 - Teste Tukey B para Competências e Aprendizagem Experiencial Induzida............................... 121

Quadro 34 - Teste Bonferroni para Competências e Aprendizagem Experiencial Induzida............................ 121

Quadro 35 - Resumo dos achados dos testes ANOVA........................................................................... 122

Quadro 36 - Variáveis de eventos de aprendizagem adaptadas.............................................................. 124

Quadro 37 - Resultados dos testes Qui-quadrado para eventos de Aprendizagem Experiencial...................... 126

Quadro 38 - Resultados dos testes Qui-quadrado para eventos de Aprendizagem Provocada.......................... 137

Quadro 39 - Resultados dos testes Qui-quadrado para eventos de Aprendizagem Conceitual. ........................ 144

Quadro 40 - Resultados dos testes Qui-quadrado para eventos de Aprendizagem Experiencial Induzida. ........ 150

Quadro 41 - Resumo dos achados dos testes ANACOR...................................................................... 155 


\section{LISTA DE FIGURAS}

Figura 1 - Dimensões estruturais que suportam o processo de aprendizagem experiencial e as formas de

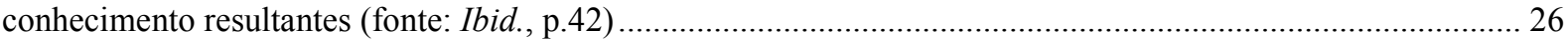
Figura 2 - Dimensão cognitiva da taxonomia de Bloom revisada por Ibid. .................................................. 34 Figura 3 - Matriz de temas por métodos "Learning Map" (ibid., p.12) ........................................................... 35 Figura 4 - Alocação das atividades de aprendizagem segundo as 3 categorias amplas (EUROSTAT, 2006, p.19)

Figura 5 - Contribuição de várias formas de aprendizagem informal para a competência. Fonte: ibid., p.271.... 48

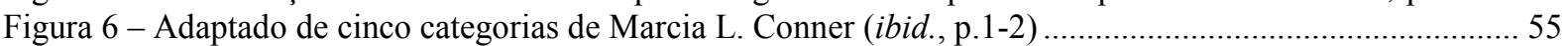

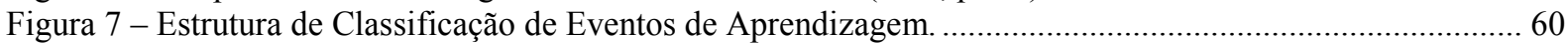

Figura 8 - Classificação das categorias de aprendizagem.........................................................................6. 61 Figura 9 - Representação da tipologia de Le Deist \& Winterton (ibid.). (Análise do autor das figuras das p.3940)

Figura 10 - Ano de nascimento.

Figura 11 - Distribuição dos respondentes segundo a faixa de idade .................................................... 102

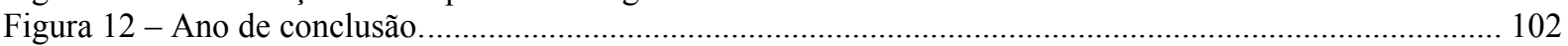

Figura 13 - Distribuição dos respondentes em relação ao curso de graduação na FEA. ................................ 103

Figura 14 - Distribuição dos respondentes segundo a formação. ............................................................. 103

Figura 15 - Distribuição dos respondentes segundo o fato de estar cursando alguma pós. .............................. 104

Figura 16 - Distribuição dos respondentes segundo local de residência.......................................................... 104

Figura 17 - Distribuição dos respondentes segundo o Status profissional..................................................... 105

Figura 18 - Distribuição dos respondentes segundo o nível hierárquico. ................................................... 105

Figura 19 - Distribuição dos respondentes segundo o porte da organização. ............................................... 106

Figura 20 - Distribuição das empresas dos respondentes segundo os setores de atuação................................ 107

Figura 21 - Distribuição das empresas dos respondentes segundo a origem do capital. ................................. 108

Figura 22 - Histograma da distribuição dos respondentes segundo o tempo na organização........................... 109

Figura 23 - Distribuição dos respondentes segundo o tempo na organização............................................... 109

Figura 24 - Gráfico de caixas para a significância da competência para o trabalho..................................... 110

Figura 25 - Painel de gráficos de frequência dos eventos de Aprendizagem Experiencial. ............................. 125

Figura 26 - Mapa das relações entre as categorias de Setor e Conexão de aprendizagem................................ 127

Figura 27 - Mapa das relações entre as categorias de Tipo de organização e Trabalhar em time...................... 128

Figura 28 - Mapa das relações entre as categorias de Idade e Articulação. .................................................... 128

Figura 29 - Mapa das relações entre as categorias de Tipo de organização e Projetos desafiadores. ................. 129

Figura 30 - Mapa das relações entre as categorias de Tempo na organização e Projetos desafiadores............... 130

Figura 31 - Mapa das relações entre as categorias de Status profissional e Mudança de perspectiva................ 130

Figura 32 - Mapa das relações entre as categorias de Setor e Mudança de perspectiva.................................... 131

Figura 33 - Mapa das relações entre as categorias de Tempo na organização e Aprender por osmose. ............. 132

Figura 34 - Mapa das relações entre as categorias de Idade e Ser mentor. .................................................. 132

Figura 35 - Mapa das relações entre as categorias de Formação e Ser mentor. ............................................. 133

Figura 36 - Mapa das relações entre as categorias de Nível hierárquico e Ser mentor. .................................... 133

Figura 37 - Mapa das relações entre as categorias de Porte da organização e Ser mentor................................ 134

Figura 38 - Mapa das relações entre as categorias de Setor e Ser mentor.................................................... 135

Figura 39 - Painel de gráficos de frequência dos eventos de Aprendizagem Provocada. ................................ 136

Figura 40 - Mapa das relações entre as categorias de Status profissional e Mecanismos psicológicos. ............. 138

Figura 41 - Mapa das relações entre as categorias de Idade e Livros técnicos e da área. .................................. 138

Figura 42 - Mapa das relações entre as categorias de Formação e Livros técnicos e da área. ........................... 139

Figura 43 - Mapa das relações entre as categorias de Onde mora e Livros técnicos e da área. ......................... 139

Figura 44 - Mapa das relações entre as categorias de Status profissional e Livros técnicos e da área................ 140

Figura 45 - Mapa das relações entre as categorias de Nível hierárquico e Livros técnicos e da área. ................ 140

Figura 46 - Mapa das relações entre as categorias de Porte da organização e Livros técnicos e da área............ 141

Figura 47 - Mapa das relações entre as categorias de Setor e Livros técnicos e da área................................... 141

Figura 48 - Mapa das relações entre as categorias de Idade e Repetição........................................................ 142

Figura 49 - Painel de gráficos de frequência dos eventos de Aprendizagem Conceitual. ................................. 143

Figura 50 - Mapa das relações entre as categorias de Formação e Aula. .......................................................... 144

Figura 51 - Mapa das relações entre as categorias de Nível hierárquico e Aula. .......................................... 145

Figura 52 - Mapa das relações entre as categorias de Idade e Palestra. ............................................................ 145

Figura 53 - Mapa das relações entre as categorias de Formação e Palestra. .................................................... 146

Figura 54 - Mapa das relações entre as categorias de Nível hierárquico e Palestra. ....................................... 146 
Figura 55 - Mapa das relações entre as categorias de Setor e Palestra......................................................... 147

Figura 56 - Mapa das relações entre as categorias de Tipo de organização e Palestra..................................... 147

Figura 57 - Mapa das relações entre as categorias de Curso e Aula particular. ............................................. 148

Figura 58 - Mapa das relações entre as categorias de Tempo na organização e Aula particular....................... 149

Figura 59 - Painel de gráficos de frequência dos eventos de Aprendizagem Experiencial Induzida. ................ 150

Figura 60 - Mapa das relações entre as categorias de Status profissional e Treinamento on-the-job. ............... 151

Figura 61 - Mapa das relações entre as categorias de Porte da organização e Treinamento on-the-job............. 151

Figura 62 - Mapa das relações entre as categorias de Curso e Estudo de caso. ............................................. 152

Figura 63 - Mapa das relações entre as categorias de Status profissional e Estudo de caso. ........................... 153

Figura 64 - Mapa das relações entre as categorias de Idade e Jogos de empresas. .......................................... 153 


\section{INTRODUÇÃO}

"A relação entre aprendizagem e trabalho é relativamente pouco compreendida e pouco teorizada" (FULLER et al, 2003, p.14). Uma das explicações descreve que a aprendizagem no ambiente de trabalho é um tópico "sem uma casa estabelecida" (BECKETT; HAGER, 2002), já que pode ser abordada por inúmeras perspectivas de disciplinas que a suportam.

Entretanto, ao mesmo tempo em que o assunto é complexo, sua importância é evidente já que a única maneira de evitar a obsolescência é pelo contínuo esforço em adquirir novos conhecimentos e habilidades (LIVNEH, 1998). Mais do que evitar a obsolescência, aprendizagem promove mudança (CELL, 1984), que para Handy $(1990$, p.5) “mudança [...] é apenas outra palavra para crescimento, outro sinônimo para aprendizagem".

Do lado da área de Administração, os estudos focam a aprendizagem do ponto de vista da gestão, ou seja, como Universidades Corporativas (MEISTER, 1999; ALLEN, 1999; EBOLI, 2004) dão suporte às estratégias de negócios, conduzindo programas de desenvolvimento. Entre as formas de atuação, a concentração de atuação está na prática do treinamento, com eventuais ações que envolvem mentoring e coaching.

Já do lado da área de Educação, percebe-se forte interesse em estudar o processo pelo qual o indivíduo aprende. Por isso, as formas de aprendizagem informais são exploradas, principalmente as que focam a prática no dia a dia no trabalho - aprendizagem experiencial (KOLB, 1984; MARSICK; WATKINS, 1990) e aprendizagem casual (Ibid.; ERAUT, 2000).

Outros (MUMFORD, 1993; BURGOYNE; HODGSON,1983; DAVIES; EASTERBYSMITH, 1984) enfatizaram a importância da aprendizagem informal dos gestores e comprovam por meio de entrevistas que o clichê "gestores aprendem com a experiência" tem fundamento (BURGOYNE; HODGSON,1983, p.22).

Verespej (1998) pesquisou quali e quantitativamente diversas plantas de sete importantes empresas americanas ao longo de dois anos. O autor confirmou a importância da aprendizagem informal e quantificou que " $62 \%$ do que os funcionários precisam saber para seu trabalho é adquirido pela aprendizagem informal no ambiente de trabalho" (Ibid., p.42). 
Em resultado próximo, Bruce et al (1998) levantaram que $70 \%$ de todo o aprendizado no ambiente de trabalho é aprendizagem informal.

Estes apontamentos levaram a grandes organizações a implantarem regras de ouro em seus programas de desenvolvimento:

"A GE [General Eletric] desenvolveu a regra 70-20-10 de práticas de desenvolvimento de lideranças, na qual compreende em $70 \%$ de aprendizagem on-the-job, 20\% de aprendizagem por meio de relações fora da área de foco, e $10 \%$ de aprendizagem/treinamento estruturado" (CORPORATE LEADERSHIP COUNCIL, 2004 apud MARSICK et al, 2006).

Obviamente não queremos desqualificar o treinamento, apenas jogar luz sobre a aprendizagem informal para que ambos, em conjunto e de forma integrada, propiciem ganhos de produtividade à organização (VERESPEJ, 1998, p.43) e ganhos ao indivíduo.

Tudo isto posto, é limitado descrever que os resultados da aprendizagem individual são o aprendizado. Por conta disso, o conceito de competência vem à tona como forma de unir a relação entre aprendizagem e trabalho, pois mais do que o desenvolvimento de qualificações "clusters de conhecimentos, habilidades e atitudes" (PARRY, 1996), temos o aprimoramento da mobilização destes inputs para "gerar valor econômico à organização e social ao indivíduo" (FLEURY; FLEURY, 2002), ou em outras palavras, mais do que estoque, competência proporciona "entrega" (DUTRA, 2002).

Por outro lado, competência também é vista como um tópico multidisciplinar pouco tangível, diferenciado e homogêneo e cuja articulação e aplicação são complexas (DIAS et al, 2008). Logo, a relação tornar-se-ia tão ou mais complexa, caso não se desenvolvesse tipologias apropriadas, adotando a lógica de que reduzindo o todo a partes menores, é mais fácil compreender a relação entre as variáveis.

\subsection{Questão de Pesquisa}

Pessoas se desenvolvem quando aprendem. Nações e empresas crescem com o desenvolvimento de seus habitantes e colaboradores, respectivamente. Logo, é importante 
compreender a raiz de todo este desenvolvimento, entender como a aprendizagem desenvolve competências individuais nos profissionais. Entretanto, não pretendemos abordar a aprendizagem do adulto em geral, mas sim o de um tipo específico, daquele profissional que teve formação superior em uma instituição conceituada e que hoje trabalha na condução de organizações ou como especialista em diversas áreas da administração, economia e contabilidade. No inglês, não teríamos problemas para adotar o termo "White-collar worker", comumente usado para definir este público, já no português não é possível estabelecer a associação do termo "colarinho branco", pois tem a conotação de crime e corrupção ${ }^{2}$.

Assim, o objetivo geral desta pesquisa é compreender a relação entre os grupos de eventos de aprendizagem e o desenvolvimento de competências. E, derivando deste propósito, estabelecemos como pergunta de pesquisa:

\section{Quais são os grupos de eventos de aprendizagem considerados pelos profissionais como sendo os mais relevantes para o desenvolvimento de suas competências?}

Para esclarecer, estabeleceremos a definição dos termos operacionais.

Primeiro, precisamos definir o que é uma profissão. Lederman (1998) levantou as características que formam uma profissão a partir de revisão bibliográfica de vários autores (CARR-SAUNDERS; WILSON, 1966; GREENWOOD, 1966; PROFESSORS OF HIGHER EDUCATION, 1975; SCHEIN; KROMER, 1972; STARR, 1982). Assim, uma profissão compreende:

- Corpo de conhecimento: é necessário haver um corpo de conhecimento teórico e prático específicos;

- Período de treinamento: requer educação formal para se formar um profissional na área;

\footnotetext{
${ }^{1} \mathrm{O}$ termo "White-collar worker" foi utilizado pela primeira vez pelo jornalista e escritor americano Upton Clair na década de 1930. Naquela época, assim como um grande período prévio e posterior, era comum nas fábricas ocidentais que os operários usassem roupas de cor azul; as chefias de seção, cor marrom; e, branco para a direção.

${ }^{2}$ Embora o termo "White-collar crimes" tenha sido usado pela primeira vez nos EUA por Edwin Sutherland, em 1939, o significado do termo "White-Collar Worker" manteve-se inalterado. No Brasil, somente o uso da expressão "colarinho branco" já é diretamente associado à corrupção e não às pessoas que trabalham em escritórios. Inclusive, a Lei N7492 de junho de 1986 de Crimes Fiscais contra o Sistema Financeiro Nacional é popularmente conhecida apenas como "Lei do Colarinho Branco".
} 
- Orientação a serviço: o profissional possui competência para a realização de uma demanda;

- Tomada de decisão objetiva: o profissional detém conhecimento para prover decisões fundamentadas;

- Autonomia de julgamento: o profissional é responsável pelo monopólio da decisão, após apurado um problema;

- Regras profissionais: as profissões são regulamentadas por critérios de admissão, licenciamento, linhas de carreira e áreas de atuação dentro da profíssão;

- Código de ética: uma norma de conduta deve ser seguida por todos da profissão para proteger os clientes;

- Regulamentação: geralmente há uma agência relatoria que fiscaliza e valoriza a profissão.

Logo, os profissionais que consideramos neste estudo são os ex-alunos da Faculdade de Economia, Administração e Contabilidade da Universidade de São Paulo (FEA-USP) formados em diversos anos e que trabalham em empresas, Governo e organizações do terceiro setor.

Embora tenhamos um capítulo para definir o termo aprendizagem, apresentamos uma visão singela para constar nesta parte inicial. Deste modo, aprendizagem profissional é o processo que possibilita o desenvolvimento de competências necessárias para o trabalho. Entretanto, a frase é ampla e geral, o que torna a aprendizagem algo aparentemente vago para se explorar. Por isso, analisaremos os eventos (ou oportunidades, ou episódios, ou ações) de aprendizagem organizados conforme a intencionalidade da pessoa em aprender e a organização da tarefa, segundo estrutura proposta pelo autor.

Da mesma forma, nesta fase inicial, a compreensão do termo competência como sendo “entrega" já é satisfatória, visto que a complexidade do assunto demandará um capítulo para a sua correta explanação. Além do mais, para facilitar a compreensão de sua relação com os eventos de aprendizagem, analisamos os tipos de competências existentes.

Estes conceitos são abordados na revisão bibliográfica. 


\subsection{Hipóteses de Pesquisa}

Tendo em vista a questão de pesquisa, formulamos hipóteses que posteriormente serão submetidas a testes:

H01 - Os grupos de eventos de aprendizagem informal são os mais relevantes para o desenvolvimento de competências;

H02 - Dentre os grupos de eventos de aprendizagem informal, destaca-se o grupo de eventos Aprendizagem Experiencial ${ }^{3}$;

H03 - Para o desenvolvimento da Competência Cognitiva, o grupo de eventos de Aprendizagem Conceitual é o mais importante;

H04 - Para o desenvolvimento da Competência Funcional, o grupo de eventos de Aprendizagem Experiencial é o mais importante;

H05 - Para o desenvolvimento da Competência Social, o grupo de evento de Aprendizagem Experiencial é o mais importante;

H06 - Para o desenvolvimento da metacompetência, o grupo de eventos de Aprendizagem Provocada é o mais importante;

H07 - O grupo de eventos de Aprendizagem Experiencial Induzido é o menos importante.

\subsection{Delimitação do Escopo}

Dissertar sobre aprendizagem e competência pode se tornar algo extremamente vasto devido às inúmeras correntes teóricas e tipos de abordagens. É fundamental, portanto, uma boa delimitação do campo de estudo.

Neste trabalho não abordamos todas as correntes teóricas que lidam com aprendizagem do campo da pedagogia, psicologia e sociologia, devido a sua vastidão. Trataremos os temas ligados à aprendizagem do adulto e às correntes que lidam com o desenvolvimento profissional por serem diretamente conectadas ao objetivo desta pesquisa. Os demais

\footnotetext{
${ }^{3}$ Como padrão, as variáveis estudadas serão redigidas com as primeiras letras em caixa-alta e, as categorias terão somente a primeira letra em caixa-alta.
} 
fundamentos teóricos serão tratados em parte conforme apresentarem conexão com os assuntos desta dissertação.

Os conceitos de aprendizagem organizacional e de organizações que aprendem ${ }^{4}$ também não são abordados neste trabalho. A aprendizagem organizacional foca no processo de como as organizações estão aprendendo e vem sendo pesquisada por inúmeros pesquisadores acadêmicos desde a década de 1950 e 1960 (CYERT; MARCH, 1963; CANGELOSI; DILL, 1965; ARGYRIS; SCHÖN, 1978; HEDBERG, 1981; SHRIVASTAVA， 1983; DAFT; WEICK, 1984; FIOL; LYLES, 1985; CROSSAN et al, 1999).

O conceito das organizações de aprendizagem é mais recente - década de 1980 -, e também utiliza a base teórica da aprendizagem organizacional. Entretanto, seu foco de análise é no que as organizações deveriam fazer para aprender, visando à transformação organizacional. Outra diferença é que, enquanto a aprendizagem organizacional promove estudos empíricos, o conceito de organizações de aprendizagem é mais baseado em casos de sucesso e experiências de organizações; e, apresenta menos questionamentos, até pelo fato de ser desenvolvida mais por consultores e pesquisadores focados na prática (GARVIN, 2000, 2002; GARRATT, 1990; PEDLER et al, 1989; de GEUS, 1988; SENGE, 1990).

Embora ambos os conceitos destaquem a aprendizagem individual como ponto de partida de todo o processo, percebe-se a atenção especial de transferir os conhecimentos e competências dos indivíduos e de grupos para a organização, com o propósito de torná-la mais competitiva. Alguns teóricos criticam a limitação na capacidade de contribuição da teoria de aprendizagem individual para a compreensão da aprendizagem organizacional. Fiol e Lyles (1985) destacam no artigo "Organizational Learning" que grande parte da literatura da aprendizagem individual não contribui ou não se aplica de forma direta para o campo da aprendizagem organizacional. Da mesma forma, Weick (1991) corrobora a limitação da contribuição, já que indivíduos e organizações são entidades bem diferentes.

Por outro lado, o estudo sobre aprendizagem organizacional de Crossan et al (1999) enxerga o processo de forma mais completa e integrada. Os autores fornecem uma visão de como a aprendizagem individual transfere-se para grupos e, posteriormente, para a organização. A

\footnotetext{
${ }^{4}$ Os termos utilizados são traduções do inglês "Organizational Learning" e "Learning Organizational", respectivamente, Aprendizagem Organizacional e Organizações de Aprendizagem.
} 
"estrutura unificante" é composta pelo processo que vai do indivíduo à organização: "intuição

$>$ Interpretação > Integração > institucionalização". Mas a principal associação é da consideração do processo de forma dinâmica e que possibilite a retro-alimentação do sistema. Assim, indivíduos e grupos transferem aprendizagem para a organização, mas ao mesmo tempo, a organização alimenta os níveis individual e grupal, influenciando comportamentos e pensamentos das pessoas.

Mesmo assumindo certa ligação com estes conceitos, a finalidade deste estudo é no aprendizado individual e não no organizacional.

Da mesma forma não se pretende trabalhar com competências organizacionais e essenciais (PRAHALAD; HAMEL, 2005) no sentido de orientação estratégica. São apenas tratadas as competências dos indivíduos.

Por conta da natureza da amostra, ex-alunos da FEA-USP, foi desnecessário efetuar um levantamento da educação formal prévia, já que o ponto de partida - a partir da universidade -, é o mesmo para todos. Sabe-se também que todos os formados tiveram que apresentar os mesmos resultados para, primeiro, conseguir ingressar na instituição por conta do processo seletivo da FUVEST, e por fim, concluir seus estudos. Além do mais, o foco deste estudo foi compreender a aprendizagem ocorrida após o término do curso de ensino superior. Mantivemos como foco principal a aprendizagem que resulta em ganho de competência para aumentar o desempenho profissional.

\subsection{Significância do Estudo}

Este estudo é significativo para a pesquisa, as organizações, os indivíduos e as instituições de ensino. Apresentamos as contribuições nesta ordem.

Recentemente nos Estados Unidos, surgiram áreas de HRD (Human Resource Development), ou seja, áreas nas faculdades de Educação que estudam o desenvolvimento do indivíduo dentro das organizações. Ao contrário das áreas de Recursos Humanos, que promovem a 
gestão das pessoas; as áreas de HRD pesquisam a fundo como os profissionais aprendem e se desenvolvem.

No Brasil, há pouquíssimos estudos e todos são de natureza qualitativa. Closs e Antonello (2008) levantaram toda a publicação nacional relevante e identificaram que no tema foram produzidas duas dissertações (MORAES, 2000; GOTTWALD, 2001), seis teses (LUCENA, 2001; CUNHA, 2003; GROHMANN, 2004; ROGLIO, 2006; BITENCOURT, 2006; ANTONELLO, 2004) e dois artigos (SILVA et al, 2006; LEITE et al, 2006) em publicações de revistas "A" Nacional, segundo avaliação da CAPES (Coordenação de Aperfeiçoamento de Pessoal de Nível Superior). Além destes, pudemos levantar: Possamai (2005), Moraes (sd), Moraes et al (2004a), Moraes et al (2004b), Silva (2008) e Correia et al (2008).

É válido lembrar que a Faculdade de Educação da principal universidade brasileira, a USP (Universidade de São Paulo), não possui contribuições nesta área, restringindo-se apenas à pedagogia infantil e licenciatura.

Portanto, para a pesquisa este trabalho representa a primeira publicação quantitativa brasileira de uma área, cuja importância vem crescendo internacionalmente e a produção nacional ainda é muito pequena. Além disso, representa uma fonte para futuros pesquisadores, visto a quantidade de referências levantadas.

Para as organizações, a aprendizagem se torna critério-chave para obter competitividade. Portanto, criar políticas adequadas e aperfeiçoar a eficácia das ações de desenvolvimento, bem como de gestão do conhecimento, contribuem diretamente para o crescimento de seus trabalhadores e, conseqüentemente, num círculo virtuoso, promovem a aprendizagem organizacional.

A capacidade e a velocidade de aprender aumentam os retornos da organização (EHRENBERG; SMITH, 2005), já que indivíduos que aprendem de maneira rápida encurtam prazos de treinamento e aprendem de outras formas vinculadas às tarefas do dia a dia do trabalho, sem custos para a organização. Além disso, estes indivíduos aumentam a produtividade, tomam decisões mais assertivas, não repetem os mesmos erros e buscam a inovação. 
Como a aprendizagem é "um processo que tipicamente contém uma série de ondas" (CHEETHAM; CHIVERS, 2001, p.279) e gradual, os aumentos subseqüentes de salário são muito menores que o aumento da produtividade (BISHOP, 1994; STEVENS, 1994; OECD, 2008b).

Assim, a contribuição para as organizações é ampliar seus benefícios da aprendizagem e otimizar os investimentos em desenvolvimento de pessoas.

Para os indivíduos, este estudo pode auxiliá-los no desenvolvimento de competências profissionais, uma vez que conhecendo como ocorre a aprendizagem e quais são as ações de aprendizagem, é possível colher melhor a oportunidade. Contribui também para a conscientização de que devem ter como valor a vontade em aprender, de que são aprendizes por toda a vida e de que estes devem tomar a dianteira no planejamento, execução e acompanhamento de seus planos de desenvolvimento.

Ademais, indivíduos que aprendem mais rápido escolhem os trabalhos que pagam melhor no mercado, pois estes requerem as suas capacidades (ALTOJI; SPLETZER, 1991). E, a busca pela aprendizagem tem que ser intensa no início da carreira já que cerca de dois terços do crescimento dos salários dos homens ocorrem nos primeiros 10 anos no mercado de trabalho (MURPHY; WELCH, 1990).

Logo, a contribuição para os indivíduos é aprimorar a aprendizagem para que obtenham como conseqüências: aumento de salários, promoções, garantia de empregabilidade e desenvolvimento profissional em geral.

Por fim, as Instituições de Ensino Superior (IES) podem ter insumos para repensar no seu papel. Em nossa opinião, as IES deveriam capacitar seus estudantes na coisa mais importante que elas podem oferecer: aprender a aprender. Com esta competência internalizada, instituição e egressos podem manter seus conhecimentos e habilidades para que não fiquem desatualizados ou vencidos com o decorrer do tempo, esta condição é fundamental para continuar o desenvolvimento neste mundo cada vez mais dinâmico e competitivo. 


\subsection{Organização do Trabalho}

Este trabalho está organizado da seguinte maneira. Na seção dois, algumas teorias sobre aprendizagem são apresentadas e faz-se destaque para a aprendizagem experiencial.

Na seqüência, exploraremos o conceito de aprendizagem para chegar a uma definição a ser utilizada neste trabalho, bem como o do que seja um evento de aprendizagem. Complementamos o assunto da aprendizagem com as características do aprendiz adulto.

Depois, três estruturas de classificação de eventos de aprendizagem são apresentadas e analisadas para que uma nova proposta seja oferecida.

Para complementar, é exposto o conceito de competência individual e são apresentadas e analisadas vinte e oito tipologias de competências. Ao fim, escolhemos uma tipologia para analisar a relação com os eventos de aprendizagem.

$\mathrm{Na}$ terceira seção, apresentamos a metodologia empregada e uma breve descrição das aplicações estatísticas que serão utilizadas na fase de análise. Também, será apresentado o instrumento de pesquisa, assim como seu processo de construção e uma estratégia de coleta.

Na quarta seção, discutimos os resultados decorrentes da análise e verificamos os resultados das hipóteses previamente levantadas, seguidos de um aprofundamento do estudo. Por fim, um resumo dos principais produtos encontrados é apresentado em conjunto com as considerações finais deste estudo.

\subsection{Aspectos Gerais Metodológicos}

Para atingir os objetivos propostos neste trabalho e testar as hipóteses, realizamos uma pesquisa com questionário estruturado e questões fechadas junto aos ex-alunos da FEA-USP que possuem cadastro no Programa de Relacionamento com Ex-Alunos (FEA+). O método de aplicação foi online em ferramenta específica. 
Para o ferramental de análise, fizemos uso principalmente da Análise de Variância (ANOVA) e da Análise de Correspondência (ANACOR). As variáveis para competência e grupos de eventos de aprendizagem são tecidas ao longo da revisão bibliográfica.

O detalhamento do procedimento metodológico será apresentado na parte 3 deste trabalho. 


\section{REVISÃO BIBLIOGRÁFICA}

\subsection{Teorias de Aprendizagem}

No livro Learning in Adulthood, Merriam e Caffarella (1991) reservaram um capítulo para apresentar as principais orientações sobre aprendizagem. $\mathrm{O}$ quadro resumo apresentado na página 138 está presente em inúmeros trabalhos de autores brasileiros e estrangeiros (exemplo: POSSAMAI, 2005; MORAES et al, 2004; SILVA, 2008), pois representa uma ótima referência para percorrer estas teorias. Não diferente dos demais, apresentaremos o quadro e na seqüência uma breve explanação das teorias.

\begin{tabular}{|c|c|c|c|c|}
\hline Aspecto & Behaviorista & Cognitivista & Humanista & Social Learning \\
\hline $\begin{array}{l}\text { Teóricos da } \\
\text { aprendizagem }\end{array}$ & $\begin{array}{l}\text { Thorndike, Pavlov, } \\
\text { Watson, Guthrie, } \\
\text { Hull, Tolman, } \\
\text { Skinner }\end{array}$ & $\begin{array}{l}\text { Koffka, Kohler, } \\
\text { Lewin, Piaget, } \\
\text { Ausubel, Bruner, } \\
\text { Gagne }\end{array}$ & Maslow, Rogers & Bandura, Rotter \\
\hline $\begin{array}{l}\text { Visão do processo } \\
\text { de aprendizagem }\end{array}$ & $\begin{array}{l}\text { Mudança de } \\
\text { comportamento }\end{array}$ & $\begin{array}{l}\text { Processo mental } \\
\text { interno (incluí: } \\
\text { insight }{ }^{5} \text {, } \\
\text { processamento da } \\
\text { informação, } \\
\text { memória, } \\
\text { percepção) }\end{array}$ & $\begin{array}{l}\text { Um ato pessoal } \\
\text { para atender uma } \\
\text { potencialidade }\end{array}$ & $\begin{array}{l}\text { Interação e } \\
\text { observação de } \\
\text { outros num } \\
\text { contexto social }\end{array}$ \\
\hline $\begin{array}{l}\text { Locus }^{6} \mathrm{da} \\
\text { aprendizagem }\end{array}$ & $\begin{array}{l}\text { Stimuli }{ }^{7} \text { no } \\
\text { ambiente externo }\end{array}$ & $\begin{array}{l}\text { Estruturação } \\
\text { cognitiva interna }\end{array}$ & $\begin{array}{l}\text { Demandas } \\
\text { cognitivas e afetivas }\end{array}$ & $\begin{array}{l}\text { Interação de } \\
\text { pessoa, } \\
\text { comportamento e } \\
\text { ambiente }\end{array}$ \\
\hline $\begin{array}{l}\text { Propósito da } \\
\text { educação }\end{array}$ & $\begin{array}{l}\text { Produzir mudança } \\
\text { de comportamento } \\
\text { na direção desejada }\end{array}$ & $\begin{array}{l}\text { Desenvolver } \\
\text { capacidade e } \\
\text { habilidades para } \\
\text { aprender melhor }\end{array}$ & $\begin{array}{l}\text { Tornar-se uma } \\
\text { pessoa auto- } \\
\text { atualizada, } \\
\text { independente }\end{array}$ & $\begin{array}{l}\text { Modelar novos } \\
\text { papéis e } \\
\text { comportamentos }\end{array}$ \\
\hline Papel do professor & $\begin{array}{l}\text { Preparar o } \\
\text { ambiente para } \\
\text { extrair a resposta } \\
\text { desejada }\end{array}$ & $\begin{array}{l}\text { Estruturar o } \\
\text { conteúdo da } \\
\text { atividade de } \\
\text { aprendizagem } \\
\end{array}$ & $\begin{array}{l}\text { Facilitar } \\
\text { desenvolvimento } \\
\text { da pessoa como um } \\
\text { todo }\end{array}$ & $\begin{array}{l}\text { Modelar e guiar } \\
\text { novos papéis e } \\
\text { comportamentos }\end{array}$ \\
\hline $\begin{array}{l}\text { Manifestação na } \\
\text { aprendizagem do }\end{array}$ & $\begin{array}{l}\text { Objetivos } \\
\text { comportamentais }\end{array}$ & $\begin{array}{l}\text { Desenvolvimento } \\
\text { cognitivo }\end{array}$ & $\begin{array}{l}\text { Andragogia } \\
\text { Self-directed }\end{array}$ & $\begin{array}{l}\text { Socialização } \\
\text { Papéis sociais }\end{array}$ \\
\hline
\end{tabular}

\footnotetext{
${ }^{5}$ A melhor tradução da palavra "insight" que é apropriada neste caso é: a visão do interior de algo. Outras traduções da mesma palavra são: discernimento, dedução e percepção; ou mesmo, a ação ou o resultado de compreender a natureza intrínseca das coisas. Preferiu-se neste caso manter o termo inglês, pois o mesmo é recorrentemente utilizado no Brasil.

6 "Locus" é uma palavra em latim que significa centro de atividade.

7 "Stimuli" é o plural de stimulus que em latim significa estímulo; algo que impacta ou influencia em um sistema.
} 


\begin{tabular}{|l|l|l|l|l|}
\hline adulto & Educação baseada & Inteligência, & learning & Mentoring \\
na competência & aprendizagem e & & Locus de controle \\
& $\begin{array}{l}\text { Desenvolvimento } \\
\text { de habilidade e } \\
\text { treinamento }\end{array}$ & $\begin{array}{l}\text { função da idade } \\
\text { Aprender como } \\
\text { aprender }\end{array}$ & & \\
& & & \\
\hline
\end{tabular}

Quadro 1 - Teorias de aprendizagem. Fonte: MERRIAM \& CAFFARELLA (1991, p. 134)

O behaviorismo foi criado por John B. Watson no início do século XX e os estudos desta orientação focam os comportamentos observáveis, em detrimento do pensamento. Além disso, a mudança de comportamento é o que define a aprendizagem. Outras duas características são destacadas nesta corrente: Primeiro, o que alguém aprende é determinado pelo ambiente e não pelo indivíduo em si, em outras palavras, o ambiente molda o comportamento; e, a continuidade e o reforço são essenciais para explicar o processo de aprendizagem. Ou seja, ao aumentar a frequência e o estímulo da repetição dos eventos, a aprendizagem é mais factível de ocorrer.

Um dos personagens mais conhecidos desta teoria é o cachorro de Pavlov, pois muitas pesquisas behavioristas usavam animais em seus experimentos. As pesquisas sobre a salivação de seu cachorro - que não estava atrelada apenas ao ver a comida, mas sim com alguma associação (gesto ou som) à chegada da comida -, levaram ao Prêmio Nobel de 1904 pela sua contribuição à pesquisa digestiva de cães. Ivan Pavlov aprofundou os estudos de Thorndike sobre as conexões entre impressões sensoriais ou stimuli (S) e comportamento conseqüente ou respostas $(\mathrm{R})$.

Como exemplo de teorias que são pertinentes até hoje temos o condicionamento operante do professor da Harvard University, Burrhus Frederic Skinner, no qual o reforço positivo e a recompensa de determinados comportamentos estimulam a sua repetição, enquanto que o reforço negativo ou mesmo a ausência de reforço tende a inibir a ocorrência de determinado comportamento.

Nas organizações o behaviorismo é exemplificado tanto pelas relações entre os gestores e seus subordinados, que estimulam ou coíbem certos comportamentos, quanto na criação de políticas da área de recursos humanos para promover o esforço e superação de metas.

Entretanto, 


\begin{abstract}
"A mente humana não é apenas um sistema terminal de trocas passivo, no qual o stimuli chega e a resposta apropriada parte. Pelo contrário, o pensamento da pessoa interpreta sensações e dá significado aos eventos que infringem a sua consciência". (GRIPPEN; PETERS, 1984, p.76 apud MERRIAM; CAFFARELLA, 1991)
\end{abstract}

Assim como estes autores, os psicólogos da Gestalt criticavam o behaviorismo por ser muito particular, muito preocupado com eventos e ações simples e depender do comportamento público para explicar a aprendizagem. A diferença entre estas duas orientações é de que enquanto o behaviorismo aponta o locus de controle no ambiente, o cognitivismo o retoma para o indivíduo.

Outro ponto que caracteriza o cognitivismo é a visão da aprendizagem como processamento da informação na mente humana. Deste modo, seus estudos tinham como temas a percepção, o insight, a metacognição, a memória e o processo mental do aprendiz. As contribuições desta teoria potencializaram a compreensão da forma de aprender das pessoas ("learning how to learn"), aprimoraram teorias de transferência de conhecimento, de tomada de decisão e de resolução de problemas e, semearam o campo para o desenvolvimento da inteligência artificial.

Robert Mills Gagné (1965) identificou as condições mentais de aprendizagem e é reconhecido pela sua contribuição na abordagem sistêmica para o design instrucional e treinamento. Como exemplo de sua contribuição, temos os nove eventos instrucionais que orientam professores e instrutores a estimularem os alunos a aprenderem: 1) obter atenção; 2) informar os objetivos de aprendizagem; 3) Estimular a recuperação aprendizagem prévia; 4) o conteúdo deve ser apresentado de forma organizada, clara e significativa; 5) Prover orientação adicional (exemplos, casos, representação gráfica etc.) para garantir a fixação; 6) Garantir a aprendizagem por meio da execução; 7) Prover feedback; 8) Avaliar o desempenho; e, 9) Aumentar retenção e transferência.

Além disso, Gagné (1965) foi responsável por definir as cinco categorias dos resultados ou objetivos de aprendizagem: informação verbal; habilidade intelectual; estratégias cognitivas; atitudes; e, habilidades motoras.

Diferentemente destas duas primeiras orientações, a corrente humanista considerava a aprendizagem a partir da perspectiva do potencial humano para o crescimento. Assim, não se 
convenciam pela influência do ambiente no comportamento provinda dos behavioristas, tampouco pelas teorias sobre a influência da subconsciência no comportamento humano desenvolvidas pelo psicanalista Sigmund Freud.

Dentre os teóricos humanistas destacam-se dois em especial: Abraham Maslow e Carl Rogers. O primeiro, considerado o fundador desta teoria, ficou conhecido por meio de seus estudos sobre motivação baseada na hierarquia das necessidades, na qual o indivíduo tem uma série de necessidades (a saber: básicas (fome e sede), segurança, pertencimento e amor, autoestima) antes de poder ir à busca de sua autorrealização. Conforme a pessoa busca a sua autorrealização, aumentam a necessidade de conhecimento e o desejo de conhecer e de compreender, ou seja, sua meta é a aprendizagem.

Rogers, por sua vez, escreveu um dos livros clássicos da aprendizagem, o "Freedom to Learn" (1980), no qual a aprendizagem, focando a atenção no aprendiz, pode levar ao crescimento e desenvolvimento pessoal. A aprendizagem tem a característica de contar com o:

- envolvimento do aprendiz tanto no emotivo, quanto no cognitivo;

- auto-iniciativa do aprendiz (o senso de descobrimento deve vir de dentro);

- ser penetrante (aprendizagem modifica o comportamento, as atitudes e talvez até mesmo a personalidade do aprendiz)

- poder ser avaliado pelo aprendiz;

- a aprendizagem experiencial ocorre e o seu significado é incorporado pela experiência total do indivíduo.

As contribuições de Maslow e Rogers foram incorporadas pelos conceitos de aprendizagem de adultos e estão presentes nas teorias de Knwoles $(1968 ; 1975 ; 1980)$ sobre andragogia e de Gugliermino (1977) sobre Self-Directed Learning.

Os estudos sobre como as pessoas aprendem por meio da observação já ocorriam na década de 1940 por Miller e Dollard, entretanto foi com Bandura $(1977$; 1986) que a orientação da aprendizagem social se destacou da behaviorista. Bandura focou seus estudos no processo cognitivo ocorrido no ato da observação e não no comportamento subseqüente. 
As pessoas podem aprender observando sem necessariamente imitar o que está sendo observado. Por exemplo, as pessoas podem até certo ponto regular seu próprio comportamento visualizando o comportamento dos outros e suas conseqüências para os mesmos.

Assim como Bandura, Rotter desenvolveu a teoria de que "muito do comportamento humano ocorre em um ambiente significativo e é adquirido por meio das interações sociais com outras pessoas" (PHARES, 1980, p.406, apud MERRIAM; CAFFARELLA, 1991).

Da orientação da aprendizagem social temos muitos conceitos que são relevantes na aprendizagem de adultos. Como exemplo, temos a importância do contexto, da interação do aprendiz com o ambiente e da interação com os outros, o conceito de locus de controle e as bases que formam a aquisição de conhecimento social e o mentoring.

É pertinente mencionar que na segunda versão do mesmo livro, lançada em 1999, os autores reformularam o quadro e adicionaram mais uma teoria: a Construtivista ${ }^{8}$. Esta teoria foi desenvolvida principalmente por Candy, Dewey, Lave, Piaget, von Glaserfield e Vigotsky, e considera a aprendizagem como sendo uma construção interna do significado da experiência pelo indivíduo. Traços desta orientação podem ser encontrados nas teorias de aprendizagem experiencial (KOLB, 1984; MARSICK; WATKINS, 1990), aprendizagem situada (LAVE; WENGER, 1991) e aprendizagem transformacional (MEZIROW, 1994).

Por conta da importância da aprendizagem experiencial para este trabalho, apresentá-la-emos a seguir.

\subsubsection{Aprendizagem Experiencial}

Aprendendo pela experiência é compreendido pelas autoras Marsick e Watkins (1990) como sendo "o meio pelo qual as pessoas fazem sentido das situações que elas encontram em suas vidas diárias". Para esclarecer este ponto, as autoras utilizam o provérbio "A natureza é a professora mais difícil. Primeiro ela dá o teste e depois a aula”. Assim, as pessoas estão

\footnotetext{
${ }^{8}$ Como não foi possível encontrar o livro com a fonte mais atual, preferiu-se apresentar o que havia disponível.
} 
preocupadas em como extrair estas "aulas" para que o "teste" seja absorvido e que não cometam novamente o mesmo erro.

A definição comumente utilizada é a de Kolb (1984), em que "aprendizagem é o processo pelo qual conhecimento é criado através da transformação da experiência”. Shapiro (1994) analisa esta definição e aponta três aspectos críticos da aprendizagem vista a partir da perspectiva experiencial.

\begin{abstract}
"Primeiro, a ênfase é no processo de adaptação e aprendizagem e não no conteúdo ou resultados. Segundo, o conhecimento é um processo de transformação, sendo continuamente criado e recriado, e não uma entidade independente para ser adquirida ou transmitida. Terceiro, a aprendizagem transforma a experiência tanto em sua forma objetiva, quanto subjetiva. Finalmente, para compreender aprendizagem nós devemos entender a natureza do conhecimento e vice-versa." (ibid., p.38-39)
\end{abstract}

Para Jarvis (1987, p.164) a "aprendizagem é a transformação da experiência em conhecimento, habilidades e atitudes". Para o autor a aprendizagem sempre começa com alguma experiência e o processo de aprendizagem é a transformação disso. A vida é experiência, logo aonde houver vida há potencial de experiências de aprendizagem.

Comparando a definição de Kolb (1984) com a de Jarvis (1987), notamos que o primeiro apresenta o conhecimento como sendo o único resultado da aprendizagem, enquanto que o segundo levanta outros resultados. Assim, o resultado da aprendizagem poderia ser uma pessoa mais experiente que tem novo conhecimento, novas habilidades, diferentes atitudes, ou mudança de autoconceito.

Já para Cell (1984, p.60), a aprendizagem experiencial "ocorre quando a interação direta com nosso mundo ou com nós mesmos resulta em mudança de comportamento, interpretação, autonomia e criatividade”. Para o autor há quatro tipos de aprendizagem experiencial:

- aprendizagem resposta (response learning): é a mudança na maneira em que nós desenvolvemos novas respostas a certas situações;

- aprendizagem situacional: é a mudança em como nós interpretamos um certo tipo de situação;

- aprendizagem transsituacional: é como nós aprendemos a mudar nossa interpretação de uma situação; 
- aprendizagem transcendental: é o desenvolvimento da capacidade para modificar ou criar novos conceitos para interpretação de situações individuais.

\subsubsection{Ciclo de Aprendizagem de Kolb}

Kolb (1984) é o principal teórico presente nos trabalhos de aprendizagem experiencial e sua "teoria [...] do ciclo de aprendizagem é de longe a mais citada" (HENRY, 1989, p.27).

A teoria de aprendizagem experiencial de Kolb (op.cit.) foi desenvolvida a partir de estudos de Jean Piaget (1952), Paulo Freire (1970) e de William James (1977). Nestes autores podemos encontrar visões similares, porém distintas sobre a integração dos dialéticos trabalhados por Kolb (MAINEMELIS et al, 2002).

A aprendizagem experiencial é concebida de um ciclo em quatro estágios. A experiência concreta imediata é a base para a observação e reflexão, que por sua vez são assimiladas em teorias pelas quais novas implicações para a ação podem ser deduzidas. Estas implicações e hipóteses servem então como guias na ação para se criar novas experiências (KOLB, 1976).

Segundo Kolb (1984), o modelo de aprendizagem experiencial apresenta duas dimensões dialéticas que correspondem diretamente aos aspectos figurativos e operativos de Piaget (1970). A primeira dialética versa sobre a oposição nos modos de preensão da experiência, ou de se apoderar de uma experiência, que pode ser por meio da compreensão - interpretação conceitual e representação simbólica -, ou por apreensão - pautado no tangível, qualidades sentidas da experiência imediata. Em outras palavras, podemos aproveitar a experiência por meio da Conceitualização Abstrata (Abstract Conceptualization, AC) e da Experiência Concreta (Concrete Experience, $\mathrm{CE}$ ).

A segunda dialética versa sobre as maneiras opostas de transformar esta preensão, que pode ser via a reflexão interna que Kolb chama de intenção, ou via a manipulação externa ativa, denominada extensão. Em outras palavras, a transformação da experiência pode ser via Observação Reflexiva (Reflective Observation, RO) e Experimentação Ativa (Active Experimentation, AE). 
"Aprendizagem é um processo pelo qual o conhecimento é criado por meio da transformação da experiência. Conhecimento resulta da combinação do aproveitamento da experiência e da transformação disto" (KOLB, op.cit., p.41).

Tomando esta definição e sabendo que o conhecimento pode resultar de 4 combinações distinta, a figura abaixo apresenta o modelo de Kolb:

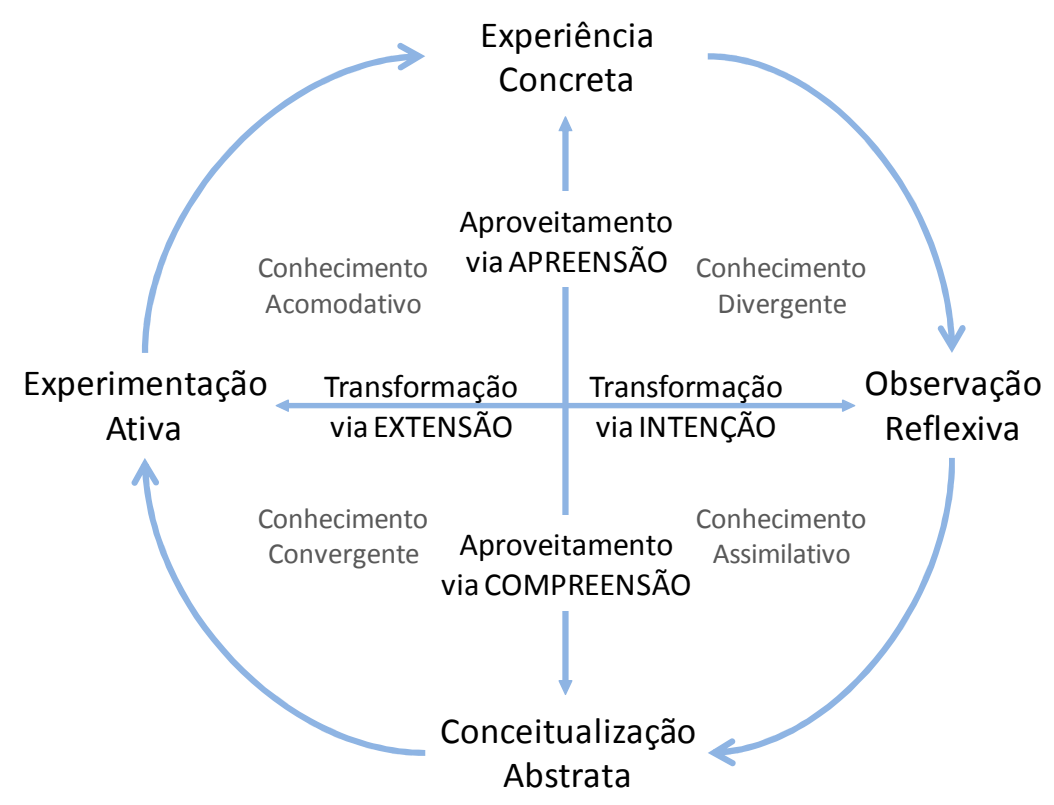

Figura 1 - Dimensões estruturais que suportam o processo de aprendizagem experiencial e as formas de conhecimento resultantes (fonte: Ibid., p.42)

Experiência aproveitada via apreensão e transformada via intenção resulta no conhecimento divergente. Experiência aproveitada via compreensão e transformada via intenção resulta no conhecimento assimilativo. Novamente, quando a experiência é aproveitada via apreensão e transformada via extensão, temos o conhecimento acomodativo. Por fim, a experiência é aproveitada via compreensão e transformada via extensão, temos o conhecimento divergente.

Desta combinação, Kolb $(1976,1984)$ também desenvolveu o Learning Style Inventory (LSI), uma ferramenta para medir a intensidade das diferentes aptidões pelos quais as pessoas aprendem e resolvem problemas. A seguir apresentamos os resultados possíveis:

- Convergente (AC-AE): a grande habilidade de quem possui este estilo é a capacidade prática de aplicação das ideias. As pessoas deste tipo preferem lidar com coisas a lidar 
com pessoas, e tendem a possuir um interesse por assuntos técnicos específicos ou a se especializar em ciências físicas. Muitos engenheiros possuem este estilo de aprendizagem.

- Divergente (CE-RO): é o oposto do convergente. Sua grande habilidade é a imaginação e a capacidade de enxergar situações concretas por muitas perspectivas. As pessoas deste estilo são mais interessadas nas pessoas e são mais emotivas. É um estilo comum para os gestores com background em humanidades.

- Assimilador (AC-RO): possui a habilidade de criar modelos teóricos. É menos interessado em pessoas e mais preocupado em conceitos teóricos, mas são menos práticos com o uso destas teorias. Este estilo é mais comum aos pesquisadores e pessoas que trabalham nos departamentos de planejamento.

- Adaptador (CE-AE): possui as habilidades opostas do assimilador. Sobressai-se em atividades práticas, em conduzir projetos e se envolver em novas experiências. A pessoa deste estilo tende a ser mais tomador de risco e mais adaptativo, e nos momentos de turbulência desconsidera os conceitos e age de maneira própria. É o estilo comum dos gestores que lidam com a prática, como os de marketing e vendas.

Como conclusões do uso do LSI em pesquisas, temos, por exemplo, que o desencontro entre o estilo de aprendizagem do indivíduo com as normas de aprendizagens do campo, fazem com seja mais provável que a pessoa mude ou deixe o campo. Isto foi comprovado por Plovnick (1971 apud Kolb, 1976), já que o estilo convergente era predominante entre os alunos de física e os demais estudantes do estilo divergente, encontravam-se indecisos sobre a carreira e buscavam mais disciplinas fora da grade de física.

Entretanto, é válido lembrar que Wolfe (1977) citado por Mainemelis et al (2002) comprova que em simuladores de negócios, times com estilos balanceados obtêm desempenho significativamente superior aos times com estilos de aprendizagem especializados.

Um último ponto sobre o assunto é que os gestores em geral possuem forte habilidade de experimentação ativa, entretanto são fracos na habilidade de observação reflexiva. Já os docentes das escolas de negócios possuem geralmente o perfil oposto (KOLB, 1976). Quando "uma perspectiva domina a outra, a aprendizagem é reduzida no longo prazo. A partir daí concluímos que os sistemas mais eficazes de aprendizagem são aquele que podem tolerar diferenças de perspectiva" (Ibid., p.30). 


\subsection{Aprendizagem}

\subsubsection{Produto ou Processo}

A aprendizagem pode ser vista como um produto ou como um processo. Sfard (1998) explica as diferentes visões entre as formas por meio de duas metáforas.

A primeira metáfora, "aprendizagem como obtenção" (learning as attainment), apresenta a aprendizagem como um produto e procura entregar ao empregado habilidades e conhecimentos geralmente por meio de cursos e treinamentos fora do trabalho.

Nesta abordagem, a grande contribuição foi o desenvolvimento de qualificações vocacionais baseadas em competências, os quais privilegiam a avaliação dos resultados da aprendizagem. Entretanto, o processo de transferência de habilidades e conhecimentos tende a ser tratado como algo sem problema, pois se acredita que as habilidades e conhecimentos já estão bem definidos e bem codificados.

A outra metáfora, "aprendizagem como participação" (learning as participation), mostra a aprendizagem como um processo e busca entender como as pessoas aprendem no trabalho. A grande característica é que nesta metáfora considera-se que diferentes ambientes de trabalhos proporcionam uma gama de oportunidades distintas para as pessoas participarem e aprenderem. Deste ponto decorrem os três motivos que justificam a utilização neste trabalho da aprendizagem como processo.

Primeiro, esta metáfora legitima o ambiente de trabalho como sendo uma fonte e um lugar para ensinar e aprender. Assim, as ações de aprendizagem formais deixam de ganhar todo o foco das atenções.

Segundo, concebe a aprendizagem como sendo fundamentalmente social e situada (LAVE; WENGER, 1991), deste modo as pessoas aprendem no trabalho de maneira natural, um ajudando o outro, e desempenhando tarefas e tendo experiências. 
Terceiro, compreendendo a aprendizagem dependente do contexto, situada e com atividades sociais, é impossível atribuir a mesma facilidade na transferência como na outra metáfora, logo os estudos no processo em si são fundamentais.

Logo, aprendizagem como processo e não como produto enfatiza o "que acontece" e "onde a aprendizagem ocorre".

\subsubsection{Definição de Aprendizagem}

A relação entre aprendizagem e trabalho é um tópico "sem uma casa estabelecida" (BECKETT; HAGER, 2002) e um conceito que possui "polissemia" (SALVADOR, 1994). Por isso, "não possui uma significação única" (ABBAD; MOURÃO, 2006); é "pouco compreendida e teorizada" (FULLER et al, 2003, p.14); e, na prática, "não há consenso" (ABBAD; BORGES-ANDRADE, 2004) e "seu uso é pouco crítico" (COELHO Jr.; BORGES-ANDRADE, 2008).

Por conta disso, faz-se necessário analisar os estudos e conceitos a cerca do tema para encontrar uma definição pertinente com os objetivos deste trabalho.

Coelho Jr. \& Borges-Andrade (ibid., p.224) analisaram o termo aprendizagem por meio de técnicas de análise conceitual propostas por Ryle (1970). Na primeira parte do trabalho, os autores identificaram os principais usos do conceito de aprendizagem na linguagem cotidiana, investigando alguns trabalhos (AUSUBEL et al, 1983; SALVADOR, 1994) e consultando dicionários de língua portuguesa (AULETE, 2004; FERREIRA, 1999). Os achados encontram-se abaixo:

1. ação de reter algo, de fixar algo na memória, qualquer ofício, arte, ciência ou uma profissão (saber como, tornar-se capaz de);

2. ato, processo ou efeito de obter conhecimento por meio de escolarização/estudo, ficar sabendo (de algo com alguma finalidade);

3. aprender algo ou alguma coisa (conhecimento ou habilidade) por meio de escolarização e estudo, instruir-se em e instruir-se para;

4. adquirir habilidade prática (em aprender um esporte); 
5. conhecimento ou habilidade obtido por meio de treino e/ou estudo, aplicada a principiantes em torno da aquisição de algo;

6. reter algo na memória, esforço deliberado para se obter conhecimento sobre algo e que se relaciona à vontade de aprender;

7. vivência, carga afetiva e de sensibilidade "aprendeu com a vida" (COELHO Jr. \& BORGES-ANDRADE, 2008, p.224; negrito nosso).

Analisando estes usos, notamos ênfase para os métodos tradicionais de aprendizagem e para o sentido de adquirir (obter) e reter (fixar) conhecimentos e habilidades.

$\mathrm{Na}$ análise conceitual propriamente dita, os autores identificaram que: "o conceito de aprendizagem remete a um verbo adverbial (aprender), disposicional aberto, relacionado ou não à ocorrência de uma situação episódica ou situacional, intrínseco ou extrínseco e com duas polaridades" (ibid., p.226).

Para facilitar a interpretação, explicaremos no quadro abaixo o significado de cada um dos achados.

\begin{tabular}{|l|l|}
\hline Característica & Explicação \\
\hline Verbo adverbial & $\begin{array}{l}\text { Representa uma descrição incompleta de algo, logo há necessidade de } \\
\text { ser complementado }\end{array}$ \\
\hline Disposicional aberto & $\begin{array}{l}\text { Aprendizados passados são combinados com novos adquiridos para } \\
\text { facilitar a sua aquisição, retenção e aplicação, além de construir novos } \\
\text { significados }\end{array}$ \\
\hline $\begin{array}{l}\text { Relacionado ou não à } \\
\text { ocorrência de uma } \\
\text { situação episódica ou } \\
\text { situacional }\end{array}$ & $\begin{array}{l}\text { Pode-se "aprender como/a" (relacionado a uma ocorrência episódica ou } \\
\text { situacional. Ex.: aprender como conquistar clientes) e "aprender que" } \\
\text { (elemento informacional. Ex.: aprender que o processo funciona desta } \\
\text { forma) }\end{array}$ \\
\hline $\begin{array}{l}\text { Intrínseco ou } \\
\text { extrínseco }\end{array}$ & $\begin{array}{l}\text { Intrínseca é a aprendizagem contextualizada à realidade e interesse dos } \\
\text { indivíduos (aprender a desempenhar um novo trabalho); extrínseca é a } \\
\text { aprendizagem impessoal e externa aos indivíduos (aprender normas da } \\
\text { organização) }\end{array}$ \\
\hline Com duas polaridades & $\begin{array}{l}\text { Existe o significado contrário, ou seja, aprendizagem e ausência de } \\
\text { aprendizagem }\end{array}$ \\
\hline
\end{tabular}

Quadro 2 - Características obtidas da análise conceitual. Fonte: próprio autor, analisando ibid. 
Para complementar esta seção do trabalho, apresentaremos algumas das diversas definições encontradas de aprendizagem. Cada uma está conectada com a teoria de que o autor pertence. Abaixo, o quadro as reúne:

\begin{tabular}{|c|c|}
\hline Autor & Definição \\
\hline $\begin{array}{l}\text { Houle }(1980, \\
\text { p.xi). }\end{array}$ & $\begin{array}{l}\text { "Aprendizagem é o processo pelo qual as pessoas obtêm conhecimento, } \\
\text { sensibilidade e domínio de habilidades por meio de experiência ou estudo" }\end{array}$ \\
\hline $\begin{array}{l}\text { Hergenhahn, } \\
\text { 1988, p.7). }\end{array}$ & $\begin{array}{l}\text { "Aprendizagem é uma mudança relativamente permanente no comportamento, } \\
\text { ou na potencialidade comportamental, que resulta da experiência e não pode ser } \\
\text { atribuída a estados corporais temporários, como aqueles induzidos por doenças, } \\
\text { fadiga e drogas" }\end{array}$ \\
\hline $\begin{array}{l}\text { Merriam \& } \\
\text { Caffarella } \\
\text { (1991, p. } \\
\text { 129), citando } \\
\text { os } \\
\text { cognitivistas }\end{array}$ & $\begin{array}{l}\text { "Aprendizagem envolve a reorganização das experiências em ordem a dar } \\
\text { sentido ao stimuli do ambiente" }\end{array}$ \\
\hline $\begin{array}{l}\text { Mezirow } \\
(1991, \text { p.12) }\end{array}$ & $\begin{array}{l}\text { "Aprendizagem pode ser compreendida como o processo de utilizar uma } \\
\text { interpretação prévia para construir uma interpretação nova ou revisada do } \\
\text { significado da experiência do indivíduo com o objetivo de nortear a ação } \\
\text { futura" }\end{array}$ \\
\hline $\begin{array}{l}\text { Kolb }(1984, \\
\text { p.41) }\end{array}$ & $\begin{array}{l}\text { "Aprendizagem é um processo pelo qual o conhecimento é criado por meio da } \\
\text { transformação da experiência. Conhecimento resulta da combinação do } \\
\text { aproveitamento da experiência e da transformação disto" }\end{array}$ \\
\hline Jarvis (1987) & $\begin{array}{l}\text { "Aprendizagem é a transformação da experiência em conhecimento, } \\
\text { habilidades e atitudes" (p.164) }\end{array}$ \\
\hline Cell (1984) & $\begin{array}{l}\text { "Aprendizagem ocorre quando a interação direta com nosso mundo ou com nós } \\
\text { mesmos resulta em mudança de comportamento, interpretação, autonomia e } \\
\text { criatividade" }\end{array}$ \\
\hline $\begin{array}{l}\text { ISCED } \\
(1997, \mathrm{p} .4)\end{array}$ & $\begin{array}{l}\text { "qualquer melhoria no comportamento, informação, conhecimento, } \\
\text { compreensão, atitude, valores ou habilidades" }\end{array}$ \\
\hline
\end{tabular}

Analisando em conjunto as definições, temos uma visão mais ampla da visão de uso cotidiano encontrada anteriormente de aprendizagem com o sentido de adquirir (obter) e reter (fixar) conhecimentos e habilidades por meios tradicionais. Logo, aprendizagem é um processo 
potencial e dinâmico que envolve mudança, reorganização e transformação de experiências, informações e stimuli em conhecimentos, habilidades, atitudes, valores e interpretações para nortear a ação futura.

\subsubsection{Níveis de Profundidade}

$\mathrm{Na}$ literatura pesquisada foi possível identificar autores que apresentavam a aprendizagem em níveis distintos de impactos. Abaixo, as ideias de quatro autores levantados.

Marton et al (1984) distinguem em dois níveis distintos, a aprendizagem superficial e aprendizagem profunda. O primeiro está conectado com as ideias behavioristas, já que se baseia simplesmente no processo de copiar e repetir, enquanto que o outro está baseado no processo cognitivo, pois investiga e busca dar sentido aos conceitos e princípios fundamentais, os quais são necessários para se permitir a conexão entre ideias, conhecimentos e prática.

Engeström (1994) aprimorou os conceitos de 3 níveis de Bateson (1972) e definiu-os como sendo a aprendizagem de primeira, segunda e terceira ordem. A aprendizagem de primeira ordem também está baseada nas ideias behavioristas de aprender de maneira condicionada e por meio da imitação. A aprendizagem de segunda ordem já se utiliza de noções cognitivas de aprender por meio da investigação e da internalização, segundo o autor "o aprendiz constrói a teoria do fenômeno em estudo" (ibid., p. 17). Posteriormente, Engeström (2001) desenvolveu a terceira e última ordem para abranger a aprendizagem transformativa ou expansiva, na qual a aprendizagem é alcançada quando indivíduos, geralmente de diferentes backgrounds, trabalham juntos para criar uma solução original para os problemas do trabalho.

Argyris (1999) desenvolveu os circuitos de aprendizagem. O primeiro, o single loop learning, ocorre quando o indivíduo aprende a corrigir desvios ou erros sem questionar o porquê do erro acontecer. O double loop learning ocorre quando os pressupostos e as normas são questionadas pelos indivíduos, por exemplo, um empregado não apenas aprende a tomar providências quando alguma máquina quebra, mas também passa a buscar soluções para que os fatores que ocasionam a quebra não se repitam, ou mesmo promovendo alterações no 
procedimento de consertos. Por fim, no triple loop learning, a pessoa reflete sobre seu próprio processo de aprendizagem, ou seja, passa a aprender a aprender.

Uma outra forma de abordar a profundidade também pode ser encontrada na taxonomia de Bloom (1956). Antes é necessário compreender os três domínios dos objetivos educacionais ou objetivos de aprendizagem:

- Afetivo: como as pessoas reagem emocionalmente e lidam com os sentimentos;

- Físico-motor: são as habilidades físicas e a coordenação motora;

- Cognitivo: envolve o conhecimento e o desenvolvimento de habilidades intelectuais.

Bloom (1956) detalhou os níveis dos domínios afetivos e do cognitivo. Outros autores elaboraram os níveis do físico-motor, por exemplo, Simpson (1972). Abaixo apresentaremos os respectivos níveis, começando com os mais simples e terminando com os mais complexos:

- Afetivo: recepção, resposta, valorização, organização e internalização dos valores;

- Físico-motor: percepção, prontidão a agir, execução orientada, mecanização, execução de resposta complexa, adaptação e criação (ibid.).

- Cognitivo: conhecimento, compreensão, aplicação, análise, síntese e avaliação.

Como exemplo de leitura da relação anterior, basta pensar que memorizar novos conceitos (conhecimento) é menos complexo do que corrigir uma prova (avaliação), por exemplo. Ou, ainda, só é possível aplicar o que foi compreendido.

No domínio cognitivo, a estrutura foi revisada por Anderson \& Krathwohl (2001) e passou a ser mais utilizada hoje em dia. A diferença principal é que o nível "Síntese" trocou de lugar com "Avaliação" e passou a se chamar "Criar", visto que é um processo mais difícil do que avaliar. Outras mudanças são que os substantivos foram substituídos por verbos e "Conhecimento" passou a se chamar "Lembrar". Abaixo o gráfico apresenta o modelo revisado: 


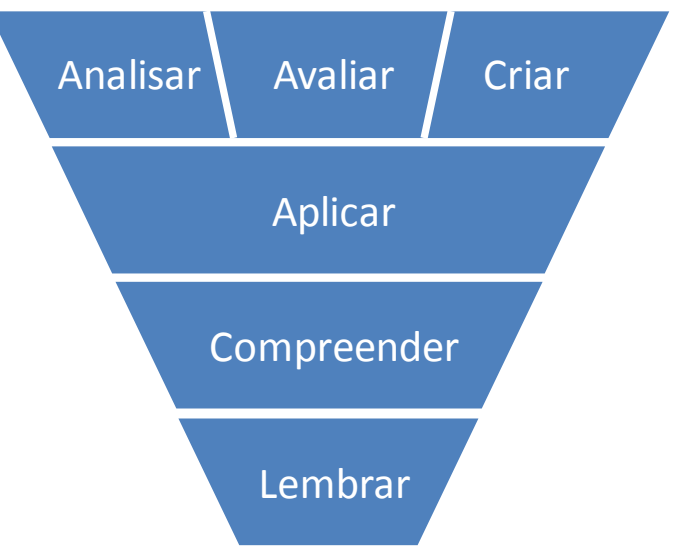

Figura 2 - Dimensão cognitiva da taxonomia de Bloom revisada por Ibid.

Além destes, há também os quatro tipos - que não deixam de ser níveis de profundidade -, de aprendizagem experiencial apresentados por Cell (1984), vistos anteriormente.

\subsection{Evento de Aprendizagem}

$\mathrm{Na}$ literatura, encontramos inúmeras variações similares para o termo "evento de aprendizagem", como, por exemplo, episódio de aprendizagem, atividade de aprendizagem, ação de aprendizagem, oportunidade de aprendizagem, experiência de aprendizagem, entre outros. Embora maioria dos autores use os termos sem defini-los primeiro, encontramos algumas definições para promover uma discussão sobre o tema.

A definição mais antiga foi proposta por Tough (1979), na qual um episódio de aprendizagem é "um período de tempo que é dedicado a um conjunto de seqüência de atividades similares ou relacionadas, no qual mais da metade da intenção da pessoa é obter e reter certo conhecimento e habilidade definido".

Heap (1996, p.10) nomeia o evento de aprendizagem como sendo "qualquer experiência planejada e gerenciada que ajuda os envolvidos a aprenderem novos conhecimentos, habilidades, atitudes e comportamentos".

Já o Classification of Learning Activities (CLA) define uma atividade de aprendizagem como sendo "qualquer atividade organizada de um indivíduo com a intenção de aprimorar o seu conhecimento, habilidade ou competência” (EUROSTAT, 2006, p.9). 
Destas definições vistas é importante dar atenção aos dois critérios que as permeiam: a intencionalidade e a organização da atividade.

No primeiro critério a atividade deve ser intencional (ao contrário da aprendizagem casual), então o ato tem um propósito pré-determinado.

No segundo critério, a atividade é organizada de alguma forma, inclusive pode ser organizada pelo próprio aprendiz. Algumas atividades podem ter um alto nível de organização como, por exemplo, uma aula expositiva; já outras podem ter um baixo nível de organização como, por exemplo, a autoaprendizagem de um software, usando o próprio manual. Assim, todas as ações têm certo nível de organização.

A título de curiosidade, uma Atividade de Aprendizagem Única (Single Learning Activity, em inglês) é composta por uma unidade de método e assunto. Qualquer variação no método ou no tema caracteriza uma nova atividade de aprendizagem única. $\mathrm{O}$ assunto, ou campo, seria o que a pessoa efetivamente aprende. O método é a organização do formato usado para aprender ou ensinar; pode tomar a forma de programas educacionais, cursos, eventos e outras formas mais ou menos organizadas. No método, a mudança da mídia ou da ferramenta não resulta em uma configuração de um novo Single Learning Activity (SLA).

A Figura 3 é apresentada para explicar a relação entre o SLA, o curso e o programa.

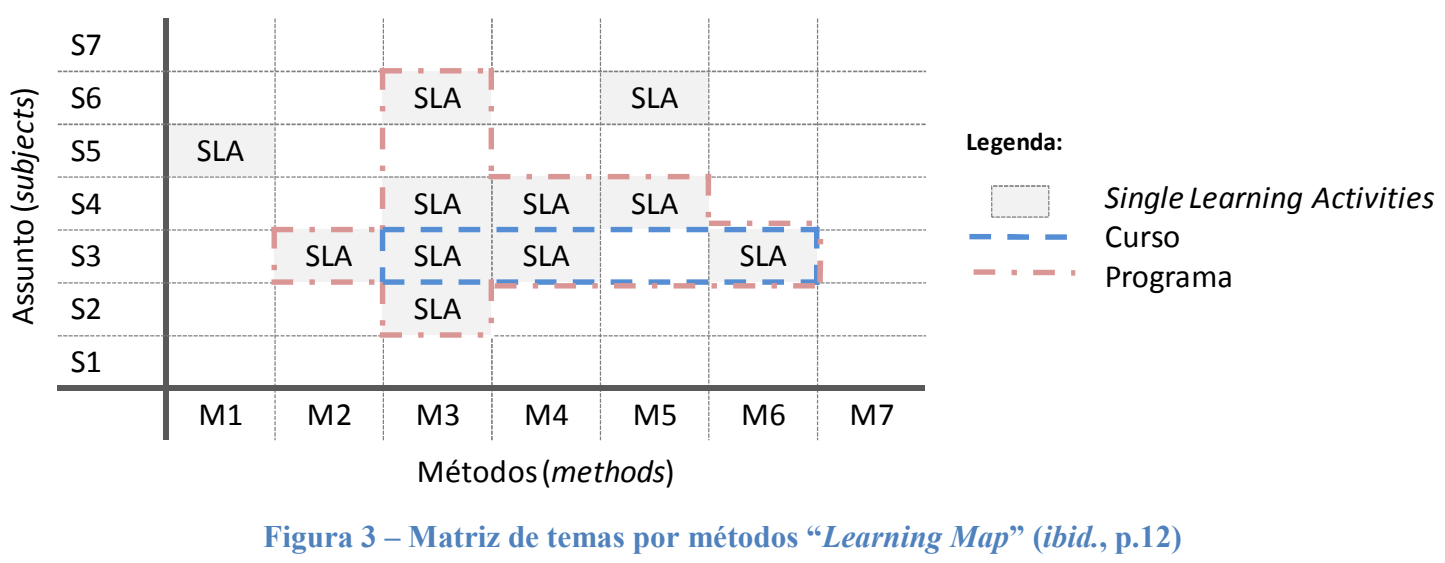

Cada intersecção entre um assunto e um método compõe um SLA. A composição de SLAs agrupados pela linha pontilhada de cor azul compõe um curso, cuja definição é "uma série 
planejada de atividades de aprendizagem única em uma área específica de um tema-assunto oferecido por um provedor" (EUROSTAT, 2006, 11). Programa, por sua vez, é composto por cursos e SLAs, podendo ser configurado por diferentes métodos e assuntos. A definição de programa é "um conjunto ou uma seqüência de atividades educacionais, na qual é organizado para atingir um objetivo pré-determinado ou um conjunto específico de tarefas educacionais" (EUROSTAT, 2006, 12). No “Learning Map" é representado pela linha pontilhada de cor vermelho.

No entanto, é claro que "uma atividade cujo propósito não é a aprendizagem pode também produzir aprendizagem" (ibid., p.9). E, estes conceitos e definições vistos nesta seção não consideram muito da aprendizagem obtida de maneira informal e casual, a qual é relevante para o objetivo deste trabalho.

Para Marsick e Watkins (2001, p.28) "a aprendizagem informal e casual ocorre em qualquer lugar em que as pessoas tenham necessidade, motivação e oportunidade de aprendizagem”. Logo, nem sempre são tão organizadas e nem sempre são intencionadas.

Quando se discute aprendizagem casual, a necessidade de colher (do inglês reap) as oportunidades de aprendizagem é sempre destacada, pois se pode experienciar algo bastante rico, sem na verdade aproveitar-se/apropriar-se de algo. Desta forma, por exemplo, um funcionário pode após um difícil processo de fusão não aprender nada com a experiência, ou mesmo até um funcionário participar de um treinamento e terminá-lo sem os conhecimentos apropriados.

Portanto, o aprendizado não é algo garantido. Sempre será algo potencial e uma das formas de alavancar a aprendizagem seria aumentar consciência das oportunidades de aprendizagem postas pelas experiências da vida (ibid.).

Diante desta discussão não seguimos as definições estabelecidas por Tough (1979), Heap (1996) e Eurostat (2006), pois a intencionalidade e a organização são características não garantidas para todos os eventos de aprendizagem. Além disso, somamos a característica da aprendizagem ser algo potencial. Preferimos então utilizar neste trabalho a definição de que evento de aprendizagem é uma oportunidade de aprendizagem que parte da necessidade, motivação ou consciência do indivíduo. 


\subsection{Adult Learning}

Embora há séculos seja conhecido que adultos aprendem como parte de suas vidas diárias, os estudos sistemáticos sobre o tema se iniciaram no início do século $\mathrm{XX}$. O primeiro livro publicado na área foi o "Adult Learning" de Thorndike et al (1928), no qual os autores abordaram o tema sob uma perspectiva psicológica comportamental, testando a capacidade de aprendizagem e de memória de adultos em condições de tempo controlado. Assim, como os outros primeiros estudos na área, a questão principal abordada era se os adultos poderiam aprender ou não.

Estes primeiros estudos também comprovaram que jovens aprendem melhor do que os mais velhos, hipótese que seria posteriormente desmistificada por Lorge (1947). Seus resultados apontaram que a idade em nada influenciava - inclusive pessoas acima de 70 anos apresentaram desempenho igual ao dos jovens -, os fatores mais relevantes eram a educação acumulada e habilidades.

Os testes de inteligência surgiram neste mesmo período. Geralmente, os estudantes pontuavam mais do que os adultos, entretanto quando os testes aumentavam de complexidade a situação se invertia (SCHAIE; WILLIS, 1986). Isso nos leva a crer que no envelhecer há uma perda em algumas áreas de inteligência e em outras há um ganho.

A partir da metade do século XX a discussão principal era se o Adult Learning poderia ser considerado um campo de estudo à parte da aprendizagem geral e da educação infantil em particular. Neste período surgiram os dois novos conceitos do Adult Learning: a Andragogia e o Self-Directed Learning.

A luz sobre o tema Adult Learning aumenta cada vez mais, visto que os fatores que proporcionam a sua demanda são tendências em franca evolução. Peterson e Associates (1979) levantaram as 10 razões para o crescimento do Adult Learning que se mantêm válidas nos dias atuais: 
1. Aumento da faixa etária da população;

2. Quanto mais educação as pessoas têm, mais elas querem;

3. A entrada das mulheres no mercado de trabalho;

4. Cobrança de qualidade dos consumidores estimula a busca de competência dos profissionais;

5. Mudanças tecnológicas;

6. Carreiras em transição;

7. A busca pela autorrealização;

8. Redução do analfabetismo;

9. Equidade social (reduz preconceitos raciais, sexuais, entre outros);

10. Benefícios indiretos da sociedade.

\subsubsection{Adult Learning e Andragogia}

Em 1968, Malcolm Knowles propôs "um novo rótulo, uma nova tecnologia” de Adult Learning para diferenciá-la da pedagogia no artigo publicado "Andragogy, not Pedagogy". Knowles adotou o termo europeu andragogia e o definiu como sendo "a arte e a ciência de ajudar os adultos a aprenderem", parafraseando a definição da pedagogia que seria "a arte e a ciência de ajudar as crianças a aprenderem" (KNOWLES, 1980, p. 43).

As cinco premissas (ibid.) que fornecem a base da andragogia descrevem o aprendiz adulto como alguém que:

1. Tem um autoconceito independente e que pode direcionar seu próprio aprendizado;

2. Tem acumulado uma grande quantidade de experiências de vida que é um recurso rico de aprendizagem;

3. Tem necessidades sociais relacionadas à mudança de papéis sociais;

4. É centrado em problemas e interessado na aplicação imediata do conhecimento;

5. É motivado a aprender por fatores internos e não externos.

Entretanto, a validade da andragogia como uma teoria de Adult Learning foi amplamente questionada nas décadas de 1970 e 1980 (por exemplo: DAVENPORT; DAVENPORT, 1985; HARTREE, 1984). Inclusive, Knowles (1989, p.112) chegou a concordar que a andragogia é 
menos uma teoria de Adult Learning do que "um modelo de suposições sobre aprendizagem ou uma estrutura conceitual que serve como uma base para uma teoria emergente".

O termo andragogia acabou adquirindo inúmeras novas interpretações e usos no decorrer do tempo. Dusan Savicevic, que introduziu o termo a Knowles, reconhece que há mais de 5 usos para o termo andragogia que inclusive resultaram em que na Europa o termo representasse o que nos EUA é conhecido como sendo educação de adultos (SAVICEVIC, 1991).

$\mathrm{Na}$ década de 1990 as críticas quanto à andragogia aumentaram (GRACE, 1996; PRATT, 1993). Grace (ibid.) repreende o fato de que nem todo adulto tem interesse de ser autodirigido na sua aprendizagem. Pratt (op. cit., p.21), por sua vez, argumenta que enquanto a "andragogia contribuiu para a compreensão dos adultos como aprendizes, ela fez pouco para expandir e clarificar nossa compreensão do processo de aprendizagem". Por finalizar esta discussão, outra citação de Pratt (ibid., p.21): “Andragogia tem sido adotada por legiões de educadores de adultos ao redor do mundo. [...] Muito provavelmente isso continue a ser a janela pela qual educadores de adultos tenham seu primeiro olhar para o mundo da educação de adultos".

\subsubsection{Características da Aprendizagem do Adulto}

Colocando de lado a discussão sobre a andragogia, passaremos a nos concentrar na aprendizagem do adulto. Antes de abordar as características do aprendiz adulto e o ambiente de aprendizagem, apresentaremos alguns motivadores que levam o adulto a aprender no âmbito profissional (EUROPEAN COMISSION, 2008):

- Aumento da probabilidade de encontrar e de se manter apto a um trabalho;

- Garantia de emprego (estabilidade);

- Aumento de renda;

- Aumento de produtividade;

- Desenvolvimento ocupacional, pessoal e de competências profissionais;

- Uma rota para qualificação de níveis mais elevados. 
Há na literatura revisada dezenas de autores que estudam a motivação para aprendizagem, mas percebe-se que estes limitam o escopo de aprendizagem às ações de educação e treinamento (SHEFFIELD, 1964; JOHNSTONE; RIVERA,1965; BURGESS, 1971; BOSHIER, 1971; 1977; 1982; GROTELUESCHEN, 1985; MORSTAINS; SMART, 1974; O’CONNELL,1999).

Em relação às características pessoais, existem diferenças de motivação ao aprendizado. Em relação à idade, "interesse em metas relacionadas ao emprego começam a declinar na faixa dos 50 anos e caem drasticamente na faixa dos 60 anos" (CROSS, 1981, p.92).

Jovens adultos também citaram as questões de trabalho como sendo mais relevantes, enquanto que adultos mais velhos citaram a curiosidade como sendo motivação primária à aprendizagem. (CROSS, 1981; CARP et al apud LEDERMAN, 1998).

Cross (op.cit.) também revelou que quanto mais as pessoas são educadas, mais elas se interessarão por aprendizado contínuo, mais elas descobrirão novas oportunidades e mais também irão participar.

Sobre as características do aprendiz adulto, Brookfield (1986) analisou diversos trabalhos (MILLER, 1964; KIDD; 1973, KNOX, 1977; BRUNDAGE; MACKERACHER, 1980; SMITH, 1982; DARKENWALD; MERRIAM, 1982) e resumiu as características gerais:

\footnotetext{
“Adultos mostram diversos estilos de aprendizagem - estratégias de codificação da informação, procedimentos cognitivos, organização mental - e aprendem de diferentes maneiras, em diferentes tempos e para propósitos diferentes. Como regra, entretanto, eles gostam que suas atividades de aprendizagem sejam centradas em problemas e que tenham significado para as suas situações de vida, e eles esperam que os resultados de aprendizagem tenham alguma aplicação imediata. As experiências passadas dos adultos afetam as suas aprendizagens atuais, às vezes servindo como alavancadoras, outras vezes como impeditivas. Aprendizagem eficaz está também ligado com a concordância do adulto com um auto-conceito de si mesmo como um aprendiz. Finalmente, adultos mostram uma tendência rumo ao auto-direcionamento em suas aprendizagens". (Brookfield, op. cit., p.31)
}

Também, para o adulto que busca aprendizagem é mais relevante saber fazer do que apenas saber, em outras palavras, "em novas tarefas que os adultos tentam dominar o que conta não é a informação, mas sim a competência e o desempenho" (KNOX, 1977, p.408). 
Cross (1986) elaborou as Características dos Adultos como Aprendizes, um modelo que considera as características pessoais (exemplo: fatores físicos, psicológicos e socioculturais) e as características situacionais (exemplo: dedicação parcial ou integral aos estudos e aprendizado voluntário ou obrigatório).

Darkenwald e Merriam (1982) sintetizaram as teorias de aprendizagem de diversas correntes teóricas e chegaram a oito princípios da aprendizagem:

1. A pré-disposição do adulto em aprender depende da quantidade de aprendizagem prévia;

2. Motivação intrínseca produz aprendizagem mais persuasiva e permanente;

3. Reforços positivos (recompensas) de aprendizagem são mais eficazes do que reforços negativos (punições);

4. Para maximizar a aprendizagem, a informação deve ser apresentada em uma organização mais atraente ${ }^{9}$;

5. Aprendizagem, sobretudo a que se refere ao desenvolvimento de habilidades, é melhorada pela repetição, preferencialmente a sistematicamente espaçada por períodos de tempo;

6. Materiais e tarefas significativos são mais facilmente aprendidos e lembrados por mais tempo do que aqueles não significativos e sem lógica;

7. Participação ativa nas atividades de aprendizagem melhora a aprendizagem mais do que a participação passiva;

8. Fatores ambientais afetam a aprendizagem.

Além da importância das características do indivíduo adulto, é importante também compreender o ambiente como parte deste processo. Ambientes de aprendizado eficazes são ambientes baseados na maneira em que as pessoas aprendem. (DESFROGES, 2001 apud WORLD BANK, 2003; BRANSFORD et al 2000 apud WORLD BANK, 2003). Os ambientes de aprendizado eficazes se diferem dos esquemas de aprendizados tradicionais por que são:

- Centrados no aprendiz: reconhece que o aprendiz adquire novos conhecimentos e habilidades melhor quando o conhecimento e as habilidades estão conectados com o que ele já sabe;

\footnotetext{
${ }^{9}$ Ou "na moda", seguindo a tradução literal do termo em inglês "fashion" utilizado.
} 
- Ricos de conhecimento: o aprendiz deve ser capaz de resgatar, aplicar e transferir conhecimento de uma área para novas situações e contextos;

- Dirigidos por avaliação: há mensuração do progresso a partir do ponto de início em direção do ponto pretendido, por meio de metas claras e bem definidas.

- Conectados em grupos ${ }^{10}$ : além de aumentar a motivação dos aprendizes, possibilita a aprendizagem implícita e transmissão de conhecimento entre os indivíduos.

\subsubsection{Lifelong Learning (LLL)}

“Lifelong Learning não é um privilégio ou um direito; é simplesmente uma necessidade de qualquer um, jovem ou adulto, que deve viver num ritmo escalar de mudança - na família, no trabalho, na comunidade, e na sociedade global." (Cross, 1986, p.ix)

Nos anos recentes, o termo "aprendizagem" tem sido usado em muitos países por policymakers, praticantes e alguns pesquisadores da educação em preferência aos termos "educação" ou "treinamento" (FULLER et al, 2003). Esta mudança é mais bem representada pela adoção do termo "Lifelong Learning”.

Um sistema de Lifelong Learning abrange o aprendizado por todo o ciclo de vida, desde "o início da infância até a aposentadoria ${ }^{11 "}$ (KNOWLES, 1975). Reconhece que as pessoas aprendem de várias maneiras diferentes, assim abrange toda a educação formal (exemplo: escola, instituições de treinamento, universidades), educação não-formal (exemplo: treinamentos estruturados on-the-job) e o aprendizado informal (exemplo: habilidades desenvolvidas pela socialização).

Lifelong Learning pode ser definido como sendo "todas as atividades de aprendizagem empreendidas durante a vida inteira com o objetivo de melhorar o conhecimento, habilidades e competências dentro de uma perspectiva pessoal, cívica, social e/ou de emprego" (EUROPEAN COMISSION, 2001)

\footnotetext{
${ }^{10}$ No texto original em inglês utiliza-se o termo "community" que, além de comunidade, significa "grupo de pessoas".

11 “A expressão já havia sido usada anteriormente apenas para aprendizagem por Gallup (1955); “O processo de aprendizagem começa no nascimento e termina na morte; entre outras derivações, é frequente encontrar o termo "Do berço à cova" (do inglês: "cradle to grave")
} 
As diferenças entre a aprendizagem tradicional e a visão proposta pelo Lifelong Learning é apresentada abaixo no Quadro 4 - Características do modelo tradicional e LLL (WORLD BANK, 2003, p.29).

\begin{tabular}{|l|l|}
\hline Aprendizagem tradicional & Lifelong Learning \\
\hline O professor é a fonte de conhecimento & Educadores são guias para fontes de conhecimento \\
\hline Aprendizes recebem conhecimento do professor & Pessoas aprendem fazendo \\
\hline Aprendizes trabalham por si mesmos & Pessoas aprendem em grupos e um com outro \\
\hline $\begin{array}{l}\text { Testes são dados para prevenir o progresso até que os } \\
\text { estudantes tenham completamente dominado um conjunto de } \\
\text { habilidades e para racionar o acesso para aprendizados futuros }\end{array}$ & $\begin{array}{l}\text { Avaliação é usada para guiar estratégias de aprendizagem e } \\
\text { identificar trajetos de aprendizagem futura }\end{array}$ \\
\hline $\begin{array}{l}\text { Todos os aprendizes fazem as mesmas coisas } \\
\text { Professores recebem treinamento inicial mais treinamento no } \\
\text { serviço ad hoc }\end{array}$ & $\begin{array}{l}\text { Educadores desenvolvem planos individuais de aprendizagem } \\
\text { "Bons" aprendizes são identificados e recebem permissão para lifelong learners. Treinamento inicial e }\end{array}$ \\
\hline $\begin{array}{l}\text { continuar a educação } \\
\text { cessofissional contínuo são conectados }\end{array}$ & $\begin{array}{l}\text { Pessoas tem acesso às oportunidades de aprendizagem por } \\
\text { todo o tempo de vida }\end{array}$ \\
\hline
\end{tabular}

Quadro 4 - Características do modelo tradicional e LLL (WORLD BANK, 2003, p.29)

LLL compreende todas as atividades de aprendizagem que:

- São intencionadas: são atividades empreendidas com o propósito de melhorar o comportamento, informação, conhecimento, compreensão, atitudes, valores e habilidades;

- São empreendidas em uma base em andamento: não são eventuais ou aleatórias, mas têm elementos de duração e continuidade;

- Independe se são formais ou não: inclui diferentes tipos de aprendizagem como escolas de segunda chance, educação no trabalho ou não, autoaprendizagem, entre outros;

- Independente de fontes de financiamento: é financiado tanto pelo setor público ou privado, quanto pelo próprio indivíduo;

- Independe dos modos de provisão: uso de meios tradicionais ou modernos, como tecnologias de informação e comunicação (EUROSTAT, 2006).

Abrange ainda toda a população independente da idade e do Status no mercado de trabalho. Inclui todos os tipos de atividades desde a educação da infância até educação de lazer para pessoas aposentadas.

Inúmeros estudos estão sendo promovidos sobre este tema por organismos internacionais com diferentes objetivos, alguns monitoram o panorama da mão-de-obra dos países (EUROPEAN 
COMISSION, 2001; 2008; OECD, 1996; 2002; 2008a; 2008b; UNESCO, 2007; WORLD

BANK, 1995; 2002; 2003), outros focam no desenvolvimento regional, por exemplo da China (DAHLMAN et al, 2007).

O tema lifelong learning foi mencionado como "um caminho que asseguraria uma transição bem sucedida [da Europa] em direção a sociedade do conhecimento" (EUROSTAT, 2006, p.5).

\subsection{Estruturas de Classificação de Eventos de Aprendizagem}

Classificações e nomenclaturas são itens básicos para organizar elementos em categorias bem definidas. Estas classificações são pré-requisitos para a coleta de dados e desempenham um importante papel na qualidade dos resultados, além de possibilitar comparação de estudos distintos em diferentes países.

Apresentaremos algumas estruturas encontradas na literatura e, na seqüência, avaliaremos suas contribuições e limitações. Por fim, uma nova estrutura é proposta para utilização neste trabalho.

\subsubsection{Manual de Classificação das Atividades de Aprendizagem}

Para a educação, temos estruturas bem definidas para classificar os estágios de desenvolvimento do indivíduo. O mais difundido é o International Standard Classification of Education (ISCED, 1997), criado pela Unesco Institute of Statistics no começo da década de 1970 para se tornar uma ferramenta apropriada para reunir, compilar e apresentar estatísticas da educação nos países. Outra estrutura de educação comumente adotada é o National Framework of Qualifications (NFQ). Originalmente desenvolvido pela Irlanda em 2003, a estrutura apresenta 10 níveis que vai desde a formação básica até o doutorado.

Uma visão mais ampla é fornecida pelo Classification Learning Activities - Manual (CLA), elaborado em 2002 pelo Statistical Office of the European Communities, mais conhecida como Eurostat. A concepção do CLA foi elaborada no conceito do Lifelong Learning, por isso 
é muito mais abrangente que as demais estruturas de classificação que só compreendem a educação. O CLA cobre todos os tipos de oportunidades de aprendizagem e trajetórias de educação e aprendizagem.

A definição de LLL adotada é a definida no relatório "Making a European Area of Lifelong Learning a Reality" (EUROPEAN COMISSION, 2001), assim LLL são "todas as atividades de aprendizagem ${ }^{12}$ empreendidas durante a vida inteira com o objetivo de melhorar o conhecimento, habilidades e competências dentro de uma perspectiva pessoal, cívica, social e/ou de emprego".

Educação e treinamento podem ser classificados em quatro grandes grupos: educação formal; educação não-formal; aprendizagem informal; e, aprendizagem aleatória/acidental. Como a classificação do CLA considera apenas atividades de aprendizagem aquelas que têm intencionalidade, desconsideraremos esta última. Assim, abaixo segue uma descrição de cada um dos 3 grupos:

- Educação Formal: é a educação proporcionada pelas escolas, colégios, universidades ou quaisquer outras entidades de ensino.

- Educação não-Formal: qualquer atividade educacional organizada e suportada que não corresponde necessariamente ao sistema de "escada" contínua da educação formal. São exemplos: educação básica infantil fora da escola, programas de alfabetização adulta, habilidades da vida e cultura em geral.

- Aprendizagem Informal: é a atividade de aprendizagem intencional menos estruturada e organizada. Pode incluir eventos de aprendizagem direcionados pela família, ambiente de trabalho e dia a dia da pessoa.

A diferença básica entre a educação formal e a não-formal é que a primeira proporciona uma qualificação (ou diploma/título) dentro da estrutura nacional de educação (ex: National Framework of Qualification - NFQ). No caso do Brasil, o Ministério da Educação é o órgão responsável por determinar as regras de ensino formal desde a educação básica até o nível superior.

\footnotetext{
${ }^{12}$ A atividade de aprendizagem já foi discutida em capítulos anteriores.
} 
A Figura 4, apresentada abaixo, ilustra melhor a classificação das atividades de aprendizagem nos diferentes grupos.

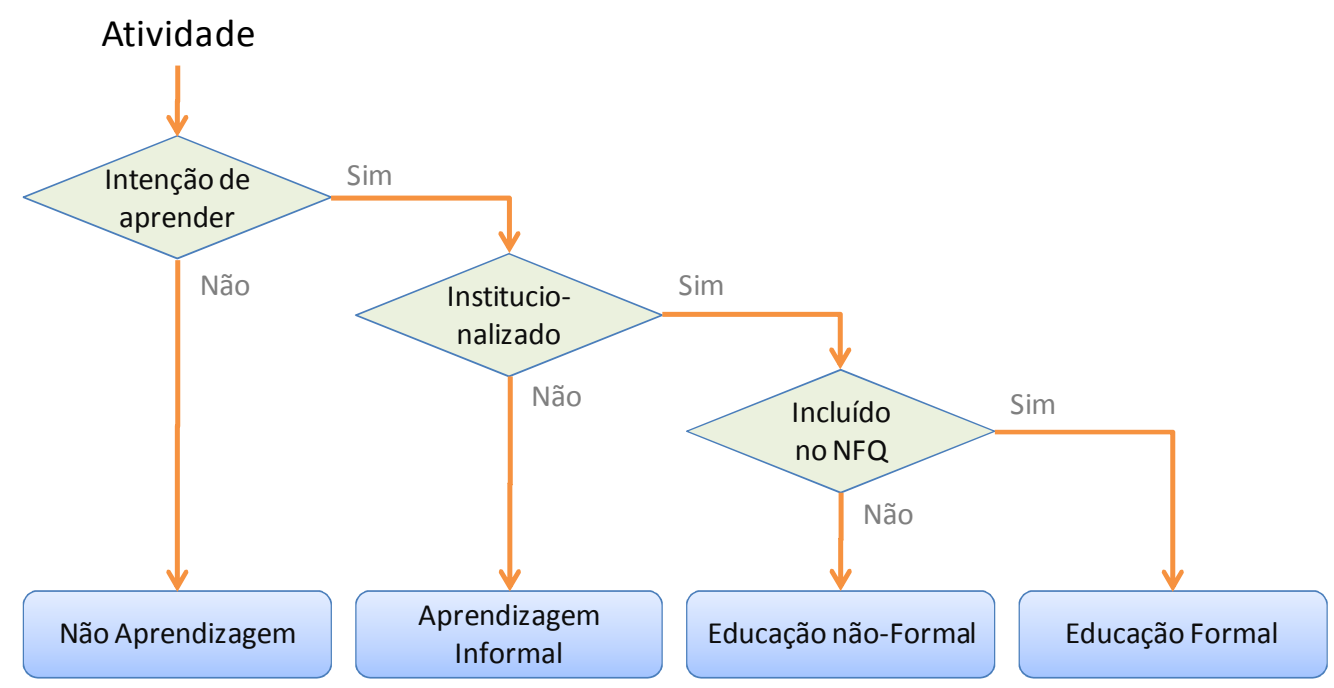

Figura 4 - Alocação das atividades de aprendizagem segundo as 3 categorias amplas (EUROSTAT, 2006, p.19)

O CLA apresenta um resumo das classes e subclasses, bem como, a distribuição entre as categorias da estrutura de classificação. Abaixo segue a extração do resumo (EUROSTAT, 2006):

Códigos Categorias / Classes / SubClasses

1. Educação formal

2. Educação não formal

a. Programas não-formais: conjunto ou seqüência de atividades educacionais organizado para atingir um objetivo pré-determinado ou um grupo específico de tarefas educacionais.

b. Cursos

i. Cursos conduzidos via ensino em sala de aula (inclui palestras): Aprendizado conduzido por um professor/tutor/instrutor que transmite conhecimento para um grupo de pessoas em uma sala de aula.

ii. Cursos com combinação teórico-prático (inclui workshops): Cobre todos os cursos que combinam instrução teórica com a prática real ou situação simulada. Ex.: cursos “hands-on" (mão na massa).

iii. Cursos conduzidos por meio de educação à distância e aberta: cursos assíncronos mediados ou não pela tecnologia. 
iv. Aulas particulares: série planejada de aprendizagem oferecida por um especialista selecionado para aprofundar conhecimento ou habilidades e proporcionar um aprendizado mais intenso.

v. Treinamentos guiados on-the-job: Períodos de treinamento, instrução ou experiência prática planejados e guiados, usando ferramentas normais do trabalho, bem como o ambiente ou a situação de trabalho. Principalmente voltados para novos empregados.

vi. Demais não citados

3. Aprendizagem informal

c. Aprendizagem ensinada

i. Coaching / ensino informal: Ampla variedade de experiências de aprendizado organizado e não-institucionalizado oferecido por um especialista, também visa aprofundar conhecimento ou habilidades e proporcionar um aprendizado mais intenso e personalizado.

ii. Visitas guiadas: Ampla variedade de eventos designados para transmitir informação dentro de um período de tempo limitado num dado local, que é o principal meio para apresentar o tema.

d. Aprendizagem não ensinada

i. Autoaprendizagem: é o aprendizado sozinho conduzido pelo próprio indivíduo.

ii. Aprendizagem em grupo: é o aprendizado que ocorre em diversos tipos de grupos informais e que não tem a presença de um tutor.

iii. Prática (exercício): Envolve a implementação ou repetição de um conhecimento, métodos ou instruções relacionado algum tema já recebido, com o objetivo de aumentar o desempenho no assunto em específico.

iv. Visitas não guiadas: Inclui qualquer visita com o objetivo de aprender sem que exista a presença de um guia.

\subsubsection{Taxonomia de Aprendizagem Informal}

Dois pesquisadores ingleses, Graham Cheetham e Geoff Chivers, desenvolveram um artigo para o Journal of European Industrial Training, em 2001. A primeira parte apresentava uma 
revisão de inúmeras teorias, conceitos e abordagens sobre aprendizagem que são relevantes para o desenvolvimento profissional. A segunda constitui ao final uma tentativa de formar uma taxonomia de métodos de aprendizagem profissional informais.

A metodologia da parte prática foi baseada em uma primeira fase com 80 entrevistas com pessoas de 20 profissões distintas. A segunda fase, envolveu 372 respondentes das 6 profissões mais representativas em uma pesquisa quantitativa para avaliar a importância dos 10 tipos de aprendizagem informal encontrados na revisão teórica. A figura abaixo apresenta o resultado da segunda fase:

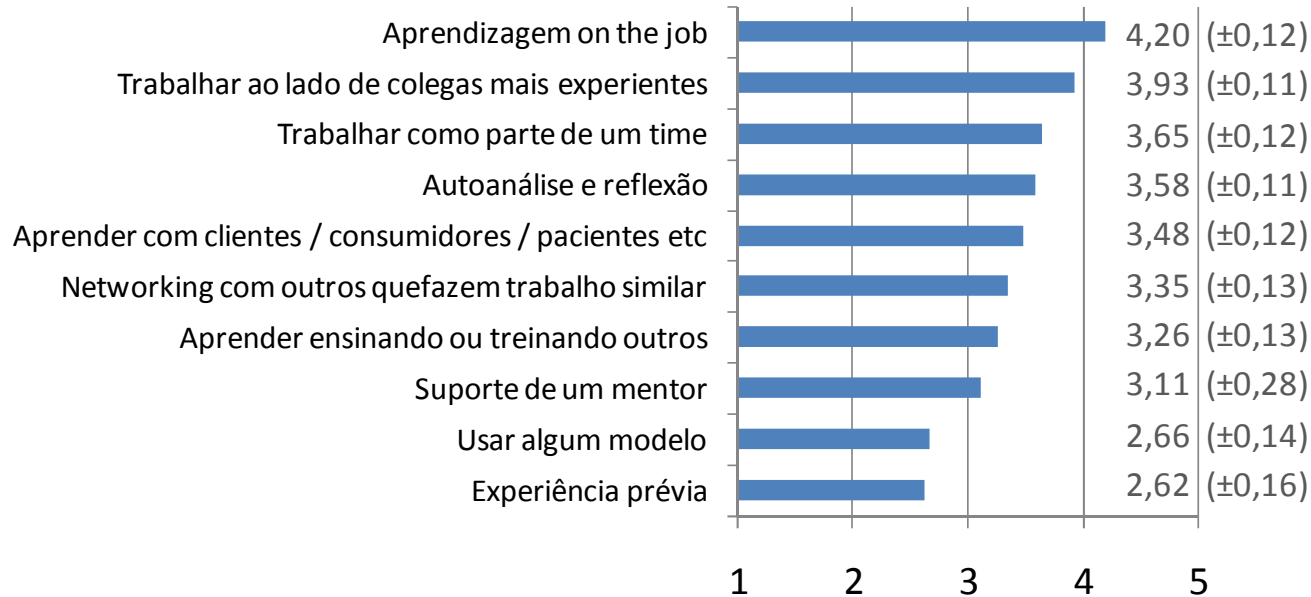

Figura 5 - Contribuição de várias formas de aprendizagem informal para a competência. Fonte: ibid., p.271.

Após medir a importância de cada item - os quais não são analisados, pois o objetivo desta etapa do trabalho é analisar as estruturas de aprendizagem -, os pesquisadores analisaram inúmeros comentários e casos de experiências relatados pelos entrevistados e respondentes em questões qualitativas e abertas, e descreveram as seguintes formas e aprendizagem informal.

- Prática e repetição: É o ditado "A repetição faz a perfeição". Após executar uma tarefa novamente é possível fazê-la mais rápida e melhor. $\mathrm{O}$ ensaio também pode ser considerado como uma repetição prévia.

- Aprendizagem excessiva: é a exposição frequente a altos níveis de algo em que as pessoas possuem dificuldade para que as pessoas superem suas barreiras. Exemplo: um psicoterapeuta apresentava dificuldade em controlar as suas emoções ao lidar com 
pacientes severamente abalados ou que foram seqüestrados, após um período trabalhando em um hospício com pacientes em estado terminal de doença, para ele "ninguém mais parecia ser doente" (CHEETHAM; CHIVERS, 2001, p.272).

- Observação: ocorre quando acompanhamos alguém com a intenção de aprender, observando como esta executa as suas atividades. Também pode contribuir para o desenvolvimento de habilidades pessoais ao observar o comportamento dos demais colegas de trabalho.

- Modelo (Role Model): as pessoas enxergam outras, ou as ações delas, como algo a ser seguido ou evitado. Este conceito foi desenvolvido por Bandura (1986). Os autores dividiram este ponto em três estágios: 1) Sintetizar (pequenas coisas são absorvidas por osmose mais ou menos inconscientemente); 2) Emular (esforço consciente em agir como alguém em certas condições); 3) Atualizar (o praticante sente em ser na verdade o modelo).

- Mentoring: ocorre quando um mentor formal ou informal fornece dicas e conselhos em relação à vida, ou mesmo à ocupação e à carreira, para alguém mais jovem e menos inexperiente.

- Aprender a partir de problemas complexos ou multi-facetados: desafios maiores exigem mais das pessoas e proporcionam aprendizado profundo.

- Experiências inovadoras e pioneiras: projetos e ações empreendedoras proporcionam mais aprendizado do que as rotineiras.

- Trabalhar acima do nível: desempenhar atividades mais complexas que o seu espaço ocupacional atual, faz com que você desenvolva competências de níveis maiores como, por exemplo, a perspectiva estratégica e a visão holística.

- Trabalhar ao lado de colegas mais experientes: a osmose ocorre principalmente com conhecimentos tácitos e know how.

- Networking: é a colaboração e a troca de experiências em grupos formais e informais de profissionais.

- Trabalhar em times: participar de projetos com pessoas que pensem e abordem os problemas de outra maneira, ou que possuem e habilidades.

- Trabalho multidisciplinar: parecido com o anterior, entretanto com profissionais de outras formações.

- Mudança de perspectiva: é quando ocupamos outra posição e enxergamos outro ponto de vista. Ocorre quando, por exemplo, um gerente de marketing passa também a ser um cliente dos serviços da empresa, ou um trainee participa de um job rotation na empresa. 
- Aprender com clientes / pacientes / consumidores: é o feedback imediato do seu desempenho e também uma fonte de identificar pontos de melhoria.

- Aprender com paraprofissionais: ocorre quando um jovem profissional como, por exemplo, um médico, aprende com um profissional de outra disciplina relacionada, geralmente de menor Status, porém com mais experiência, como correspondente do exemplo teríamos um instrumentador cirúrgico.

- Feedback: é o ato de solicitar opinião sobre seu desempenho e avaliação de entregas para um chefe, colega de trabalho, cliente etc. Pode ser formal e estruturado ou ocorrer esporadicamente no dia a dia do trabalho.

- Aprender a partir de críticas: ser aberto à e crescer por meio da crítica construtiva, ao invés de refutar e negar toda crítica externa ou de se abalar emocionalmente.

- Autoconhecimento e autoimagem: reconhecer pontos fortes e fracos, e ser realista quanto aos próprios objetivos.

- Simulação: é agir dentro de um ambiente controlado e fictício. Um administrador pode participar em grupo de jogos de empresas (simuladores eletrônicos), ou um dentista pode operar um dente dentro da boca de um boneco.

- Aprender por articulação: é quando se aprende ao estruturar logicamente um pensamento e justificá-lo oralmente ou por escrito de maneira inteligível. Esta forma de aprendizagem é corroborada pelos estudos de Piaget (1986) e Vygotsky (1962), já que aprendizagem, linguagem e pensamento são intimamente conectados.

- Aprender ensinando os outros: é uma forma particular da anterior, pois ensinar exige previamente a estruturação do pensamento.

- Transferência cultural: trabalhar em outra cultura, principalmente no exterior, cria o ambiente para a pessoa aprender dado a necessidade de se adaptar à nova cultura. Como conseqüência, temos, entre outras, a internalização de boas práticas da nova cultura e o aumento da autoconfiança, visto o desafio de enfrentar as dificuldades sozinho.

- Aprendizagem e transferência extraocupacional: é o aprendizado ganho fora do trabalho em hobbies praticados ou experiências de vida que tem aplicação no trabalho. Ex.: melhorar oratória por meio do teatro; desenvolver e manter destreza manual e sensibilidade tátil pela prática de piano ou violão.

- Aprender por conexão: é quando deliberadamente fazemos conexão entre novas aprendizagens e gama de conceitos já firmemente encravados em nossa mente, ou quando deliberadamente conectamos diferentes elementos com novas informações. 
- Mudança de mindset ou experiências "Damascus Road": o desenvolvimento da competência profissional é um processo gradual e interativo, cujas ondas são disparadas por certas experiências formadoras. Entretanto, alguns fatos pontuais ou eventos são capazes de transformar o todo de uma única vez, atuando como divisores d'água da experiência. As conseqüências são, por exemplo, mudança da filosofia profissional - dado a nova maneira de ver o mundo -, melhoria do auto-conhecimento, impulsionar confiança interna ou motivação profissional.

- Modelos mentais, imaginação e outros esquemas psicológicos: são os processos mentais para compreender conceitos complexos ou se preparar para tarefas desafiadoras. Ex.: Lateral Thinking (De BONO, 1967), Mind Mapping (BUZAN, 1988), Neuro-Linguistic Programming (BANDLER \& GRINDER, 1979), autocomunicação (VYGOTSKY, 1962), truques mentais ou imaginação, otimismo, quebrar ideias complexas em estágios menores entre outros.

- Reflexão: exerce papel em diversas outras formas de aprendizagem (SCHÖN, 1983, 1987), todavia pode ser exercida isoladamente ou em grupo; pode ser desestruturada ou sistematizada por técnicas, como debriefing (PEARSON \& SMITH, 1985) e reflective writing (WALKER, 1985).

- Enfrentar stress profissional: são técnicas utilizadas para enfrentar a pressão e as situações difíceis do trabalho para manter o desempenho do profissional elevado. O aprendizado é a própria técnica.

Com o surgimento de novas formas, a proposta inicial foi alterada e estruturada segundo a Taxonomia de Bloom de Objetivos Educacionais (BLOOM, 1956). Assim doze tipos de processos de aprendizagem ou mecanismos de aprendizagem emergiram, os quais são compostos por experiências de aprendizagem ou eventos de aprendizagem. Os doze tipos são descritos abaixo e na seqüência o quadro completo com o segundo nível da taxonomia proposta.

- Prática e repetição;

- Reflexão;

- Observação e cópia;

- Feedback;

- Transferência extraocupacional;

- Forçar atividades; 
- Mudança de perspectiva;

- Interação Mentor / Coach;

- Absorção inconsciente ou osmose;

- Mecanismos psicológicos / neurológicos;

- Articulação;

- Colaboração e ligação.

\begin{tabular}{|c|c|}
\hline $\begin{array}{l}\text { Mecanismo de } \\
\text { aprendizagem geral }\end{array}$ & Experiência típica de aprendizagem ou evento \\
\hline \multirow[t]{5}{*}{ Prática e repetição } & $\begin{array}{l}\text { Interação / reinteração (fazer algo muitas vezes e gradualmente aprimorando- } \\
\text { a) }\end{array}$ \\
\hline & Simulação \\
\hline & Treino e prática \\
\hline & Ensaio (mental ou físico antes de uma atividade ou evento) \\
\hline & Aprendizagem / treinamento em excesso \\
\hline \multirow[t]{11}{*}{ Reflexão } & Autoanálise / Autoavaliação \\
\hline & Refletir sobre uma ação (após uma atividade ou evento) \\
\hline & Refletir na ação (no meio de uma atividade) \\
\hline & Refletir antes da ação (antes de fazer algo) \\
\hline & Reflexão em grupo / coletiva \\
\hline & Auditoria prática (ex.: auditoria médica) \\
\hline & Escrever um diário reflexivo \\
\hline & Reflexão de como os demais fazem as coisas \\
\hline & Reprocessamento mental (de um evento ou experiência) \\
\hline & Debriefing \\
\hline & Aprender com as falhas (analisando o que aconteceu de errado e o por quê) \\
\hline \multirow[t]{7}{*}{ Observação e cópia } & Observação estrutura e crítica dos outros \\
\hline & Observação informal / casual dos outros \\
\hline & Usar um modelo positivo (tentar fazer algo como alguém) \\
\hline & Usar um modelo negativo (esforçar-se para não fazer algo como alguém) \\
\hline & Shadowing \\
\hline & Sintetizar / emular / atualizar (níveis de modelagem) \\
\hline & Modificação de abordagem observada (desenvolver estilo próprio) \\
\hline \multirow[t]{9}{*}{ Feedback } & Avaliação / revisão de desempenho \\
\hline & Aprender a partir de críticas / reclamação \\
\hline & Feedback / avaliação 360 graus \\
\hline & Revisão de colegas \\
\hline & Avaliação de colegas \\
\hline & Exercícios de avaliação \\
\hline & Ouvir efetivamente (ao que os outros dizem sobre a sua performance) \\
\hline & Aprender com clientes / pacientes / paraprofissionais \\
\hline & Ler linguagem corporal (como as pessoas reagem a você?) \\
\hline
\end{tabular}




\begin{tabular}{|c|c|}
\hline $\begin{array}{l}\text { Mecanismo de } \\
\text { aprendizagem geral }\end{array}$ & Experiência típica de aprendizagem ou evento \\
\hline \multirow{5}{*}{$\begin{array}{l}\text { Transferência extra } \\
\text { ocupacional }\end{array}$} & Experiências prévias \\
\hline & Aprender transferida da educação formal (transformar teoria em prática) \\
\hline & Experiência transferida de outras ocupações anteriores \\
\hline & Experiências provadas (antes de entrar na profissão) \\
\hline & $\begin{array}{l}\text { Aprender fora do trabalho (ex. lazer, atividades de hobby, trabalho } \\
\text { voluntário) }\end{array}$ \\
\hline \multirow[t]{9}{*}{ Forçar atividades } & Trabalhar acima do nível \\
\hline & Experiências profundas \\
\hline & Exigência por tarefas complexas ou problemas \\
\hline & $\begin{array}{l}\text { Experiências holísticas (requer múltiplas habilidades e uma compreensão } \\
\text { global) }\end{array}$ \\
\hline & Experiências multifacetadas \\
\hline & Inovação (desenvolver novas ideias ou abordagens) \\
\hline & Experiências traumáticas \\
\hline & Experiências desafiadoras \\
\hline & Atividades pioneiras \\
\hline \multirow{7}{*}{$\begin{array}{l}\text { Mudança de } \\
\text { perspectiva }\end{array}$} & Transferência de papel \\
\hline & Mudança de trabalho \\
\hline & Trabalhar com profissões cruzadas \\
\hline & Trabalhar multiculturalmente \\
\hline & Mudança de perspectiva mental \\
\hline & Insight ou Inspiração inesperada \\
\hline & Experiências "Damascus Road" \\
\hline \multirow{7}{*}{$\begin{array}{l}\text { Interação Mentor / } \\
\text { Coach }\end{array}$} & Coaching \\
\hline & Dicas / aconselhamento \\
\hline & Tutoria \\
\hline & Conselho para a ocupação / carreira / vida \\
\hline & Atividades de ressonância (testar ideias com alguém) \\
\hline & Instrução / demonstração \\
\hline & Interrogação (questionar uma pessoa mais experiente) \\
\hline \multirow{6}{*}{$\begin{array}{l}\text { Absorção inconsciente } \\
\text { ou osmose }\end{array}$} & Trabalhar ao lado de colegas mais experientes \\
\hline & Networking (profissionais amigos) \\
\hline & Trabalhar ao lado de colegas experientes \\
\hline & Trabalhar ao lado de um modelo \\
\hline & Andar na companhia de experts \\
\hline & $\begin{array}{l}\text { Atividades de aprendizagem (ex.: trabalhar proximamente ao chefe ou ao } \\
\text { aluno master) }\end{array}$ \\
\hline
\end{tabular}




\begin{tabular}{|c|c|}
\hline $\begin{array}{l}\text { Mecanismo de } \\
\text { aprendizagem geral }\end{array}$ & Experiência típica de aprendizagem ou evento \\
\hline \multirow{15}{*}{$\begin{array}{l}\text { Mecanismos } \\
\text { psicológicos / } \\
\text { neurológicos }\end{array}$} & Usar modelos mentais / cognitivos (ajudar a compreender algo) \\
\hline & Representação gráfica (uso de modelos / mapas / gráficos etc.) \\
\hline & Fazer hipóteses / conceitualizações / teorizações \\
\hline & Pensamento positivo \\
\hline & $\begin{array}{l}\text { Otimismo deliberado / forçado (olhar para o lado positivo / esperar os } \\
\text { melhores resultados) }\end{array}$ \\
\hline & Visualização \\
\hline & Autocomunicação \\
\hline & Técnicas de Programação NeuroLinguística \\
\hline & Preparação mental (entrar diretamente na estrutura mental) \\
\hline & Aprender por conexão / associação (ex.: ideias com outras ideias ou coisas) \\
\hline & Técnicas de pensamento lateral \\
\hline & Mudança de modelo mental \\
\hline & $\begin{array}{l}\text { Escolha de abordagens de aprendizagem apropriadas (para o que você está } \\
\text { tentando aprender) }\end{array}$ \\
\hline & $\begin{array}{lllll}\begin{array}{l}\text { Aprendizagem de técnicas "Todo o cérebro" } \\
\text { criativas/artísticas, quanto as lógicas do cérebro) }\end{array} & \text { (explorar tanto partes } \\
\end{array}$ \\
\hline & Simplificação (de ideias complexas em partes componentes) \\
\hline \multirow[t]{7}{*}{ Articulação } & Ensinar / tutorar / instruir / mentorar outras \\
\hline & Escrever artigos / artigos acadêmicos / relatórios etc. \\
\hline & Apresentar palestras \\
\hline & Expor em conferências \\
\hline & Justificar / defender / explicar ações \\
\hline & $\begin{array}{l}\text { Dar comentários simultâneos nas ações (ex.: enquanto você está fazendo algo } \\
\text { / aprende alguma coisa) }\end{array}$ \\
\hline & $\begin{array}{l}\text { Desenvolver materiais de aprendizagem (inclui materiais de aprendizagem } \\
\text { aberto e à distância) }\end{array}$ \\
\hline \multirow[t]{9}{*}{ Colaboração e ligação } & Trabalho em time \\
\hline & Projetos colaborativos \\
\hline & Aprender com para profissionais (ex.: doutores aprendendo com enfermeiras) \\
\hline & Aprendendo com clientes / pacientes \\
\hline & Colaborando com clientes / pacientes (ex.: na solução dos problemas deles) \\
\hline & Colaborando com pessoas de outras disciplinas \\
\hline & Trabalhando em times multidisciplinar \\
\hline & Colaboração internacional \\
\hline & Exercícios de formação de times \\
\hline
\end{tabular}

\subsubsection{Matriz de Marcia L. Conner}

A consultora americana Marcia L. Conner elaborou em 2004 uma matriz para classificar as oportunidades de aprendizagem em que há quatro categorias apresentadas - aprendizagem formal, informal, intencional e inesperada -, e mais uma quinta categoria implícita aprendizagem não-formal. 
Embora já desenvolvidos conceitualmente, a autora preferiu atribuir sua própria definição para as cinco categorias (CONNER, 2006, p.2):

- Aprendizagem formal: inclui o sistema escolar hierarquicamente estruturado que vai da escola primária até a universidade e programas criados em negócios para treinamento técnico e profissional;

- Aprendizagem informal: descreve o processo ao longo da vida onde indivíduos adquirem atitudes, valores, habilidades e conhecimento pela experiência diária e as influências e recursos educativos em seu ambiente, da família e de amigos, de trabalhar e se divertir, do mercado, da biblioteca e da mídia em massa;

- Aprendizagem intencional: é o processo pelo qual um indivíduo objetiva aprender algo e se empreende a alcançar este objetivo;

- Aprendizagem casual: acontece quando nas atividades diárias um indivíduo aprende algo que não havia intencionado ou esperado;

- Aprendizagem não-formal: é qualquer atividade educativa fora do sistema formal estabelecido, seja operando separadamente ou como uma importante característica de alguma atividade mais ampla pretendida a servir objetivos de aprendizagem identificados.

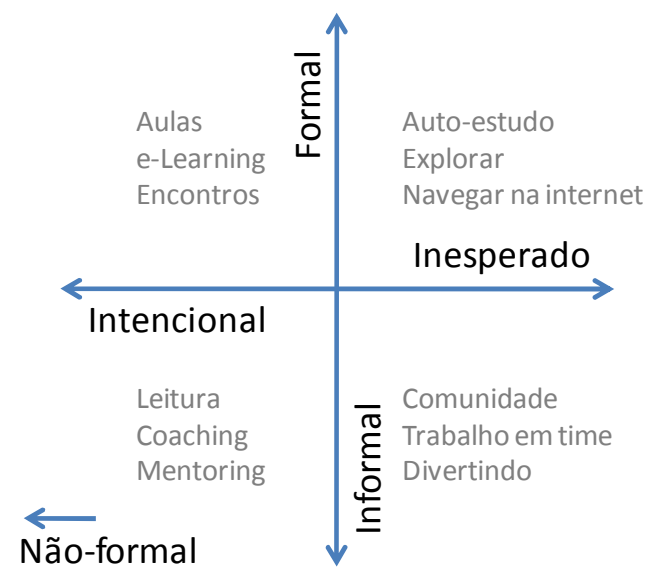

Figura 6 - Adaptado de cinco categorias de Marcia L. Conner (ibid., p.1-2)

\subsection{Análise e Proposta de uma Nova Estrutura}


Após a revisão das estruturas de classificação, apresentamos o quadro resumo da análise abaixo.

\begin{tabular}{|c|c|c|c|}
\hline Estrutura & Descrição & Pontos positivos & Pontos negativos \\
\hline \multirow[t]{2}{*}{$\begin{array}{l}\text { EUROSTAT, } \\
2006\end{array}$} & \multirow{2}{*}{$\begin{array}{l}\text { Estrutura desenvolvida } \\
\text { pela Comunidade } \\
\text { Européia para comparar e } \\
\text { acompanhar os } \\
\text { indicadores de } \\
\text { aprendizagem entre os } \\
\text { países membros. }\end{array}$} & $\begin{array}{l}\text { Modelo concebido pela } \\
\text { UE, aceito e utilizado por } \\
\text { todos os países membros } \\
\text { para pesquisas entre } \\
\text { nações. }\end{array}$ & $\begin{array}{l}\text { Não aprofunda a } \\
\text { aprendizagem informal }\end{array}$ \\
\hline & & $\begin{array}{l}\text { Influência de outras } \\
\text { estruturas já vigentes, } \\
\text { como do ISCED (1997) }\end{array}$ & $\begin{array}{l}\text { Descarta a aprendizagem } \\
\text { casual }\end{array}$ \\
\hline \multirow{2}{*}{$\begin{array}{l}\text { CHEETHAM; } \\
\text { CHIVERS, } \\
2001\end{array}$} & \multirow{2}{*}{$\begin{array}{l}\text { Taxonomia dos métodos } \\
\text { de aprendizagem informal } \\
\text { profissional. }\end{array}$} & $\begin{array}{l}\text { Elaborado após ampla } \\
\text { revisão teórica; }\end{array}$ & \multirow[t]{2}{*}{$\begin{array}{l}\text { Não abordam as outras } \\
\text { formas de aprendizagem }\end{array}$} \\
\hline & & $\begin{array}{l}\text { Metodologia quali e } \\
\text { quantitativa suportam os } \\
\text { resultados; }\end{array}$ & \\
\hline \multirow[t]{5}{*}{$\begin{array}{l}\text { CONNER, } \\
2006\end{array}$} & \multirow{5}{*}{$\begin{array}{l}\text { Matriz que classifica as } \\
\text { oportunidades de } \\
\text { aprendizagem em } 5 \\
\text { categorias }\end{array}$} & \multirow[t]{5}{*}{ Uso de matriz } & $\begin{array}{l}\text { Definições mal concebidas } \\
\text { em detrimento do uso de } \\
\text { conceitos já desenvolvidos }\end{array}$ \\
\hline & & & $\begin{array}{l}\text { Exemplos não coerentes às } \\
\text { categorias }\end{array}$ \\
\hline & & & $\begin{array}{l}\text { A consultora não fundamenta } \\
\text { como chegou na matriz, } \\
\text { tampouco publicou artigos } \\
\text { acadêmicos que o } \\
\text { justificassem }\end{array}$ \\
\hline & & & $\begin{array}{l}\text { Uso de cinco categorias em } \\
\text { uma matriz de quatro vetores. }\end{array}$ \\
\hline & & & $\begin{array}{l}\text { A autora não é reconhecida ou } \\
\text { sequer é citada em artigos } \\
\text { acadêmicos }\end{array}$ \\
\hline
\end{tabular}

Quadro 5 - Análise das 3 estruturas vistas. Fonte: autor.

Como podemos perceber todas as estruturas de classificação possuem pontos positivos e negativos. Embora a estrutura proposta por Conner (2006) seja a mais criticada, baseamos nela inicialmente. Revisamos os conceitos e definições utilizados, bem como a lógica adotada na construção; e na seqüência, adotamos elementos das demais.

Existem diferentes definições para a aprendizagem formal, não-formal e informal "na academia, na literatura baseada em políticas e na literatura focada no praticante, e alguns autores discutem o tópico sem defini-los primeiro". (FULLER et al, 2003, p.4).

Segundo Billet (2001), há argumentos plausíveis para se evitar o uso dos termos formal e informal. No qual de certa maneira dá marcas arbitrárias para um processo que ocorre em diferentes - frequentemente em paralelo -, dimensões de formalidade e informalidade de acordo com o contexto (FULLER; UNWIN, 2004). 
Billett (op. cit.) e Colley et al (2003) rejeitam a concepção de que aprendizagem formal e informal são diferentes tipos de aprendizagem. Para os autores, todo o processo de aprendizagem pode ser caracterizado por atributos formais e informais. Assim, por exemplo, dentro de uma instituição de ensino a aprendizagem - caracterizada predominantemente como formal, por conta da característica da aula expositiva -, também se dá por meio da interação dos alunos.

Assim, uma maneira dos dois pensamentos coexistirem - dos que são a favor e contra a divisão -, é estabelecer um continuum, no qual os eventos de aprendizagem podem possuir diferentes intensidades de atributos formais e informais. Outra importante necessidade é de dividir ao máximo os grandes agrupamentos e se chegar à menor unidade possível de evento de aprendizagem. Assim, por exemplo, o curso superior poderá ser dividido em aulas expositivas, trabalhos em grupo, aulas de estudos de caso e discussão de avaliação, entre outros.

O impacto no modelo de Conner (2006) é a retirada do quinto eixo e a transformação de algo que era dicotômico em algo continuum baseado em dois extremos. O primeiro continuum pode continuar sendo o formal e o informal, entretanto o principal critério de alocação do evento de aprendizagem será a organização do evento de aprendizagem, ou seja, se é definida e promovida por um instrutor ou instituição de maneira estruturada, ou se é conduzida pelo aprendiz.

"A aprendizagem formal é institucionalmente patrocinada, baseada em sala de aula e altamente estruturada" (MARSICK; WATKINS, 1990). Enquanto que a "aprendizagem informal (...) pode ocorrer em instituições, mas não é normalmente baseada em sala de aula ou altamente estruturada". Na aprendizagem informal, como principais características, o "currículo é invisível” (DARRAH, 1996) e o "controle do aprendizado apóia-se principalmente nas mãos do aprendiz" (MARSICK; WATKINS, 1990).

Estes pontos são corroborados por Mocker e Spear (1982) quando afirmam que "aprendizes informais controlam os meios, mas não os objetivos de aprendizagem", enquanto que "aprendizes formais tem pouco controle sobre os objetivos ou meios de aprendizagem. 
Além disso, Cervero et al (1986) diferenciam a aprendizagem formal da informal. A primeira são "as atividades educativas que ocorrem sob a orientação de um instrutor, como seminários e cursos em universidades". A segunda, aprendizagem informal, são "as atividades educativas que ocorrem sem a ajuda de um instrutor, como consulta a dicionários, leitura de periódicos e procura por especialistas". Logo, outra característica que emerge das duas definições de Cervero et al (1986) é a participação de um instrutor no processo de aprendizagem.

No outro eixo, temos um continuum em relação à intencionalidade em aprender ou não. A aprendizagem casual ou ocasional (incidental learning) é pesquisada principalmente pelas autoras Marsick e Watkins (1990). Na aprendizagem casual, o que se aprende é um subproduto da realização de outra atividade que possui outro fim.

Em atividades ligadas à cultura, esporte e religião é muito difícil distinguir o que é e o que não é uma atividade de aprendizagem, assim como em atividades menos organizadas de autoaprendizagem. O exemplo dado no EUROSTAT (2006) é de um esportista que participa de uma competição e aumenta seu desempenho ao longo dele, mas como não era a intenção primária, a atividade não é considerada uma atividade de aprendizagem, já que o aprendizado foi apenas um subproduto e não algo intencional e buscado.

A visão de Marsick e Watkins (op. cit.) é binária, enquanto que para Eraut (2000) existem 3 níveis de intencionalidade. O primeiro deles é a aprendizagem deliberativa, ou seja, a aprendizagem ocorre de maneira consciente e planejada. O segundo é a aprendizagem reativa, na qual a aprendizagem é quase espontânea e os níveis de intencionalidade variam. Por fim, temos a aprendizagem implícita, na qual não há intenção de se aprender e também não se tem consciência da aprendizagem no momento em que ocorre.

$\mathrm{Na}$ revisão da literatura nenhum autor citou a possibilidade de existir a aprendizagem formal não intencional e quais seriam seus eventos. Conner (2006) foi a única a citar, entretanto partindo de teoria não concreta, os itens que ela classificou nesta combinação foram autoestudo, navegar na internet e exploração. O primeiro item, conforme apresentamos como teoria é nitidamente intencional; os demais, embora sejam não intencionais, nada tem de formal. 
Apresentaremos abaixo a descrição dos quadrantes resultantes da nova matriz e alguns exemplos:

- Aprendizagem conceitual (aprendizagem formal e intencional): são os eventos de aprendizagem cujo objetivo e realização são pouco influenciados pelo indivíduo, entretanto o que se aprende é o fim buscado por ele. Geralmente, os eventos tendem a ser mais estruturados e contam com o currículo visível e com a participação de um instrutor. Ex.: aulas expositivas, palestras, elearning, entre outros;

- Aprendizagem provocada (aprendizagem informal e intencional): são os eventos de aprendizagem que são promovidos pelo indivíduo, entretanto o currículo é invisível. Geralmente, os eventos são menos estruturados e os objetivos, embora possam ser planejados, ocasionarão em resultados diferentes ou além do escopo inicial. Ex.: feedback, mentoring, shadowing, role model, entre outros;

- Aprendizagem experiencial (aprendizagem informal e não intencional): é a aprendizagem casual propriamente dita. O que se aprende é um subproduto da realização de outras ações que possuem outros fins primários. O currículo é invisível e o que se aprende geralmente ocorre de forma inconsciente. Ex.: aprender por participar em projetos desafiadores, por trabalhar em equipes, por trabalhar com um especialista, entre outros;

- Aprendizagem experiencial induzida (aprendizagem formal e não intencional): são as oportunidades de aprendizagem cujo objetivo e realização são pouco influenciados pelo indivíduo; e, o que se aprende é um subproduto decorrente da participação neles. Geralmente, tendem a ser mais conduzidos por um instrutor e com o currículo direcionado. Ex.: jogos de empresas, resolução de casos, simuladores, entre outros.

Embora visualmente próximo ao modelo de Conner (ibid.), a estrutura proposta apresenta avanços significativos que facilitarão a classificação dos eventos dentro das aprendizagens levantadas, decorrentes do cruzamento: 


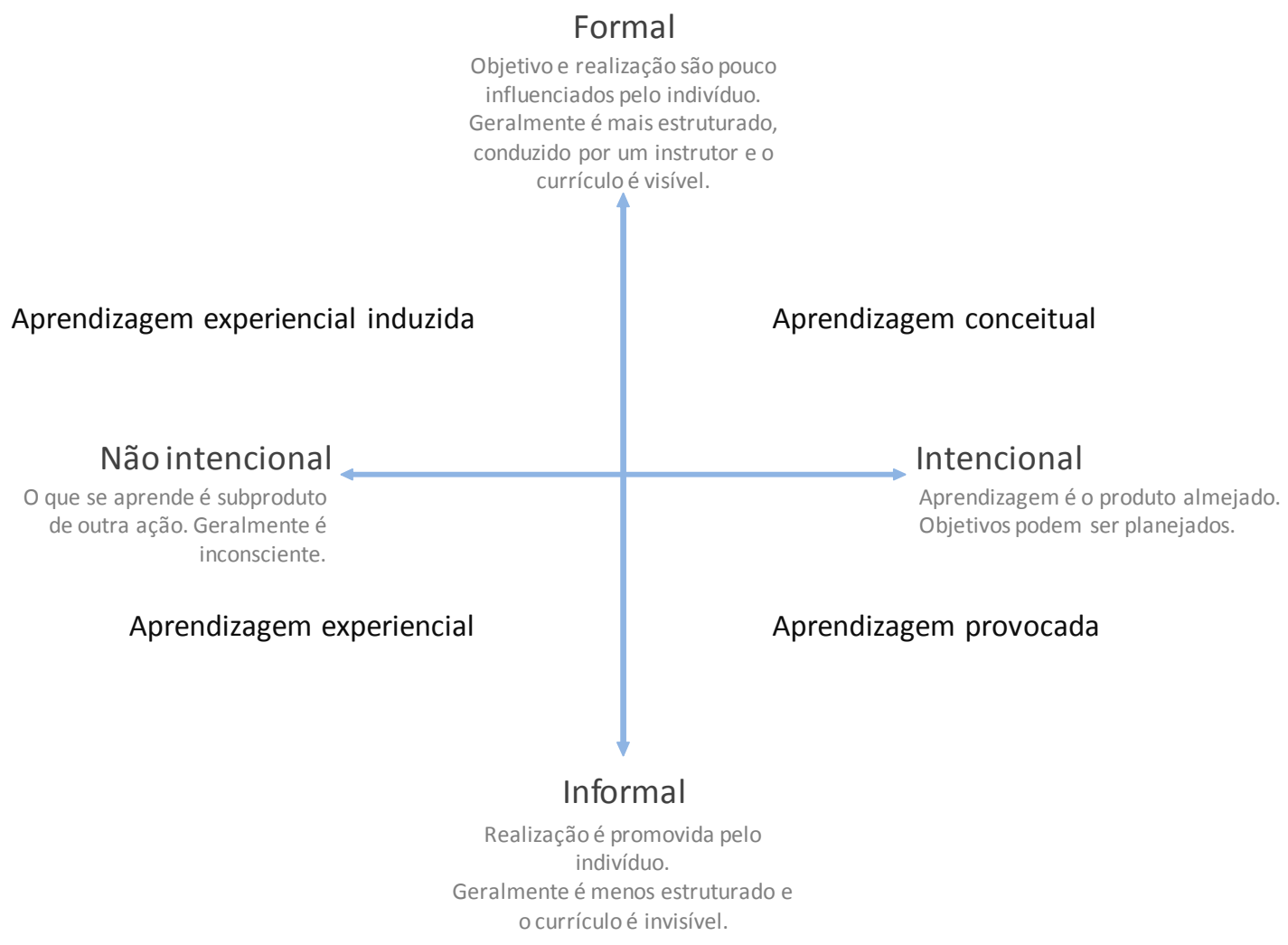

Figura 7 - Estrutura de Classificação de Eventos de Aprendizagem.

Aproveitamos os eventos levantados tanto no CLA (EUROSTAT, 2006), quanto na taxonomia de aprendizagem informal (CHEETHAM; CHIVERS, 2001) para classificá-los na estrutura proposta e testar a sua adequação. Como a taxonomia de aprendizagem informal é bem completa neste tipo, vamos complementá-la com os demais tipos encontrados no CLA. Além disso, a aprendizagem prática induzida foi complementada, pois ambas as pesquisas não citaram os itens que nela constam. O quadro abaixo apresenta como os itens foram classificados na nova estrutura. 


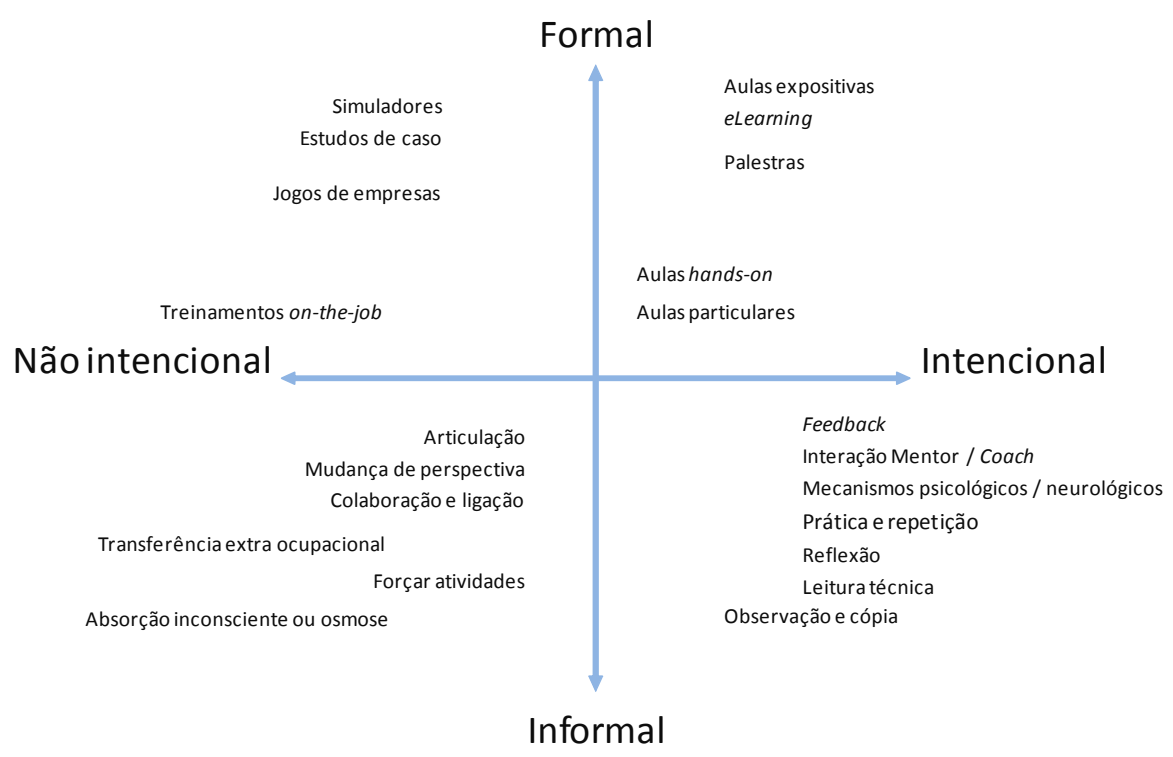

Figura 8 - Classificação das categorias de aprendizagem.

\subsection{Competência}

A epígrafe do primeiro capítulo do livro de Fleury e Fleury (2001) apresenta a seguinte frase de Le Boterf (1998): "Competência, um conceito em construção". Desde então muito se produziu na academia, bem como se aplicou na prática. Entretanto, por outro lado, a frase ainda é válida nos dias de hoje.

Dias et al (2008) identificaram em sua pesquisa bibliométrica no Brasil que o conceito de competências é ainda um tópico multidisciplinar pouco tangível, diferenciado e homogêneo e cuja articulação e aplicação são complexas. Somado a isso, temos que "a dinâmica e mobilidade da ênfase em que a noção de competência é pensada e aplicada no contexto das organizações e do ambiente socioeconômico" (Ibid., p.25).

Como exemplo de sua heterogeneidade, Weinert (2001) enumerou nove diferentes interpretações ou definições encontradas na literatura para competências: capacidade cognitiva geral; habilidade cognitiva especializada; modelo de desempenho de competência; modelo de desempenho de competência modificado; auto-conceito subjetivo e objetivo; tendências de ação motivadas; competência de ação; competências-chave; metacompetência. 
Além disso, três dominantes abordagens se desenvolveram de forma independente: a americana, a do Reino Unido, e mais recentemente da França e Alemanha (Le DEIST \& WINTERTON, 2005).

Nos Estados Unidos, país onde surgiu o termo, o conceito de competência foi empregado pela primeira vez por White (1959) como sendo uma característica de personalidade associada com desempenho superior e alta motivação - o que mais tarde seria aprimorado para uma interação efetiva do indivíduo com o ambiente. McClelland (1973) denomina competência como sendo uma característica subjacente da pessoa no exercício de uma determinada tarefa. Le Deist e Winterton (2005) etiquetam a abordagem americana como comportamental.

O americano Parry (1996, p.49) apresenta uma definição oriunda de sugestões de diversos especialistas em desenvolvimento de recursos humanos (HRD) que comparecerem a uma conferência em Johannesburg, África do Sul, em 1995. Segundo o autor:

\footnotetext{
"Competência é um cluster de conhecimento, habilidades e atitudes (K, S, A) relacionados que afetam a maior parte do trabalho (papel ou responsabilidade) de alguém, que correlaciona com o desempenho no trabalho, que pode ser mensurado contra padrões bem aceitos, e que podem ser aprimorada por meio de treinamento e desenvolvimento".
}

No Reino Unido temos a abordagem funcional. Por conta das deficiências de formação de habilidades, o Governo foi levado a desenvolver um sistema nacional de qualificação baseada em competências (o NVQs - National Vocational Qualifications, na Inglaterra; e, o SVQs Scottish Vocational Qualifications, na Escócia). O processo de desenvolvimento contou com a participação de empresas e de sindicatos para se definir as qualificações de cada setor.

A definição de competências utilizada no Reino Unido é de "capacidade de desempenhar atividades em ocupações no trabalho, para os padrões esperados de emprego" (Investors in People, 1995, p.41 apud Ibid.). O que mais tarde seria revisada para "a capacidade de aplicar conhecimento, compreensão e habilidades no desempenho de padrões requeridos no emprego. Inclui resolução de problemas e encontrar demandas de mudança" (Beaumont, 1996 apud Ibid.).

Enquanto que nos Estados Unidos temos uma compreensão de competências baseada em inputs - cluster de conhecimento, habilidades e atitudes que afetam a capacidade do indivíduo 
em desempenhar -, no Reino Unido, competências são vistos como outputs - trabalhadores demonstram competências ao passo que atendem ou superam demandas do trabalho (PARRY, 1996).

$\mathrm{Na}$ França, Alemanha e Áustria temos uma abordagem mais multidimensional, holística e compreensiva. Principalmente os dois primeiros influenciaram o conceito de competências nos demais países europeus na década de 90.

Competência à la française também é vista como "a entrega da pessoa para a organização" (DUTRA, 2002, p.129) e vai além do conceito de qualificação, referindo-se "à capacidade de a pessoa assumir iniciativas, ir além das atividades prescritas, ser capaz de compreender e dominar novas situações no trabalho, ser responsável e ser reconhecido por isso" (ZARIFIAN, 1994, p.111 apud FLEURY; FLEURY, 2001, p.19).

Em busca de uma definição, Fleury e Fleury (ibid., p.20) analisam o que seria competência à luz da corrente francesa:

\footnotetext{
"A competência do indivíduo não é um estado, não se reduz a um estado, não se reduz a um conhecimento ou know-how específico. Le Boterf (1994) situa a competência numa encruzilhada, com três eixos formados pela pessoa (sua biografia, socialização), por sua formação educacional e por sua experiência profissional. A competência é o conjunto de aprendizagens sociais comunicacionais nutridas à montante pela aprendizagem, formação, e à jusante pelo sistema de avaliações. Segundo ainda este autor, competência é um saber agir responsável e que é reconhecido pelos outros. Implica saber como mobilizar, integrar e transferir conhecimentos, recursos e habilidades, num contexto profissional e determinado".
}

A partir da definição de Le Boterf (ibid.), Fleury e Fleury (op.cit.) desenvolvem sua definição adicionando a questão da agregação de valor para a organização e ao indivíduo. Logo, temos a definição de competências que utilizaremos neste trabalho:

“Competência é um saber agir responsável e reconhecido, que implica mobilizar, integrar, transferir conhecimentos, recursos, habilidades, que agreguem valor econômico à organização e valor social ao indivíduo"

\subsection{Tipologia de Competências}


Para facilitar o estudo da relação com os eventos de aprendizagem, buscou-se reduzir competência em partes. Assim, foram encontradas na literatura vinte e oito tipologias de competências, os quais são apresentados no quadro abaixo e analisados no próximo item.

\begin{tabular}{|c|c|}
\hline Autor & Tipos de Competências \\
\hline Boyatzis (1982) & $\begin{array}{l}\text { Meta e gestão da ação, Liderança, Gestão de recursos } \\
\text { humanos, Direção subordinadas e Outras }\end{array}$ \\
\hline $\begin{array}{l}\text { YUKL (1989 apud Nordhaug, } \\
\text { 1998) }\end{array}$ & cnicas, Interpessoais e Conceituais \\
\hline $\begin{array}{l}\text { Schroder (1989 apud } \\
\text { Cockerill, 1994) }\end{array}$ & $\begin{array}{l}\text { Busca de informação, Formação de conceitos, Flexibilidade } \\
\text { conceitual, Busca interpessoal, Gerir interação, Orientação } \\
\text { para o desenvolvimento, Impacto, Autoconfiança, } \\
\text { Apresentação, Orientação pró-ativa, Orientação para } \\
\text { realização. }\end{array}$ \\
\hline Spencer \& Spencer (1993) & $\begin{array}{l}\text { Executivos: Pensamento Estratégico, Liderança para } \\
\text { mudança, Gestão de relacionamentos. } \\
\text { Gerentes: Flexibilidade, Implementação de mudanças, } \\
\text { Inovação empreendedora, Compreensão interpessoal, } \\
\text { Fortalecimento da equipe, Facilitação do time, Portabilidade. } \\
\text { Operacionais: Flexibilidade, Motivação para buscar } \\
\text { informações e capacidade de aprender, Motivação para } \\
\text { realização, Motivação ao Trabalho sobre Pressão de Tempo, } \\
\text { Colaboração, Serviço orientado ao cliente. }\end{array}$ \\
\hline 994) & $\begin{array}{l}\text { Open thinking (flexibilidade intelectual e mente aberta), } \\
\text { Personal impact (impacto pessoal, autoconfiança e disposição } \\
\text { para a ação); Empowering (autonomia, orientação para o } \\
\text { desenvolvimento e realizações); Networking (orientação para } \\
\text { o estabelecimento de redes de relacionamentos) }\end{array}$ \\
\hline $\begin{array}{l}\text { Cheetham e Chivers (1996; } \\
\text { 1998) }\end{array}$ & getência \\
\hline Parr & $\begin{array}{l}\text { Comunicação e Interpessoal, Supervisão e Liderança, } \\
\text { Administrativa e de Condução de Tarefas, Cognitiva e } \\
\text { Conceitual, e Outras. }\end{array}$ \\
\hline ASTD apud Parry (1996) & Intelectuais, Interpessoais, Negócio e Técnicas \\
\hline Nordhaug (1998) & $\begin{array}{l}\text { Meta competência, Competência geral da indústria, } \\
\text { Competência intraorganizacional, Competência padrão }\end{array}$ \\
\hline
\end{tabular}




\begin{tabular}{|c|c|}
\hline Autor & Tipos de Competências \\
\hline & $\begin{array}{l}\text { técnica, Competência técnica comercial, Competência } \\
\text { idiossincrática técnica. }\end{array}$ \\
\hline Zarifian (1999) & $\begin{array}{l}\text { Sobre processos, Técnicas, Sobre a organização, de Serviços } \\
\text { e Sociais }\end{array}$ \\
\hline $\begin{array}{ll}\text { MCI } & \text { (apud REYNOLDS, } \\
\text { 1999) }\end{array}$ & $\begin{array}{l}\text { Agir assertivamente, Agir com ética, Agir estrategicamente, } \\
\text { Comunicar, Desenvolver equipes, Foco no resultado, } \\
\text { Gerenciar a si próprio, Influenciar pessoas, Pesquisar } \\
\text { informações e Refletir e tomar decisões }\end{array}$ \\
\hline Fleury e Fleury (2001) & Negócio, Técnico-profissionais, Sociais \\
\hline Rabaglio (2001) & Técnicas e Comportamentais \\
\hline OIT (2002) & $\begin{array}{l}\text { - Alemanha: Técnica, metodológica, social e participativa; } \\
\text { - Austrália: Industriais, que ultrapassam a indústria, gerais e } \\
\text { chave; } \\
\text { - Canadá: qualificações acadêmicas, de desenvolvimento } \\
\text { pessoal, e para trabalhar em equipe; } \\
\text { - Espanha: capacidade técnica, organizativa, de relação e de } \\
\text { respostas às contingências; } \\
\text { - Estados Unidos: práticas e fundamentais; } \\
\text { - México: básicas, genéricas e específicas; } \\
\text { - Reino Unido: específicas do setor, genéricas e essenciais. }\end{array}$ \\
\hline OECD (2002) & $\begin{array}{l}\text { Agir de forma autônoma, usar ferramentas interativamente, } \\
\text { Interagir em grupos heterogêneos }\end{array}$ \\
\hline Domingues (2003) & Teóricas, Práticas, Relacionais e Estratégicas \\
\hline Fonseca (2003) & Gerenciais, Técnicas e Sociais \\
\hline Marcket apud Mitchell (2004) & Técnicas e Comunicativas \\
\hline Le Deist e Winterton (2005) & $\begin{array}{l}\text { Alemanha: domínio/assunto, pessoais e sociais } \\
\text { Áustria: cognitivo, social, e pessoal } \\
\text { França: teóricas, práticas e sociais/comportamentais }\end{array}$ \\
\hline Le Deist e Winterton (ibid.) & Cognitiva, funcional, social e metacompetência \\
\hline
\end{tabular}

Boyatzis (1982) foi a referência mais antiga encontrada na revisão bibliográfica a tratar de tipologia de competências. Além de listar as competências do "gestor competente", o autor apresentou clusters de competências distribuídas segundo o nível do gestor, que pode ser gestor ingressante, de média gerência e executivo. O quadro abaixo mostra os clusters: 


\begin{tabular}{|c|c|c|}
\hline $\begin{array}{l}\text { Para o nível de gestores } \\
\text { ingressantes }\end{array}$ & $\begin{array}{l}\text { Para o nível de média } \\
\text { gerência }\end{array}$ & $\begin{array}{l}\text { Para o nível de gestores } \\
\text { executivos }\end{array}$ \\
\hline \multirow[t]{3}{*}{$\begin{array}{l}\text { Cluster: Meta e gestão da } \\
\text { ação: Uso diagnóstico de } \\
\text { conceitos; } \\
\text { eficiente, pró-atividade }\end{array}$} & $\begin{array}{l}\text { Cluster: Meta e gestão da } \\
\text { ação: Preocupação com o } \\
\text { impacto; Uso diagnóstico de } \\
\text { conceitos; Orientação } \\
\text { eficiente, pró-atividade }\end{array}$ & $\begin{array}{l}\text { Cluster: Meta e gestão da } \\
\text { ação: Preocupação com o } \\
\text { impacto; Uso diagnóstico de } \\
\text { conceitos; Orientação } \\
\text { eficiente, pró-atividade }\end{array}$ \\
\hline & $\begin{array}{l}\text { Cluster } \\
\text { Conceitualização, raciocínio } \\
\text { lógico, autoconfiança, uso de } \\
\text { apresentação oral }\end{array}$ & $\begin{array}{l}\text { Cluster } \\
\text { Conceitualização, raciocínio } \\
\text { lógico, autoconfiança, uso de } \\
\text { apresentação oral }\end{array}$ \\
\hline & $\begin{array}{l}\text { Cluster de gestão de recursos } \\
\text { humanos: auto-avaliação } \\
\text { acurada, gestão de processos } \\
\text { em grupo, Consideração } \\
\text { positiva, Uso de poder } \\
\text { socializado }\end{array}$ & \\
\hline \multicolumn{3}{|l|}{$\begin{array}{l}\text { Cluster de direção de } \\
\text { subordinados: desenvolver os } \\
\text { outros, Espontaneidade, Uso } \\
\text { de poder unilateral }\end{array}$} \\
\hline $\begin{array}{l}\text { Outras competências: Auto- } \\
\text { avaliação acurada, auto- } \\
\text { controle, Resistência e } \\
\text { adaptabilidade, uso de poder } \\
\text { socializado }\end{array}$ & $\begin{array}{l}\text { Outras } \\
\text { desenvolver os outros, } \\
\text { objetividade perceptual, } \\
\text { espontaneidade, resistência e } \\
\text { adaptabilidade }\end{array}$ & $\begin{array}{l}\text { Outras competências: } \\
\text { Desenvolver os outros, gerir } \\
\text { processos em grupo, } \\
\text { objetividade perceptual }\end{array}$ \\
\hline
\end{tabular}

Quadro 7 - Competências relevantes para o desempenho e eficácia em relação às demandas de trabalho: vários níveis de trabalhos em gestão. (BOYATZIS, 1982, p.226-227).

Os quatro clusters foram nomeados como: meta e gestão da ação, liderança, gestão de recursos humanos, direção subordinadas e outras. É válido mencionar que as competências que formam os clusters podem ser mais ou menos presentes conforme o nível do gestor.

Nordhaug (1998) destaca que a tipologia de competências do indivíduo mais difundida foi desenvolvida por Yukl (1989) e se subdivide em três grupos: competências técnicas, interpessoais e conceituais. As competências técnicas são as competências relacionadas à tarefa, ou seja, como executar métodos e processos, ou mesmo, utilizar alguma ferramenta. As 
competências interpessoais são as competências atreladas às pessoas, ou seja, a capacidade de relacionamento, comunicação e cooperação, entre outros. Por fim, as competências conceituais são aquelas atreladas às ideias e conceitos, ou seja, a criatividade, a capacidade analítica, a eficiência em resolver problemas, bem como a capacidade de reconhecer oportunidades e problemas potenciais.

Schroder (1989 apud Cockerill, 1994) apresenta as competências de uma maneira menos agrupada, logo mais específica. Assim, o autor elencou onze tipos de competências:

- Busca de informação: trabalhar com diversos tipos de informações e ampla variedade de fontes para a tomada de decisão;

- Construção de conceitos: construir estruturas ou modelos, elaborar conceitos, hipóteses e ideias com base na informação; ter consciência dos padrões, tendências e relações de causa-efeito;

- Flexibilidade conceitual: identificar alternativas factíveis e múltiplas opções no planejamento e na tomada de decisões;

- Busca interpessoal: usar questões abertas e paráfrases para compreender ideias, conceitos e sentimentos dos outros; perceber os eventos, problemas e oportunidades a partir da perspectiva dos outros;

- Gestão de equipes: envolver os demais e ser capaz de montar equipes cooperativas nas quais os membros se sintam valorizados e fortalecidos;

- Orientação para o desenvolvimento: criar um clima positivo em que as pessoas estejam conscientes de seus pontos fortes e limitações. Providenciar orientação, treinamento e outros recursos para elevar o desempenho;

- Impacto pessoal: usar variedade de métodos (argumentos persuasivos, modelos de comportamento, símbolos e alianças) para obter apoio para suas ideias, valores e estratégias;

- Autoconfiança: manter sua posição em determinados temas. Tomar decisões sem hesitar e demonstrar confiança no sucesso de suas ações;

- Apresentação de ideias: apresentar ideias com clareza; despertar o interesse nos outros para que possam compreendê-las; usar recursos técnicos (simbólicos e visuais) com eficácia;

- Orientação proativa: estruturar os trabalhos, implementar planos e ideias e assumir a responsabilidade por todos os aspectos da situação; 
- Orientação para realização: possuir elevados padrões de desempenho, estabelecer metas ambiciosas e factíveis, visando a maximizar resultados.

Spencer e Spencer (1993) adicionaram a diferença de competências entre os níveis, já que um executivo pode apresentar uma competência de execução mais complexa, ou até mesmo uma inexistente como equivalente no nível operacional.

As competências que os executivos deveriam apresentar são:

- Pensamento estratégico: capacidade de perceber tendências de mudança no ambiente, oportunidades de mercado, ameaças, forças e fraquezas da organização, bem como de identificar a resposta estratégica necessária;

- Liderança para mudar: capacidade de comunicar a estratégia organizacional, estimular o envolvimento e o comprometimento dos stakeholders, estimular a inovação contínua e direcionar esforços para implementação frequente de mudanças;

- Gestão de relacionamentos: capacidade de estabelecer relacionamentos e exercer influência sobre aqueles cuja cooperação é fundamental para o sucesso organizacional (ex.: governo, fornecedores, entre outros.).

Para a gerência, são esperadas as seguintes competências:

- Flexibilidade: capacidade de alterar processos e estruturas gerenciais para implementação de estratégias de mudança organizacional;

- Gerenciamento de mudanças: capacidade de comunicar as necessidades de mudança organizacional, implementar e gerenciar mudanças, incluindo comunicação, treinamento e implantação de processos facilitadores;

- Inovação empreendedora: motivação para inovar em produtos, serviços e processos;

- Compreensão interpessoal: capacidade de entender e avaliar as contribuições alheias;

- Fortalecimento da equipe: capacidade de compartilhar informações e ideias, estimular o desenvolvimento profissional da equipe, delegar e motivar empregados a assumir responsabilidades maiores, retribuir melhorias de desempenho, expressar expectativas com relação aos subordinados e fornecer feedback; 
- Facilitação de propósitos: capacidade de gerenciar equipes para atingir um objetivo comum, incluindo o estabelecimento de metas e papéis para os membros, o estímulo da participação e a mediação de conflitos;

- Adaptabilidade e gestão da cultura: capacidade de adaptar-se rapidamente a mudanças para ambientes estrangeiros, incluindo o entendimento, interpretação e adaptação à cultura local.

E, por fim, os profissionais mais operacionais deveriam apresentar:

- Flexibilidade: predisposição para entender mudanças mais como oportunidades do que como ameaças;

- Motivação para a busca de informações e capacidade de aprendizagem: entusiasmo por oportunidades de aprendizagem de novas técnicas e habilidades pessoais;

- Motivação para realização: ímpeto pela inovação e aperfeiçoamento contínuos;

- Trabalho sob pressão de tempo: capacidade de administrar o stress e trabalhar sob a demanda crescente de novos produtos e serviços;

- Colaboração: capacidade de cooperar com colegas em equipes multidisciplinares, incluindo relacionamento interpessoal, comprometimento organizacional e adoção de expectativas positivas em relação aos outros;

- Orientação para o cliente: genuíno desejo de ser útil aos outros, incluindo a capacidade de identificar e suprir as necessidades dos clientes.

Sparrow e Bognanno (1994) identificaram no sistema de gestão por competências da British Petroleum o modelo "OPEN competencies", tal sigla remete às primeiras letras dos quatro grupos identificados a partir das 60 competências observadas no processo de elaboração. Os grupos são:

- Open thinking: flexibilidade intelectual e mente aberta;

- Personal impact: impacto pessoal, autoconfiança e disposição para a ação;

- Empowering: autonomia, orientação para o desenvolvimento e realizações;

- Networking: orientação para o estabelecimento de redes de relacionamentos.

Cheetham e Chivers $(1996 ; 1998)$ desenvolveram um modelo holístico de competência profissional que consiste de cinco grupos interconectados. 
- Competência funcional: é a capacidade de desempenhar uma gama de atividades relacionadas ao trabalho efetivamente para produzir resultados específicos. São as habilidades e o saber-como;

- Competência pessoal ou comportamental: é a capacidade de adotar comportamentos apropriados e observáveis em situações relacionadas ao trabalho;

- Competência cognitiva/de conhecimento: é a posse de conhecimento relacionado ao trabalho apropriado e a capacidade de colocar isso em isso efetivo.

- Competências éticas/de valores: é a posse de valores pessoais e profissionais e a capacidade de fazer julgamentos baseados em situações relacionadas ao trabalho;

- Metacompetências: são as competências que desenvolvem e reforçam outras competências, como por exemplo, a capacidade de refletir e de aprender.

Embora alguns trabalhos (por exemplo: RIBEIRO; GUIMARÃES, 1999) apontem que Parry (1996) divide competências em Soft competencies e Hard competencies, a consulta na fonte original relata que Parry (ibid., p.50) apenas cita que "muitos estudos também fazem a distinção entre competências soft e hard", e que embora ele acredite que traços de personalidade, valores e estilos (soft) possam contribuir para o sucesso empresarial, o autor duvida que possam ser passíveis de mudanças.

Da mesma maneira, Soft skills e Hard skills são citados em inúmeros trabalhos, entretanto nenhum deles apresenta o autor seminal desta divisão, apenas dizem ser "a mais citada". Entretanto, há distinção entre o que Parry (ibid.) chama de soft competencies para o que os demais (exemplo: DOUGLAS, 2002; ELMUTI, 2004) chamam de Soft skills. Esta segunda estaria mais atrelada às capacidades inter e intrapessoais, como por exemplo, a negociação, a gestão de equipes e a comunicação.

O que Parry (ibid.) aponta em seu artigo como sendo mais próximo de uma tipologia de competências é o agrupamento de 10 estudos $^{13}$, o qual cria 5 categorias para reuni-los:

\footnotetext{
${ }^{13}$ A saber: American Management Association (com McBer\&Co), AT\&T (Pat McLagan), Martin Marietta, Ford Motor Co. (assessment lab), Eastman Kodak Co., Henley Management College (United Kingdom), Australian National Training Authority, The Principal Financial Group (com Personnel Decisions Intl.), Public Service Eletric \& Gas (of New Jersey), Training House.
} 
Comunicação e Interpessoal, Supervisão e Liderança, Administrativa e de Condução de Tarefas, Cognitiva e Conceitual, e Outras.

Outra categorização que pode ser extraída do mesmo trabalho é proveniente da matriz de competências de HRD (id., 1999, p.51). Nesta matriz, desenvolvida pela American Society of Training and Development (ASTD), há quatro agrupamentos de competências: Intelectuais, Interpessoais, Negócio e Técnicas. O primeiro reúne competências cognitivas de processamento da informação, o segundo reúne competências de relacionamento interpessoal, o terceiro reúne competências para compreensão da indústria e do negócio em si, e o último reúne competências técnicas da função.

Nordhaug (1998) apresenta uma matriz de tipologia de competências, representada abaixo, no qual o primeiro eixo baseia-se na especificidade da tarefa e o segundo eixo baseia-se na especificidade da indústria e da firma. No caso da tarefa, a baixa especificidade relaciona-se ao conjunto de competências "que não é particularmente relevante para uma tarefa concreta, mas é relevante para uma ampla gama de tarefas" (ibid., p.11). No caso da firma, uma competência de alta especificidade terá "nenhum potencial de valor para outros empregadores" (ibid., p. 12); já uma competência não específica poderá ser ainda específica de uma indústria ou geral.

\begin{tabular}{|l|l|l|l|}
\hline \multirow{2}{*}{$\begin{array}{l}\text { Especificidade da } \\
\text { Tarefa }\end{array}$} & \multicolumn{3}{|c|}{ Especificidade da Firma } \\
\cline { 2 - 4 } & Baixa & Alta \\
\cline { 2 - 4 } & Baixa & Alta & \\
\hline Baixa & I- Meta competência & $\begin{array}{l}\text { II- Competência geral } \\
\text { da indústria }\end{array}$ & $\begin{array}{l}\text { III- Competência } \\
\text { intraorganizacional }\end{array}$ \\
\hline Alta & $\begin{array}{l}\text { IV- Competência } \\
\text { padrão técnica }\end{array}$ & $\begin{array}{l}\text { V- Competência } \\
\text { técnica comercial }\end{array}$ & $\begin{array}{l}\text { VI- Competência } \\
\text { idiossincrática } \\
\text { técnica }\end{array}$ \\
\hline
\end{tabular}

Pelo encontro dos dois eixos, temos os seguintes tipos de competência: 
- Metacompetência: compreende grande variedade de competências que podem ser usadas em diversas indústrias. São fundamentais, básicas e gerais. Exemplo: capacidades analíticas, criatividade, relacionamento interpessoal, entre outros;

- Competência geral da indústria: segundo Yukl (1989), cada indústria tem características únicas econômicas, tecnológicas e relacionadas ao mercado. Da mesma forma, o networking e as relações recíprocas comerciais criadas só fazem sentido quando se atua nesta mesma indústria. Exemplo: compreensão do funcionamento da indústria, percepção da reação da concorrência, entre outros;

- Competência intraorganizacional: seria a metacompetência adaptada para a cultura da organização, ou exemplificando em outras palavras, não basta apenas entender de liderança, é preciso saber caminhar pela sua arena política. Exemplo: capacidade de mobilizar os recursos específicos da organização, compreender as dinâmicas políticas, a estratégia e metas;

- Competência padrão técnica: são as competências orientadas para a operação/tarefa de aplicação geral para várias indústrias. Exemplo: programação computacional, elaboração de um orçamento geral entre outros;

- Competência técnica comercial: são as competências de tarefas específicas de uma indústria transferíveis entre as firmas do mesmo setor. Podem somente ser usadas para completar uma ou poucas tarefas de trabalho limitadas. Exemplo: competência de operários na montagem de veículos e aeronaves, competências técnicas de cabeleireiros e bartenders;

- Competência idiossincrática técnica: são as competências que podem ser aplicadas para resolver uma única ou muito poucas tarefas em uma única firma; incluem conhecimentos e habilidades relacionadas com a operação de uma única tecnologia e rotina. Exemplo: capacidade de operar um sistema de dados específico da empresa; capacidade de operar uma máquina específica da empresa, entre outros.

Pela análise de Zarifian (1999), é possível identificar cinco tipos de competências:

- Competências sobre processos: são os conhecimentos do indivíduo sobre os processos e fluxos de trabalho;

- Competências técnicas: são os conhecimentos do indivíduo relacionados ao domínio de ferramentas e máquinas; 
- Competências sobre a organização: são as competências sobre a organização. É a compreensão dos parâmetros e princípios de funcionamento da organização; é saber participar de sua definição quando o contexto exige;

- Competências de serviços: é a compreensão do impacto, direta ou indiretamente, no modo como o produto (bem ou serviço) executado trará benefícios úteis a seus destinatários/clientes;

- Competências sociais e do saber ser: é a conduta do indivíduo diante de um dado ambiente, ou seja, seus comportamentos e atitudes. Os comportamentos são manifestos nos campos da autonomia, da tomada de responsabilidade e da comunicação.

Sobre as duas primeiras competências o autor as compara e conclui que "a competência profissional é mais do que antes centrada nos processos (e menos na condução individual das máquinas) e que esta aumenta e se aprofunda" (ibid., p.153). As competências técnicas têm tido sua importância diminuída, uma vez que a automatização vem crescendo e os computadores passam a pilotar as máquinas.

O Management Charter Initiative (MCI apud REYNOLDS, 1999), órgão do Reino Unido, identificou 10 grupos de competências gerenciais. É válido lembrar que em cada grupo ainda consta uma ampla gama de competências, que devido a sua especificidade, preferiu-se aqui não as detalhar. Os grupos são:

- Agir assertivamente: agir com segurança e assumir responsabilidades e o papel de liderança;

- Agir eticamente: identificar as responsabilidades éticas e agir conforme as regras;

- Agir estrategicamente: compreender o ambiente e planejar o futuro da organização;

- Comunicar: fazer com que a informação alcance o seu destino da maneira mais clara possível, tanto em direção ao receptor, quanto pelo levantamento de informações; Propiciar a comunicação;

- Desenvolver equipes: liderar as pessoas em direção dos resultados e desenvolvê-las;

- Foco em resultados: manter o foco em resultados e procurar fazer as coisas da melhor maneira possível;

- Gerenciar a si próprio: promover o próprio desenvolvimento;

- Influenciar pessoas: criar e utilizar diferentes estratégias para influenciar pessoas; 
- Pesquisar informações: buscar informações em múltiplas fontes, verificando a validade e confiabilidade das mesmas;

- Refletir e tomar decisões: analisar e tomar decisões realistas para cada situação.

Fleury e Fleury (2001, p. 24) categorizaram as competências do indivíduo em três blocos:

- Competências de negócio: são as competências relacionadas à compreensão do negócio, objetivos na relação com mercado, clientes e competidores, e com o ambiente político e social;

- Competências técnico-profissionais: são as competências específicas para uma determinada operação, ocupação ou atividade;

- Competências sociais: são as competências necessárias para interagir com as pessoas.

Rabaglio (2001), por sua vez, divide as competências individuais em dois tipos:

- Competências técnicas: são as competências envolvidas na realização propriamente dita de uma tarefa;

- Competências comportamentais: são os requisitos psicológicos esperados de um indivíduo ao realizar uma determinada tarefa.

Com uma visão mais governamental, o relatório elaborado pela Organização Internacional do Trabalho (OIT, 2002) elenca as diversas tipologias de competências profissionais utilizadas em seus países para atuar em questões ligadas ao trabalho, emprego e qualificação. O quadro abaixo apresenta as competências, bem como as suas respectivas definições, adotadas na Alemanha, Austrália, Canadá, Espanha, Estados Unidos, México e Reino Unido.

\begin{tabular}{|l|l|}
\hline País & Definições \\
\hline Alemanha & $\begin{array}{l}\text { - Competência técnica: Possui competência técnica aquele que domina, como } \\
\text { especialista, as tarefas e conteúdos de seu campo de trabalho, e os conhecimentos } \\
\text { e habilidades necessárias para isto; } \\
\text { - Competência metodológica: Possui competência metodológica aquele que } \\
\text { sabe aplicar o procedimento adequado às tarefas encomendadas e às disfunções } \\
\text { que se apresentem; que encontra, de maneira independente, formas de solucionar } \\
\text { problemas e que transfere adequadamente as experiências adquiridas a outras }\end{array}$ \\
\hline
\end{tabular}




\begin{tabular}{|c|c|}
\hline País & Definições \\
\hline & $\begin{array}{l}\text { situações do trabalho; } \\
\text { - Competência social: Possui competência social aquele que sabe colaborar com } \\
\text { outras pessoas de forma comunicativa e construtiva, e mostra um comportamento } \\
\text { orientado para o grupo e para o entendimento interpessoal; } \\
\text { - Competência participativa: Possui competência participativa aquele que sabe } \\
\text { participar na organização de seu local de trabalho e também de sua área } \\
\text { profissional, sendo capaz de organizar, decidir e aceitar responsabilidades. }\end{array}$ \\
\hline Austrália & $\begin{array}{l}\text { - Competências industriais: são as que se referem a uma área ocupacional } \\
\text { específica; } \\
\text { - Competências que ultrapassam a indústria: são as competências transversais } \\
\text { ou comuns a várias áreas ocupacionais; } \\
\text { - Competências gerais: estas competências também são chamadas genéricas e } \\
\text { têm como propósito assinalar o desempenho do trabalhador. Entre elas se } \\
\text { incluem as de higiene e segurança; } \\
\text { - Competências-chave: também entendidas como competências essenciais, não } \\
\text { somente para a participação efetiva do trabalhador ante novas situações, mas } \\
\text { também para as atividades essenciais na vida adulta em geral. Estas } \\
\text { competências são 7, que se enumeram em seguida: obtenção, análise e } \\
\text { organização da informação; comunicação de ideias e informação; planejamento e } \\
\text { organização de atividades; trabalho em equipe; aplicação de princípios } \\
\text { matemáticos e técnicos; solução de problemas; uso de tecnologia. }\end{array}$ \\
\hline Canadá & $\begin{array}{l}\text { - Qualificações acadêmicas: habilidades para comunicar-se de maneira efetiva } \\
\text { no local de trabalho (falar, ler e escrever); resolver problemas de maneira } \\
\text { analítica, utilizando a matemática e outras disciplinas relacionadas; e aprender de } \\
\text { forma contínua durante toda a vida profissional; } \\
\text { - Qualificações de desenvolvimento pessoal: demonstrar a motivação para } \\
\text { progredir na empresa, mediante atitudes e comportamentos positivos, auto- } \\
\text { estima, confiança e disposição para aceitar o desafio que apresentam as } \\
\text { mudanças no âmbito profissional; } \\
\text { - Qualificações para trabalhar em equipe: habilidades para trabalhar como } \\
\text { membro de uma equipe, entender a importância do trabalho em um contexto } \\
\text { amplo da organização, fazer planos e tomar decisões de forma conjunta. }\end{array}$ \\
\hline Espanha $^{14}$ & - Capacidades técnicas: estão relacionadas com o saber e o saber fazer próprios \\
\hline
\end{tabular}

\footnotetext{
${ }^{14} \mathrm{Na}$ Espanha, além dos grupos de capacidades citados, há uma descrição de competências para cada um dos 134 certificados profissionais mapeados.
} 


\begin{tabular}{|c|c|}
\hline País & Definições \\
\hline & $\begin{array}{l}\text { de uma ocupação; } \\
\text { - Capacidades organizativas: referem-se à coordenação das diversas atividades } \\
\text { de uma ocupação; } \\
\text { - Capacidade de relação: tem a ver com as relações e os procedimentos da } \\
\text { instituição ou empresa quanto à organização do trabalho e a integração do } \\
\text { trabalhador no contexto do trabalho; } \\
\text { - Capacidade de resposta às contingências: tem a ver com as situações novas } \\
\text { nas quais o trabalhador precisa dar respostas, agindo com responsabilidade e } \\
\text { autonomia. }\end{array}$ \\
\hline $\begin{array}{l}\text { Estados } \\
\text { Unidos }\end{array}$ & $\begin{array}{l}\text { - Competências práticas: existem cinco categorias de competências práticas } \\
\text { para o saber fazer: Recursos: identificação, organização, projeção e designação } \\
\text { de recursos; Interpessoais: capacidade de trabalhar com outros; Informação: } \\
\text { capacidade de receber e dar informação utilizando os modernos meios de } \\
\text { comunicação; Sistemas: capacidade de entender as relações complexas; } \\
\text { Tecnologia: capacidade de trabalhar com uma variedade de tecnologias; } \\
\text { - Competências fundamentais: Estas podem ser classificadas segundo três } \\
\text { elementos: Habilidades básicas: capacidade de ler, escrever, realizar cálculos } \\
\text { aritméticos e matemáticos, de ouvir e de expressar-se; Habilidades racionais: } \\
\text { estas se referem a capacidade de pensar criativamente, tomar decisões, resolver } \\
\text { problemas, visualizar, saber aprender e raciocinar; Qualidades pessoais: } \\
\text { capacidade de demonstrar responsabilidade, auto-estima, sociabilidade, } \\
\text { autocontrole, integridade e honradez. }\end{array}$ \\
\hline México & $\begin{array}{l}\text { - Competências básicas: referem-se aos comportamentos elementares que os } \\
\text { trabalhadores deverão demonstrar e estão associadas a conhecimentos de } \\
\text { natureza formativa, como a capacidade de leitura, de expressão e comunicação } \\
\text { verbal e escrita; } \\
\text { - Competências genéricas: descrevem comportamentos associados com } \\
\text { desempenhos comuns a diversas ocupações e áreas de atividade produtiva, como } \\
\text { a capacidade de trabalhar em equipe, de planejar, programar, negociar e treinar, } \\
\text { que são comuns a uma grande quantidade de ocupações; } \\
\text { - Competências específicas: são as que identificam comportamentos associados } \\
\text { a conhecimentos de natureza técnica, vinculadas a uma certa linguagem e a uma } \\
\text { função produtiva determinada. }\end{array}$ \\
\hline $\begin{array}{l}\text { Reino } \\
\text { Unido }\end{array}$ & $\begin{array}{l}\text { - Competências específicas de setor: Referem-se aos conhecimentos, destrezas } \\
\text { e atitudes requeridas para o desempenho numa atividade profissional específica; }\end{array}$ \\
\hline
\end{tabular}




\begin{tabular}{|l|l|}
\hline País & Definições \\
\hline \multirow{3}{*}{ - Competências genéricas: As competências genéricas são comuns ao conjunto } \\
de setores, mas correspondentes a uma mesma ocupação; \\
$\begin{array}{l}\text { - Competências ou habilidades essenciais: Estas se dividem em competências } \\
\text { de solução de problemas, comunicação e atitudes pessoais e competências } \\
\text { aritméticas, uso de informação tecnológica e uso da linguagem moderna. }\end{array}$ \\
\hline Quadro 9 - Tipologias de competência nos países. Elaborado pelo autor a partir da análise de OIT (2002).
\end{tabular}

De forma similar, o projeto DeSeCo (The Definition and Selection of Key Competencies Definição e Seleção de Competências-Chave), promovido pela OECD desde o final de 1997, realizou pesquisas em 12 países. O projeto contou com a cooperação de inúmeros especialistas de diversas áreas do conhecimento para refletir e definir as principais competências que deveriam ser promovidas nos sistemas educacionais.

Para ser bem sucedido na economia do conhecimento é preciso o domínio de um conjunto de conhecimentos e competências. As três categorias de competências-chave são (OECD 2002):

- Agir de forma autônoma: Construir e praticar um senso de si mesmo, tomar escolhas e agir em contextos de cenários mais amplos, ser orientado em direção ao futuro, ser consciente do ambiente, compreender como cada coisa se encaixa, praticar seus próprios direitos e responsabilidades, determinar e executar um plano de vida e planejar e cumprir projetos pessoais;

- Usar ferramentas interativamente: Usar ferramentas como instrumentos para um diálogo ativo; ter consciência de atualização e responder para a possibilidade de uma nova ferramenta; e ser capaz de usar a linguagem, textos, símbolos, informação e conhecimento, e tecnologia de maneira interativa para cumprir metas;

- Interagir em grupos heterogêneos: ser capaz de interagir eficazmente com outras pessoas, incluindo aquelas de diferentes formações; reconhecer a inserção social dos indivíduos; criar capital social; e ser capaz de se relacionar bem com outros, cooperando, gerenciando e resolvendo conflitos.

Domingues (2003) divide as competências em teóricas, práticas, relacionais e estratégicas. Já Fonseca (2003), as agrupa em gerenciais, técnicas e sociais. Marcket citado por Mitchell (2004) cria apenas dois agrupamentos, técnicas e comunicativas. As definições destes grupos não são diferentes dos autores já citados, por isso aqui são apenas lembrados. 
No artigo de Le Deist e Winterton (2005), encontramos alguns tipos de competências usadas em alguns países na revisão da literatura, antes deles proporem sua própria tipologia.

$\mathrm{Na}$ Alemanha, temos outra perspectiva da encontrada em OIT (2002). Esta é embasada em três competências principais: domínio ou assunto, pessoal e social. Esta abordagem de "competência de ação" foi adotada pelo sistema de educação e alterou o foco do assunto (inputs) para competência (outcomes).

A primeira competência, que consiste em domínio ou assunto (Fachkompetenz), significa a vontade e capacidade, com base em temas específicos de habilidades e conhecimentos, para cumprir tarefas e resolver problemas e julgar os resultados de uma maneira orientada a objetivos, apropriada, metodológica e independente.

A competência pessoal (Personalkompetenz) descreve a vontade e capacidade, como uma personalidade individual, de compreender, analisar e julgar as oportunidades de desenvolvimento, requerimentos e limitações na família, no trabalho e na vida pública para desenvolver as próprias habilidades assim como decidir sobre os planos e desenvolvê-los.

Por fim, a competência social (Soziaekompetenz) descreve a vontade e capacidade de experienciar e modelar relacionamentos para identificar e compreender benefícios e tensões, bem como interagir com outros de uma maneira racional e consciente, incluindo o desenvolvimento de responsabilidade social e solidariedade.

Conforme já citado, na França, temos também uma abordagem geralmente mais compreensiva ao correlato americano KSA (Knowledge, Conhecimento; Skills, Habilidades; Attitudes, Atitude/Comportamento). Assim, estas três grandes competências seriam: competénces théoriques (savoir, equivalente ao knowledge), competénce pratiques (savoirfaire, equivalente ao skills) e competénce sociales et comportamentales (savoir-être, equivalente ao Attitudes).

A Áustria adota uma abordagem similar a germânica. Assim, seus três agrupamentos de competências são: cognitivo, social e pessoal. A competência cognitiva (Sachkompetenz) é definida como "conhecimentos, habilidades e capacidades que podem ser usadas em uma 
ocupação específica, assim como transversalmente, e habilidades e capacidades para dominar tarefas e desenvolver estratégias apropriadas de solução de problemas" (Le DEIST \& WINTERTON, 2005, p.28). A competência social (Sozialkompetenz), por sua vez, está atrelada ao relacionamento e é definida como "a capacidade e vontade para cooperar, interagir com os outros responsavelmente e pertencer a um grupo de maneira relacional" (ibid., p.28). E, a competência pessoal (Selbstcompetenz) são as qualificações-chave para lidar com si próprio e é definido como "capacidade e vontade para desenvolver a si próprio, bem como para desenvolver habilidades, motivação e atitudes para o trabalho e para o mundo em geral" (ibid., p.28).

A tipologia elaborada por Le Deist e Winterton (ibid.) compreende competências requeridas por uma ocupação - tanto competências conceituais (cognitiva, conhecimento e compreensão), quanto competências operacionais (funcionais, psicomotoras e habilidades aplicadas) -, e também, compreende competências associadas com a eficácia individual tanto competências conceituais (metacompetência e aprender a aprender), quanto competências operacionais (competência social, comportamento e atitudes). A relação entre elas é apresentada na primeira parte da figura abaixo.

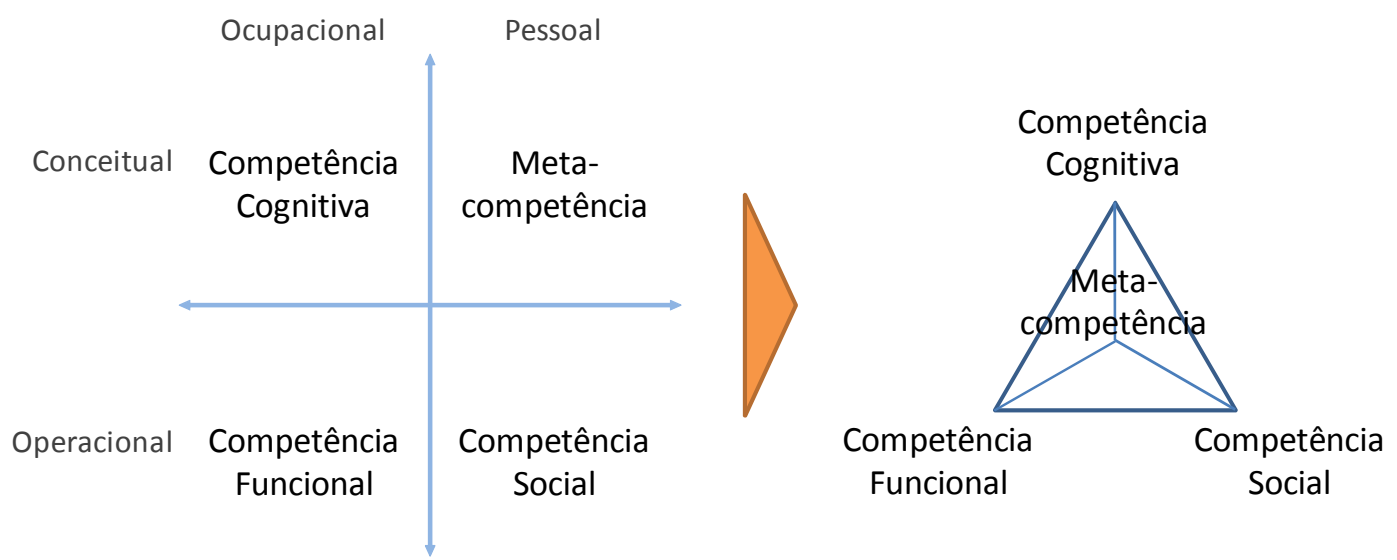

Figura 9 - Representação da tipologia de Le Deist \& Winterton (ibid.). (Análise do autor das figuras das p.39-40).

Conforme a opinião dos próprios autores, a segunda representação, no formato de um tetraedro, faz mais sentido, pois a metacompetência está associada ao desenvolvimento das demais competências. Em outras palavras, a metacompetência está no topo do tetraedro facilitando a aquisição de competências de resultados na base. Além disso, "reflete a unidade de competência e a dificuldade de separar na prática o que é cognitivo, funcional e social" (ibid., p.40), bem como possibilita a combinação de competências em suas faces. 
O modelo ainda é harmônico com a abordagem americana e francesa, pois a competência cognitiva captura o savoir e knowledge; a competência funcional captura o savoir-faire e skills; e, a competência social captura o savoir-être e o attitude.

Por fim, é válido mencionar que outros tantos autores desenvolveram tipologias de competências, entretanto os agrupamentos não foram baseados em características próximas de competências, por isso preferiu-se não trabalhar com eles. $\mathrm{O}$ quadro abaixo elenca alguns deles:

\begin{tabular}{|l|l|}
\hline Autor & Tipos de Competências \\
\hline Sparrow e Bognanno (1994) & $\begin{array}{l}\text { Emergentes, Declinantes, Estáveis ou Essenciais e } \\
\text { Transitórias }\end{array}$ \\
\hline $\begin{array}{l}\text { Doz (1994) citado por } \\
\text { Gianfaldoni, 1999) }\end{array}$ & Individuais, Organizacionais e Chave \\
\hline Gramigna (2002) Quadro 10 - Tipologias não consideradas (elaborado pelo autor). \\
\hline
\end{tabular}

Sparrow e Bognanno (1994) agrupa competências segundo o seu estado. Se são novas e estão em desenvolvimento, são emergentes; se estão caindo em desuso, são declinantes; se são permanentes, são estáveis; ou se são passageiras, são transitórias.

Doz (1994 apud GIANFALDONI, 1999) define três níveis de competências. As individuais estão relacionadas às habilidades observáveis dentro de grupos de trabalho. As competências organizacionais são "processos subjacentes que permitem combinar habilidades, sistemas, ativos e valores que buscam uma vantagem competitiva e fornecem funcionalidades aos clientes" (ibid., p.6). Já as competências-chave da organização atendem quatro dilemas da competitividade: 1) Qual o equilíbrio entre conhecimento implícito e codificação? Entre competências específicas e competências incorporadas (metacompetência)? Entre competências de base e novas oportunidades de inovação? Entre aprofundar as competências existentes e revitalizá-las.

Por fim, Gramigna (2002) classifica competências com a intenção de priorizá-las sob o aspecto estratégico. Assim as duas primeiras competências deveriam receber maior atenção, pois auxiliam na competitividade da organização, enquanto que as duas últimas, pouco valor 
agregam e, inclusive poderiam ser transferidas para organizações cuja esta seja a sua especialidade.

\subsection{Análise das Tipologias de Competências}

Um leque muito grande de tipologias de competências foi encontrado, logo é preciso diminuir a quantidade para se escolher com mais critérios a tipologia que esteja de encontro aos objetivos deste trabalho.

$\mathrm{Na}$ primeira etapa, excluímos as mais complexas, detalhadas e as divididas por nível que poderiam prejudicar ou complicar a coleta e análise dos dados. É válido ressaltar que as tipologias descartadas trazem uma contribuição para o campo de conhecimento, entretanto aqui não são adequadas para as finalidades do estudo. Assim, desconsideraremos as tipologias de Boyatzis (1982), Schroder (1989 apud Cockerill, 1994), Spencer e Spencer (1993), Nordhaug (1998), MCI (apud REYNOLDS, 1999).

Entre as tipologias restantes, notamos forte presença da competência social - 17 em 23 -, ora adotando outros sinônimos com os termos: interpessoais, networking, comunicação e interpessoal, trabalhar em equipe, interagir em grupos heterogêneos e relacionais.

Com presença similar, temos a competência funcional - 16 em 23 -, também considerando seu significado com outros termos, como: técnicas, técnico-profissionais, práticas e usar ferramentas interativamente.

A terceira mais presente é a competência cognitiva - 10 em 23. Esta também é referenciada com os termos: conceituais, open thinking, intelectuais, teóricas e domínio/assunto.

Notamos que a tipologia de Yukl (1989) mantém-se presente ao longo das demais tipologias e ao longo dos anos. E, mesmo alguns outros autores reconhecendo outras competências (exemplo: negócio, processos, entre outros), acreditamos que podemos interpretá-las como combinações destas três principais competências. 
Outro ponto que precisa ficar claro, é que conforme já citado por Parry (1996) neste trabalho, preferimos não trabalhar com personalidade, valores e estilos (soft), pois embora sabe-se que estas podem contribuir para o sucesso empresarial, duvida-se que possam ser passíveis de mudanças (ibid.).

Outro fato, oriundo da revisão sobre aprendizagem é a importância da capacidade do indivíduo em aprender a aprender. Logo, faz-se importante considerarmos a metacompetência e, conseqüentemente, a tipologia de Le Deist e Winterton (2005) por completo para os fins deste estudo.

\subsection{Pressupostos Teóricos}

Nesta seção abordaremos como a teoria vista na revisão bibliográfica foi aproveitada em prol dos objetivos deste trabalho e da elaboração do instrumento de pesquisa.

Por conta das metáforas de Sfard (1998), consideramos a aprendizagem neste trabalho como sendo um processo e não um produto.

Aprendizagem é exposto por diversos pesquisadores como sendo um termo de difícil conceitualização (SALVADOR, 1994; BECKETT; HAGER, 2002; FULLER et al, 2003; ABBAD; BORGES-ANDRADE, 2004; ABBAD; MOURÃO, 2006; COELHO Jr.; BORGES-ANDRADE, 2008). Entretanto a sua definição é essencial para este trabalho.

Logo, partindo da análise conceitual de Ryle (1970), promovida por Coelho Jr. e BorgesAndrade (2008), que investigou seu uso na linguagem cotidiana e por meio da análise do termo propriamente dito; e, analisando diversas definições (HOULE, 1980; HERGENHAHN, 1988; MERRIAM; CAFFARELLA, 1991; MEZIROW, 1991; KOLB, 1984; JARVIS, 1987; CELL, 1984; ISCED 1997), pode-se chegar a uma que extrapola o uso comum do termo de adquirir (obter) e reter (fixar) conhecimentos e habilidades por meios tradicionais. Portanto, neste trabalho consideramos aprendizagem como sendo um processo potencial e dinâmico que envolve mudança, reorganização e transformação de experiências, informações e stimuli em conhecimentos, habilidades, atitudes, valores e interpretações para nortear a ação futura. 
Além disso, foi identificado que a aprendizagem pode ocorrer em diferentes níveis de profundidade, desde corrigir um erro (CELL, 1984; ARGYRIS, 1999) ou decorar/lembrar de algo (BLOOM, 1956), até repensar seu próprio processo de aprendizagem (CELL, 1984; ARGYRIS, 1999), ou mesmo, criar algo novo (CELL, 1984; ANDERSON \& KRATHWOHL, 2001).

Outro conceito relevante para este trabalho é o evento de aprendizagem. Não seguimos as definições propostas por Tough (1979), Heap (1996) ou Eurostat (2006), pois a intencionalidade e a organização são características não garantidas para todos os eventos de aprendizagem, além de faltar a característica de aprendizagem potencial. Preferimos então adotar a definição de que evento de aprendizagem é uma oportunidade de aprendizagem que parte da necessidade, motivação ou consciência do indivíduo.

Na seqüência, fizemos uma análise crítica do Classification Learning Activities (EUROSTAT, 2006), do Taxonomy of Informal Professsional Learning Methods (CHEETHAM; CHIVERS, 2001) e da matriz de Conner (2006) e baseando-se em conceitos de Mocher e Spear (1982), Cell (1984), Marsick e Watkins (1990), Darrah (1996), Eraut (2000), Billet (2001), Colley et al (2003), Fuller et al (2004) e Fuller e Unwin, (2004), foi possível elaborar um modelo de classificação de eventos de aprendizagem, cujo primeiro continuum está ligado à organização da aprendizagem, e o segundo à intencionalidade da aprendizagem.

Além da própria estrutura de classificação, emergiram quatro grupos de eventos de aprendizagem: Aprendizagem Conceitual, Aprendizagem Provocada, Aprendizagem Experiencial e Aprendizagem Experiencial Induzida.

No bloco pertinente a competência, apresentamos que mais do que inputs - estoques de qualificações, ou "clusters de conhecimentos, habilidades e atitudes" (PARRY, 1996), competência está relacionada à mobilização deste estoque para gerar "entrega" (DUTRA, 2002) e pode ser definida como:

"Competência é um saber agir responsável e reconhecido, que implica mobilizar, integrar, transferir conhecimentos, recursos, habilidades, que agreguem valor econômico à organização e valor social ao indivíduo" (FLEURY; FLEURY, 2001). 
$\mathrm{Na}$ seqüência, após a análise de vinte e oito tipologias de competências encontradas em dezenove referências bibliográficas (BOYATZIS, 1982; YUKL, 1989 apud NORDHAUG, 1998; SCHRODER,1989 apud COCKERILL, 1994; SPENCER; SPENDER,1993; SPARROW; BOGNANNO,1994; CHEETHAM; CHIVERS, 1996; 1998; PARRY, 1996; ASTD apud PARRY, 1996; NORDHAUG, 1998; ZARIFIAN, 1999; MCI (apud REYNOLDS, 1999); FLEURY \& FLEURY, 2001; RABAGLIO, 2001; OIT, 2002; OECD, 2002; DOMINGUES, 2003; FONSECA, 2003; MARCKET apud MITCHELL, 2004; Le DEIST; WINTERTON, 2005) a tipologia de Le Deist \& Winterton (2005) foi escolhida para representar os tipos de competências que trabalhamos, pois além de estar presente de certa forma em diversas outras tipologias, esta foi considerada a melhor para as finalidades deste estudo. As competências são: Cognitiva, Funcional, Social e Metacompetência. 


\section{METODOLOGIA}

\subsection{Enquadramento da Pesquisa}

Para fins de classificação (GIL, 2002), esta pesquisa se enquadra como sendo uma pesquisa descritiva na sua grande maioria, porém também com caráter exploratório, pois visa levantar as características de uma determinada população e a associação entre algumas variáveis, especificamente para uma amostra. Logo, não se pode inferir conclusões para toda a população.

Além desta classificação, em relação aos tipos de hipótese teremos testes referentes à relação de dependência entre duas ou mais variáveis (GIL, 2002).

\subsection{A FEA-USP: Motivos da Escolha}

A população de respondentes explorada foi composta por ex-alunos de graduação e pós da Faculdade de Economia, Administração e Contabilidade da Universidade de São Paulo. Tal escolha foi determinada pelos seguintes fatores:

- Representa uma população com formação de mesmo nível;

- A instituição é uma das primeiras instituições brasileiras no ensino de Economia, Administração e Contabilidade no Brasil, o que possibilita a comparação de gerações;

- Estudo prévio (CASSIMIRO, 2005) com a intenção de estudar os interesses de relacionamento entre ex-alunos e instituição de ensino, o que facilita a interação e análise;

- Conveniência no acesso aos dados de contato dos egressos para enviar o instrumento de pesquisa por e-mail;

- Apoio formal e incentivo da instituição de ensino e do Programa de Relacionamento com Ex-alunos, FEA+ (lê-se: FEA mais). 


\subsection{A FEA-USP}

A Faculdade de Economia, Administração e Contabilidade é uma unidade da Universidade de São Paulo fundada em 26 de janeiro de 1946. É uma instituição que desponta entre as melhores do Brasil em sua área, tanto na graduação quanto na pós-graduação, segundo as avaliações da CAPES.

A Universidade de São Paulo está entre as 100 melhores universidades do mundo segundo a Council of Taiwan, ocupa a posição 124 entre as 500 melhores universidades, segundo o Institute of Higher Education Shanghai Jiao Tong University, e 196 entre as 200 universidades de maior relevância mundial, segundo o The Times.

A USP representa mais de $25 \%$ da pesquisa científica nacional. Por muito tempo também ostentou o título da maior universidade brasileira. O anuário estatístico da USP de 2007 apresentou os seguintes dados: 5.434 professores, 51.873 alunos de graduação, 31.826 alunos de pós-graduação, 15.221 funcionários e 40 unidades de ensino.

Tais créditos levam com que a instituição atraía candidatos de todos os estados brasileiros e formasse um bom corpo discente, já que seu processo seletivo é bastante concorrido.

$\mathrm{Na}$ graduação, a FEA-USP sempre apresentou boas avaliações em seus cursos, tanto na avaliação do Ministério da Educação (Conhecida como "Provão"), quanto nos demais rankings privados (Guia do Estudante etc.). Na pós-graduação a qualidade é comprovada pela CAPES. Os três programas de pós-graduação apresentam as melhores avaliações entre as instituições avaliadas.

Em relação às demais instituições da área, a FEA-USP possui grande produção científica com 1.005 artigos científicos publicados no ano de 2007 (USP, 2007). É formadora de corpo docente para outras IES, além de egressos que sobressaem nos cenários político, econômico e empresarial. Além disso, é uma instituição expressiva em internacionalização no Brasil; estabelece convênios com 68 instituições de ensino internacionais e uma das pioneiras em duplo diploma com universidades internacionais e co-tutela de teses. 
Em 2007, a FEA-USP possuía 3.042 alunos de graduação, 725 de pós-graduação, 181 professores e 15.459 ex-alunos.

\subsubsection{O Programa FEA+: Relacionamento com Ex-alunos}

O surgimento das áreas de desenvolvimento institucional e de alumni relations surgiram para institucionalizar e impulsionar as iniciativas de captação de recursos das universidades americanas que enfrentavam escassez de recursos (CASSIMIRO, 2005). A primeira iniciativa de que se tem registro foi o Yale Alumni Fund, estabelecido em 1890, que foi o primeiro fundo formal deste tipo (GEARHART, 1989).

Até hoje nos Estados Unidos o foco principal de atuação da área de relacionamento com exalunos é a captação de recursos, este viés também se reflete nas pesquisas conduzidas nesta área (GEARHART, 1989; HANSON, 2000; ARNOLD, 2003; DAVIDSON-SHIVERS et al, 2004; PUMERANTZ, 2004; CASSIMIRO, 2005).

Entretanto, o programa de relacionamento com ex-alunos da FEA-USP (FEA+) tem uma visão mais ampla e abrange também o benefício dos egressos. Conforme citação da diretora da FEA na época, Profa. Maria Tereza Leme Fleury, no jornal de comunicação interna Gente da FEA (2005): “precisamos [a FEA] abrir um canal para que ele [ex-aluno] possa contribuir com a faculdade, ao mesmo tempo em que esta contribui com ele, isto é, criar uma via de mão-dupla”.

Os ex-alunos da FEA também têm à disposição a Associação dos Diplomados da FEA (ADIFEA) criada em 1954, entretanto a organização é uma entidade independente. Posto isso, pouco da relação com a associação alcança a própria instituição e são frequentes os casos de conflitos por conta da sobreposição de papéis, público-alvo e interesses (ARNOLD, 2003).

Inúmeras atividades já foram empreendidas pelo FEA+ que vão desde ações presenciais (encontros de turmas, networking nights, palestras etc.) a ações virtuais (Portal, Comunidade e Newsletter). Este é o ponto que mais nos importa neste trabalho, por conta da atualização frequente do banco de dados dos contatos torna-se viável estruturar uma pesquisa e obter uma taxa de retorno positiva nos questionários. 


\subsection{População e Amostragem}

A população de ex-alunos da graduação da FEA é de 15.459. Nos primeiros 10 anos a instituição formava grupos pequenos de dezenas de formandos Hoje em dia, forma mais de 500 alunos por ano nos quatro cursos.

A proporção de alunos é distribuída da seguinte maneira: $32 \%$ de alunos de graduação em administração, $9 \%$ de pós-graduação em administração; $28 \%$ de graduação em economia, 2\% de pós-graduação em economia; $23 \%$ de graduação em contabilidade, $3 \%$ de pós-graduação em contabilidade; e, $3 \%$ de graduação em atuária.

A amostragem foi não-probabilística e por conveniência, visto que pelo método probabilístico seria quase inviável realizar esta pesquisa. Consideramos os ex-alunos cadastrados no portal do FEA+, mas não descartamos a participação de outros respondentes que receberam convites de outros ex-alunos.

\subsection{Instrumento de Pesquisa}

Após a elaboração da primeira versão do questionário, realizou-se o pré-teste, que envolveu 13 respondentes. Este grupo de respondentes foi composto por ex-alunos da FEA e também por professores, doutores e mestres nas áreas de marketing e recursos humanos.

Inúmeras contribuições foram feitas e as mais pertinentes e relevantes foram consideradas. Estas alterações vão ao encontro com os conceitos de elaboração de questionários e formulários promovidos por Malhotra (2002). Em outras palavras, enunciados e assertivas foram reescritos, escalas e ordem das questões foram alteradas, e questões foram eliminadas. As mudanças promoveram a melhor compreensão das questões, a facilidade de resposta e a velocidade com que os indivíduos concluíam a pesquisa. 
A duração de 7 minutos citados no convite foi superestimada, inclusive alguns respondentes disseram que o questionário estava bem simples e nem lhes tomou 5 minutos, segundo citações constatadas no campo observação ou em emails enviado ao pesquisador.

Em relação à estrutura, no primeiro bloco temos as questões que atendem aos objetivos desta pesquisa diretamente. As questões de 2 a 5 são as principais, nelas constam a avaliação de cada grupo de eventos de aprendizagem para o desenvolvimento de cada competência.

Os quadros abaixo apresentam as expressões utilizadas no questionário para traduzir os termos teóricos vistos na revisão bibliográfica.

\begin{tabular}{|l|l|}
\hline Termo teórico & Expressão utilizada no questionário \\
\hline Competência Social & Capacidade de mobilizar e interagir com as pessoas \\
\hline Competência Funcional & Capacidade de cumprir tarefas e executar processos \\
\hline Competência Cognitiva & Capacidade de analisar e resolver problemas \\
\hline Metacompetência & Capacidade de aprender a aprender \\
\hline
\end{tabular}

\begin{tabular}{|l|l|}
\hline Termo teórico & Expressão utilizada no questionário \\
\hline Aprendizagem Conceitual & As aulas expositivas e palestras das quais participei \\
\hline Aprendizagem Provocada & A observação e o feedback de outros profissionais \\
\hline Aprendizagem Experiencial & A experiência no trabalho e em outras atividade \\
\hline $\begin{array}{l}\text { Aprendizagem Experiencial } \\
\text { induzida }\end{array}$ & A participação em simuladores e estudo de casos \\
\hline
\end{tabular}

Quadro 12 - Expressões utilizadas no questionário para grupos de eventos de aprendizagem.

Buscou-se nos itens do questionário não a tradução total do conceito, mas a apresentação simplificada para que o respondente pudesse facilmente responder.

Cada uma destas questões avaliava uma competência e o respondente deveria avaliar as quatro assertivas relacionadas aos grupos de eventos de aprendizagem. A escala de respostas continha 10 pontos mais uma opção para aqueles que optassem por não responder a concordância da assertiva.

Ainda neste primeiro bloco de questões, perguntou-se quais dos três tipos de capacidades eram os mais significativos para o desempenho do trabalho atual. Consideraram-se as 
competências social, funcional e cognitiva e desconsiderou-se a metacompetência, por esta ser algo não diretamente associado à promoção da "entrega". As mesmas adaptações dos termos apontadas no Quadro 11 - Expressões utilizadas no questionário para competências. também foram adotadas.

No segundo bloco, buscou-se analisar a frequência com que os respondentes praticavam os eventos de aprendizagem. Assim, como respostas havia quatro opções além da "não sei": nunca, pouco frequente, frequente e muito frequente.

Embora Malhotra (ibid.) aponte que esta escala adotada seja ambígua, pois tem "significados diferentes para cada pessoa" (ibid., p. 284), esta foi considerada por alguns motivos de caráter prático. A dificuldade do indivíduo em mensurar os eventos de aprendizagem em um determinado período, sobretudo os de cunho não intencional foi o principal fator que motivou o uso desta escala. O segundo fator foi que a percepção geral do indivíduo nesta escala de quatro opções já atende o nível de profundidade buscada nesta análise. Além disso, pelo fato de ser uma escala de número par, esta força a escolha do respondente e não deixa uma opção meio-termo ou "em cima do muro".

O quadro abaixo apresenta as expressões utilizadas no questionário e o evento de aprendizagem que faz referência no plano teórico. É válido mencionar que os eventos foram levantados a partir da Figura 8.

\begin{tabular}{|c|c|c|}
\hline & Evento de aprendizagem & Expressão utilizada no questionário \\
\hline \multirow{5}{*}{ 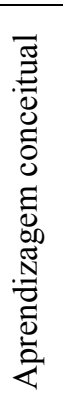 } & Aulas & Assisto aulas expositivas \\
\hline & eLearning & Faço cursos de eLearning \\
\hline & Palestra & Assisto palestras \\
\hline & Aula hands-on & Participo de aulas em que aprendo fazendo (hands-on) \\
\hline & Aula particular & Faço uso de aulas particulares \\
\hline
\end{tabular}




\begin{tabular}{|c|c|c|}
\hline & Evento de aprendizagem & Expressão utilizada no questionário \\
\hline \multirow{8}{*}{ 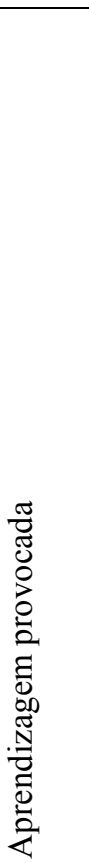 } & Feedback & Recebo feedback \\
\hline & Mentoring & Converso com um mentor ou tutor \\
\hline & $\begin{array}{l}\text { Mecanismos psicológico / } \\
\text { neurológicos }\end{array}$ & $\begin{array}{l}\text { Faço uso de mecanismos que facilitem a compreensão } \\
\text { de um problema (ex.: representação gráfica e } \\
\text { pensamento lateral) }\end{array}$ \\
\hline & Prática e repetição & $\begin{array}{l}\text { Repito uma tarefa ou ensaio algo com o intuito de } \\
\text { aprimorá-lo }\end{array}$ \\
\hline & Reflexão & Reflito sobre minhas próprias ações e comportamentos \\
\hline & Reflexão (ações de outro) & Reflito sobre ações e comportamentos dos outros \\
\hline & Observação e cópia & $\begin{array}{l}\text { Observo comportamentos de pessoas mais experientes } \\
\text { ou tento fazer algo como alguém }\end{array}$ \\
\hline & Leitura técnica & $\begin{array}{l}\text { Leio livros e revistas relacionados ao trabalho e } \\
\text { profissão }\end{array}$ \\
\hline \multirow{7}{*}{ 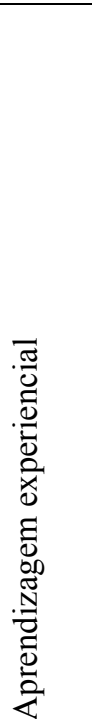 } & Articulação & Estruturo uma idéia no papel ou para uma apresentação \\
\hline & Ser mentor & Dou conselhos como mentor ou tutor de alguém \\
\hline & Mudança de perspectiva & $\begin{array}{l}\text { Busco mudar de perspectiva ou me colocar em outra } \\
\text { posição para compreender outro ponto de vista }\end{array}$ \\
\hline & Colaboração e ligação & Trabalho em times ou de forma colaborativa \\
\hline & $\begin{array}{l}\text { Transferência extra- } \\
\text { ocupacional }\end{array}$ & $\begin{array}{l}\text { Busco conectar aprendizados prévios ou de outras } \\
\text { atividades fora do trabalho }\end{array}$ \\
\hline & Forças atividades & $\begin{array}{l}\text { Participo de projetos desafiadores ou vivencio situações } \\
\text { difíceis }\end{array}$ \\
\hline & $\begin{array}{l}\text { Absorção inconsciente ou } \\
\text { osmose }\end{array}$ & $\begin{array}{l}\text { Aprendo por osmose trabalhando com pessoas mais } \\
\text { experientes }\end{array}$ \\
\hline \multirow{4}{*}{ 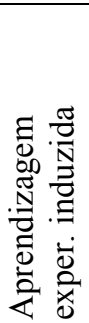 } & Simuladores & Participo de simuladores \\
\hline & Jogos de empresas & Participo de jogos de empresas \\
\hline & Estudos de caso & Leio estudos de caso e tento resolvê-los \\
\hline & Treinamento on-the-job & $\begin{array}{l}\text { Participo de treinamentos no próprio ambiente de } \\
\text { trabalho }\end{array}$ \\
\hline
\end{tabular}

Por fim, no terceiro bloco buscou-se levantar questões relacionadas ao perfil do usuário com o objetivo de aprofundar a análise da pesquisa. Assim, as questões obrigatórias foram: ano de nascimento, grau máximo obtido, curso de graduação na FEA, ano de conclusão, cidade, estado e país aonde vive, Status profissional, nível hierárquico. E as questões não obrigatórias 
foram: nome, email, ocupação funcional, cargo, nome da organização, porte, setor de atividade da organização, tipo de organização, tempo na organização e dúvidas/comentários/sugestões.

\subsection{Levantamento}

A pesquisa foi realizada pela internet utilizando-se ferramenta específica para o determinado fim. Avaliaram-se alguns provedores deste tipo de serviço e optou-se pela adoção do Surveymonkey.com, pois além de possuir todas as características necessárias para a realização da pesquisa sem alterações nas questões, apresentou o custo mais viável.

O acesso foi o critério-chave de escolha na adoção deste canal, visto que os ex-alunos estão espalhados por todo o Brasil e pelo mundo afora. Também, a população é basicamente composta por "White-collar worker", o que minimiza a hipótese de falta de acesso à internet.

É válido lembrar que em algumas organizações os sistemas de proteção firewall e políticas corporativas podem restringir o acesso de seus funcionários a vários sites da internet. Como plano para contornar este problema também foi disponibilizado o questionário em formato MS Word para as pessoas que manifestarem interesse. Apenas um único respondente manifestou interesse nesta opção.

O convite à pesquisa (anexo 1) foi enviado no dia 14 de outubro para todos os ex-alunos cadastrados no programa FEA+. A pesquisa ficou aberta até o dia 23 de outubro.

\subsection{Tratamento dos Dados}

Ao longo deste período, 244 pessoas responderam o questionário. Doze respondentes foram eliminados, por não terem concluído os três blocos do questionário.

Depois, foram aplicados filtros para eliminar ex-alunos que não desempenham atividades profissionais. Sete ex-alunos foram desconsiderados por estarem em dedicação integral aos 
estudos em programas de doutorado e mestrado. Um foi eliminado por ser aposentado e outro por não responder seriamente a pesquisa. Seis ex-alunos estavam em transição em suas carreiras, entretanto se notou que todos responderam em relação à última atividade profissional desempenhada. Logo, o número final de respondentes válidos foi de 223 respondentes.

Ao longo do processo de tratamento, algumas alterações foram feitas nas variáveis para facilitar a análise e reduzir o número de grupos das variáveis categóricas independentes. Em relação às perguntas de localização, ou seja, cidade, estado e país aonde o respondente morava, derivou-se uma combinação das três variáveis. Assim, a nova variável apresentava os seguintes grupos de local de residência: grande São Paulo, interior de São Paulo e litoral, outro estado, outro país.

Para o grau máximo de formação, a questão possibilitava 7 respostas para os diferentes níveis de formação e se estavam concluídas ou em curso. Preferiu-se criar duas análises distintas. A primeira considerou apenas a trajetória seguida, independentemente da conclusão ou não do curso, assim os novos grupos foram: parou com a graduação, seguiu pós especialização, e seguiu pós acadêmica. A segunda considerou apenas o fato da pessoa estar cursando ou não alguma pós, logo os novos grupos foram: sim e não.

Os setores da economia também foram re-configurados com o objetivo de reduzir o número de grupos, porém ao mesmo tempo preservando a relevância de seu tamanho. Os 48 setores iniciais foram apresentados em 10 setores agregados.

1. Indústrias, que compreende: Automotivo (montadoras e autopeças); Brinquedos; Confecções, têxteis e moda; Cosméticos; Couro e calçado; Eletroeletrônico e computadores; Higiene; Farmacêutico; Limpeza; e, Moveleiro;

2. Indústrias de base e construção, que compreende: Bens de capital; Construção; Material de construção; Mineração; Papel e celulose; Plástico e borrachas; Química e petroquímica; e, Siderurgia e metalurgia;

3. Comércio, que compreende: Atacadista; Varejista; e, Exterior;

4. Agronegócio, que compreende: Agricultura e pecuária; Alimentícia; e, Bebidas e fumo; 
5. Serviços, que compreende: Comunicações; Cultura; Entretenimento; Esporte; Hotéis, bares e restaurantes; Saúde (hospitais e afins); Telecomunicações; Tecnologia e informática; Transporte e logística; e, Turismo.

6. Educação;

7. Consultoria;

8. Instituições financeiras;

9. Governo;

10. Outros;

Embora Educação, Consultoria e Instituições financeiras sejam serviços, o tamanho individual deste grupo é relevante para serem considerados um grupo distinto.

Nível hierárquico foi outra variável a ter os grupos revistos. De 21 grupos iniciais, temos 6 agrupados.

1. Analista e Consultor, que compreende: Analista, Consultor, Auditor, Especialista, Técnico, Assistente, Assessor e Trainee;

2. Média Gerência, que compreende: Gerente, Chefe, Coordenador, e Supervisor;

3. Alta gestão de pequena/média empresa, que compreende: Conselheiro, Presidente, VicePresidente, Superintendente, Secretário, Sócio e Diretor.

4. Alta gestão de grande empresa: Conselheiro, Presidente, Vice-Presidente, Superintendente, Secretário, Sócio e Diretor

5. Professor;

6. Outro.

O primeiro grupo levou em consideração de agrupamento o fato destes serem contribuidores individuais. O segundo considerou a coordenação de recursos para o cumprimento de metas. Já para a Alta gestão, considerou-se a posição de planejamento e decisão. A diferença entre a alta gestão de pequena/média e de grande empresa foi obtida cruzando esta variável com os grupos da variável porte de empresa. Esta divisão foi proposta devido às diferenças entre a gestão de uma grande empresa e de uma pequena empresa.

A última modificação nas variáveis foi a consideração da questão tempo na organização como categórica em três grupos: Menos de 5 anos; Entre 5 anos e 20 anos; e, 20 anos ou mais. 
Além disso, os dados foram tratados no software Microsoft Excel 2007 para serem inseridos no software SPSS 16. Após a inserção, todas as variáveis foram corretamente classificadas e as categorias foram nomeadas.

\subsection{Ferramentas Estatísticas Adotadas}

Os métodos estatísticos podem ser agrupados em dois tipos. O primeiro tipo é quando os métodos exploram relações de dependência entre os conjuntos de variáveis, ou seja, se há uma relação de causa-efeito entre as variáveis independentes e as variáveis dependentes. $\mathrm{O}$ segundo tipo é quando o objetivo é compreender o porquê e o como as variáveis estão correlacionadas entre si (SHARMA, 1996).

Os critérios da escolha do método também levam em consideração a quantidade das variáveis dependentes e independentes e a natureza das variáveis, se são métricas ou não-métricas. $\mathrm{O}$ Quadro 14 - Métodos estatísticos de dependência e o Quadro 15 - Métodos estatísticos de interdependência apresentam um resumo geral.

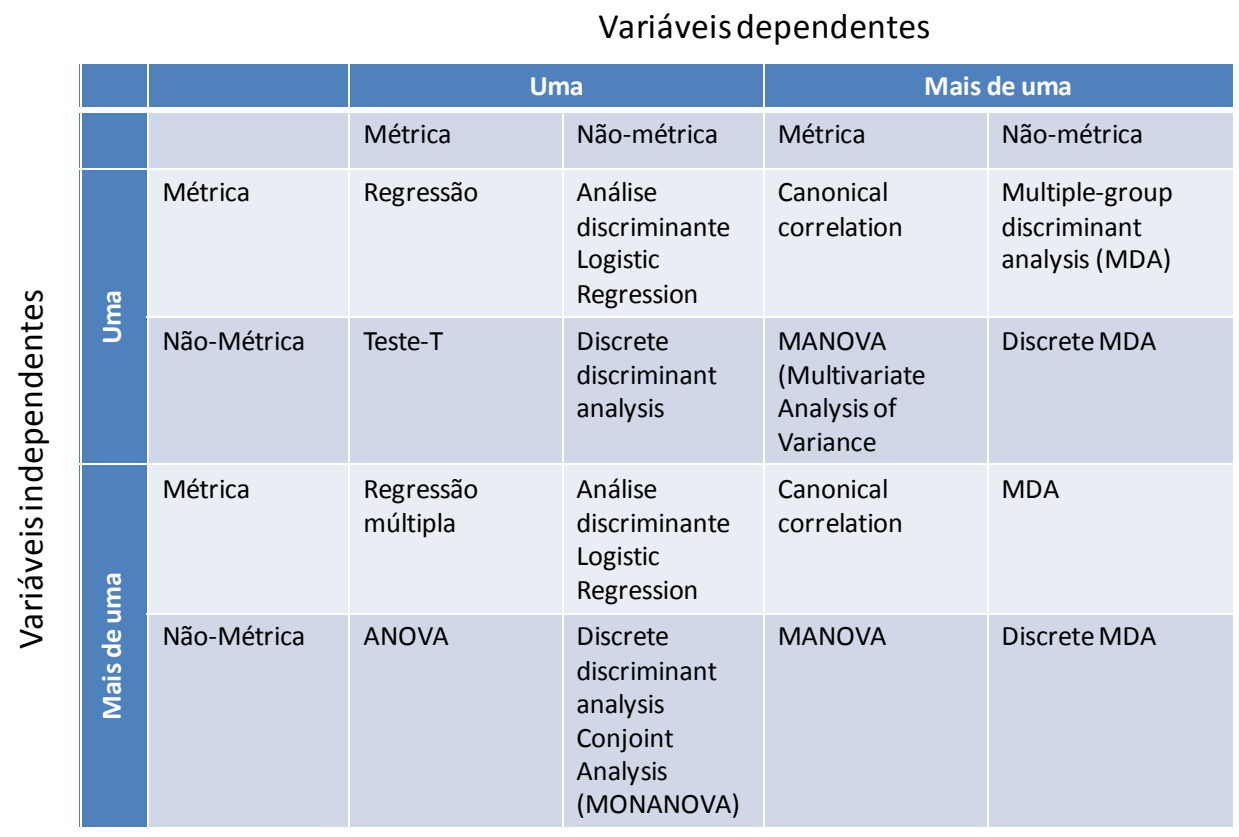

Quadro 14 - Métodos estatísticos de dependência (ibid., p.6) 
Tipo de dados

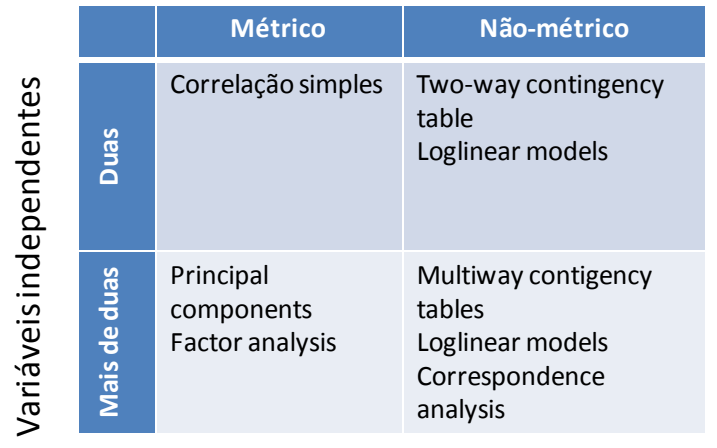

Quadro 15 - Métodos estatísticos de interdependência (ibid., p.11)

As hipóteses de pesquisa serão testadas por uma série de testes ANOVA. No aprofundamento da análise, realizaremos uma séria de testes ANACOR para os eventos de aprendizagem que apresentaram Qui-Quadrado significativo na relação com alguma variável de perfil. A bibliografia básica para a análise é proveniente de Sharma (1996), Pestana e Gageiro (2000), Malhotra (2002), Hair et al (2005) e Fávero et al (2009).

\subsubsection{Análise de Variância (ANOVA)}

Tanto no teste $\mathrm{t}$, quanto na ANOVA, a hipótese nula testada é a igualdade de médias da variável dependente ao longo dos grupos, sendo a primeira citada utilizada para comparar dois grupos e a segunda para mais de dois grupos (HAIR et al, 2005). Na ANOVA, a variável independente é não-métrica e a variável dependente é métrica.

Para considerar o teste paramétrico ANOVA, é preciso verificar que duas suposições sejam aceitas: 1) que a variável dependente tenha distribuição normal; e, 2) que as variâncias populacionais sejam homogêneas no caso da comparação de duas ou mais populações. (MAROCO, 2007 apud FÁVERO et al, 2009).

Existem vários testes para verificar a normalidade, Fávero et al (2009) recomendam os testes de Kolmogorov-Smirnov e de Shapiro-Wilks. Sendo o primeiro recomendado para grandes amostras e o segundo para pequenas amostras $(\mathrm{n}<30)$.

O teste de Kolmogorov-Smirnov (K-S) "é um teste de aderência que compara a distribuição de frequência acumulada de um conjunto de valores observados da amostra com uma 
distribuição esperada ou teórica" (FÁVERO et al, 2009, p.112). A hipótese nula H0 afirma que a amostra provém de uma distribuição normal, enquanto que a hipótese alternativa H1 afirma que a amostra não provém de uma distribuição normal.

Já para o teste a verificação da homogeneidade de variâncias entre populações os testes mais comuns são de Levene e de Bartlett. Aplicaremos neste estudo somente o teste de Levente por conta da conveniência de seu cálculo pelo software SPSS 16. O teste de Levene considera que a hipótese nula H0 afirma que as variâncias populacionais são homogêneas ou iguais entre as $\mathrm{k}$ amostras representativas, enquanto que a hipótese alternativa $\mathrm{H} 1$ afirma que pelo menos uma das variâncias populacionais é diferente das demais.

A ANOVA de um fator (one way ANOVA) é calculada pela divisão da variância do fator (SQF dividido por k-1 graus de liberdade) e a variância dos erros (SQE dividido por N-k graus de liberdade) (MAROCO, 2007 apud FÁVERO et al, 2009). O quadro abaixo resume os cálculos da ANOVA de um fator:

\begin{tabular}{|l|l|c|l|l|}
\hline $\begin{array}{l}\text { Fonte de } \\
\text { variação }\end{array}$ & Soma dos quadrados & $\begin{array}{l}\text { Graus de } \\
\text { liberdade }\end{array}$ & $\begin{array}{l}\text { Quadrados } \\
\text { médios }\end{array}$ & F \\
\hline Entre grupos & $S Q F=\sum_{i=1}^{k} n_{i}\left(\bar{Y}_{i}+\bar{Y}\right)^{2}$ & $k-1$ & $Q M F=\frac{S Q F}{k-1}$ & $F=\frac{Q M F}{Q M E}$ \\
\hline $\begin{array}{l}\text { Dentro do } \\
\text { grupo }\end{array}$ & $S Q E=\sum_{i=1}^{k} \sum_{j=1}^{n_{i}} n_{i}\left(Y_{i j}+\bar{Y}_{i}\right)^{2}$ & $N-k$ & $Q M E=\frac{S Q E}{n-k}$ & \\
\hline Total & $S Q T=\sum_{i=1}^{k} \sum_{j=1}^{n_{i}} n_{i}\left(Y_{i j}+\bar{Y}\right)^{2}$ & $N-1$ & & \\
& \multicolumn{3}{|c|}{ Quadro $16-$ Cálculos da ANOVA de um fator (fonte: ibid., 2009). }
\end{tabular}

Na sequência, a estatística $\mathrm{F}$ calculada é comparada com o $\mathrm{F}$ crítico, se for menor, não se rejeita a hipótese nula de que as médias populacionais são iguais; se for maior, rejeita-se a hipótese nula e adota-se a hipótese alternativa, ou seja, de que pelo menos uma das médias populacionais difere das demais.

Apesar do teste estatístico $\mathrm{F}$ avaliar a hipótese nula de médias iguais, ele não aborda a questão sobre quais médias são diferentes. Para avaliar as diferenças recorre-se aos testes de comparação planejadas ou Post Hoc (HAIR et al, 2005). Neste estudo consideraremos os 
testes de Tukey B e de Bonferroni. O primeiro agrupa em conjuntos ordenados as variáveis que apresentam médias estatisticamente iguais. O segundo faz comparações entre cada variável de diferenças de médias.

Por fim, é válido lembrar que quando um dos pressupostos (normalidade e/ou homogeneidade de variâncias) é rompido, os resultados do teste ANOVA só serão válidos se algum teste nãoparamétrico corroborar o mesmo resultado de rejeição ou aceitação da hipótese nula de que distribuição das $\mathrm{k}$ amostras são iguais (FÁVERO et al, 2009). Em nosso estudo consideraremos o teste de Kruskal-Wallis, por apresentar nível de mensuração ordinal para K amostras independentes, o qual também pode ser aplicado para variáveis quantitativas.

\subsubsection{Análise de Correspondência (ANACOR)}

A Análise de Correspondência Simples (ANACOR) é uma técnica de interdependência que estuda a relação entre duas variáveis qualitativas (nominais ou ordinais). Por meio de mapas perceptuais oferece a visualização de associações, fornecendo uma noção de proximidade, ou associações de frequências, das variáveis não métricas (FÁVERO et al, 2009).

Nestes mapas planos, as categorias com localização próxima têm relação mais forte do que as categorias distantes. Além disso, qualquer categoria pode ser analisada individualmente e caracterizada segundo a proximidade das projeções de todas as demais categorias sobre uma reta que a conecte até a origem dos eixos.

A ANACOR utiliza o teste Qui-Quadrado para padronizar os valores das frequências e formar a base para as associações.

O teste Qui-quadrado é um teste não-paramétrico aplicado a uma amostra em que a variável nominal assume duas ou mais categorias e compara as frequências observadas com as esperadas em cada uma. A hipótese nula H0 afirma não haver discrepâncias entre as frequências observadas e esperadas, enquanto que a hipótese alternativa H1 afirma haver discrepâncias. 
A partir de uma tabela de contingência, calculam-se as diferenças entre as frequências esperadas e o valor do Qui-quadrado para cada célula. Logo, padronizadas as medidas da associação, a ANACOR gera uma medida de distância e cria projeções ortogonais para alocar as categorias, de forma a representar o grau de associação dado pelas distâncias Qui-quadrado em um espaço dimensional (ibid.).

Massa é uma medida que indica a influência de um objeto com base em sua frequência marginal, em outras palavras representa a parcela de cada categoria que está presente no estudo. As categorias com maiores massas tendem a atrair o centróide para si.

Para existir um mapa percentual, o menor número de categorias entre as variáveis deve ser de 3 , caso contrário não será possível elaborar a representação. No mapa, a primeira dimensão é a que mais explica a variação existente nos dados.

Os valores próprios (eigenvalue) são coeficientes de correlação de Pearson entre os scores das duas variáveis (em linha e em coluna). O quadrado de cada valor próprio designa a inércia das dimensões, que mede a importância de cada dimensão. O quociente entre a inércia de cada dimensão e a inércia total dá a proporção de variância explicada pela dimensão.

As categorias mais explicativas das dimensões são as que apresentam maior inércia por dimensão e que simultaneamente se situam mais afastadas da origem $(0,0)$ nos gráficos (PESTANA; GAGEIRO, 2000).

A distribuição da inércia entre os scores pode ser feita pelos seguintes métodos de normalização (ibid.), os quais geram mapas diferentes:

- Em linha ou row principal: maximiza as distâncias entre as categorias dessa variável para saber como as variáveis se modificam linha;

- Em coluna ou column principal: maximiza as distâncias entre as categorias dessa variável para saber como as variáveis se modificam em coluna;

- Symmetrical: para conhecer as diferenças ou semelhança entre as duas variáveis;

- Principals: para conhecer as semelhanças ou diferenças entre as categorias de cada variável por si só. 


\section{ANÁLISE E RESULTADOS}

\subsection{Análise das Frequências}

Nesta parte do trabalho, apresentaremos as frequências obtidas para que tenhamos um panorama geral dos respondentes antes de iniciar o teste das hipóteses.

Em relação ao ano de nascimento, o gráfico abaixo apresenta a distribuição dos respondentes. Como a questão era de resposta obrigatória, não houve respostas em branco.

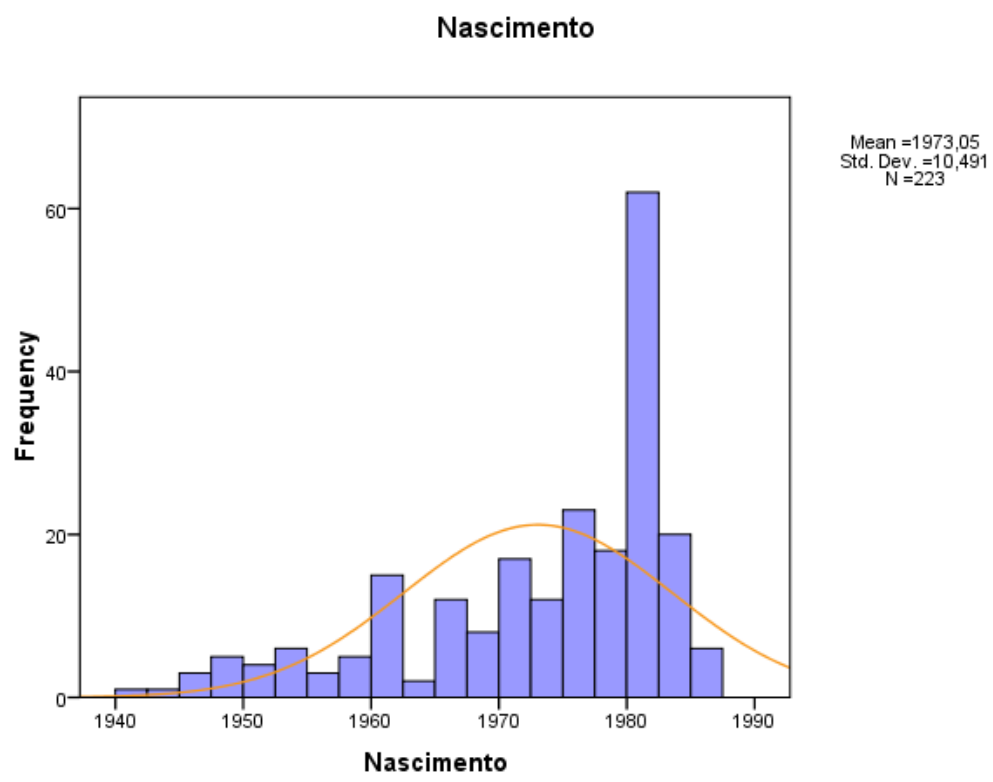

Figura 10 - Ano de nascimento.

A amostra apresenta uma faixa bem ampla de idade dos respondentes, respaldada pelo desvio padrão de 10,491. Embora exista uma concentração em relação aos respondentes nascidos próximo ao ano de 1980, o que justifica a moda de 1982, a média é de 1973 e a mediana de 1977. 


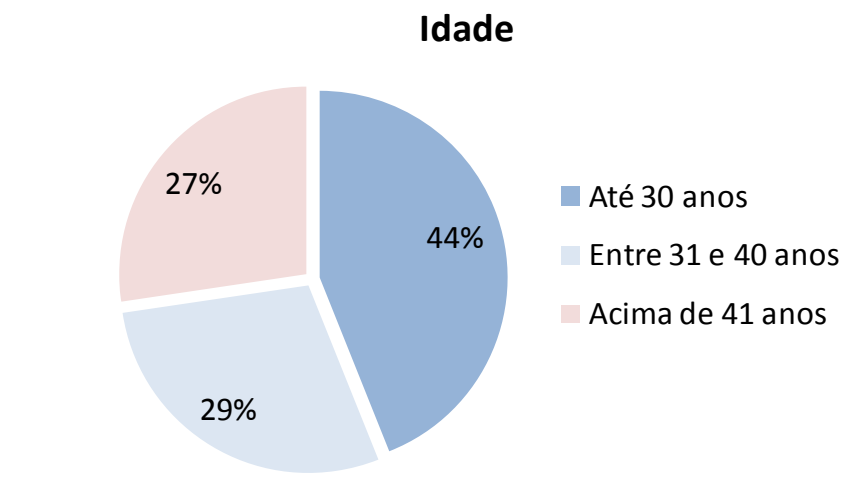

Figura 11 - Distribuição dos respondentes segundo a faixa de idade.

Embora originada pelos dados de nascimento, apresentamos a distribuição das idades segundo as faixas etárias. Esta transformação da variável métrica em categórica foi necessária para facilitar análises posteriores deste estudo.

Da mesma forma notamos o mesmo comportamento no gráfico de ano de formação, visto que os alunos tendem a apresentar idades semelhantes ao concluírem o curso.

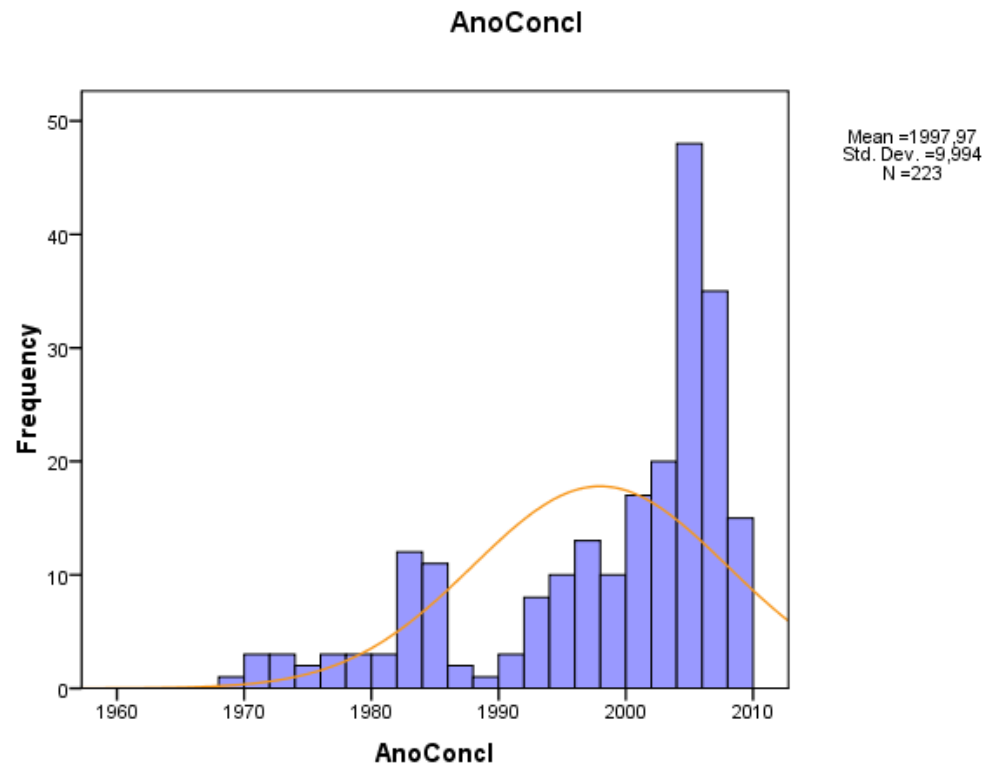

Figura 12 - Ano de conclusão.

A moda é para o ano de 2004 com 23 respondentes, e a mediana é para o ano de 2002 . A média é basicamente 1998 (arredondamento de 1997,97) e o desvio padrão manteve-se quase no mesmo patamar, 9,994 .

O gráfico abaixo apresenta a distribuição dos respondentes conforme o curso de graduação. Esta questão também era de resposta obrigatória, portanto não houve respostas em branco. 


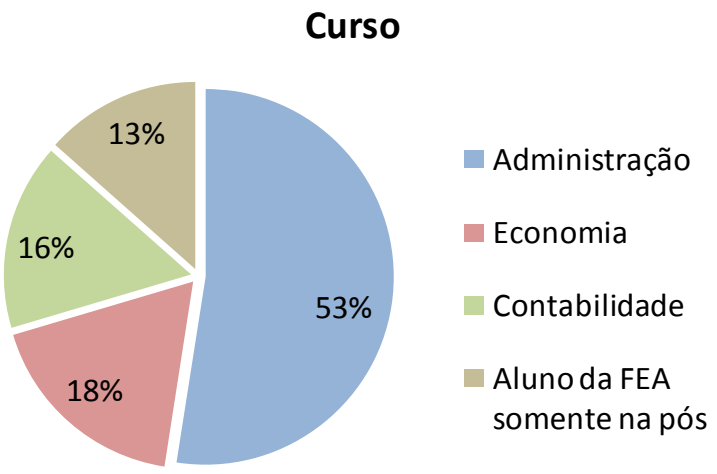

Figura 13 - Distribuição dos respondentes em relação ao curso de graduação na FEA.

Nota-se uma forte concentração dos alunos que cursaram administração na graduação. Embora seja o departamento com mais alunos da graduação, o que corresponde a quase $40 \%$ dos alunos de graduação ${ }^{15}$, 53\% está acima do esperado. Economia e Contabilidade, respeitam a ordem em número de alunos. Em relação aos alunos da pós-graduação que não fizeram a faculdade na FEA, preferiu-se tratá-los em um grupo específico, uma vez que os mesmos apresentam diversas formações possíveis.

Explorando-se mais profundamente a formação dos respondentes, perguntou-se qual era a formação máxima obtida. O gráfico abaixo traz as respostas de forma desagregada e agregada.

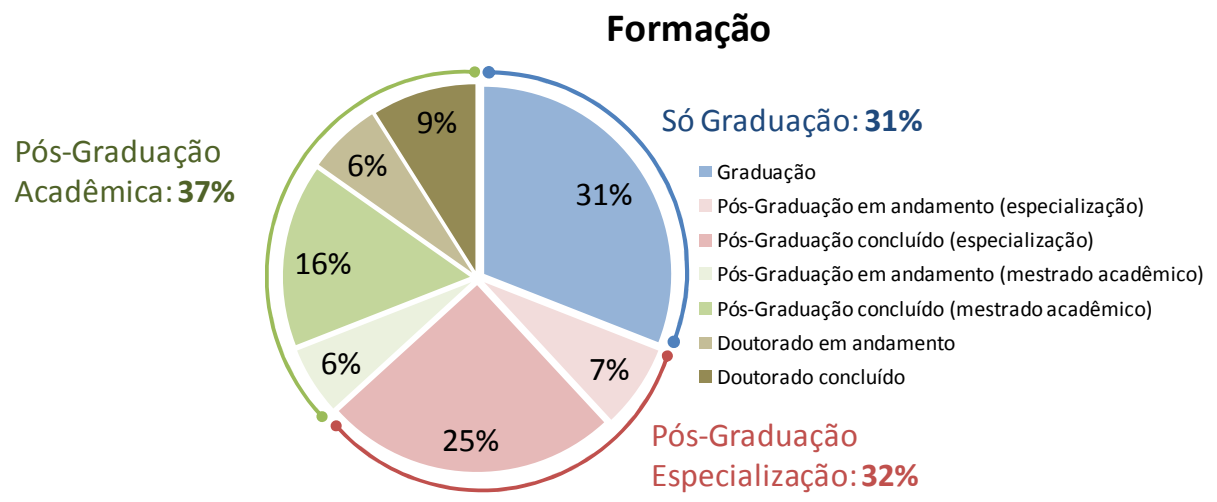

Figura 14 - Distribuição dos respondentes segundo a formação.

Analisando os grupos da distribuição desagregados, os respondentes que fizeram somente a graduação é o mais expressivo, com 31\%, seguidos dos respondentes que encerraram uma pós-graduação do tipo lato sensu (especialização), 25\%, e dos que concluíram a pósgraduação stricto sensu em mestrado, 16\%. Porém, analisando os dados agregados, a situação se inverte. O número de respondentes que seguiram a trajetória acadêmica é a maior com

\footnotetext{
${ }^{15}$ Fonte: FEA-USP (2008).
} 
$37 \%$, seguida pelos que optaram pela especialização, 32\%. Sob este ponto de vista, é possível afirmar que $69 \%$ dos respondentes não encerraram a formação após a graduação.

É válido lembrar que no tratamento dos dados foram eliminados 7 ex-alunos que se dedicam integralmente aos estudos e não desempenham atividades profissionais no momento. Somente dos que estão cursando doutorado, teríamos 5 respondentes a mais.

Deste mesmo conjunto de respostas, podemos gerar uma nova informação combinando apenas os resultados. No gráfico abaixo separamos os respondentes que estão cursando alguma pós no momento e os que não estão.

\section{Está cursando alguma pós}

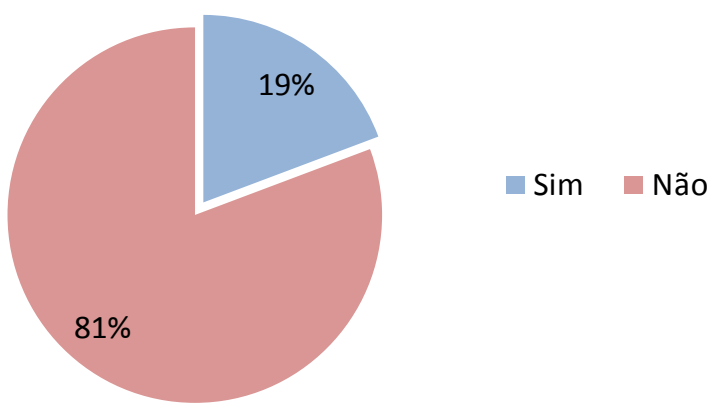

Figura 15 - Distribuição dos respondentes segundo o fato de estar cursando alguma pós.

O conjunto das pessoas que estão cursando alguma pós é de $19 \%$, número que poderia ser maior se considerássemos os estudantes de tempo integral, conforme já citado.

Em relação ao aspecto geográfico, foi questionado a cidade, estado e país de residência. A partir da combinação destas três variáveis foi possível construir o próximo gráfico.

\section{Onde mora}

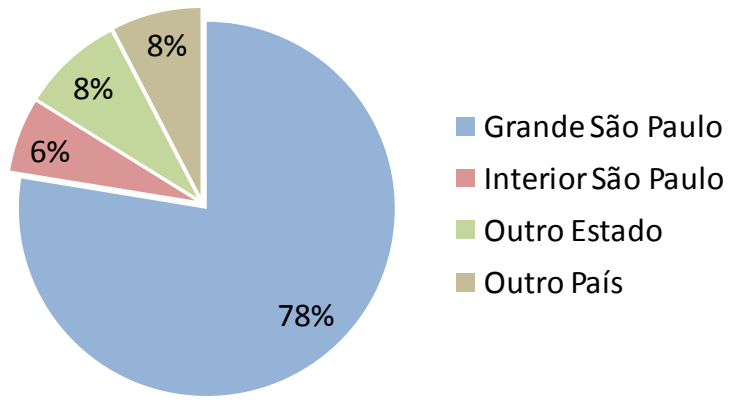

Figura 16 - Distribuição dos respondentes segundo local de residência. 
Grande São Paulo congrega a cidade de São Paulo e as cidades ao redor, representa a grande maioria dos respondentes, cerca de $78 \%$ dos respondentes. Em outras palavras, poderíamos dizer que quatro quintos dos formados respondentes permanecem na capital e os demais vão para outras cidades, estados e países de forma distribuída.

O próximo gráfico apresenta o Status profissional dos respondentes.

\section{Status Profissional}

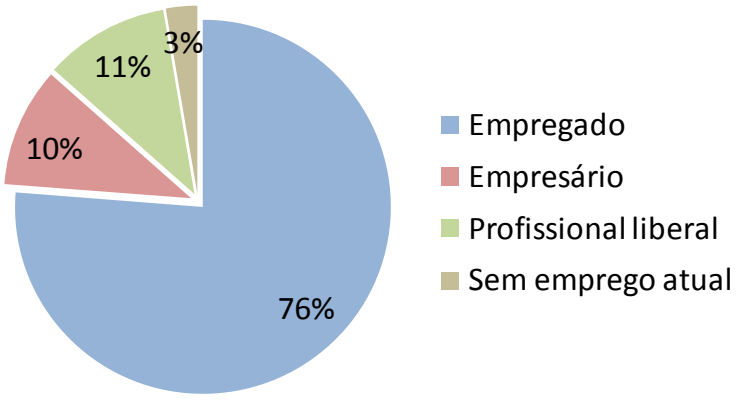

Figura 17 - Distribuição dos respondentes segundo o Status profissional.

Três quartos dos respondentes são empregados em organizações. Já em relação àqueles que buscaram suas próprias oportunidades, temos $10 \%$ de empresários e $11 \%$ de profissionais liberais. Somente 3\% dos respondentes estão sem emprego atual, ou em fase de transição em suas carreiras.

A seguir, apresentamos a distribuição dos respondentes de acordo com os diversos níveis hierárquicos.

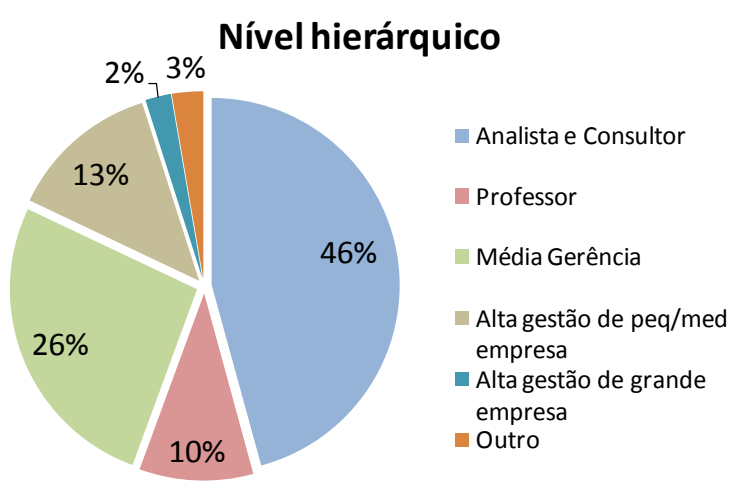

Figura 18 - Distribuição dos respondentes segundo o nível hierárquico.

Buscou-se reduzir o número de grupos, por isso o número possível de 21 opções apresentadas no questionário foi reduzido para 6 grupos. O grupo mais representativo, analista e consultor, 
representa os níveis: Analista (53 respondentes), Consultor (24 respondentes), Trainee (6 respondentes), Auditor (4 respondentes), Especialista (3 respondentes), Técnico (2 respondentes), Assistente (1 respondente). O critério para reuni-las foi a característica comum de contribuidores individuais.

Na mesma linha, a média gerência reúne os níveis: Gerente (39 respondentes), Coordenador (15 respondentes) e Supervisor (1 respondente). O critério de agrupamento foi o de coordenar recursos para o cumprimento de metas.

A alta gestão compreende os níveis: Sócio (18 respondentes), Diretor (12 respondentes), Presidente (1 respondente), Vice-Presidente (1 respondente) e Superintendente (1 respondente). Pela distinção clara dentre um alto gestor de uma pequena/média empresa para uma grande, dividimos em dois grupos distintos, combinando a questão de porte da empresa.

Professor é um grupo distinto representativo, 10\% dos respondentes. Em outros entraram todos aqueles que se declararam com o nível outro e não especificaram no campo texto “outros" no questionário. Os níveis Chefe, Conselheiro e Secretário não foram assinalados por ninguém.

Os próximos três gráficos estão relacionados às características da organização em que o indivíduo trabalha. Neste conjunto de perguntas, o respondente não tinha a obrigatoriedade na resposta.

O primeiro gráfico apresenta o porte da organização.

\section{Porte da organização}

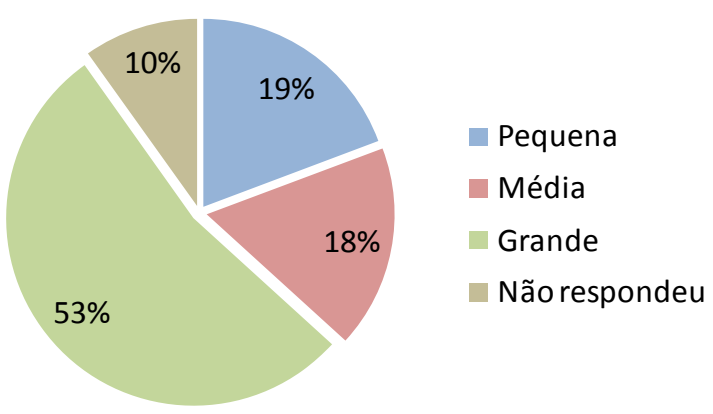

Figura 19 - Distribuição dos respondentes segundo o porte da organização. 
Mais da metade dos respondentes, 53\%, assinalaram a opção de que eles trabalham em grandes organizações. Com quase um quinto de respostas cada, temos a pequena empresa (18\%) e a média empresa (18\%). A taxa de respostas em branco foi de $10 \%$.

O próximo gráfico apresenta os setores destas organizações. Preferiu-se colocar o número de respondentes a porcentagem, por conta da grande variedade de respostas possíveis.

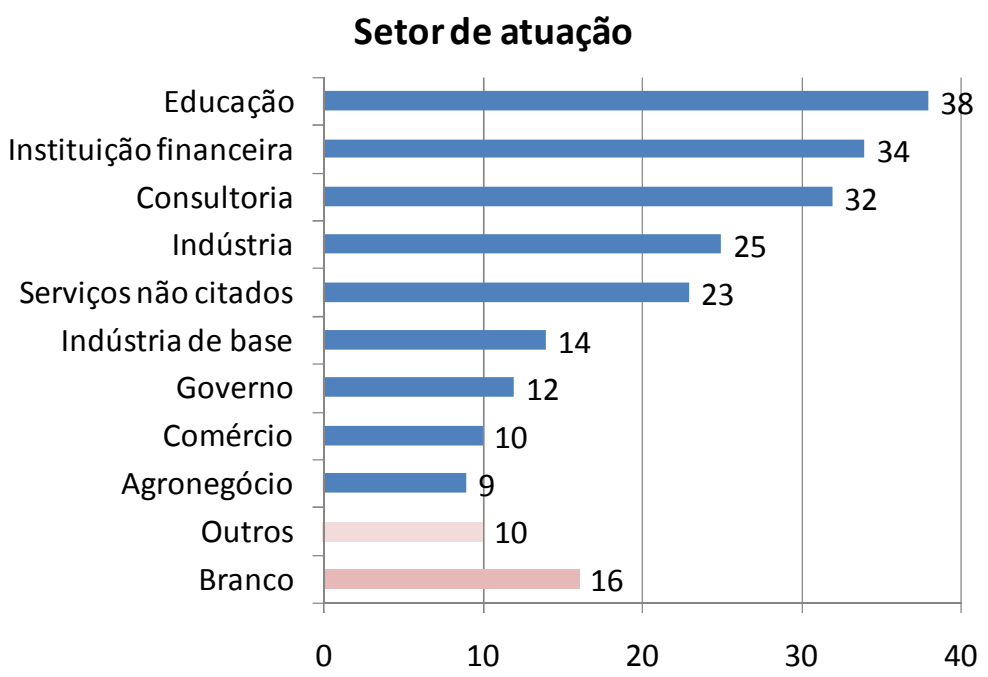

Figura 20 - Distribuição das empresas dos respondentes segundo os setores de atuação.

Os setores mais significativos estão atrelados ao setor de serviços e por isso foram desmembrados para destacar a sua importância. O número de professores e dirigentes de instituições de ensino fez com que o setor de Educação fosse o mais representativo (38 respondentes). O setor que corresponde às instituições financeiras (Bancos comerciais e múltiplos; Bancos de investimentos; Previdência complementar; Seguradoras; e, Outras instituições financeiras) tem 34 respondentes, seguido das Consultorias, que têm 32 dos respondentes.

As indústrias (Automotivo (montadoras e autopeças); Brinquedos; Confecções, têxteis e moda; Cosméticos; Couro e calçado; Eletroeletrônico e computadores; Higiene; Farmacêutico; Limpeza; e, Moveleiro) formam o quarto grupo mais relevante com 25 respondentes.

Os demais serviços, desconsiderando Educação, Instituições Financeiras e Consultorias correspondem a 23 respondentes. Este grupo compreende: Comunicações; Cultura; 
Entretenimento; Esporte; Hotéis, bares e restaurantes; Saúde (hospitais e afins); Telecomunicações; Tecnologia e informática; Transporte e logística; e, Turismo.

É válido mencionar um vestígio de viés desta amostra, devido à elevada participação dos atuantes no setor do ensino, talvez pelo fato deles serem mais propensos a contribuírem com pesquisas. Na pesquisa de Cassimiro (2004), as mesmas opções de setores foram utilizadas para 238 respondentes e o resultado foi um pouco diferente. $\mathrm{O}$ setor financeiro foi o mais relevantes com 42 respondentes e o setor de consultoria foi o segundo com 26 respondentes. O setor de educação foi o quarto com apenas 13 respondentes. Por outro lado, a pesquisa de Cassimiro (2004) era em relação somente aos ex-alunos com menos de 5 anos de formação, ou seja, faixa etária jovem para ser professor. Por conta das finalidades deste estudo, não aprofundamos esta análise.

Em relação ao tipo de organização, o gráfico abaixo apresenta a distribuição dos empregadores.

Tipo de organização

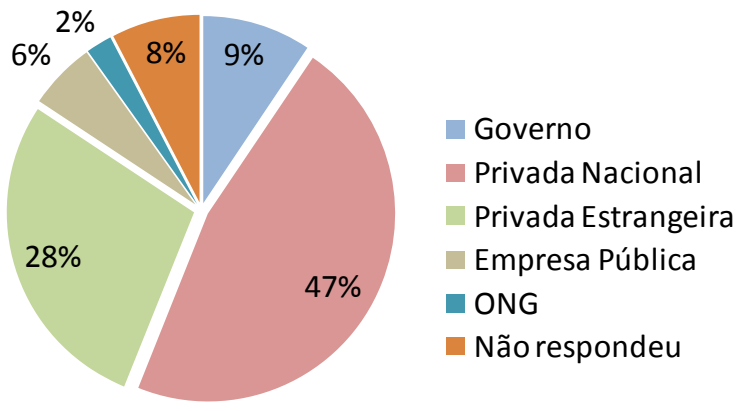

Figura 21 - Distribuição das empresas dos respondentes segundo a origem do capital.

Quase metade dos respondentes disse trabalhar para organizações privadas de capital nacional. Vinte e oito por cento dos respondentes trabalham para organizações privadas de capital estrangeiro. O restante dos respondentes está distribuído no Governo (9\%), Empresa Pública (6\%) e ONGs (2\%). O índice de não respondentes foi de $8 \%$ nesta questão.

O histograma abaixo apresenta a distribuição dos respondentes segundo o tempo de vínculo com a organização atual. 


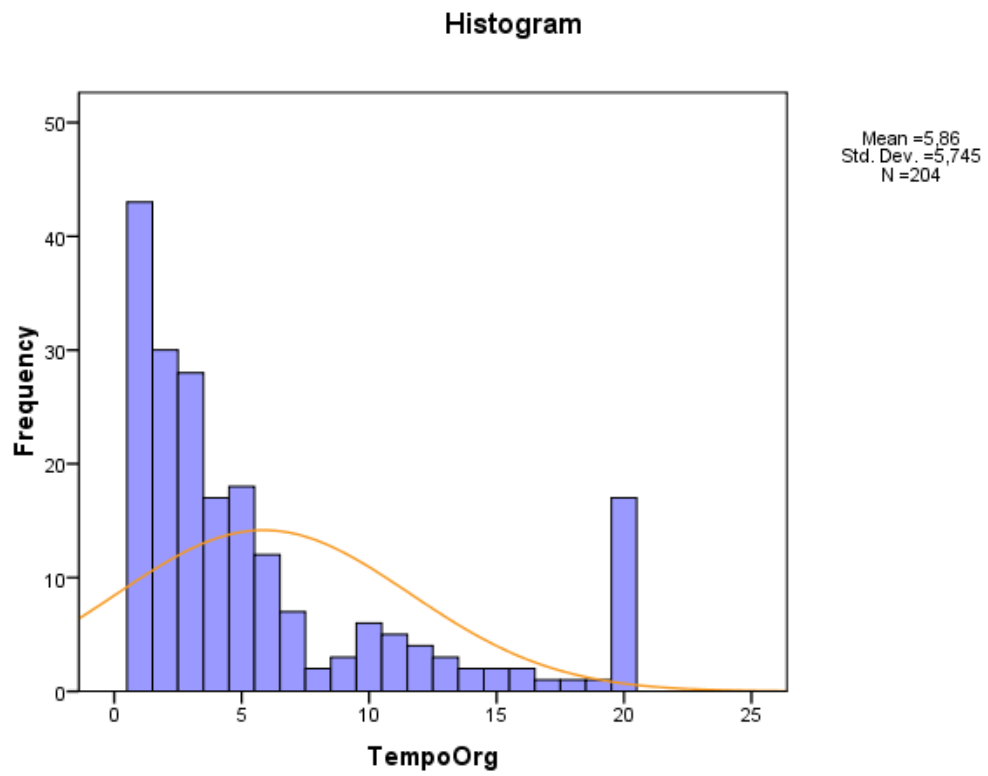

Figura 22 - Histograma da distribuição dos respondentes segundo o tempo na organização.

Deste gráfico é importante mencionar que a concentração na resposta "20 anos ou mais" não foi planejada, o que inviabiliza a consideração desta variável como sendo uma variável numérica, portanto desconsideraremos o cálculo da média e do desvio padrão. No entanto, o gráfico a seguir corrige o problema transformando a variável para categórica:

\section{Tempo na organização}

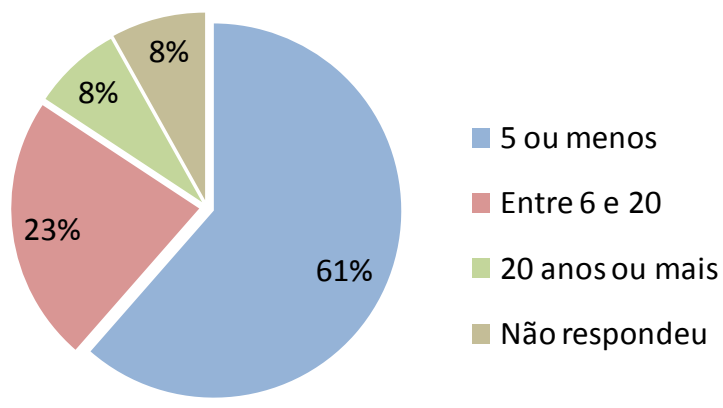

Figura 23 - Distribuição dos respondentes segundo o tempo na organização.

Neste gráfico, reunimos os dados anteriores em 3 grupos: 5 anos ou menos (com 61\%); Entre 6 e 20 anos (23\%); 20 anos ou mais (8\%). Nesta questão, $8 \%$ dos respondentes a deixaram em branco. Para efeitos estatísticos, consideraremos estas variáveis e não as anteriores para a análise.

Por conta da imensa variedade das ocupações funcionais e do elevado número da alternativa “outros”, preferiu-se desconsiderar da análise esta questão. 
Por fim, analisaremos neste bloco também a primeira pergunta do questionário. Buscou-se entender se alguma das três competências se sobressaia em relação às demais, como sendo mais requeridas para o dia a dia no trabalho. Abaixo segue o gráfico boxplot, ou gráfico de caixas, ideal para examinar as diferenças de grupos:

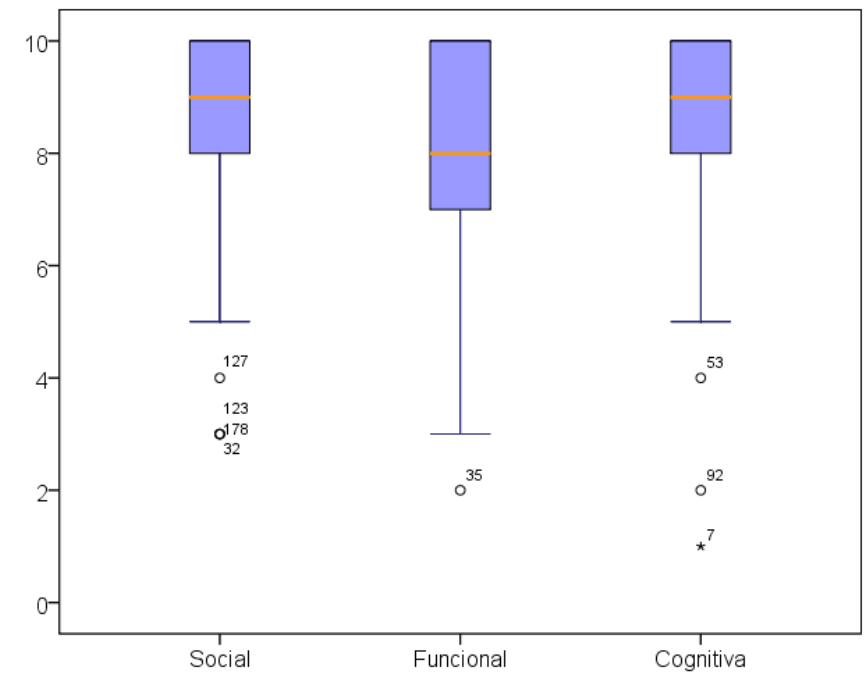

Figura 24 - Gráfico de caixas para a significância da competência para o trabalho.

A leitura deste gráfico é a seguinte: $50 \%$ das observações estão entre os limites da caixa, os quais representam o $25^{\circ}$ e o $75^{\circ}$ percentil dos dados; o traço interno representa o valor da mediana. As linhas que se estendem chamam-se whiskers e representam a distância à menor e à maior observação que estão a menos de um quartil da caixa. As observações atípicas (outliers) são os pontos destacados no gráfico, sendo os pequenos círculos observações que variam entre 1,0 e 1,5 quartis de distância da caixa, e os asteriscos, observações que estão a mais de 1,5 quartis do extremo da caixa.

Pela ausência de whiskers superiores e pelas medianas próximas, denota-se que houve uma grande aglomeração próxima ao escore máximo, inclusive a moda nas três competências é 10 . Isso nos leva a entender que todas as competências são relevantes para a o dia a dia do trabalho, embora a competência ligada à tarefa tenha média menor e desvio padrão maior (respectivamente, 8,22 e 1,575) em comparação à competência social (respectivamente, 8,77 e 1,495) e à competência cognitiva (respectivamente, 8,85 e 1,402).

Submetendo à um teste ANOVA, identificamos que há significância estatística (sig.: 0,00), ou seja, as médias ao longo dos grupos, em pelo menos uma é diferente. Ao verificar os testes 
Post Hoc de Bonferroni e Tukey B, notamos que o grupo 1 é composto pela Competência Funcional, enquanto que o grupo 2 tem-se as competências Social e Cognitiva. Logo, somente a média da Competência Funcional é que destoa entre as três. O quadro abaixo apresenta a análise Tukey B:

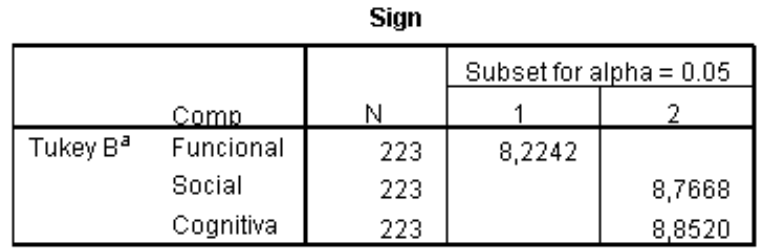

Means for groups in homogeneous subsets are displayed.

a. Uses Harmonic Mean Sample Size = 223,000.

Quadro 17 - Teste Tukey B para a significância das competências para o trabalho.

As médias apresentadas são diferentes das médias apresentadas na Figura 24 - Gráfico de caixas para a significância da competência para o trabalho., pois no teste de Tukey B considera a média harmônica e não a média aritmética.

Entretanto é necessário recorrer ao teste não paramétrico de Kruskal-Wallis, uma vez que o teste de Kolmogorov-Smirnov acusou que nem todos os grupos apresentam distribuição normal, já que o nível de significância foi de 0,000. Já para o teste de Levene, as variâncias são homogêneas, uma vez que o nível de significância foi de 0,064 .

Os resultados podem ser mantidos, já que o nível de significância do teste de Kruskal-Wallis foi de 0,000 .

\subsection{Teste das Hipóteses}

Antes em testarmos as hipóteses, apresentamos o quadro abaixo que reúne estatísticas descritivas de frequências, geradas pelo SPSS e adaptadas para melhor visualização e comparação. 


\begin{tabular}{|c|c|c|c|c|}
\hline & Competência Social & Competência Funcional & Competência Cognitiva & Metacompetência \\
\hline 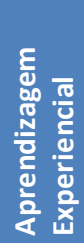 & $\begin{array}{l}\text { Média: } 8,55 \\
\text { Mediana: } 9 \\
\text { Moda: } 10 \\
\text { Desvio Padrão: } 1,824 \\
\text { Variância: } 3,326\end{array}$ & $\begin{array}{l}\text { Média: } 8,68 \\
\text { Mediana: } 9 \\
\text { Moda: } 10 \\
\text { Desvio Padrão: } 1,564 \\
\text { Variância: } 2,445\end{array}$ & $\begin{array}{l}\text { Média: } 8,69 \\
\text { Mediana: } 9 \\
\text { Moda: } 10 \\
\text { Desvio Padrão: } 1,585 \\
\text { Variância: } 2,512\end{array}$ & $\begin{array}{l}\text { Média: } 8,25 \\
\text { Mediana: } 9 \\
\text { Moda: } 10 \\
\text { Desvio Padrão: } 1,964 \\
\text { Variância: } 3,857\end{array}$ \\
\hline 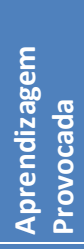 & $\begin{array}{l}\text { Média: } 7,56 \\
\text { Mediana: } 8 \\
\text { Moda: } 8 \\
\text { Desvio Padrão: } 2,032 \\
\text { Variância: } 4,130\end{array}$ & $\begin{array}{l}\text { Média: } 7,41 \\
\text { Mediana: } 8 \\
\text { Moda: } 8 \\
\text { Desvio Padrão: } 2,080 \\
\text { Variância: } 4,325\end{array}$ & $\begin{array}{l}\text { Média: } 7,52 \\
\text { Mediana: } 8 \\
\text { Moda: } 8 \\
\text { Desvio Padrão: } 1,945 \\
\text { Variância: } 3,782\end{array}$ & $\begin{array}{l}\text { Média: } 7,48 \\
\text { Mediana: } 8 \\
\text { Moda: } 8 \\
\text { Desvio Padrão: } 2,276 \\
\text { Variância: 5,178 }\end{array}$ \\
\hline 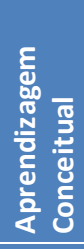 & $\begin{array}{l}\text { Média: } 5,20 \\
\text { Mediana: } 5 \\
\text { Moda: } 7 \\
\text { Desvio Padrão: 2,482 } \\
\text { Variância: } 6,161\end{array}$ & $\begin{array}{l}\text { Média: } 5,83 \\
\text { Mediana: } 6 \\
\text { Moda: } 7 \\
\text { Desvio Padrão: } 2,392 \\
\text { Variância: } 5,722\end{array}$ & $\begin{array}{l}\text { Média: } 6,82 \\
\text { Mediana: } 7 \\
\text { Moda: } 8 \\
\text { Desvio Padrão: } 2,284 \\
\text { Variância: } 5,219\end{array}$ & $\begin{array}{l}\text { Média: } 7,28 \\
\text { Mediana: } 8 \\
\text { Moda: } 8 \\
\text { Desvio Padrão: } 2,372 \\
\text { Variância: } 5,628\end{array}$ \\
\hline 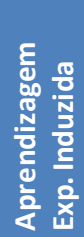 & $\begin{array}{l}\text { Média: } 4,60 \\
\text { Mediana: } 5 \\
\text { Moda: } 1 \\
\text { Desvio Padrão: } 2,647 \\
\text { Variância: } 7,006\end{array}$ & $\begin{array}{l}\text { Média: 5,49 } \\
\text { Mediana: } 6 \\
\text { Moda: } 1 \\
\text { Desvio Padrão: 2,757 } \\
\text { Variância: } 7,604\end{array}$ & $\begin{array}{l}\text { Média: } 6,40 \\
\text { Mediana: } 7 \\
\text { Moda: } 8 \\
\text { Desvio Padrão: } 2,630 \\
\text { Variância: } 6,914\end{array}$ & $\begin{array}{l}\text { Média: } 6,14 \\
\text { Mediana: } 7 \\
\text { Moda: } 7 \\
\text { Desvio Padrão: } 2,678 \\
\text { Variância: } 7,174\end{array}$ \\
\hline
\end{tabular}

Quadro 18 - Avaliação dos grupos de eventos de aprendizagem pelas competências.

A ordem dos grupos de eventos de aprendizagem foi propositalmente alterada para que representassem a importância obtida pela média. Nota-se que a mesma sequência persiste para todas as competências. Em primeiro temos a Aprendizagem Experiencial como sendo a mais importante, seguida pela Aprendizagem Provocada e pela Aprendizagem Conceitual. Em última posição, temos a Aprendizagem Experiencial Induzida.

Entretanto, esta conclusão só pode ser estatisticamente comprovada pelo teste ANOVA, pois embora as médias sejam um indicador inicial, as variâncias podem gerar outras interpretações. Abaixo apresentamos os resultados dos testes de significância encontrados.

\begin{tabular}{|l|l|l|l|l|}
\hline Competências & ANOVA & Levene & $\begin{array}{l}\text { Kolmogorov- } \\
\text { Smirnov }\end{array}$ & Kruskal-Wallis \\
\hline Comp. Social & 0,000 & 0,000 & 0,000 & 0,000 \\
\hline Comp. Funcional & 0,000 & 0,000 & 0,000 & 0,000 \\
\hline Comp. Cognitiva & 0,000 & 0,000 & 0,000 & 0,000 \\
\hline Metacompetência & 0,000 & 0,000 & 0,000 & 0,000 \\
\hline
\end{tabular}

Quadro 19 - Valores de significâncias dos testes estatísticos para as competências. 
Ao processar o teste ANOVA individualmente para cada competência, todas apresentaram significância estatística de 0,000 . Logo, a média em pelo menos uma das variáveis é diferente. Entretanto, os pressupostos de homogeneidade das variâncias entre os grupos e de normalidade para cada grupo foram violados, respectivamente pelos testes de Levene e Kolmogorov-Smirnov.

Quando um destes pressupostos é rompido, é necessário recorrer ao teste não-paramétrico de Kruskal-Wallis, o qual neste caso corroborou os resultados da ANOVA, ou seja, apesar da heteroscedasticidade e da não-normalidade presentes, os resultados da ANOVA continuam válidos graças ao teste de Kruskal-Wallis.

Na ANOVA, o teste Post Hoc de Tukey B foi considerado para estudar se os grupos de eventos de aprendizagem mantêm a mesma seqüência apresentada no Quadro 18 - Avaliação dos grupos de eventos de aprendizagem pelas competências. e se apresentam médias distintas. Abaixo os quadros com os testes:

\begin{tabular}{|c|c|c|c|c|c|c|}
\hline \multicolumn{7}{|c|}{ Concor } \\
\hline & \multirow[b]{2}{*}{ Aprend } & \multirow[b]{2}{*}{$N$} & \multicolumn{4}{|c|}{ Subset for alpha $=0.05$} \\
\hline & & & 1 & 2 & 3 & 4 \\
\hline \multirow[t]{4}{*}{ 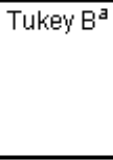 } & Explnd1Social & 223 & 4,2287 & & \multirow{4}{*}{7,5605} & \multirow[b]{4}{*}{8,5067} \\
\hline & Conc1Social & 223 & & 5,1300 & & \\
\hline & Prov1 Social & 223 & & & & \\
\hline & Exp1Social & 223 & & & & \\
\hline
\end{tabular}

Means for groups in homogeneous subsets are displayed.

a. Uses Harmonic Mean Sample size $=223,000$.

Quadro 20 - Teste Tukey B para Grupos de Eventos de Aprendizagem e Competência Social.

\begin{tabular}{|c|c|c|c|c|c|c|}
\hline \multicolumn{7}{|c|}{ Concor } \\
\hline & \multirow[b]{2}{*}{ Anrend } & \multirow[b]{2}{*}{$\mathrm{N}$} & \multicolumn{4}{|c|}{ Subset for alpha $=0.05$} \\
\hline & & & 1 & 2 & 3 & 4 \\
\hline \multirow[t]{4}{*}{ Tukey $\mathrm{B}^{\mathrm{a}}$} & Explnd2Func & 223 & 5,1166 & & \multirow{4}{*}{7,4126} & \multirow[b]{4}{*}{8,6771} \\
\hline & Conc2Func & 223 & & 5,7803 & & \\
\hline & Prov2func & 223 & & & & \\
\hline & Exp 2Func: & 223 & & & & \\
\hline
\end{tabular}

Means for groups in homogeneous subsets are displayed.

a. Uses Hamonic Mean Sample size $=223,000$.

Quadro 21 - Teste Tukey B para Grupos de Eventos de Aprendizagem e Competência Funcional. 


\begin{tabular}{|c|c|c|c|c|c|c|}
\hline \multicolumn{7}{|c|}{ Concor } \\
\hline & \multirow[b]{2}{*}{ Aspend } & \multirow[b]{2}{*}{$N$} & \multicolumn{4}{|c|}{ Subset for alpha = 0.05} \\
\hline & & & 1 & 2 & 3 & 4 \\
\hline \multirow[t]{4}{*}{ Tukey $\mathrm{B}^{\mathrm{a}}$} & Explnd3Cogn & 223 & 6,0852 & & \multirow{4}{*}{7,5157} & \multirow[b]{4}{*}{8,6906} \\
\hline & Conc30ogn & 223 & & 6,7623 & & \\
\hline & Prov3cogn & 223 & & & & \\
\hline & Exp30ogn & 223 & & & & \\
\hline
\end{tabular}

Weans for groups in homogeneous subsets are displayed.

a. Uses Harmonic Mean Sample Size $=223,000$.

Quadro 22 - Teste Tukey B para Grupos de Eventos de Aprendizagem e Competência Cognitiva.

\begin{tabular}{|c|c|c|c|c|c|}
\hline \multicolumn{6}{|c|}{ Conc } \\
\hline & \multirow[b]{2}{*}{ Anpend } & \multirow[b]{2}{*}{$N$} & \multicolumn{3}{|c|}{ Subset for alpha = 0.05} \\
\hline & & & 1 & 2 & 3 \\
\hline \multirow[t]{4}{*}{ Tukey $\mathrm{B}^{\mathrm{a}}$} & Explnd4meta & 223 & 5,7265 & & \\
\hline & Conc 4 weta & 223 & & 7,2108 & \\
\hline & Prov4lueta & 223 & & 7,4126 & \\
\hline & Exp 4weta & 223 & & & 8,1345 \\
\hline
\end{tabular}

Weans for groups in homogeneous subsets are displayed

a. Uses Harmonic Mean Sample Size $=223,000$.

Quadro 23 - Teste Tukey B para Grupos de Eventos de Aprendizagem e Metacompetência.

Em todos os testes a mesma seqüência também foi confirmada, ou seja, a Aprendizagem Induzida apresentou a média menor, seguida da Aprendizagem Conceitual e Aprendizagem Provocada. A maior média em todas as competências pertenceu a Aprendizagem Experiencial.

O teste Tukey B também cria conjuntos para as variáveis independentes representados por colunas nos quadros acima. O fato de haver quatro colunas, sendo um grupo de eventos de aprendizagem em cada, significa que todas as variáveis apresentam médias diferentes entre si. Somente no Quadro 23 - Teste Tukey B para Grupos de Eventos de Aprendizagem e Metacompetência. temos três colunas, isso porque para a Metacompetência, os grupos de eventos de aprendizagem Conceitual e Provocada apresentam médias populacionais não são significativamente diferentes.

Um outro teste utilizado para facilitar esta visualização é o de Bonferroni, apresentado abaixo: 
Multiple Comparisons

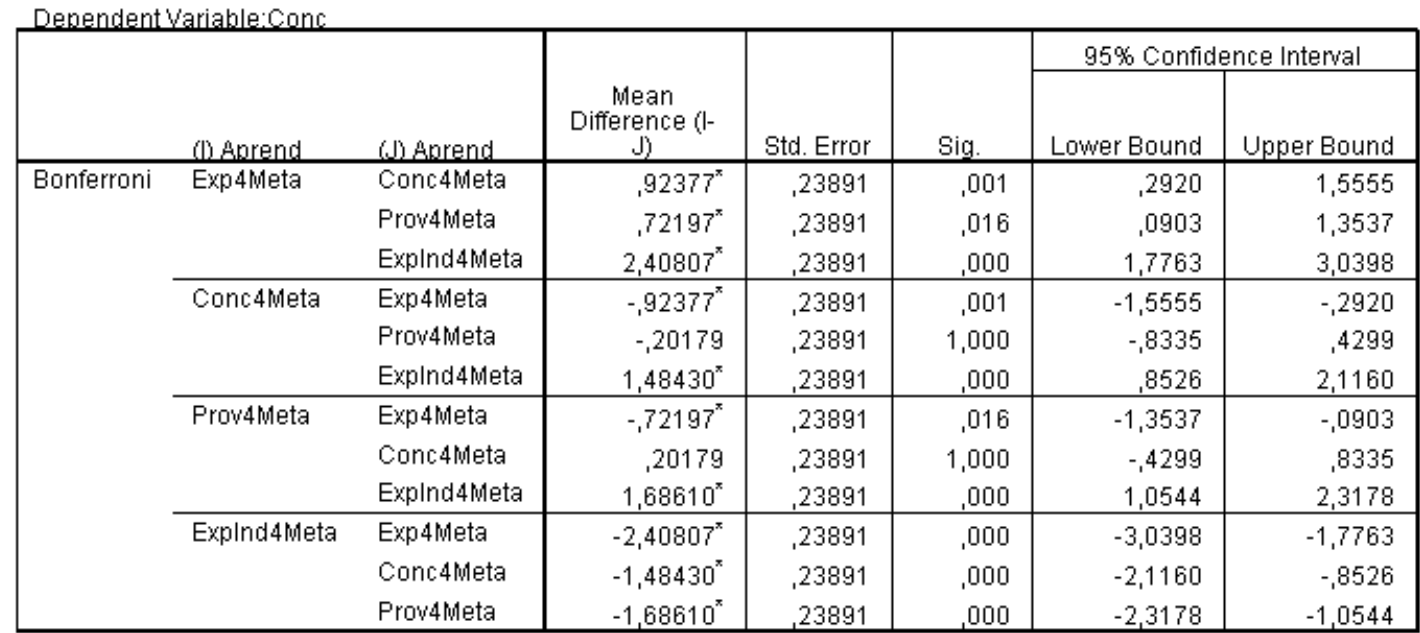

*. The mean difference is significant at the 0.05 lewel.

Quadro 24 - Teste Bonferroni para Grupos de Eventos de Aprendizagem e Metacompetência.

A leitura deste quadro é dirigida à coluna Sig. Para apresentarem médias estatisticamente diferentes, o Sig. deve ser menor que 0,05. Para a comparação entre as variáveis Aprendizagem Conceitual e Provocada o Sig. representa valor igual a 1, o que aceita a hipótese nula de que as médias populacionais são iguais.

Esta série de análises apresentadas nesta seção do trabalho já nos possibilita validarmos ou não as hipóteses desta pesquisa. O quadro resumo abaixo reúne todos os testes e justificativas:

\begin{tabular}{|c|c|c|}
\hline Hipótese & Aceita? & Justificativa \\
\hline $\begin{array}{l}\text { H01 - Os grupos de eventos } \\
\text { de aprendizagem informal são } \\
\text { os mais relevantes para o } \\
\text { desenvolvimento de } \\
\text { competências; }\end{array}$ & Sim & $\begin{array}{l}\text { Após constatar as ANOVAs com Sig. igual a } \\
0,00 \text {, todos os testes Post Hoc de Tukey B } \\
\text { apresentados pelos Quadro } 20 \text { - Teste Tukey B } \\
\text { para Grupos de Eventos de Aprendizagem e } \\
\text { Competência Social. a Quadro } 23 \text { - Teste Tukey } \\
\text { B para Grupos de Eventos de Aprendizagem e } \\
\text { Metacompetência. posicionam a Aprendizagem } \\
\text { Experiencial com a maior média. A } \\
\text { Aprendizagem Provocada está sempre com a } \\
\text { segunda maior média, entretanto na } \\
\text { Metacompetência apresenta posição } \\
\text { compartilhada com a Aprendizagem Conceitual. }\end{array}$ \\
\hline $\begin{array}{l}\text { H02 - Dentre os grupos de } \\
\text { eventos de aprendizagem } \\
\text { informal, destaca-se o grupo } \\
\text { de eventos Aprendizagem } \\
\text { Experiencial; }\end{array}$ & Sim & $\begin{array}{l}\text { Após constatar as ANOVAs com Sig. igual a } \\
0,00 \text {, todos os testes Post Hoc de Tukey B } \\
\text { apresentados pelos Quadro } 20 \text { - Teste Tukey B } \\
\text { para Grupos de Eventos de Aprendizagem e } \\
\text { Competência Social. a Quadro } 23 \text { - Teste Tukey } \\
\text { B para Grupos de Eventos de Aprendizagem e } \\
\text { Metacompetência. posicionam a Aprendizagem } \\
\text { Experiencial com a média acima da } \\
\text { Aprendizagem Provocada. }\end{array}$ \\
\hline
\end{tabular}




\begin{tabular}{|c|c|c|}
\hline Hipótese & Aceita? & Justificativa \\
\hline $\begin{array}{l}\text { H03 - Para o desenvolvimento } \\
\text { da Competência Cognitiva, o } \\
\text { grupo de eventos de } \\
\text { Aprendizagem Conceitual é o } \\
\text { mais importante; }\end{array}$ & Não & $\begin{array}{l}\text { Após constatar a ANOVA com Sig. igual a 0,00, } \\
\text { o teste Post Hoc de Tukey B apresentado no } \\
\text { Quadro } 22 \text { - Teste Tukey B para Grupos de } \\
\text { Eventos de Aprendizagem e Competência } \\
\text { Cognitiva.apresenta a Aprendizagem Conceitual } \\
\text { abaixo da Aprendizagem Experiencial e } \\
\text { Provocada. }\end{array}$ \\
\hline $\begin{array}{l}\text { H04 - Para o desenvolvimento } \\
\text { da Competência Funcional, o } \\
\text { grupo de eventos de } \\
\text { Aprendizagem Experiencial é } \\
\text { o mais importante; }\end{array}$ & Sim & $\begin{array}{l}\text { Após constatar a ANOVA com Sig. igual a } 0,00 \text {, } \\
\text { o teste Post Hoc de Tukey B apresentado no } \\
\text { Quadro } 21 \text { - Teste Tukey B para Grupos de } \\
\text { Eventos de Aprendizagem e Competência } \\
\text { Funcional.apresenta a Aprendizagem } \\
\text { Experiencial com a maior média. }\end{array}$ \\
\hline $\begin{array}{l}\text { H05 - Para o desenvolvimento } \\
\text { da Competência Social, o } \\
\text { grupo de evento de } \\
\text { Aprendizagem Experiencial é } \\
\text { o mais importante; }\end{array}$ & Sim & $\begin{array}{l}\text { Após constatar a ANOVA com Sig. igual a 0,00, } \\
\text { o teste Post Hoc de Tukey B apresentado no } \\
\text { Quadro } 20 \text { - Teste Tukey B para Grupos de } \\
\text { Eventos de Aprendizagem e Competência } \\
\text { Social.apresenta a Aprendizagem Experiencial } \\
\text { com a maior média. }\end{array}$ \\
\hline $\begin{array}{l}\text { H06 - Para o desenvolvimento } \\
\text { da metacompetência, o grupo } \\
\text { de eventos de Aprendizagem } \\
\text { Provocada é o mais } \\
\text { importante; }\end{array}$ & Não & $\begin{array}{l}\text { Após constatar a ANOVA com Sig. igual a 0,00, } \\
\text { o teste Post Hoc de Tukey B apresentado no } \\
\text { Quadro } 23 \text { - Teste Tukey B para Grupos de } \\
\text { Eventos de Aprendizagem e Metacompetência. } \\
\text { posiciona a Aprendizagem Experiencial com a } \\
\text { maior média. A Aprendizagem Provocada está } \\
\text { sempre com a segunda maior média, entretanto } \\
\text { apresenta posição compartilhada com a } \\
\text { Aprendizagem Conceitual. }\end{array}$ \\
\hline $\begin{array}{l}\text { H07 - O grupo de eventos de } \\
\text { Aprendizagem Experiencial } \\
\text { Induzido é o menos } \\
\text { importante. }\end{array}$ & Sim & $\begin{array}{l}\text { Após constatar as ANOVAs com Sig. igual a } \\
\text { 0,00, todos os testes Post Hoc de Tukey B } \\
\text { apresentados pelos Quadro } 20 \text { - Teste Tukey B } \\
\text { para Grupos de Eventos de Aprendizagem e } \\
\text { Competência Social. a Quadro } 23 \text { - Teste Tukey } \\
\text { B para Grupos de Eventos de Aprendizagem e } \\
\text { Metacompetência. posicionam a Aprendizagem } \\
\text { Experiencial Induzida com a menor média. }\end{array}$ \\
\hline
\end{tabular}

\subsection{Aprofundamento da Análise}

Após as hipóteses terem sido testadas, cabe a esta seção aprofundar a análise.

A primeira curiosidade que surge é o que aconteceria se avaliássemos se há diferenças de médias entre um grupo de evento de aprendizagem ao longo das competências. Para isso, recorremos novamente ao teste ANOVA. 
Começaremos pelo quadro resumo dos testes estatísticos.

\begin{tabular}{|l|l|l|l|l|}
\hline $\begin{array}{l}\text { Grupos de Eventos } \\
\text { de Aprendizagem }\end{array}$ & ANOVA & Levene & $\begin{array}{l}\text { Kolmogorov- } \\
\text { Smirnov }\end{array}$ & Kruskal-Wallis \\
\hline Experiencial & 0,004 & 0,001 & 0,000 & 0,042 \\
\hline Provocada & 0,841 & 0,064 & 0,000 & 0,858 \\
\hline Conceitual & 0,000 & 0,253 & 0,000 & 0,000 \\
\hline Experiencial Induzida & 0,000 & 0,633 & 0,000 & 0,000 \\
\hline
\end{tabular}

Quadro 26 - Valores de significâncias dos testes estatísticos para os Grupos de Eventos de Aprendizagem.

Como se nota pelo quadro acima, os resultados não apresentaram a mesma similaridade das análises anteriores, portanto analisaremos cada resultado em separado. Daremos início pela Aprendizagem Experiencial.

A ANOVA apresentou significância estatística de 0,004, o que justifica a diferença de pelo menos uma média. Apesar de apresentar heteroscedasticidade ${ }^{16}$ (sig. $\left.<0,05\right)$ e nãonormalidade (sig. $<0,05$ ), o teste de Kruskal-Wallis confere os achados da ANOVA.

No teste Post Hoc de Tukey B, apresentado abaixo, notamos que só surgiram dois conjuntos de variáveis.

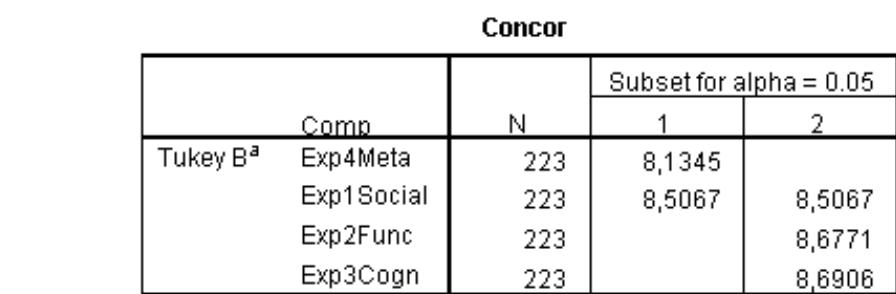

Means for groups in homogeneous subsets are displayed.

a. Uses Harmonic wean Sample Size $=223,000$.

Quadro 27 - Teste Tukey B para Competências e Aprendizagem Experiencial.

O primeiro conjunto apresenta as médias mais baixas e reúne a Metacompetência e a Competência Social. O segundo conjunto reúne a Competência Funcional e a Cognitiva. A Competência Social também consta no segundo agrupamento, pois tanto para estas médias,

\footnotetext{
${ }^{16} \mathrm{O}$ termo foi encontrado escrito de duas formas: heteroscedasticidade e heterocedasticidade. A tradução de ambos remete ao termo em inglês: heteroscedasticity.
} 
quanto para o primeiro conjunto, esta apresenta indiferença de médias. Isso pode ser facilmente visualizado no próximo quadro.

\begin{tabular}{|c|c|c|c|c|c|c|c|}
\hline \multicolumn{8}{|c|}{ Multiple Comparisons } \\
\hline enenden & able:car & \multirow[b]{3}{*}{ (d) comp } & \multirow[b]{3}{*}{$\begin{array}{l}\text { Mean } \\
\text { Difference (I- } \\
\mathrm{J})\end{array}$} & \multirow[b]{3}{*}{ Std. Error } & \multirow[b]{3}{*}{ Big. } & & \\
\hline & \multirow[b]{2}{*}{ (l) Camp } & & & & & \multicolumn{2}{|c|}{$95 \%$ confidence Interval } \\
\hline & & & & & & Lower Bound & Upper Bound \\
\hline \multirow[t]{12}{*}{ Bonferroni } & \multirow[t]{3}{*}{ Exp1Social } & Exp2Func &,- 17040 & .17273 & 1,000 & -.6271 & .2863 \\
\hline & & Exp3oggn &,- 18386 & 17273 & 1,000 & -.6406 & .2729 \\
\hline & & Exp 4 Weta &, 37220 & 17273 & 189 &,- 0845 & 8289 \\
\hline & \multirow[t]{3}{*}{ Exp2Func } & Exp1 Social & .17040 & .17273 & 1,000 &,- 2863 & .6271 \\
\hline & & Exp30ogn &,- 01345 & 17273 & 1,000 & -.4702 & .4433 \\
\hline & & Exp 4 Meta & $54260^{\pi}$ & 17273 & .010 &, 0859 & 9993 \\
\hline & \multirow[t]{3}{*}{ Exp3cogn } & Exp1 Social &, 18386 & .17273 & 1,000 & -.2729 & .6406 \\
\hline & & Exp2Func: &, 01345 & 17273 & 1,000 &.,- 4433 & .4702 \\
\hline & & Exp 4 weta & $55605^{x}$ & 17273 & , 000 &, 0993 & 1,0128 \\
\hline & \multirow[t]{3}{*}{ Exp4liata } & Exp15ocial &,- 37220 & .17273 & 189 &,- 8289 &, 0845 \\
\hline & & Exp2Func: &,$- 54260^{\pi}$ &, 17273 &, 010 &,- 9993 &,- 0859 \\
\hline & & Exp3Cogn & $-.55605^{x}$ & 17273 & 000 & $-1,0128$ &,- 0993 \\
\hline
\end{tabular}

*. The mean difference is significant at the 0.05 level

Quadro 28 - Teste Bonferroni para Competências e Aprendizagem Experiencial.

Pelo teste Post Hoc de Bonferroni notamos que a Competência Social apresenta média indiferente para qualquer outra competência, pois todos os Sigs. são maiores que 0,05. Já para as seguintes, a Metacompetência é a única que destoa em relação a média, com Sigs. abaixo de 0,05 .

A Aprendizagem Provocada foi o único teste deste conjunto que apresentou significância estatística maior que 0,05 , ou seja 0,841 , no teste ANOVA. Quando isso ocorre, a hipótese nula de igualdade das médias é aceita. Além disso, apresentou não-normalidade na distribuição (sig. $<0,05)$ e a hipótese nula foi rejeitada pelo teste de Kruskal-Wallis (sig. > $0,05)$.

Mesmo assim, apresentaremos os resultados dos testes, pois é interessante que tenhamos o contra-exemplo do que temos até então visto. Note as diferenças nos quadros abaixo. 


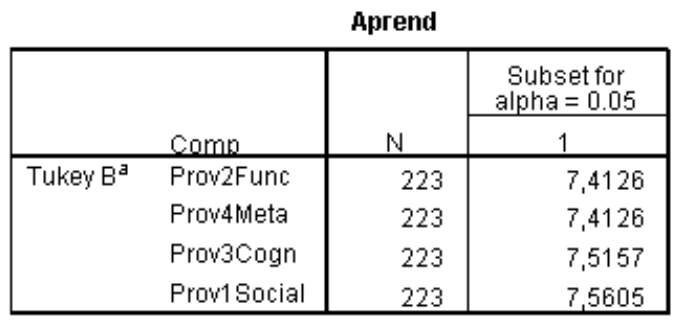

Means for groups in homogeneous subsets are displayed.

a. Uses Harmonic Mean Sample Size $=223,000$.

Quadro 29 - Teste Tukey B para Competências e Aprendizagem Provocada.

Multiple Comparisons

\begin{tabular}{|c|c|c|c|c|c|c|c|}
\hline & \multirow[b]{2}{*}{ d) comb } & \multirow[b]{2}{*}{ 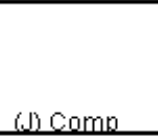 } & \multirow[b]{2}{*}{$\begin{array}{c}\text { Mean } \\
\text { Difference (l- } \\
\qquad\end{array}$} & \multirow[b]{2}{*}{ Std. Error } & \multirow[b]{2}{*}{ Sig. } & \multicolumn{2}{|c|}{$95 \%$ Confidence Interval } \\
\hline & & & & & & Lower Bound & Upper Bound \\
\hline \multirow[t]{12}{*}{ Banferroni } & \multirow[t]{3}{*}{ Prov15ocial } & Prov2Func: & .14798 & 20016 & 1,000 &,- 3813 & .6772 \\
\hline & & Prow3oggn & .04484 &, 20016 & 1,000 & -.4844 & .5741 \\
\hline & & Prow4lueta & .14798 &, 20016 & 1,000 & -.3813 & .6772 \\
\hline & \multirow[t]{3}{*}{ Prow2F unc } & Prow1Social &,- 14798 & .20016 & 1,000 & -.6772 &, 3813 \\
\hline & & Prow3ogn &,- 10314 &, 20016 & 1,000 &,- 6324 &, 4261 \\
\hline & & Prow4lweta & (00000 &, 20016 & 1,000 &.,- 5293 &, 5293 \\
\hline & \multirow[t]{3}{*}{ Prow3oogn } & Prow15ocial & -.04484 & .20016 & 1,000 &,- 5741 & .4844 \\
\hline & & Prow2Func: &, 10314 &, 20016 & 1,000 &,- 4261 &, 6324 \\
\hline & & Prow4heta &, 10314 &, 20016 & 1,000 & -.4261 & .6324 \\
\hline & \multirow[t]{3}{*}{ Prow4meta } & Prow1Social & -.14798 &, 20016 & 1,000 & -.6772 & .3813 \\
\hline & & Prov2Fune & , 00000 & .20016 & 1,000 & -.5293 & .5293 \\
\hline & & Prow3ogn & -10314 & 20016 & 1,000 & -.6324 & 4261 \\
\hline
\end{tabular}

Quadro 30 - Teste Bonferroni para Competências e Aprendizagem Provocada.

No teste Tukey B existe apenas um único conjunto, já que não houve diferenças significativas de médias e no teste de Bonferroni, todos Sigs. estão no valor máximo, ou seja 1.

Para a Aprendizagem Conceitual, o teste ANOVA apresentou significância de 0,000. E, apesar de apresentar não-normalidade (sig. $<0,05$ ), o teste de Kruskal-Wallis $($ sig. $<0,05)$ valida a ANOVA. Assim, foi possível identificar diferentes conjuntos, como mostra o teste Tukey B abaixo:

\begin{tabular}{|c|c|c|c|c|c|}
\hline \multicolumn{6}{|c|}{ Aprend } \\
\hline & \multirow[b]{2}{*}{ comb } & \multirow[b]{2}{*}{$\mathrm{N}$} & \multicolumn{3}{|c|}{ Bubset for alpha $=0.05$} \\
\hline & & & 1 & 2 & 3 \\
\hline \multirow[t]{4}{*}{ Tukey $\mathrm{B}^{\mathrm{a}}$} & Conc1Social & 223 & 5,1300 & \multirow{4}{*}{5,7803} & \\
\hline & Conc 2Func & 223 & & & \\
\hline & Conc3cogn & 223 & & & 6,7623 \\
\hline & Conc4weta & 223 & & & 7,2108 \\
\hline
\end{tabular}

Means for groups in homogeneous subsets are displayed.

a. Uses Harmonic Mean Sample Size $=223,000$. 
Duas variáveis foram nitidamente consideradas de forma isolada em conjuntos distintos. A Competência Social é a menos desenvolvida pela Aprendizagem Conceitual, seguida pela Competência Funcional. No terceiro conjunto, a Competência Cognitiva e Metacompetência apresentam médias até que consideravelmente distintas, porém em comparação com o Quadro 18 - Avaliação dos grupos de eventos de aprendizagem pelas competências.visto anteriormente, a variância de ambas variáveis são elevadas, 5,722 e 5,628, respectivamente. Isto justifica a não diferença de médias.

O quadro abaixo corrobora estas observações:

\begin{tabular}{|c|c|c|c|c|c|c|c|}
\hline \multicolumn{8}{|c|}{ Milutiple Comparisons } \\
\hline & \multirow[b]{2}{*}{ (h) comn } & \multirow[b]{2}{*}{ (1) camb } & \multirow[b]{2}{*}{$\begin{array}{c}\text { Mean } \\
\text { Difference (- } \\
ل\rangle\end{array}$} & \multirow[b]{2}{*}{ Std. Error } & \multirow[b]{2}{*}{ Big. } & \multicolumn{2}{|c|}{$95 \%$ confidence Interval } \\
\hline & & & & & & Lower Bound & Upper Bound \\
\hline \multirow[t]{12}{*}{ Bonferroni } & \multirow[t]{3}{*}{ Conc1Social } & Conc2Func &,$- 65022^{\pi}$ & .23221 &, 031 & $-1,2642$ &,- 0362 \\
\hline & & Conc3cogn & $-1,63229^{x}$ &, 23221 &, 000 & $-2,2463$ & $-1,0183$ \\
\hline & & Conc4weta & $-2,08072^{x}$ & 23221 &, 000 & $-2,6947$ & $-1,4667$ \\
\hline & \multirow[t]{3}{*}{ Conc2Func: } & Conc1Social & $.65022^{x}$ & 23221 &, 031 & .0362 & 1,2642 \\
\hline & & Conc $3 \operatorname{Cogn}$ & $-98206^{\circ}$ &, 23221 &, 000 & $-1,5961$ &,- 3681 \\
\hline & & Conctweta & $-1,43049^{x}$ & .23221 & , & $-2,0445$ & -.8165 \\
\hline & \multirow[t]{3}{*}{ Conc3Cogn } & Conc1Social & $1,63229^{\pi}$ & .23221 & 000 & 1,0183 & 2,2463 \\
\hline & & Conc2Func: & $98206^{\pi}$ & 23221 &, 000 &, 3681 & 1,5961 \\
\hline & & Conc4lweta & -.44843 & 23221 & 323 & $-1,0624$ & 1656 \\
\hline & \multirow[t]{3}{*}{ Conculibta } & Conc15ocial & $2,08072^{\pi}$ & 23221 &, 000 & 1,4667 & 2,6947 \\
\hline & & Conc2Func & $1,43049^{*}$ &, 23221 &, 000 & 8165 & 2,0445 \\
\hline & & Conc 3Cogn & 44843 & 23221 & 323 & -1656 & 1,0624 \\
\hline
\end{tabular}

*. The mean difference is significant at the 0.05 level.

Quadro 32 - Teste Bonferroni para Competências e Aprendizagem Conceitual.

Acima notamos que todas competências se diferem, com exceção da Competência Cognitiva e da Metacompetência.

$\mathrm{Na}$ Aprendizagem Experiencial Induzida voltamos a apresentar Significância 0,00 no teste ANOVA, não-normalidade e validação pelo teste de Kruskal-Wallis. Nos quadros a seguir, os testes Tukey B e Bonferroni. 


\begin{tabular}{|c|c|c|c|c|c|}
\hline \multicolumn{6}{|c|}{ Аргеnd } \\
\hline & \multirow[b]{2}{*}{ comb } & \multirow[b]{2}{*}{$\mathrm{N}$} & \multicolumn{3}{|c|}{ Subset for alpha = 0.05} \\
\hline & & & 1 & 2 & 3 \\
\hline \multirow[t]{4}{*}{ Tukey $\mathrm{B}^{\mathrm{a}}$} & Explnd1Gocial & 223 & 4,2287 & & \\
\hline & Explnd2F unc: & 223 & & 5,1166 & \\
\hline & Explnd4meta & 223 & & 5,7265 & 5,7265 \\
\hline & Explnd3Cogn & 223 & & & 6,0852 \\
\hline
\end{tabular}

Weans for groups in homogeneous subsets are displayed.

a. Uses Harmonic Wean Sample Size = 223,000.

Quadro 33 - Teste Tukey B para Competências e Aprendizagem Experiencial Induzida.

Como podemos notar, três conjuntos foram originados e apresentam como principais variáveis componentes, em ordem, Competência Social, Competência Funcional e Competência Cognitiva. A Metacompetência apresenta média sem diferença estatística tanto para o grupo 3, quanto para o grupo 4 .

\begin{tabular}{|c|c|c|c|c|c|c|c|}
\hline \multicolumn{8}{|c|}{ Multiple Comparisons } \\
\hline \multicolumn{8}{|c|}{ riable:anrend } \\
\hline & \multirow[b]{2}{*}{ (d) comn } & \multirow[b]{2}{*}{ (d) comb } & \multirow[b]{2}{*}{$\begin{array}{c}\text { Mean } \\
\text { Difference (I- } \\
\text { d) }\end{array}$} & \multirow[b]{2}{*}{ Std. Error } & \multirow[b]{2}{*}{ Sig. } & \multicolumn{2}{|c|}{$95 \%$ confidence Interval } \\
\hline & & & & & & Lower Bound & Upper Bound \\
\hline \multirow[t]{12}{*}{ Bonferroni } & \multirow[t]{3}{*}{ Explnd1Social } & Explnd2Func & $-.88789^{\pi}$ & .27840 &, 009 & $-1,6240$ &,- 1518 \\
\hline & & Explnd3cogn & $-1,85650^{\pi}$ & 27840 &, 000 & $-2,5926$ & $-1,1204$ \\
\hline & & Explnd4lweta & $-1,49776^{x}$ & 27840 &, 000 & $-2,2339$ &,- 7616 \\
\hline & \multirow[t]{3}{*}{ Explnd2Func } & Explnd1Social & $.88789^{x}$ & .27840 & .009 & 1518 & 1,6240 \\
\hline & & Explnd3cogn & $-96861^{x}$ &, 27840 &, 003 & $-1,7047$ & -.2325 \\
\hline & & Explnd4meta &,- 60987 &, 27840 & .172 & $-1,3460$ &, 1263 \\
\hline & \multirow[t]{3}{*}{ Explnd $3 \operatorname{Cogn}$} & Explnd1Social & $1,85650^{x}$ & .27840 & .000 & 1,1204 & 2,5926 \\
\hline & & Explnd2Func & $96861^{x}$ & .27840 &, 003 &, 2325 & 1,7047 \\
\hline & & Explnd4meta & 35874 & 27840 & 1,000 &,- 3774 & 1,0949 \\
\hline & \multirow[t]{3}{*}{ Explnd4Meta } & Explnd15ocial & $1,49776^{x}$ & .27840 & .000 & .7616 & 2,2339 \\
\hline & & Explnd2Func & 60987 & 27840 &, 172 &,- 1263 & 1,3460 \\
\hline & & Explnd3Cogn & -.35874 & 27940 & 1,000 & $-1,0949$ & 3774 \\
\hline
\end{tabular}

$*$ The mean difference is significant at the 0.05 level.

Quadro 34 - Teste Bonferroni para Competências e Aprendizagem Experiencial Induzida.

No quadro acima, a Metacompetência tem valores de significância acima de 0,00 para a Competência Funcional e a Cognitiva.

Uma análise de todos os quadros acima, permite-nos pensar da seguinte forma. $\mathrm{O}$ grupo de eventos de Aprendizagem Experiencial é o mais relevante no desenvolvimento de todas as competências, porém em relação entre elas, é um pouco menos para a Metacompetência. $\mathrm{O}$ grupo de eventos de Aprendizagem Provocada é o segundo mais relevante e representa o mesmo peso para todas as competências. Logo, os grupos de eventos de aprendizagem informal desenvolvem de forma mais relevante e geral todas as competências, 
Já os grupos de Eventos de Aprendizagem Formal desenvolvem menos todas as competências e são ainda menos relevantes para o desenvolvimento da Competência Social e da Competência Funcional, em especial para a primeira citada.

O quadro abaixo resume, como estes achados podem ser justificados:

\begin{tabular}{|c|c|}
\hline Achados & Justificativas \\
\hline $\begin{array}{l}\text { O grupo de eventos de Aprendizagem } \\
\text { Experiencial é o mais relevante no } \\
\text { desenvolvimento de todas as } \\
\text { competências, porém em relação entre } \\
\text { elas, é um pouco menos para a } \\
\text { metacompetência }\end{array}$ & $\begin{array}{l}\text { A relevância da aprendizagem experiencial pode ser } \\
\text { constatada como a principal pelos Quadro } 20 \text { - Teste } \\
\text { Tukey B para Grupos de Eventos de Aprendizagem e } \\
\text { Competência Social. a Quadro } 23 \text { - Teste Tukey B } \\
\text { para Grupos de Eventos de Aprendizagem e } \\
\text { Metacompetência.. A metacompetência é a que } \\
\text { apresenta a menor média e participação exclusiva no } \\
\text { primeiro conjunto do teste Tukey B no Quadro } 27 .\end{array}$ \\
\hline $\begin{array}{l}\text { O grupo de eventos de Aprendizagem } \\
\text { Provocada é o segundo mais relevante } \\
\text { e representa o mesmo peso para todas } \\
\text { as competências. }\end{array}$ & $\begin{array}{l}\text { A relevância da Aprendizagem Provocada pode ser } \\
\text { constatada como a segunda principal pelos Quadro } \\
20 \text { - Teste Tukey B para Grupos de Eventos de } \\
\text { Aprendizagem e Competência Social. a Quadro } 23 \text { - } \\
\text { Teste Tukey B para Grupos de Eventos de } \\
\text { Aprendizagem e Metacompetência.. O teste ANOVA } \\
\text { e o teste de Kruskal-Wallis comprovaram a não } \\
\text { diferença de médias, logo todas se encontram no } \\
\text { mesmo grupo do Tukey B no Quadro } 31 \text {. }\end{array}$ \\
\hline $\begin{array}{l}\text { Os grupos de eventos de } \\
\text { aprendizagem informal desenvolvem } \\
\text { de forma mais relevante e geral todas } \\
\text { as competências }\end{array}$ & $\begin{array}{l}\text { Combinação das duas justificativas anteriores. Além } \\
\text { disso, embora a Metacompetência tenha a menor } \\
\text { média em relação às demais competências, como } \\
\text { mostra Quadro 27, a Competência Experiencial é a } \\
\text { mais relevante, como mostra o Quadro } 23 \text {. }\end{array}$ \\
\hline $\begin{array}{l}\text { Os grupos de eventos de } \\
\text { Aprendizagem Formal desenvolvem } \\
\text { menos todas as competências e são } \\
\text { ainda menos relevantes para o } \\
\text { desenvolvimento da Competência } \\
\text { Social e da Competência Funcional, } \\
\text { em especial para a primeira citada. }\end{array}$ & $\begin{array}{l}\text { Do Quadro } 20 \text { - Teste Tukey B para Grupos de } \\
\text { Eventos de Aprendizagem e Competência Social. ao } \\
\text { Quadro } 23 \text { - Teste Tukey B para Grupos de Eventos } \\
\text { de Aprendizagem e Metacompetência. justifica-se a } \\
\text { primeira parte desta afirmação. Para a segunda parte, } \\
\text { os testes Tukey B, mostrados no Quadro } 31 \text { e Quadro } \\
\text { 33, posiciona a Competência Social no conjunto de } \\
\text { menor média e a Competência Funcional no segundo } \\
\text { conjunto de menor média. }\end{array}$ \\
\hline
\end{tabular}

Quadro 35 - Resumo dos achados dos testes ANOVA.

\subsection{Aprofundamento da Análise: Eventos de Aprendizagem}


Nesta seção do trabalho aprofundamos ainda mais a análise e estudamos os eventos de aprendizagem propriamente ditos. Os eventos são apresentados em quatro blocos, um para cada grupo, no qual há um painel que apresenta os gráficos de frequência dos eventos.

Na seqüência, apresentamos os resultados dos testes Qui-Quadradro entre os eventos de aprendizagem e as variáveis de perfil, a saber: Nascimento (categorizada) ${ }^{17}$, Curso, Formação, Cursa alguma pós, Onde mora, Status profissional, Nível hierárquico, Porte da organização, Setor da organização, Tipo de organização e Tempo na organização (categorizada).

Por fim, para os Qui-Quadrados mais significativos, apresentaremos mapas perceptuais gerados a partir do teste de Análise de Correspondência (ANACOR) para facilitar a interpretação desta relação. Embora o SPSS gere diversas tabelas para analisar a ANACOR, apresentaremos somente este mapa, pois de certa forma resume todas as informações relevantes. Além disso, buscou-se a praticidade, uma vez que a quantidade de relações que são vistas é grande e que o entendimento destas relações não é o foco principal deste estudo.

Porém, antes de iniciarmos é preciso explicar o tratamento adicional dos dados que foi necessário nesta etapa. Com o objetivo de eliminar possíveis resultados incoerentes, as categorias irrelevantes foram desconsideradas, pois estas alteraram a significância do teste Qui-quadrado e atrapalham a clareza do mapa perceptual. Este processo também foi realizado na tese de Lima (2007).

Assim, nas variáveis de perfil, a categoria Sem emprego (3\% do total) foi eliminada da variável Status profissional; as categorias Outros (3\%) e Alta gestão de grande empresa (2\%) foram eliminadas da variável Nível hierárquico; e, a categoria ONG (2\%) foi eliminada do tipo de organização.

Além disso, eliminamos a categoria extrema (Nunca ou Muito Frequente), caso esta também seja irrelevante (abaixo de 5\%). O quadro abaixo apresenta as variáveis cujas observações em Nunca ou Muito Frequente foram muito pequenas.

\footnotetext{
${ }^{17}$ Pela elevada correlação com a variável Ano de conclusão ( $\mathrm{R}$ de Pearson $=0,918$ ), consideraremos somente a variável Nascimento categorizada pelas faixas: até 30 anos, entre 31 e 40 anos e acima de 40 anos.
} 


\section{Eliminado o Nunca}

Trabalhar em times; Projetos desafiadores;

Mudança de perspectiva; Palestra; Reflexão,

Reflexão sobre comportamento de outro;

Articulação; Livros técnicos e da área;

Feedback; Mecanismos psicológicos
Eliminado o Muito Frequente

Treinamento Hands-on; eLearning; Aula

Particular; Estudo de caso; Simuladores;

Jogos de empresa

Estas variáveis serão seguidas de um asterisco $(*)$ nos quadros que apresentam os resultados dos testes Qui-Quadrado para facilitar a sua distinção.

A questão que originou esta seção da análise fez parte do segundo bloco de questões do instrumento de pesquisa.

\subsubsection{Eventos de Aprendizagem Experiencial}

Foram avaliados sete eventos de Aprendizagem Experiencial, ou seja, aqueles eventos caracterizados por serem informais e não intencionais. No gráfico abaixo, temos um painel que reúne os gráficos de frequência.

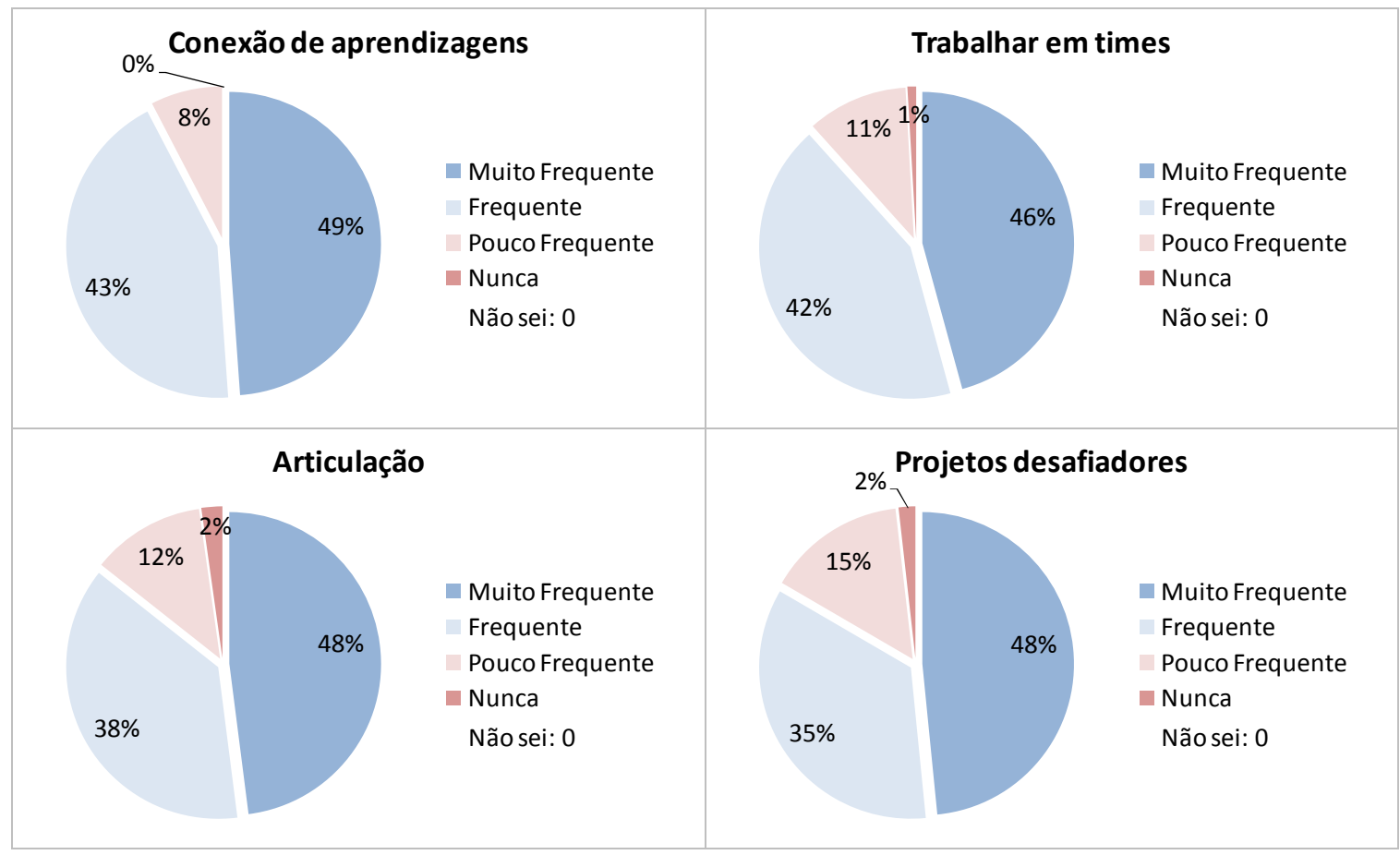




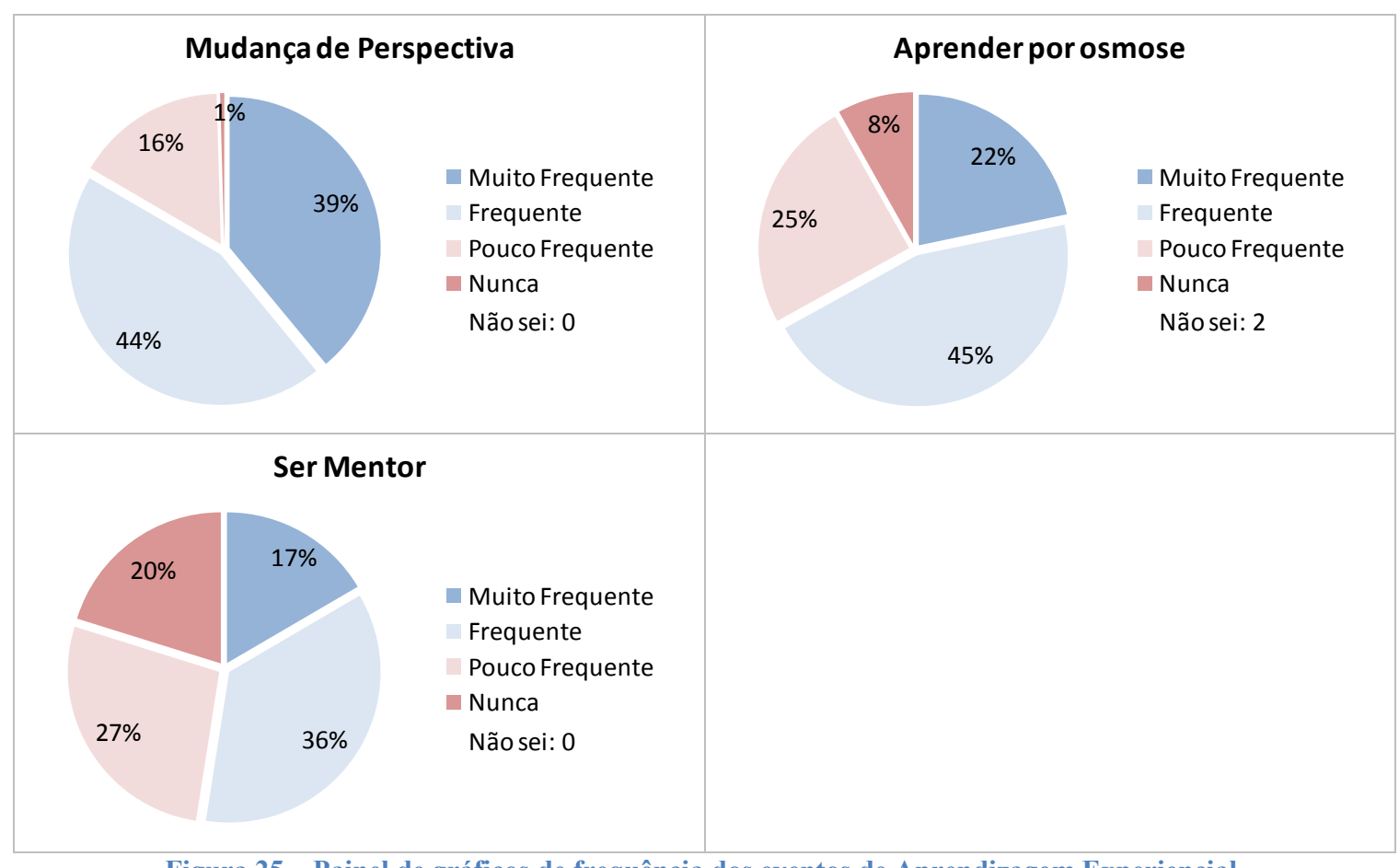

Figura 25 - Painel de gráficos de frequência dos eventos de Aprendizagem Experiencial.

Neste conjunto de gráficos a leitura é facilitada pelas cores: o azul escuro representa o Muito frequente; o azul claro, o Frequente; o vermelho claro, o Pouco frequente; o vermelho escuro, o Nunca. Logo, quanto mais azul, mais frequente é o evento. Como a aprendizagem experiencial obteve a maior avaliação para o desenvolvimento de todas as competências, é natural que seus eventos tenham boa avaliação de frequência.

No evento conexão de aprendizagens, mais de $90 \%$ dos respondentes optaram pela alta frequência, sendo que só em Muito Frequente temos quase metade de todos os respondentes. Nos eventos Trabalhar em times, Articulação, Projetos desafiadores e Mudança de Perspectiva temos frequências bem parecidas, com poucas pessoas respondendo a opção Pouco frequente, e ainda menos a opção de Nunca.

No evento Aprender por osmose ainda mantemos os níveis de frequência elevados. Entretanto, é curioso o pequeno acréscimo das opções de baixa frequência. Pela alta relação com o evento Trabalhar em time, supõe-se que a palavra "osmose" tenha atrapalhado a compreensão da assertiva.

Por fim, ainda com mais da metade de respondentes entre Frequente e Muito Frequente, temos o Ser mentor, evento entre os de aprendizagem experiencial com menor frequência. 
$\mathrm{Na}$ expectativa de encontrar alguma relação entre as variáveis de perfil e de eventos de aprendizagem experiencial, apresentamos na tabela abaixo os resultados dos testes QuiQuadrado.

\begin{tabular}{|c|c|c|c|c|c|c|c|}
\hline & 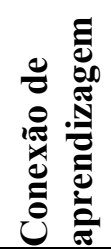 & 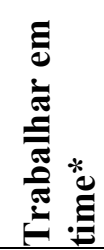 & 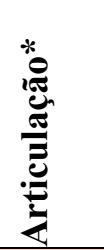 & 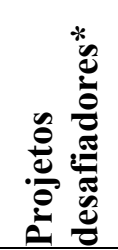 & 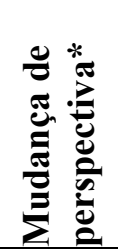 & 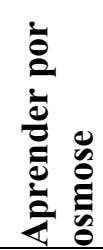 & 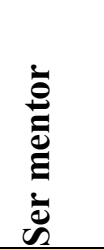 \\
\hline Idade & 0,308 & 0,375 & 0,037 & 0,768 & 0,362 & 0,170 & 0,007 \\
\hline Curso & 0,870 & 0,353 & 0,657 & 0,619 & 0,824 & 0,679 & 0,475 \\
\hline Formação & 0,567 & 0,321 & 0,206 & 0,531 & 0,597 & 0,169 & 0,002 \\
\hline Cursa alguma pós & 0,284 & 0,441 & 0,376 & 0,099 & 0,186 & 0,755 & 0,448 \\
\hline Onde mora & 0,495 & 0,684 & 0,308 & 0,185 & 0,282 & 0,085 & 0,624 \\
\hline Status profissional & 0,308 & 0,974 & 0,590 & 0,219 & 0,038 & 0,737 & 0,052 \\
\hline Nível hierárquico & 0,084 & 0,451 & 0,475 & 0,251 & 0,241 & 0,743 & 0,000 \\
\hline Porte da organização & 0,973 & 0,362 & 0,825 & 0,715 & 0,271 & 0,679 & 0,028 \\
\hline Setor da organização & 0,050 & 0,112 & 0,510 & 0,342 & 0,002 & 0,452 & 0,021 \\
\hline Tipo de organização & 0,375 & 0,028 & 0,256 & 0,010 & 0,298 & 0,206 & 0,469 \\
\hline Tempo na organização & 0,551 & 0,363 & 0,479 & 0,005 & 0,337 & 0,007 & 0,255 \\
\hline
\end{tabular}

Quadro 37 - Resultados dos testes Qui-quadrado para eventos de Aprendizagem Experiencial.

O teste Qui-Quadrado indica relação entre as variáveis quando a significância é menor que 0,05 . As células do quadro acima em vermelho destacam estes valores, os quais serão analisados pelos mapas perceptuais gerados pelo teste ANACOR.

Para estes eventos de aprendizagem experiencial notamos presença maior das variáveis relacionadas à organização. Uma vez que os eventos de aprendizagem experiencial envolvem a prática, o contexto se torna mais relevante.

De certa forma, todos estes eventos apresentaram pelo menos uma relação com as variáveis de perfil. O evento Ser mentor reúne 5 das 13 associações encontradas.

Apresentaremos agora os 13 mapas perceptuais decorrentes de testes ANACOR. Iniciaremos pelos eventos da esquerda do Quadro 37.

A variável Conexão de Aprendizagem apresentou relação estatisticamente significativa com o Setor da organização. Abaixo, apresentamos o mapa perceptual desta relação. 


\section{Symmetrical Normalization}

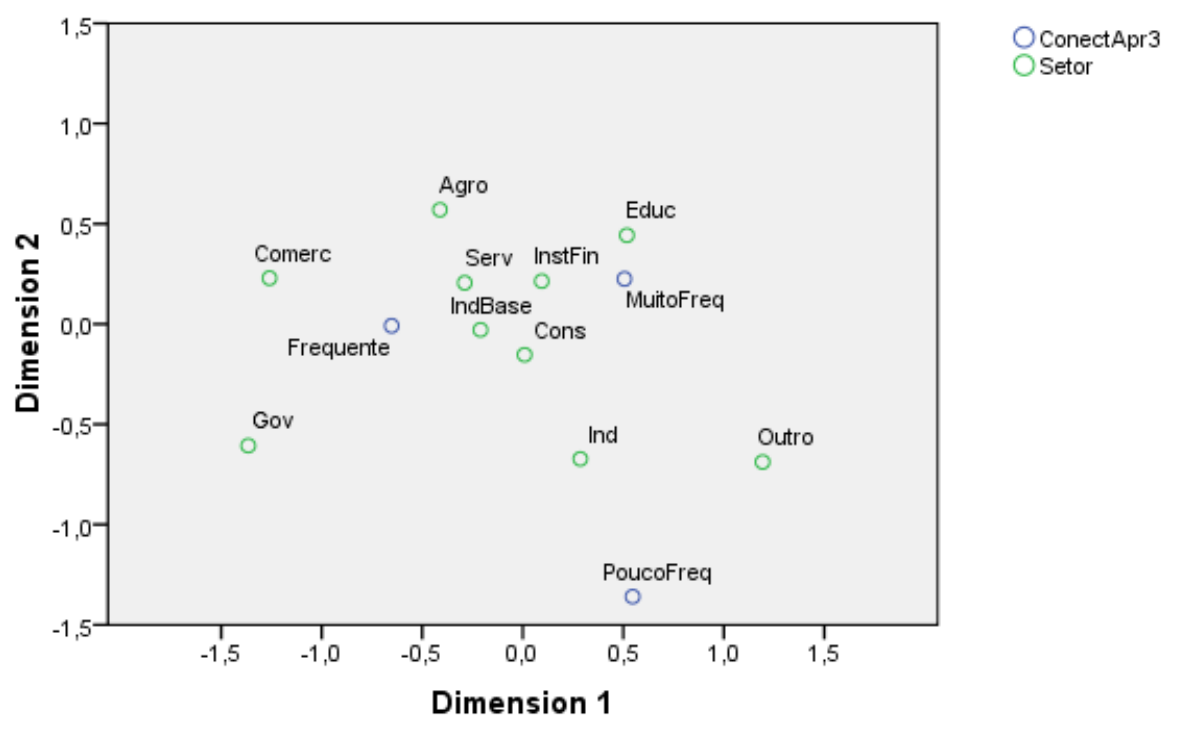

Figura 26 - Mapa das relações entre as categorias de Setor e Conexão de aprendizagem.

Como podemos perceber, este tipo de evento é muito frequente para os setores de Educação e Instituições financeiras, devido a proximidade dos pontos. Para Comércio e Governo é frequente. Para os setores concentrados entre Frequente e Muito Frequente, a distância para Pouco frequente é elevada, logo se distribuem entre as categorias de frequência elevada. A Indústria é o setor eqüidistante aos três níveis de frequência, logo apresenta associação similar com as três. É válido relembrar que este evento não apresentou nenhum Nunca e que Pouco Frequente também foi o menos citado, por isso a sua distância em relação ao centro.

O próximo mapa apresenta relação entre o evento Trabalhar em time e o Tipo de Organização que o indivíduo trabalha. 


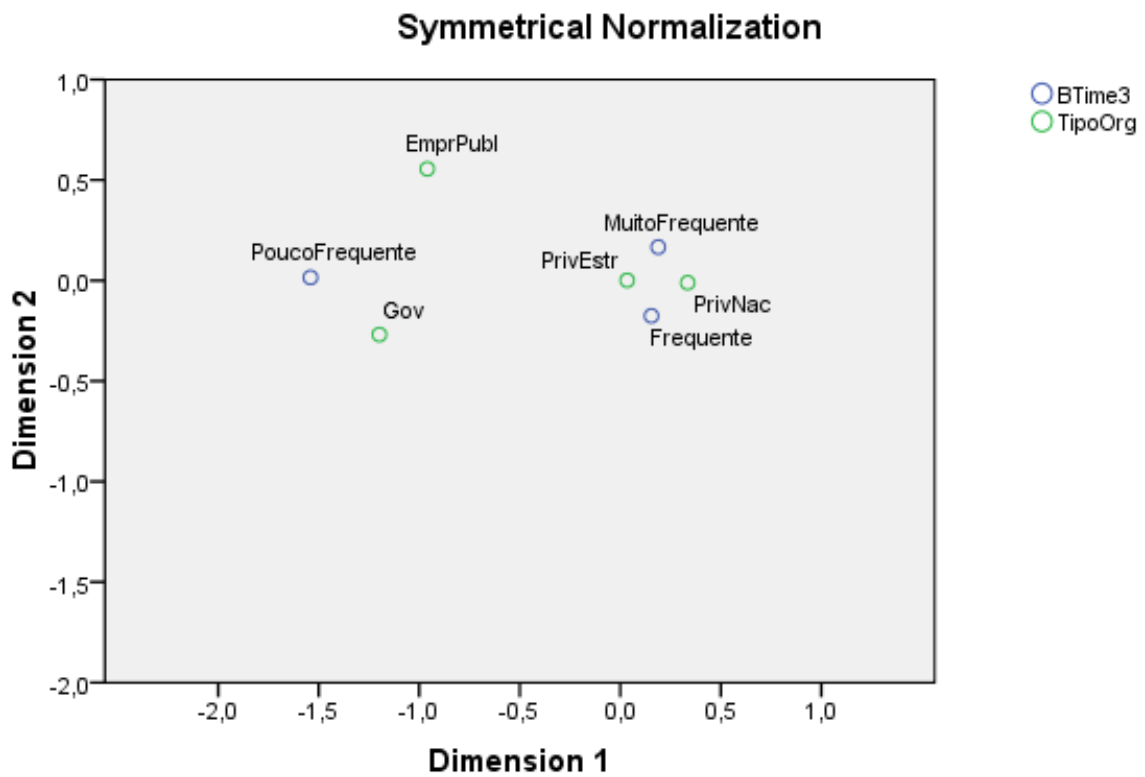

Figura 27 - Mapa das relações entre as categorias de Tipo de organização e Trabalhar em time.

Neste mapa, claramente associamos as empresas privadas às categorias de alta frequência. E, embora com pequena massa $(0,101)$, Pouco Frequente é mais associado ao Governo e à Empresa pública. Logo, podemos dizer que Trabalhar em time é mais comum nas empresas privadas do que no Governo e em Empresas públicas.

O mapa abaixo apresenta a relação entre o evento Articulação e Idade.

Symmetrical Normalization

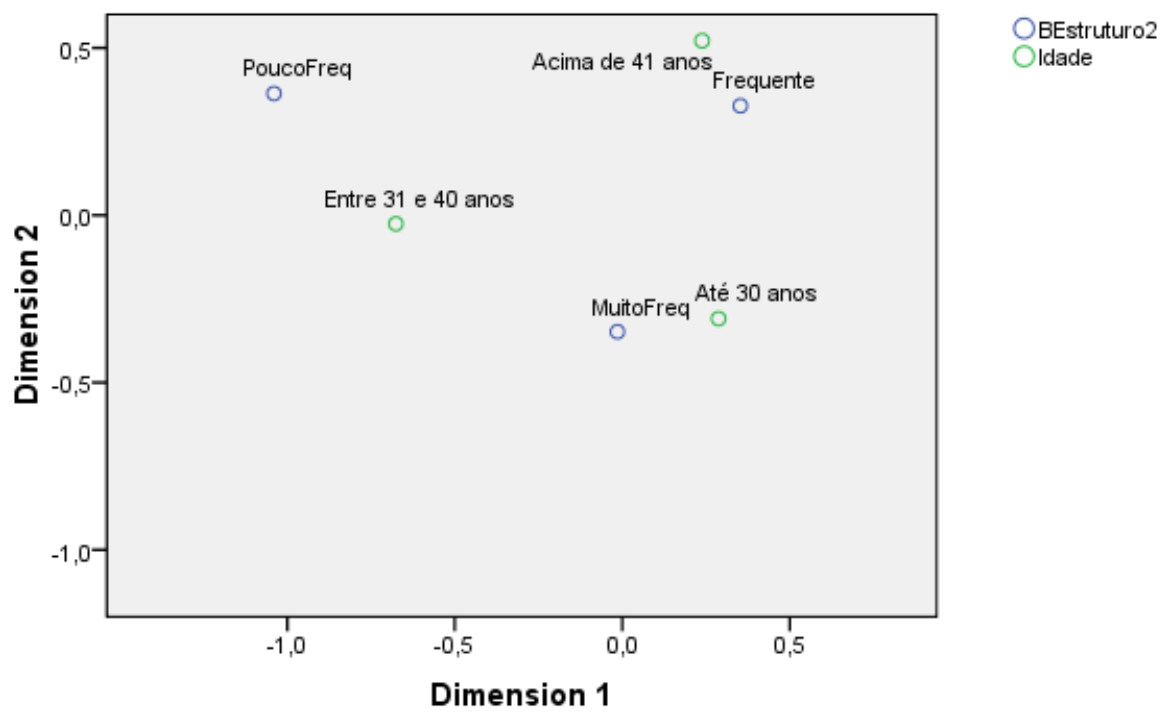

Figura 28 - Mapa das relações entre as categorias de Idade e Articulação.

O evento Articulação é mais associado aos respondentes de até 30 anos, pois estes estão mais próximos ao Muito Frequente. A categoria Acima de 41 anos está relacionada ao Frequente. 
Já para a categoria Entre 31 e 40 anos, não encontramos nenhuma associação nítida, embora esta seja a faixa etária mais próxima de Pouco frequente.

A seguir, o mapa apresenta a relação entre o evento Projeto desafiador e Tipo de organização.

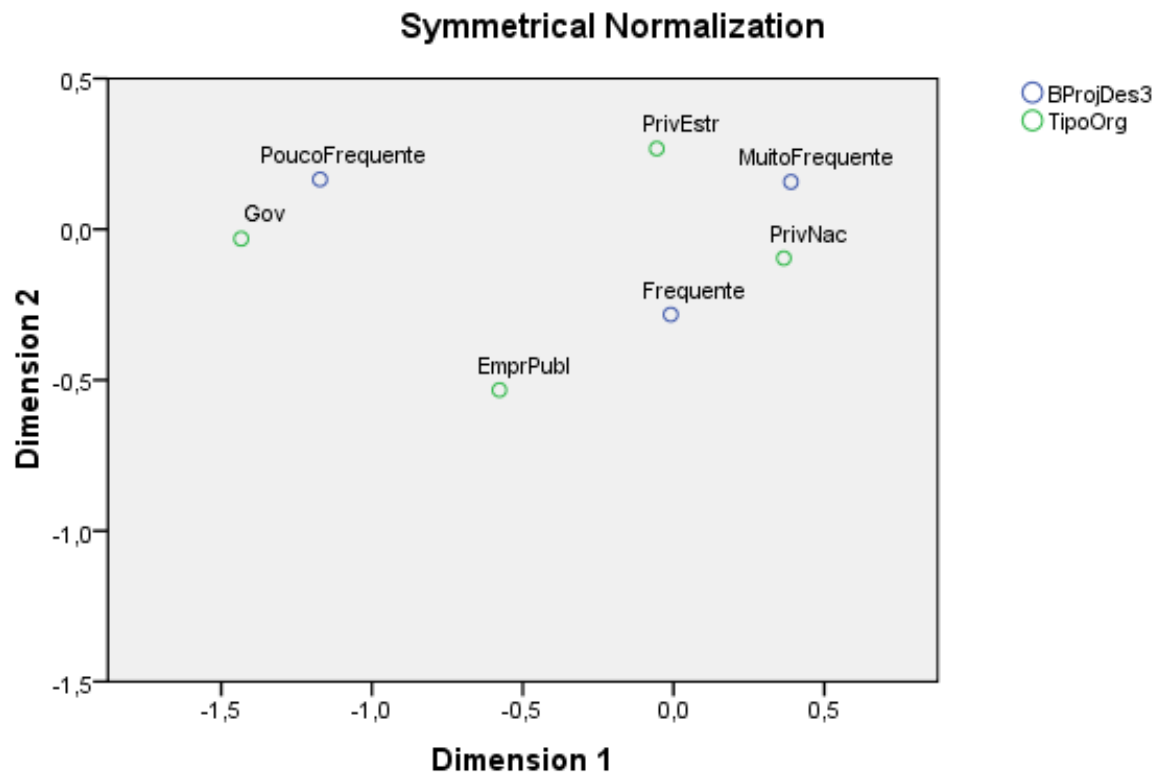

Figura 29 - Mapa das relações entre as categorias de Tipo de organização e Projetos desafiadores.

Novamente identificamos associação maior entre a empresa privada às categorias de alta frequência. Embora a relação entre a Empresa pública não esteja tão clara, para Governo temos relação maior com Pouco frequente.

Abaixo, outro mapa para o evento Projeto desafiador, só que agora com a variável Tempo de organização. 


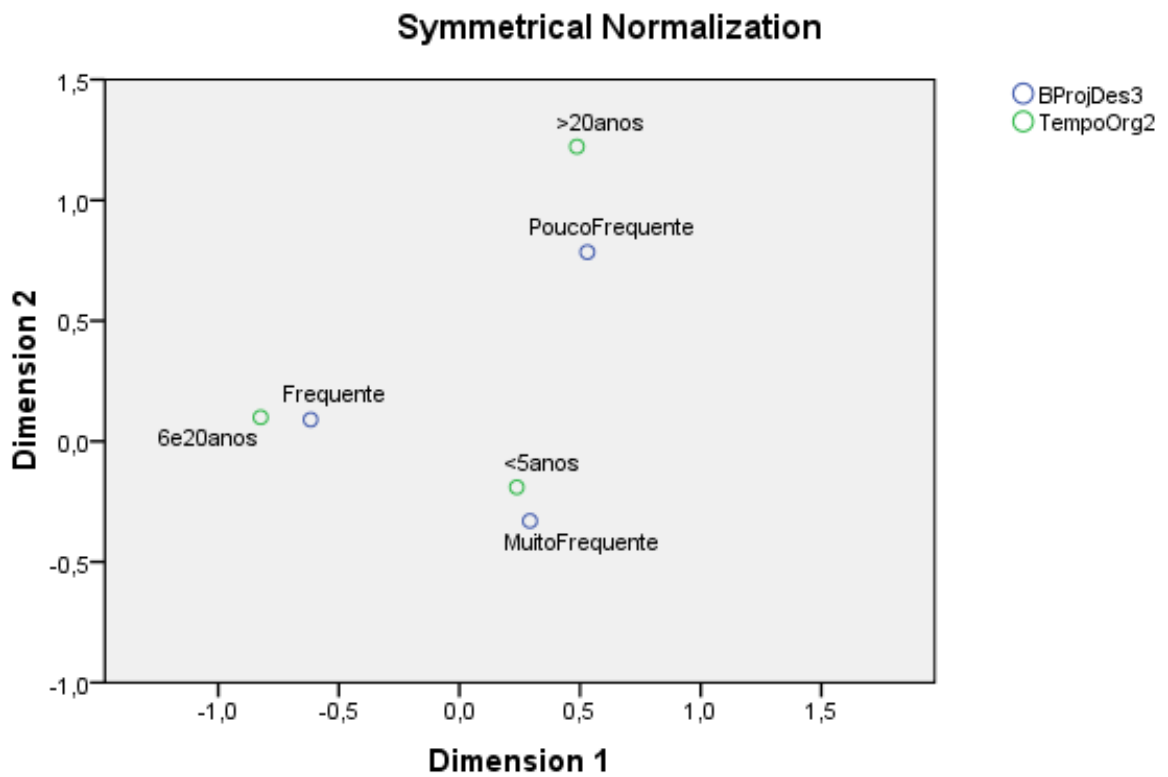

Figura 30 - Mapa das relações entre as categorias de Tempo na organização e Projetos desafiadores.

Notamos clara associação em todas as categorias. E, pelo fato de ambas as variáveis serem ordinais, podemos dizer que quanto maior a faixa de tempo na organização, menor é a frequência de Projetos desafiadores.

O próximo mapa apresenta a relação entre o evento Mudança de perspectiva e Status profissional.

Symmetrical Normalization

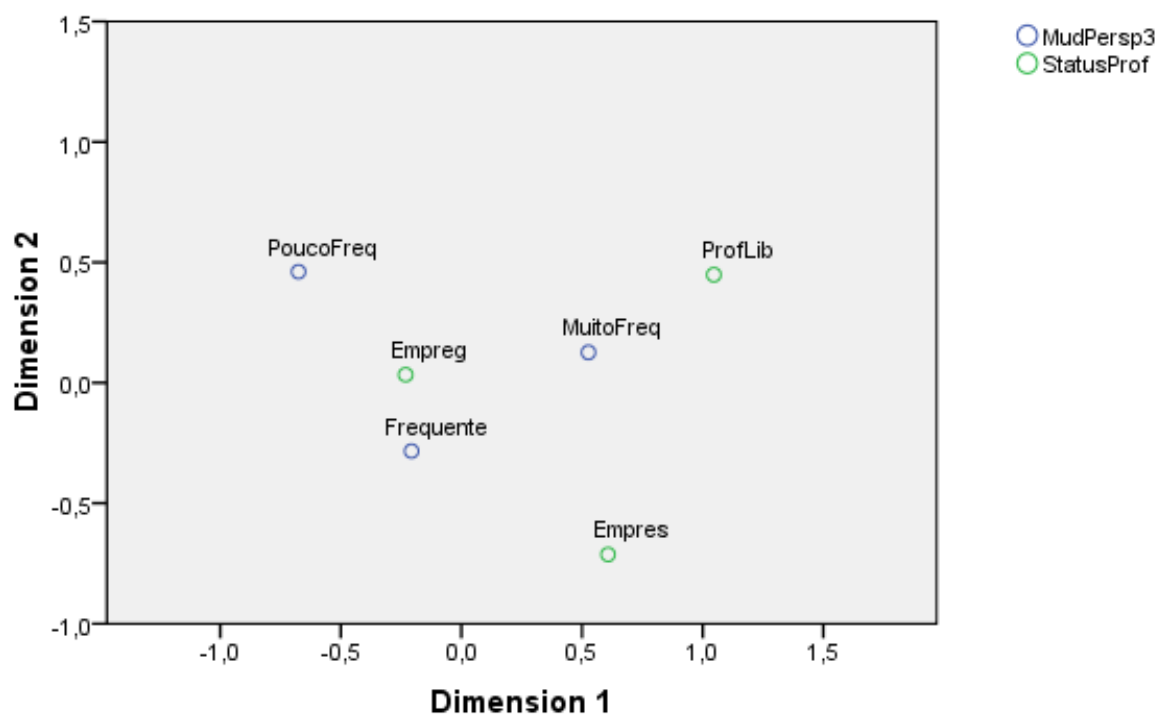

Figura 31 - Mapa das relações entre as categorias de Status profissional e Mudança de perspectiva.

A interpretação deste mapa perceptual nos indica que o Profissional liberal tem uma relação maior com a categoria Muito frequente do que com outras categorias. Já o empresário possui 
a mesma relação com as duas categorias de alta frequência. O Empregado tem relação maior com frequente, embora possa ser associado também com Pouco e Muito Frequente.

Ainda em relação à Mudança de perspectiva, apresentamos sua relação com Setor da organização.

\section{Symmetrical Normalization}

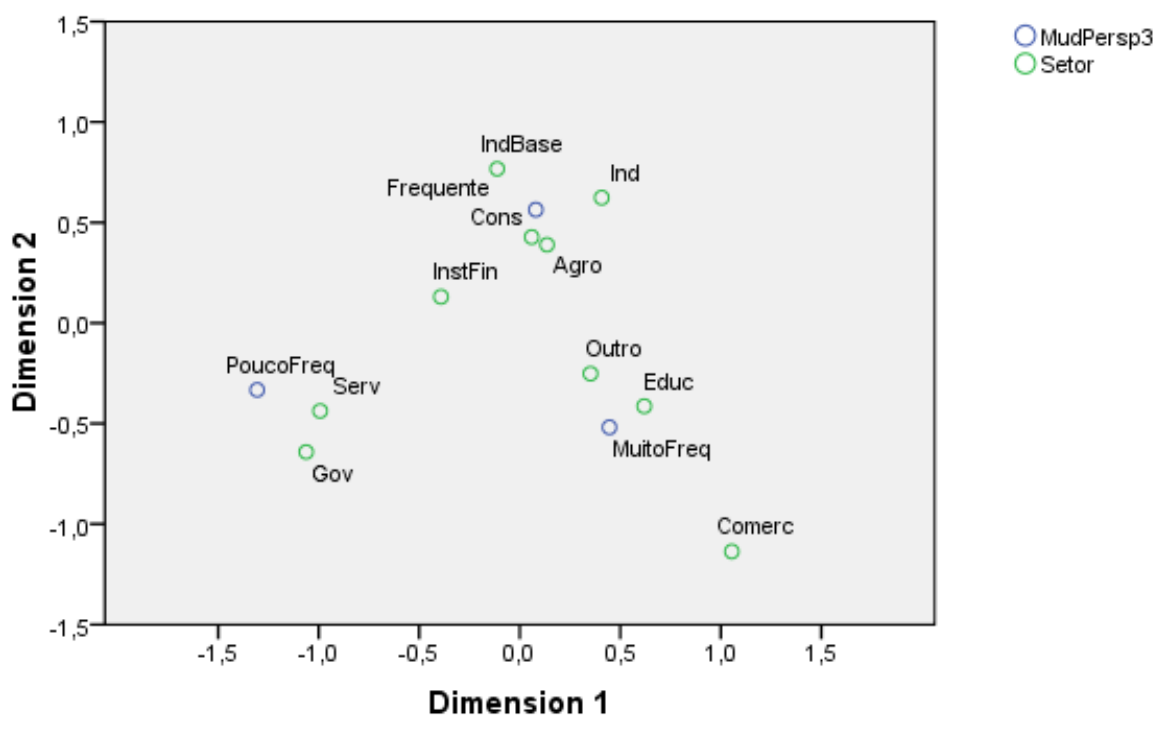

Figura 32 - Mapa das relações entre as categorias de Setor e Mudança de perspectiva.

Notamos um grupo isolado ao lado esquerdo do mapa composto por Governo e Serviços não citados em torno de Pouco frequente. Ao redor de Muito frequente, encontramos Educação, Comércio e Outros setores. E, ao redor de Frequente temos Consultoria, Agronegócio, Indústria, Indústria de base e Instituição financeira.

A relação entre o evento Aprender por osmose e Tempo de organização é apresentada a seguir. 


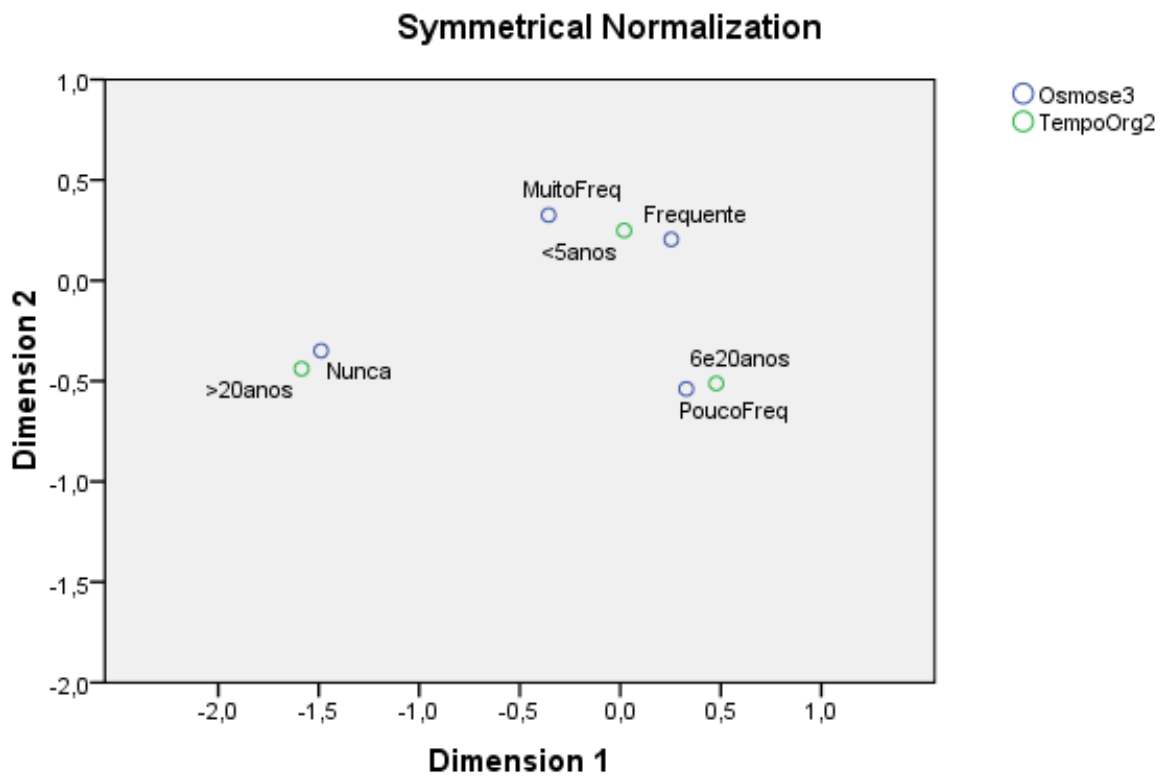

Figura 33 - Mapa das relações entre as categorias de Tempo na organização e Aprender por osmose.

Novamente a variável Tempo de organização apresenta uma nítida relação ordinal com outro evento. Logo é possível dizer que quanto menos tempo de empresa, maior é a frequência de se aprender por osmose. Nunca está associado com que tem mais de 20 anos na organização, enquanto as categorias de alta frequência estão relacionadas com quem tem 5 ou menos anos na organização.

Os cinco próximos mapas perceptuais apresentam relações com o evento Ser mentor. Começaremos por Idade.

\section{Symmetrical Normalization}

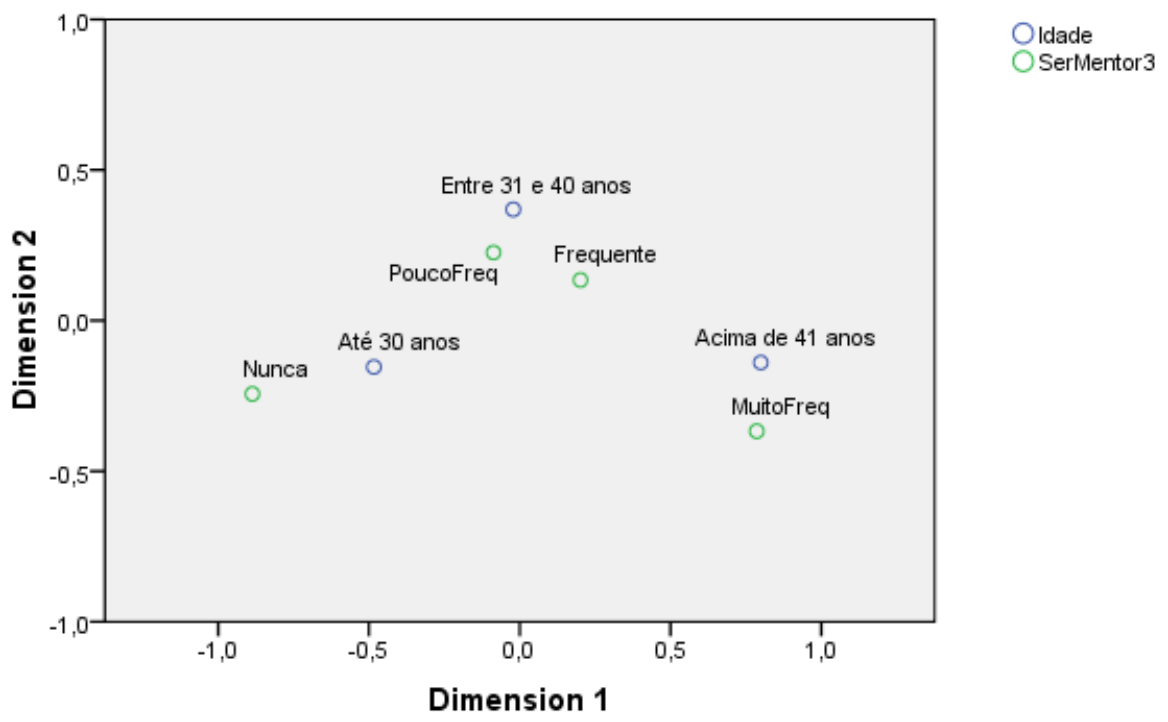

Figura 34 - Mapa das relações entre as categorias de Idade e Ser mentor. 
Podemos dizer que quanto maior a faixa etária, maior será a frequência em relação a Ser mentor. Três grupos nítidos são formados neste mapa: Nunca associa-se com Até 30 anos; Entre 31 e 40 anos associa-se com Pouco frequente e Frequente; e, Muito frequente associa-se com Acima de 41 anos.

\section{Symmetrical Normalization}

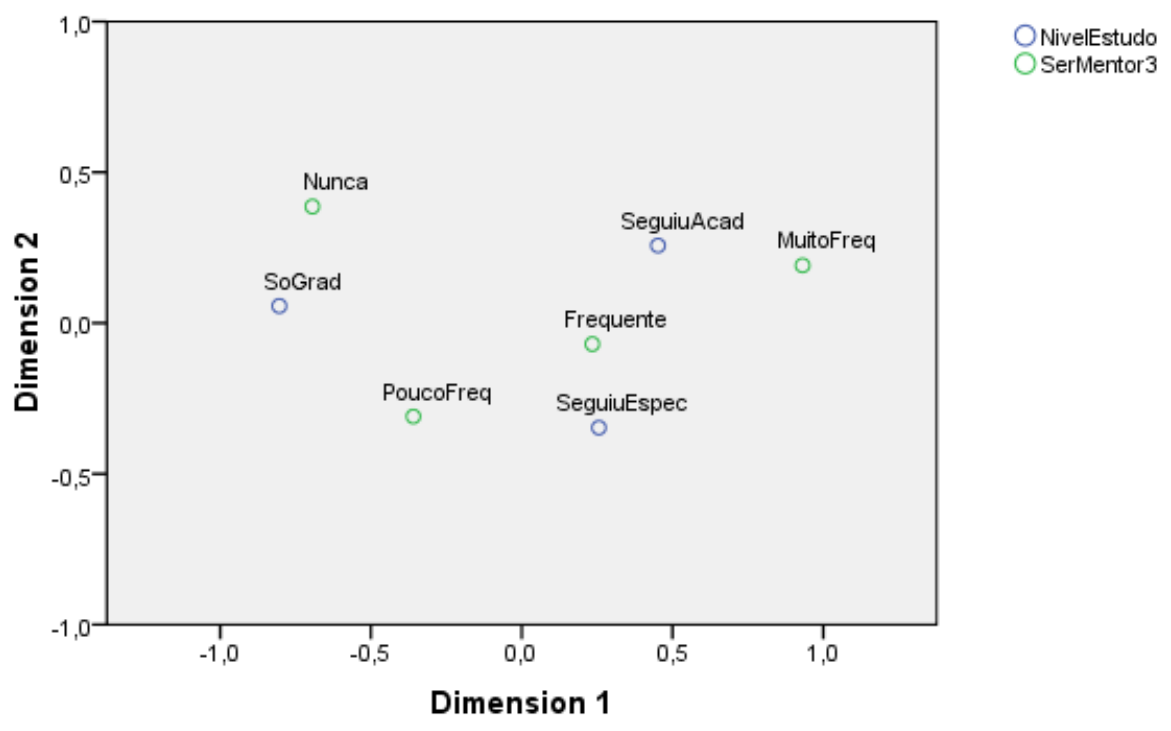

Figura 35 - Mapa das relações entre as categorias de Formação e Ser mentor.

Em relação à Formação, Nunca está próximo de Só graduação, enquanto que Muito frequente está próximo de Seguiu pós acadêmica. Seguiu pós especialização levemente mais associado com Frequente.

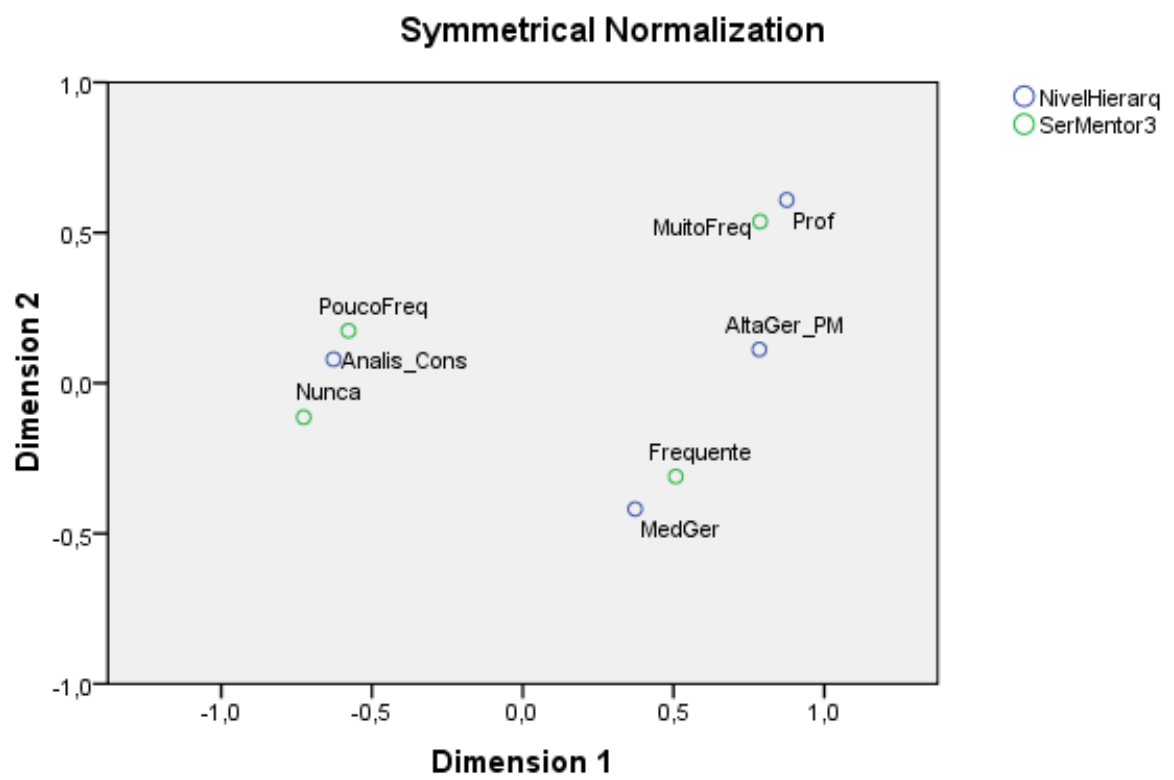

Figura 36 - Mapa das relações entre as categorias de Nível hierárquico e Ser mentor. 
Para o Porte da organização, analisaremos no próximo mapa a relação com a frequência de Ser mentor.

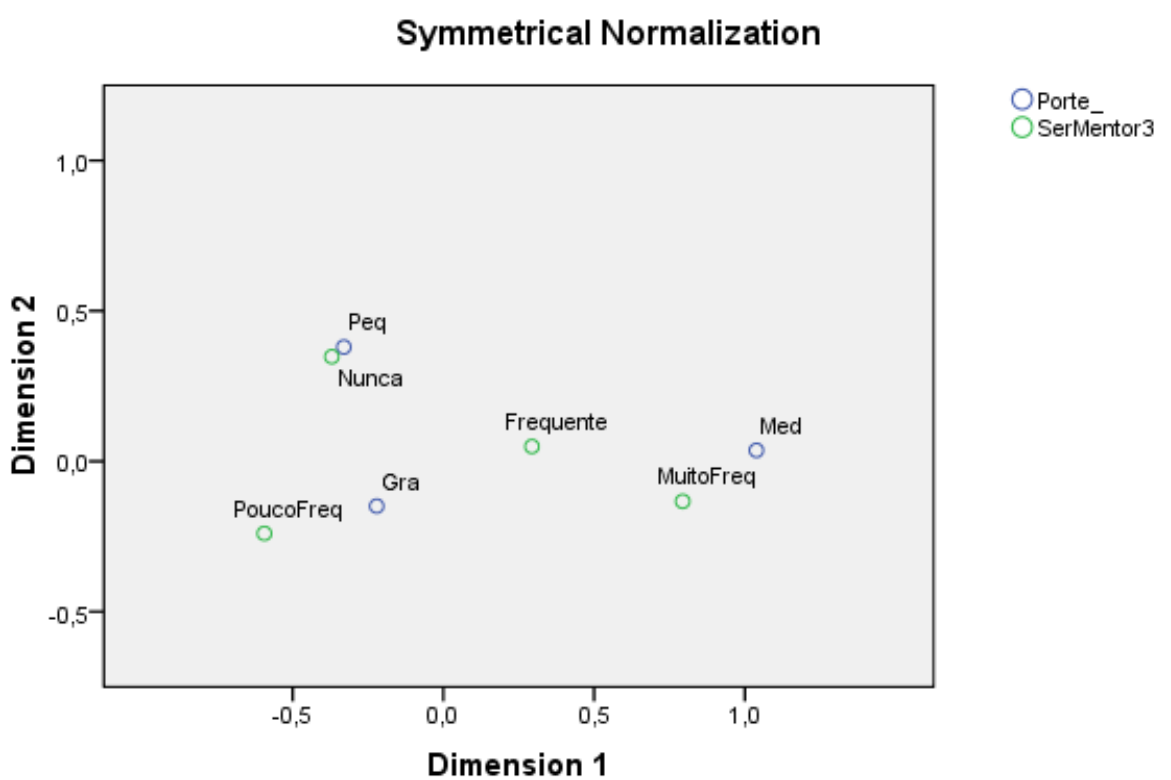

Figura 37 - Mapa das relações entre as categorias de Porte da organização e Ser mentor.

Para quem está em uma organização de Pequeno porte, Nunca está mais próximo. Ao contrário de quem está na Média organização, cuja categoria mais próxima é Muito frequente. Para quem está em uma Grande organização, todas as categorias de frequência são associadas, exceto Muito frequente.

Para nível hierárquico, temos uma relação entre Analistas e consultores e Nunca e Pouco frequente. Professores é a categoria que mais está próxima de Muito Frequente e Média gerência de Frequente. Alta gerência de pequena e média empresa está entre os dois níveis de alta frequência. 


\section{Symmetrical Normalization}

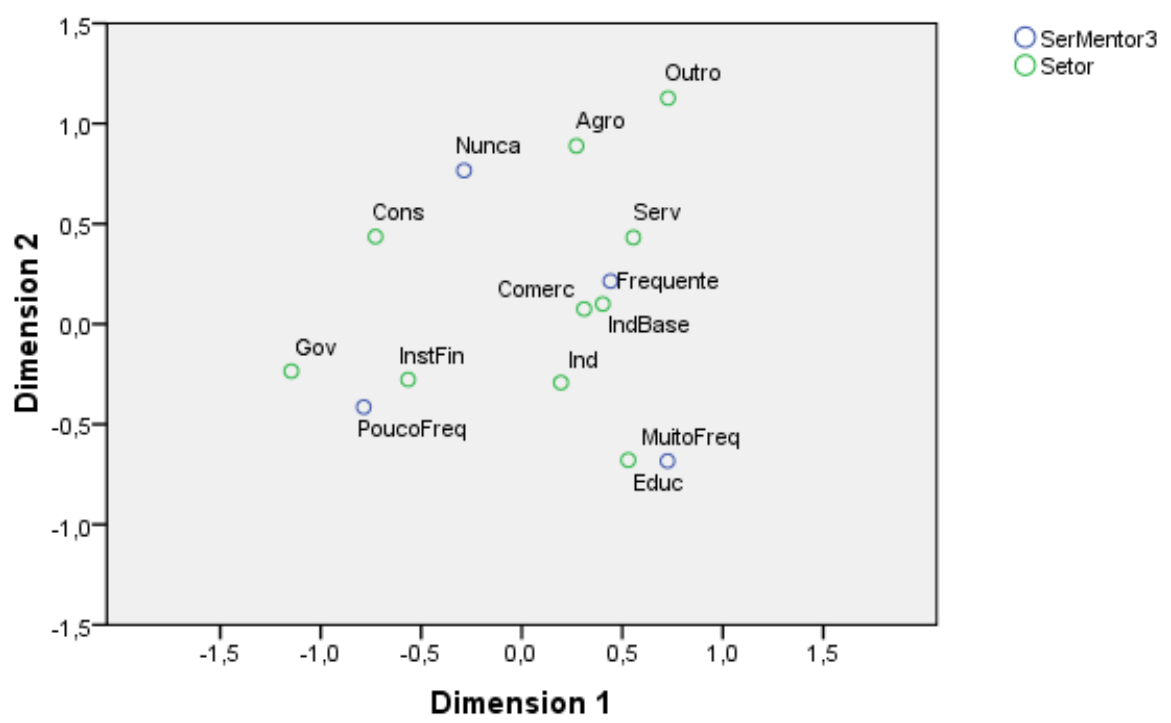

Figura 38 - Mapa das relações entre as categorias de Setor e Ser mentor.

Por fim, temos a relação com Setor da organização. Os três agrupamentos nítidos são: Governo e Instituição financeira com Pouca frequência; Educação para Muito frequente; Indústria de base, Comércio e Serviços não citados com Frequente. Os demais setores encontram-se entre as categorias de frequência de Ser mentor.

\subsubsection{Eventos de Aprendizagem Provocada}

Oito eventos de Aprendizagem Provocada foram avaliados, ou seja, aqueles eventos caracterizados por serem informais e intencionais. No gráfico abaixo, temos um painel que reúne os gráficos de frequência.

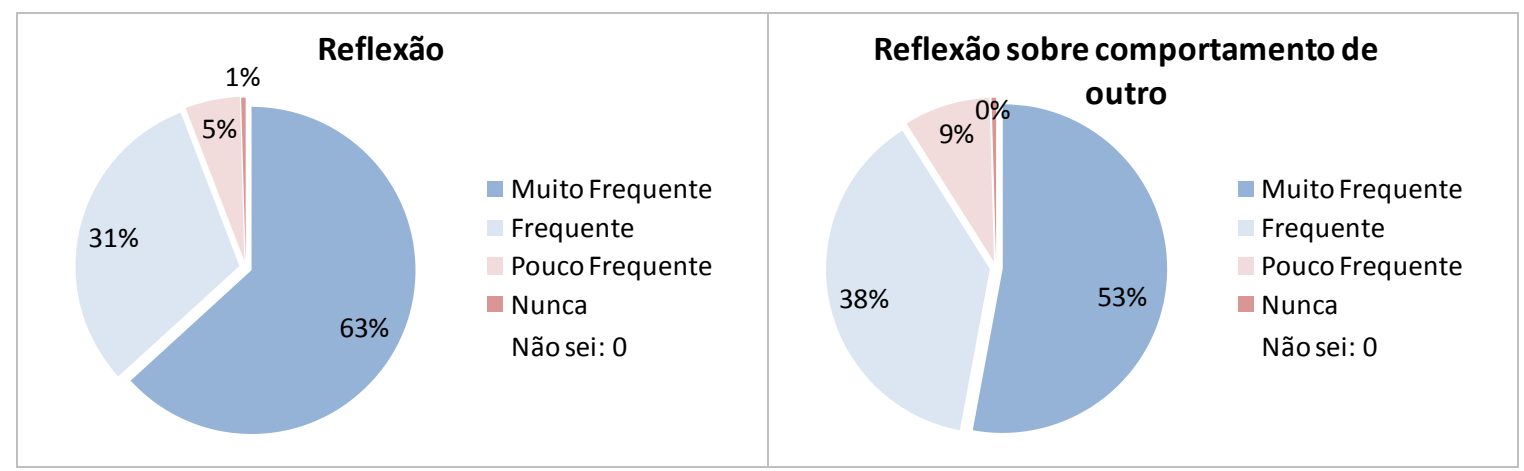




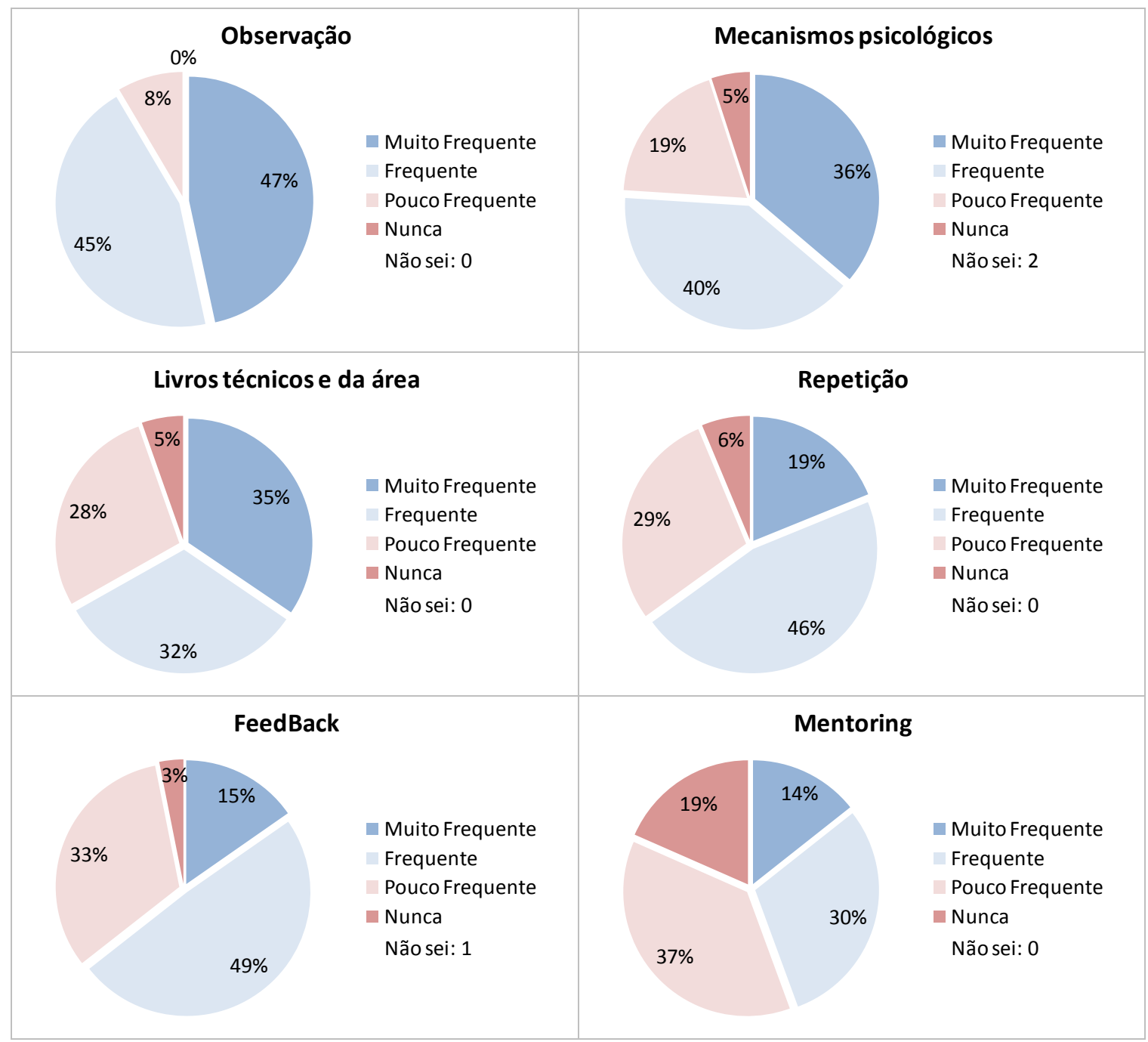

Figura 39 - Painel de gráficos de frequência dos eventos de Aprendizagem Provocada.

A reflexão é um evento permanente na Aprendizagem provocada. Tanto na reflexão própria, quanto na reflexão sobre comportamento de outra pessoa, o somatório entre o Muito frequente e o Frequente ultrapassa 90\%, além disso em ambos só o Muito Frequente ultrapassa metade da distribuição.

A Observação e cópia também desponta entre os eventos mais frequentes com mais de $90 \%$ entre as categorias de alta frequência.

Em Mecanismos psicológicos e Livros técnicos e da área temos Nunca com 5\% em cada e Pouco frequente com $19 \%$ e $28 \%$, respectivamente. Entretanto, em ambos ainda temos um valor considerável para Muito Frequente na faixa dos 35\%. 
Para Prática e repetição e Feedback, temos o somatório de Frequente e Muito frequente em aproximadamente em $65 \%$. A parcela de Pouco frequente já atinge o patamar de $30 \%$. O Mentoring, pos sua vez, foi o único evento deste grupo que apresenta o somatório dos itens de baixa frequência superior aos de alta frequência.

$\mathrm{Na}$ expectativa de encontrar alguma relação entre as variáveis de perfil e de eventos de aprendizagem provocada, apresentamos na tabela abaixo os resultados dos testes de QuiQuadrado.

\begin{tabular}{|c|c|c|c|c|c|c|c|c|}
\hline & 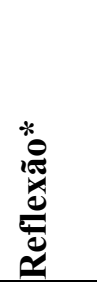 & 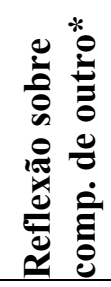 & 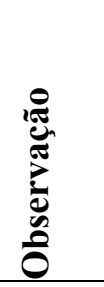 & 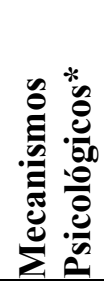 & 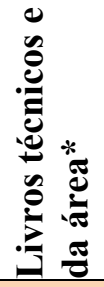 & 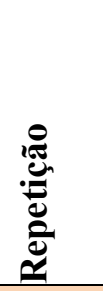 & 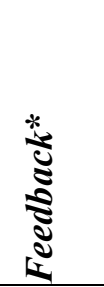 & 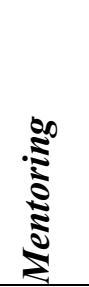 \\
\hline Idade & 0,882 & 0,904 & 0,434 & 0,269 & 0,000 & 0,034 & 0,684 & 0,374 \\
\hline Curso & 0,390 & 0,275 & 0,537 & 0,202 & 0,074 & 0,933 & 0,580 & 0,781 \\
\hline Formação & 0,677 & 0,399 & 0,162 & 0,804 & 0,000 & 0,499 & 0,991 & 0,368 \\
\hline Cursa alguma pós & 0,293 & 0,369 & 0,932 & 0,194 & 0,526 & 0,792 & 0,332 & 0,397 \\
\hline Onde mora & 0,209 & 0,660 & 0,872 & 0,407 & 0,044 & 0,700 & 0,832 & 0,521 \\
\hline Status profissional & 0,255 & 0,285 & 0,902 & 0,013 & 0,024 & 0,770 & 0,176 & 0,365 \\
\hline Nível hierárquico & 0,530 & 0,772 & 0,959 & 0,170 & 0,001 & 0,775 & 0,788 & 0,928 \\
\hline Porte da organização & 0,455 & 0,502 & 0,682 & 0,549 & 0,013 & 0,270 & 0,818 & 0,874 \\
\hline Setor da organização & 0,441 & 0,316 & 0,319 & 0,965 & 0,000 & 0,312 & 0,308 & 0,372 \\
\hline Tipo de organização & 0,376 & 0,735 & 0,605 & 0,671 & 0,088 & 0,561 & 0,565 & 0,918 \\
\hline Tempo na organização & 0,783 & 0,823 & 0,619 & 0,382 & 0,287 & 0,951 & 0,460 & 0,568 \\
\hline
\end{tabular}

Quadro 38 - Resultados dos testes Qui-quadrado para eventos de Aprendizagem Provocada.

O teste Qui-Quadrado indica relação entre as variáveis quando a significância é menor que 0,05 . As células do quadro acima em vermelho destacam estes valores, os quais serão analisados pelos mapas perceptuais gerados pelo teste ANACOR.

Quase todas as relações encontradas pertencem ao evento Leitura técnica ( 7 de 9). Tirando esta exceção, no geral poucos eventos foram associados com as variáveis de perfil.

Iniciaremos com a relação entre o evento Mecanismos psicológicos e Status profissional. 


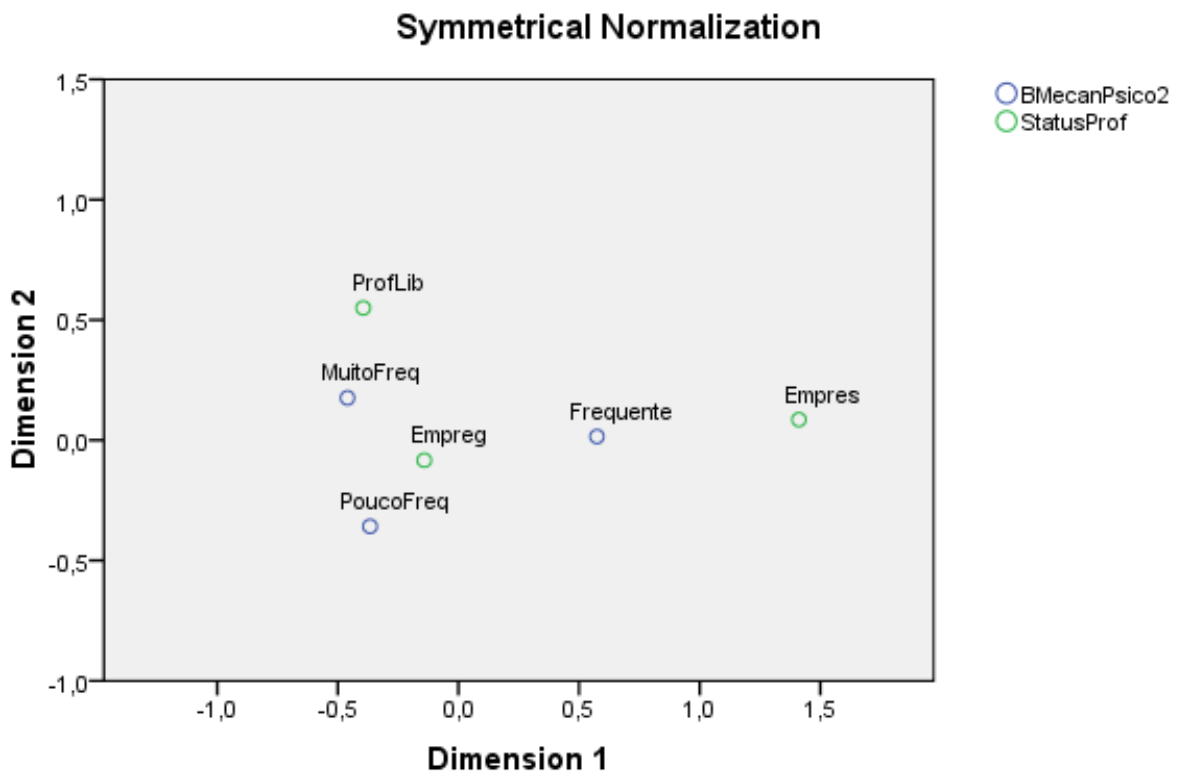

Figura 40 - Mapa das relações entre as categorias de Status profissional e Mecanismos psicológicos.

O mapa acima mostra relação entre Empresário e Frequente, e Profissional liberal e Muito frequente. Para Empregado, temos quase a mesma distância para as três categorias de frequência.

Abaixo, apresentaremos os 5 mapas perceptuais do evento Leitura técnica.

\section{Symmetrical Normalization}

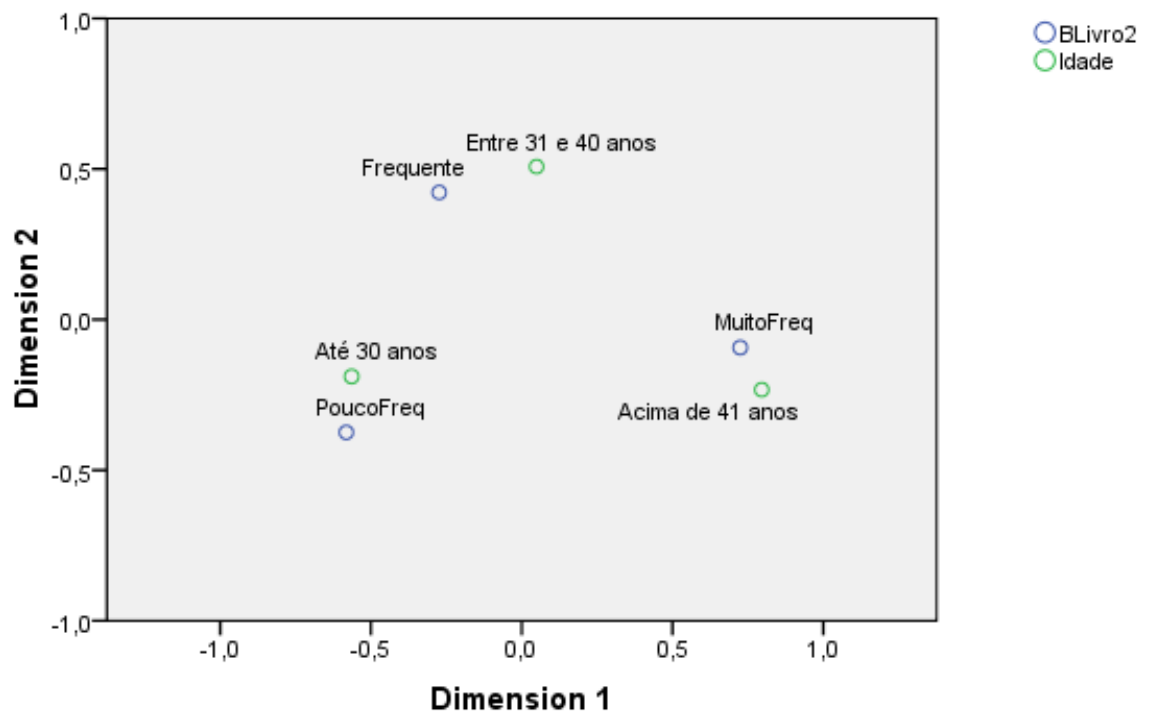

Figura 41 - Mapa das relações entre as categorias de Idade e Livros técnicos e da área.

A primeira leitura indica que quanto maior a faixa etária, maior é a frequência do evento Leitura técnica. A relação é nítida entre os pares de categorias: Pouco frequente e Até 30 anos; Frequente e Entre 31 anos e 40 anos; e, Muito frequente e Acima de 41 anos. 


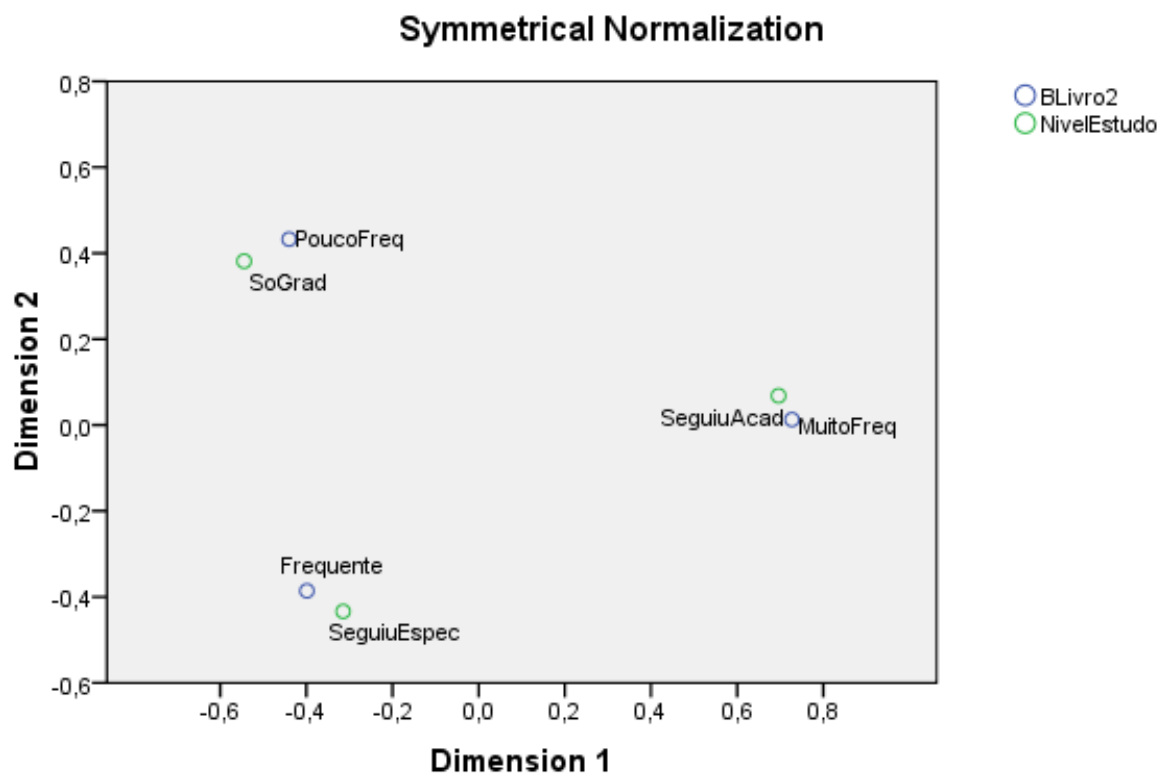

Figura 42 - Mapa das relações entre as categorias de Formação e Livros técnicos e da área.

Mais intensa ainda é a relação entre Leitura técnica e Formação. É Muito frequente para aqueles quem seguiram trajetória acadêmica; Frequente para quem seguiu uma pós especialização; e, Pouco frequente para quem parou só com a graduação.

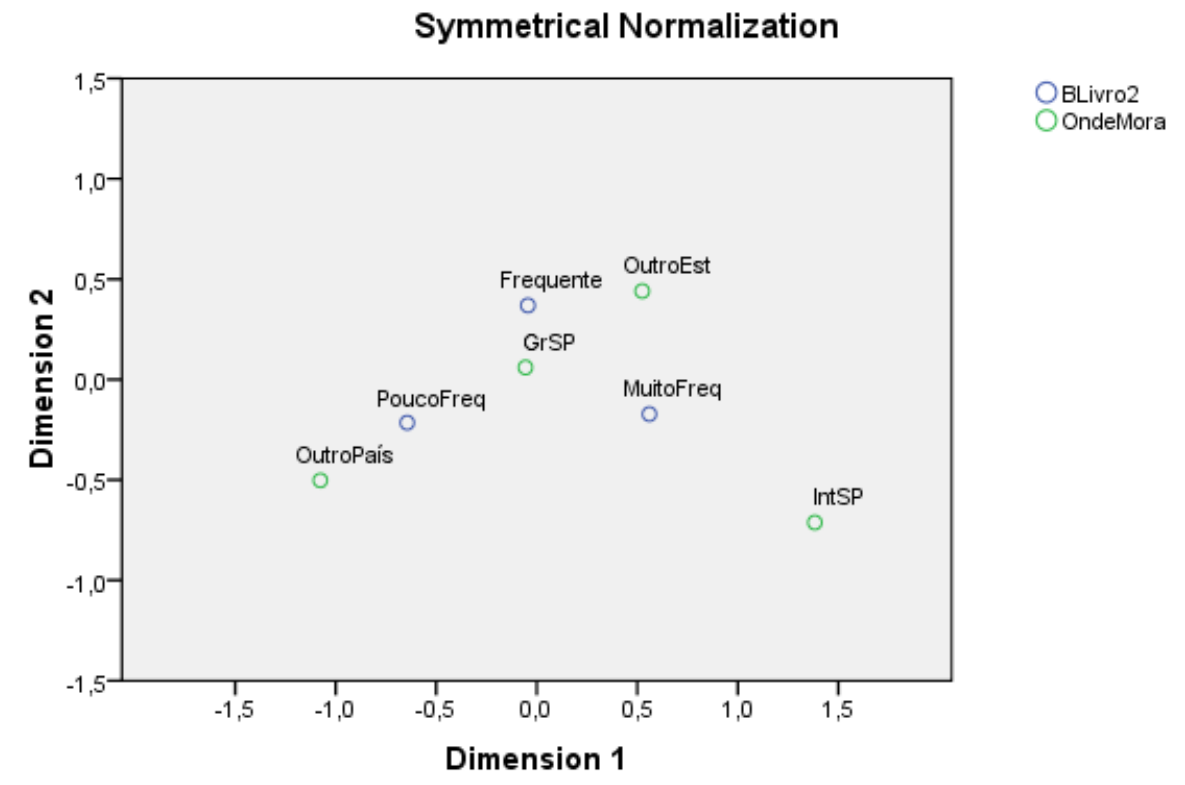

Figura 43 - Mapa das relações entre as categorias de Onde mora e Livros técnicos e da área.

Embora as associações deste último mapa não estejam tão claras com a anterior, é possível identificar relação entre as categorias Outro país e Pouco frequente, e Interior de São Paulo e Muito frequente. Outro estado está entre as duas categorias de alta frequência. Grande São Paulo apresenta a maior massa $(0,773)$, por isso está quase no centro do mapa. Esta categoria se associa primeiramente com Frequente, seguido por Muito frequente e Pouco frequente. 


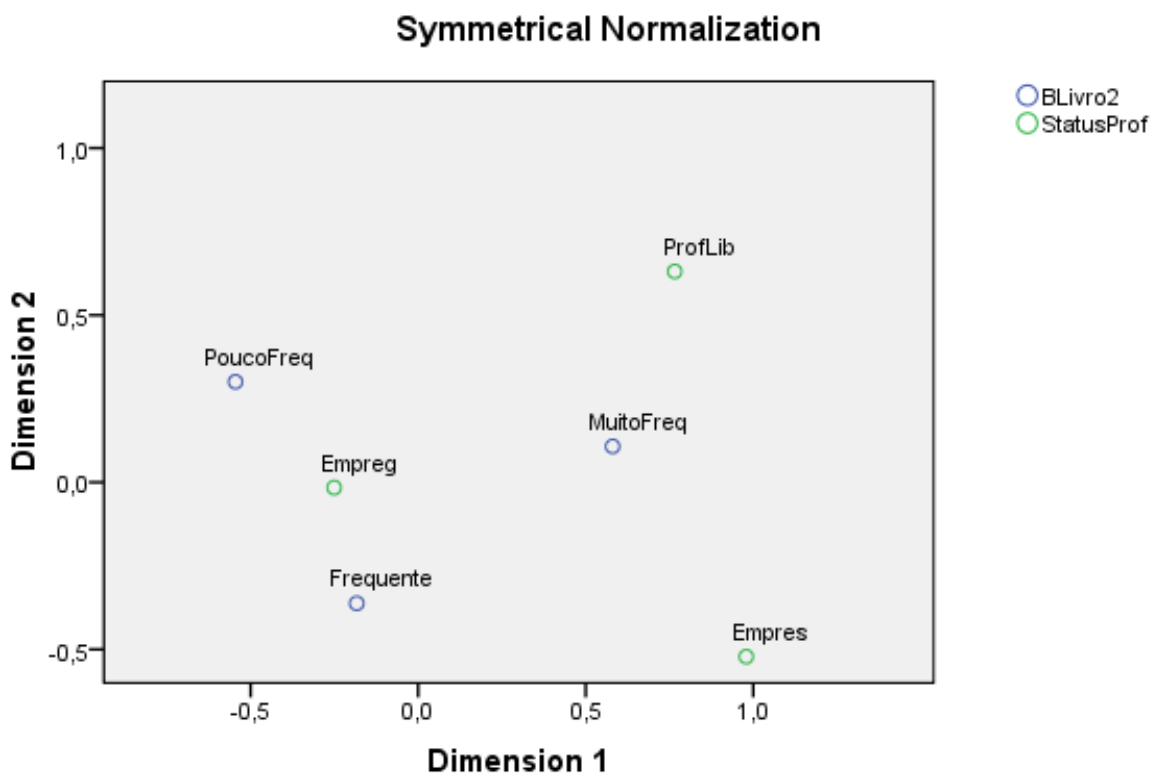

Figura 44 - Mapa das relações entre as categorias de Status profissional e Livros técnicos e da área.

Para Status profissional, quem é Profissional liberal ou Empresário está mais próximo de Muito frequente, enquanto que para quem é Empregado, a Leitura técnica está mais para Pouco frequente e para Frequente do que para Muito frequente.

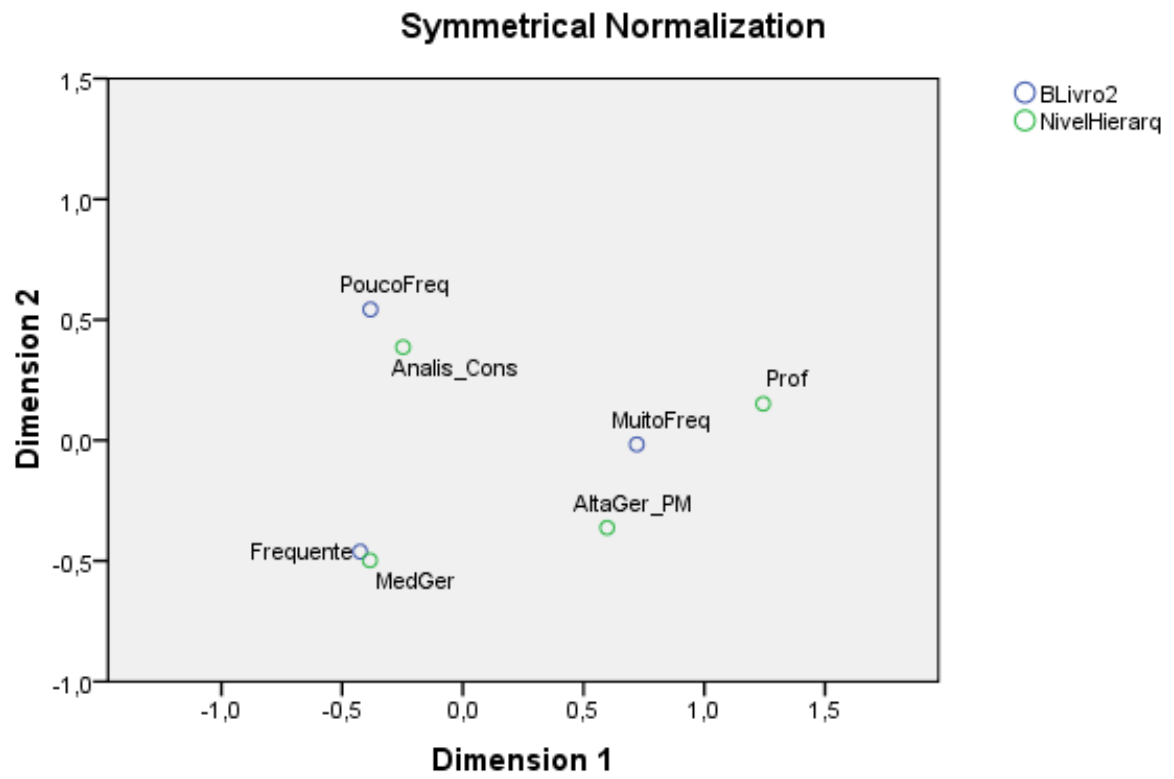

Figura 45 - Mapa das relações entre as categorias de Nível hierárquico e Livros técnicos e da área.

No mapa acima temos 3 grupos formados. Analista e consultor está mais associado com Pouco frequente; Média gerência está associada com Frequente; e, Muito frequente está relacionado com Professor e Alta gerência de pequena e média empresa. 


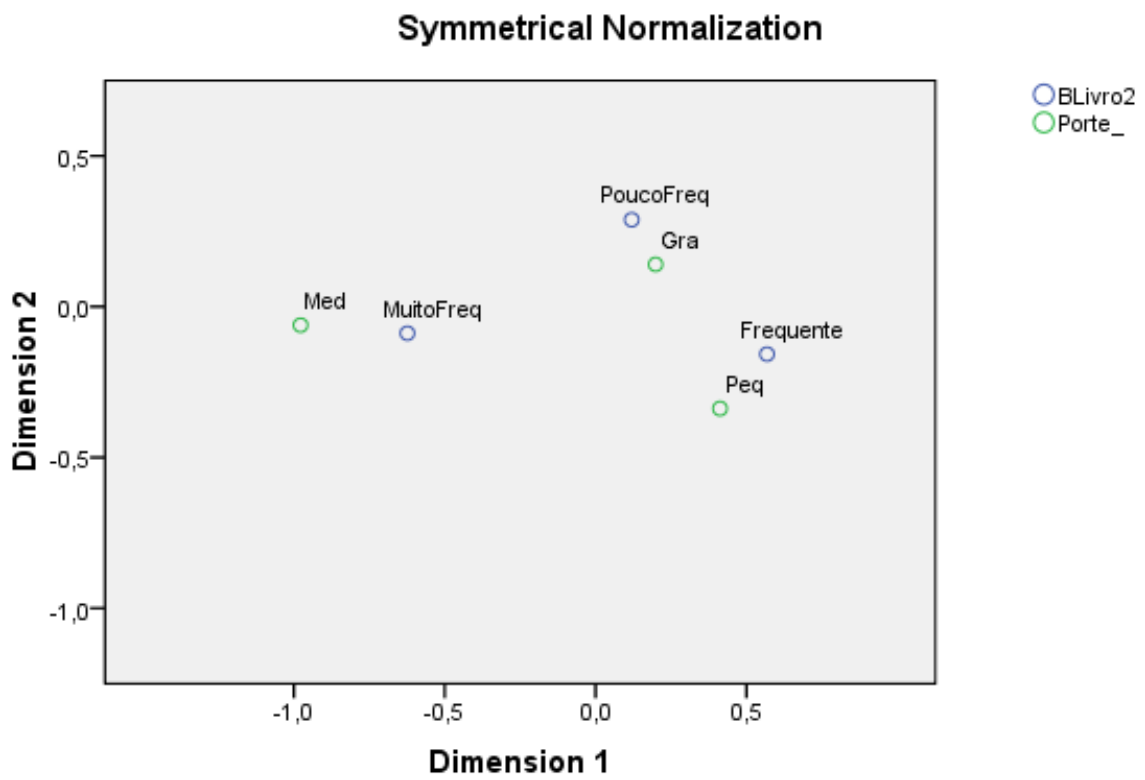

Figura 46 - Mapa das relações entre as categorias de Porte da organização e Livros técnicos e da área.

Para Porte da organização, a Leitura técnica é menos frequente para a Grande organização, enquanto que para a Média empresa esta é Muito frequente. Para Pequena organização, a relação é maior com Frequente.

\section{Symmetrical Normalization}

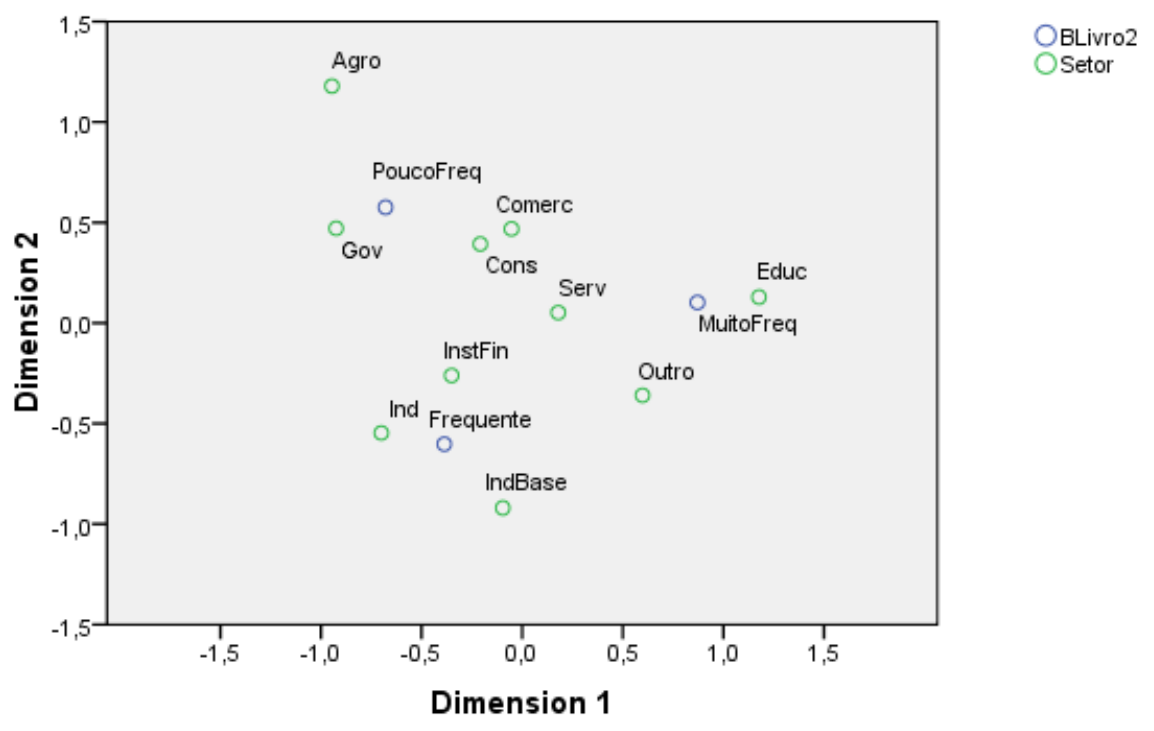

Figura 47 - Mapa das relações entre as categorias de Setor e Livros técnicos e da área.

Para Setores da organização, a Leitura técnica é Muito frequente para Educação; Frequente para Indústria, Indústria de base e Instituição financeira. Pouco frequente para Agronegócio e Governo. Para os demais setores, a associação ocorre com mais de uma categoria de frequência. 


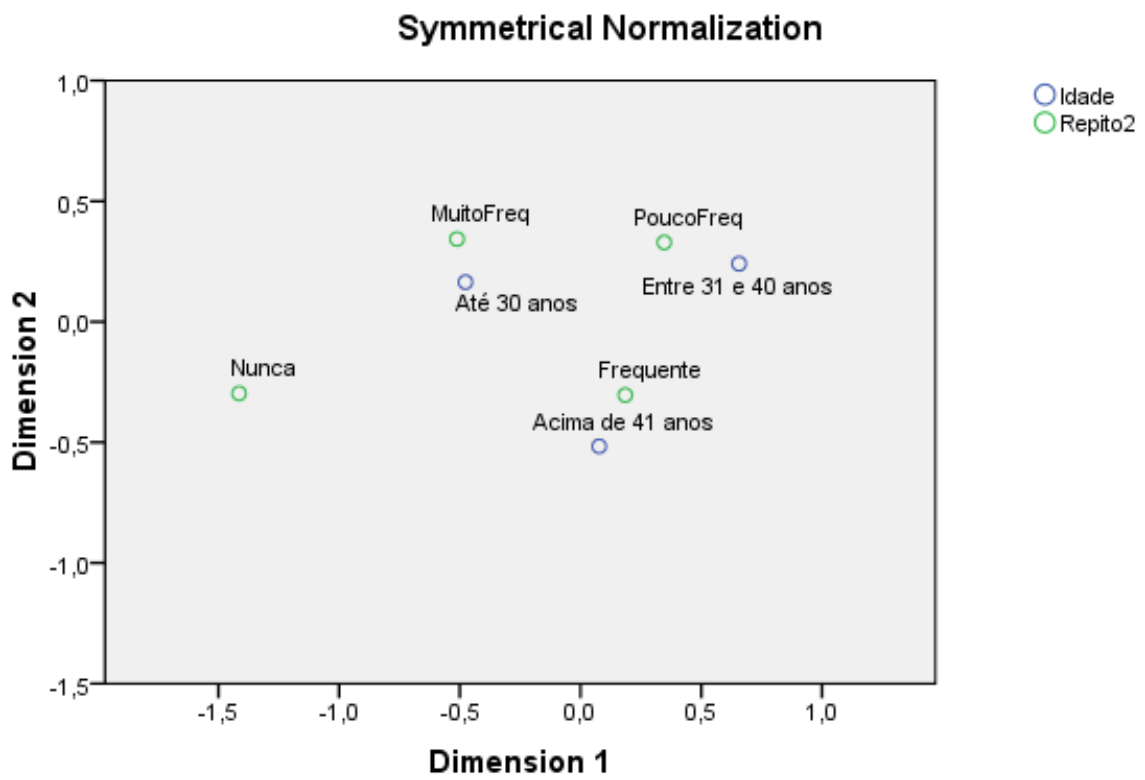

Figura 48 - Mapa das relações entre as categorias de Idade e Repetição.

O último mapa perceptual é para a relação entre o evento Repetição e Idade. A categoria Entre 31 e 40 anos tem mais relação com Pouco frequente, enquanto que Acima de 41 anos possui mais relação com Frequente. Até 30 anos relaciona-se mais com a categoria Muito Frequente.

\subsubsection{Eventos de Aprendizagem Conceitual}

Cinco eventos de Aprendizagem Conceitual foram avaliados. Estes eventos são caracterizados por serem formais e intencionais. No gráfico abaixo, temos um painel que reúne os gráficos de frequência.

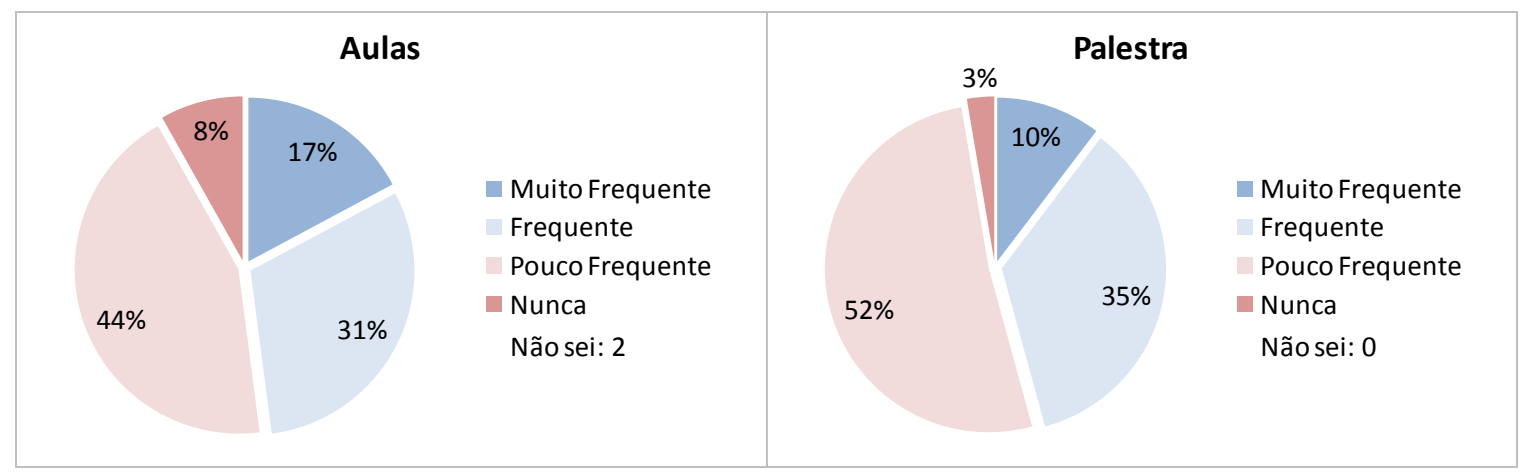




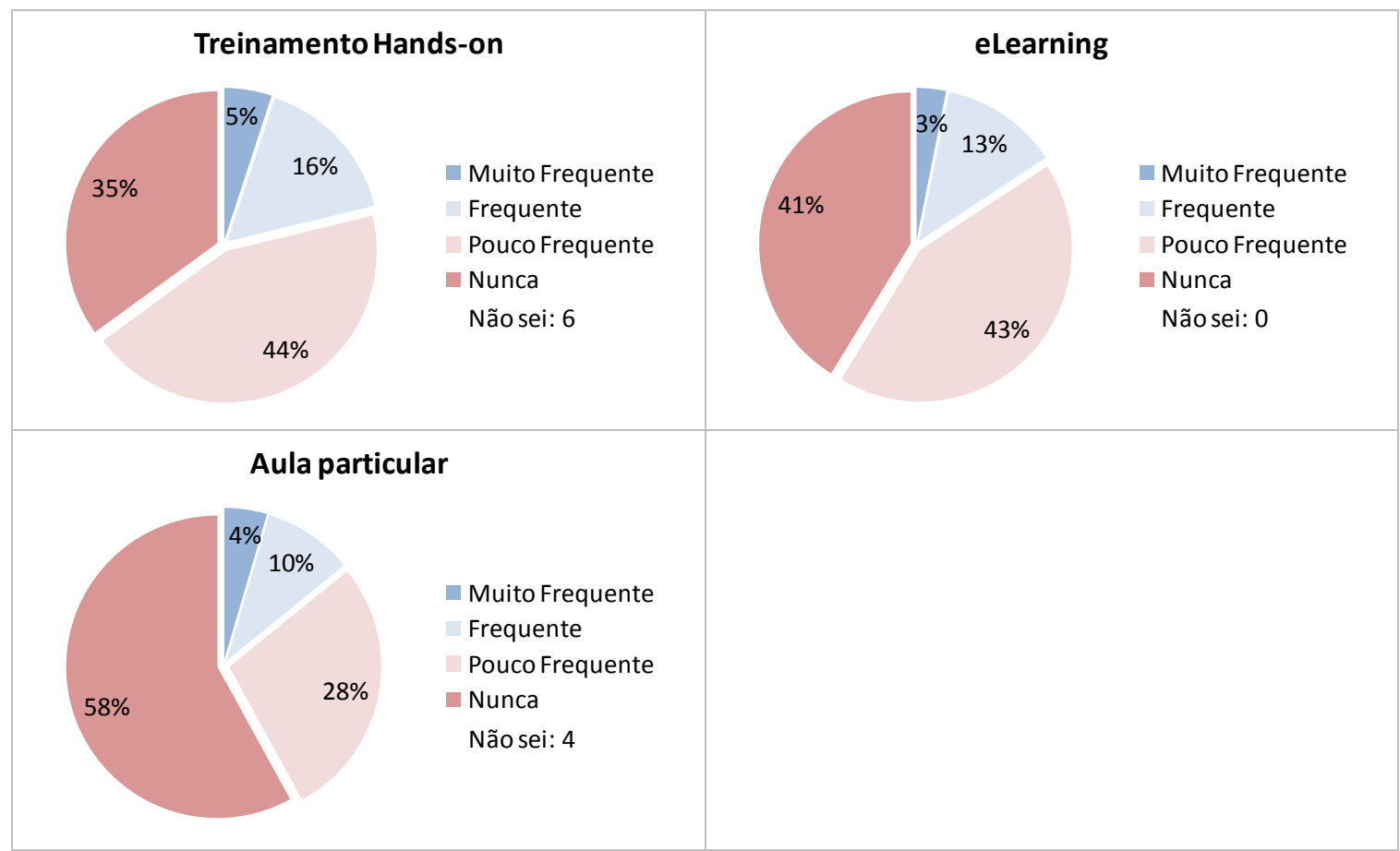

Figura 49 - Painel de gráficos de frequência dos eventos de Aprendizagem Conceitual.

Notamos em Aula um equilíbrio da distribuição das frequências, que se encontra metade para as de baixa frequência e a outra para as de alta.

Em Palestra, a parcela do Pouco Frequente por si só já ultrapassa os 50\%. E, em Treinamento hands-on, eLearning e Aula particular já notamos a baixa frequência, por conta das pequenas fatias atribuídas a Muito Frequente e Frequente. Em Aula particular, por exemplo, só 14\% é a junção entre as categorias Muito Frequente e Frequente.

$\mathrm{Na}$ expectativa de encontrar alguma relação entre as variáveis de perfil e de eventos de aprendizagem conceitual, apresentamos na tabela abaixo os resultados dos testes de QuiQuadrado.

\begin{tabular}{|c|c|c|c|c|c|}
\hline & $\frac{\pi}{\Xi}$ & 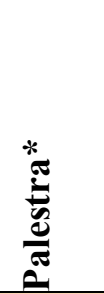 & 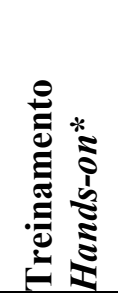 & 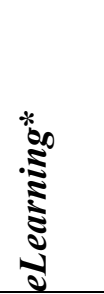 & 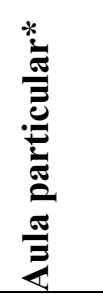 \\
\hline Idade & 0,197 & 0,001 & 0,184 & 0,060 & 0,051 \\
\hline Curso & 0,365 & 0,115 & 0,519 & 0,128 & 0,015 \\
\hline Formação & 0,000 & 0,050 & 0,149 & 0,489 & 0,834 \\
\hline Cursa alguma pós & 0,003 & 0,003 & 0,079 & 0,260 & 0,749 \\
\hline Onde mora & 0,682 & 0,231 & 0,836 & 0,413 & 0,192 \\
\hline
\end{tabular}




\begin{tabular}{|l|l|l|l|l|l|}
\hline Status profissional & 0,123 & 0,413 & 0,682 & 0,336 & 0,467 \\
\hline Nível hierárquico & 0,021 & 0,017 & 0,497 & 0,918 & 0,590 \\
\hline Porte da organização & 0,142 & 0,090 & 0,069 & 0,354 & 0,899 \\
\hline Setor da organização & 0,824 & 0,022 & 0,096 & 0,971 & 0,563 \\
\hline Tipo de organização & 0,054 & 0,005 & 0,322 & 0,187 & 0,916 \\
\hline Tempo na organização & 0,371 & 0,087 & 0,252 & 0,099 & 0,021 \\
\hline
\end{tabular}

Quadro 39 - Resultados dos testes Qui-quadrado para eventos de Aprendizagem Conceitual.

As relações estatisticamente significantes entre as variáveis são apresentadas em vermelho no quadro anterior. Enquanto que dois eventos de aprendizagem (Treinamento hands-on e eLearning) não acusaram relação alguma, Palestra apresentou 6 das 11 relações identificadas. É válido lembrar que não foi possível gerar os mapas perceptuais da variável Cursa alguma pós, pois só há duas categorias, sendo que o necessário é de no mínimo três.

Começaremos com a leitura do mapa da associação entre o evento Aula e Formação.

\section{Symmetrical Normalization}

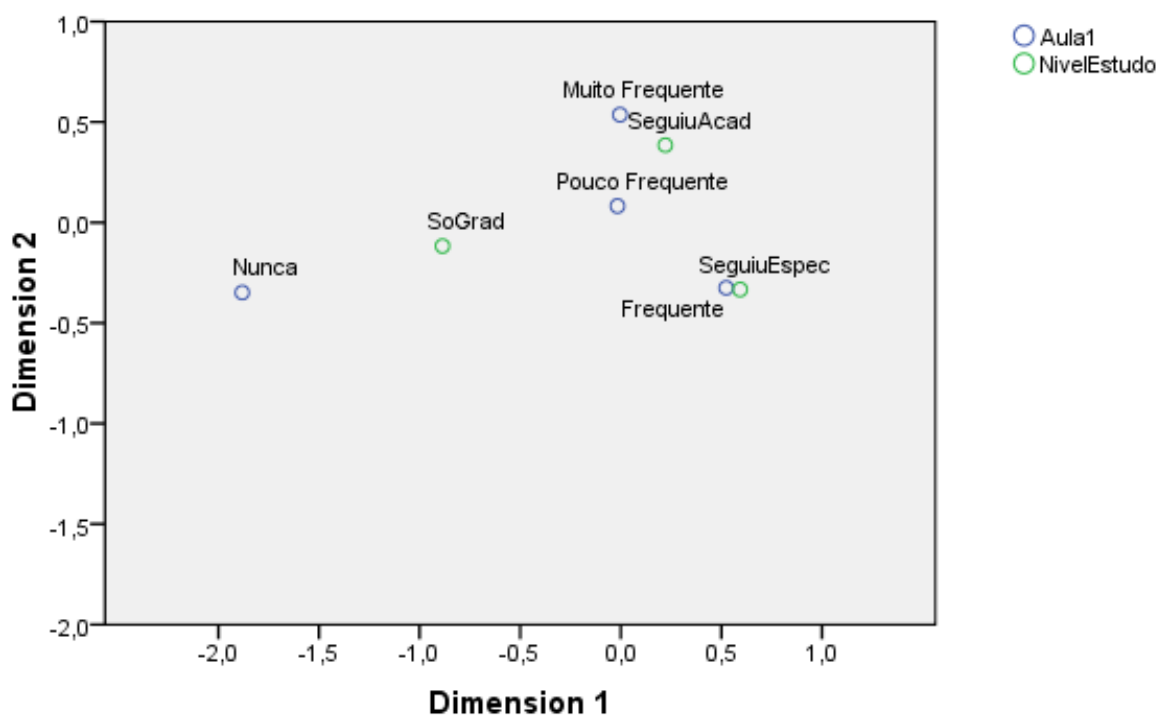

Figura 50 - Mapa das relações entre as categorias de Formação e Aula.

Para quem Seguiu trajetória em pós especialização a associação é maior com Frequente. Enquanto que para quem Seguiu trajetória em pós acadêmica a associação é maior com Muito frequente. Nunca está mais relacionado com quem fez Só a graduação, entretanto esta categoria de perfil também se relaciona igualmente com Pouco frequente.

A seguir a relação entre o evento Aula e Nível hierárquico. 


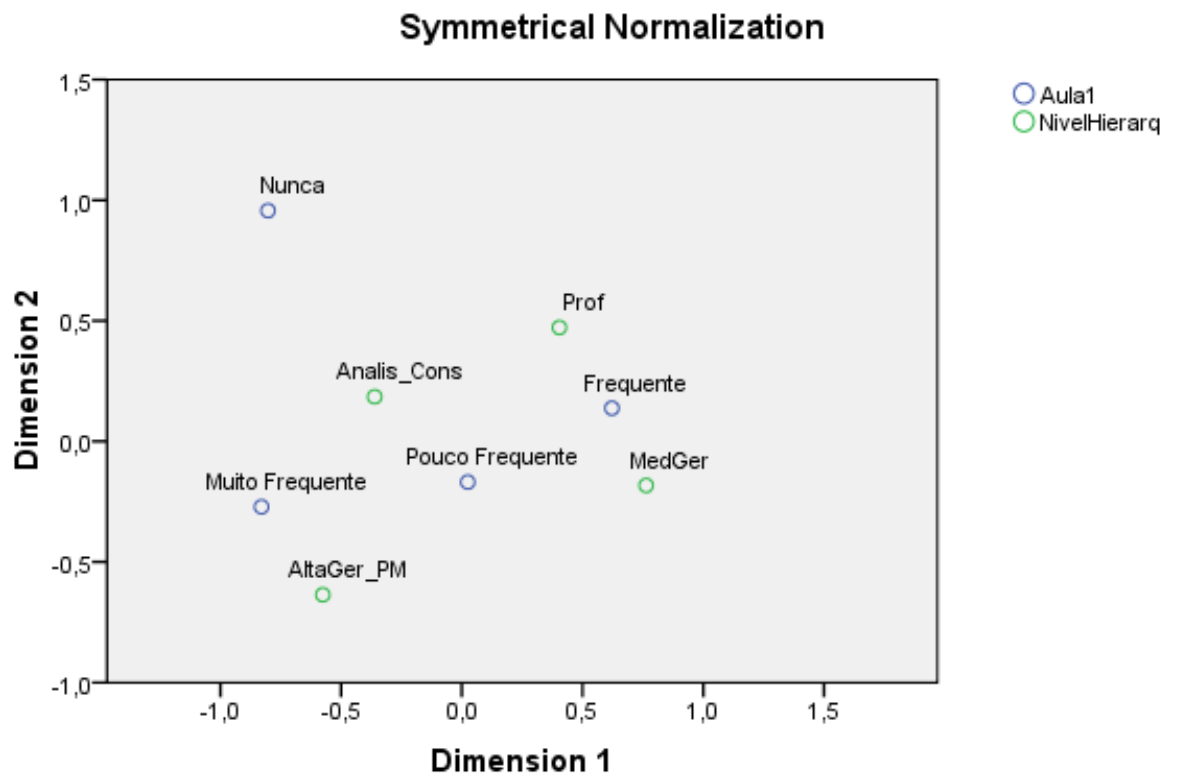

Figura 51 - Mapa das relações entre as categorias de Nível hierárquico e Aula.

Neste último mapa não temos com muita clareza as associações. De certa forma, Nunca associa-se mais com as categorias Analistas e consultores e Professores. Frequente associa-se igualmente com Professores e Média gerência. Muito frequente com Analista e consultor e Alta gestão de pequena e média empresa. E, Pouco frequente com todas as categorias de Nível hierárquico.

Na sequência, apresentamos os 6 mapas perceptuais do evento Palestra. Iniciamos com Idade.

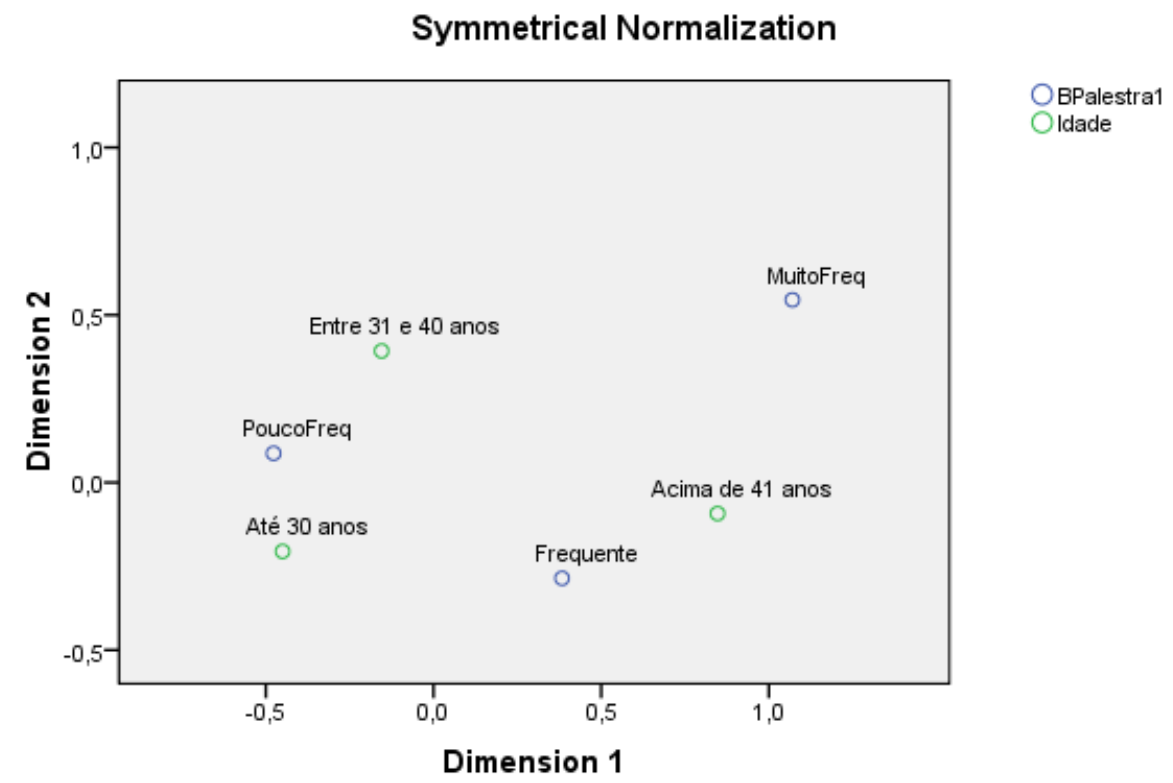

Figura 52 - Mapa das relações entre as categorias de Idade e Palestra. 
Neste mapa, identificamos dois agrupamentos, um em torno de Pouco frequente, que estão as categorias Até 30 anos e Entre 31 e 40 anos, e outro com relações mais dispersas em torno de Acima de 41 anos, que reúne as categorias de alta frequência.

Symmetrical Normalization

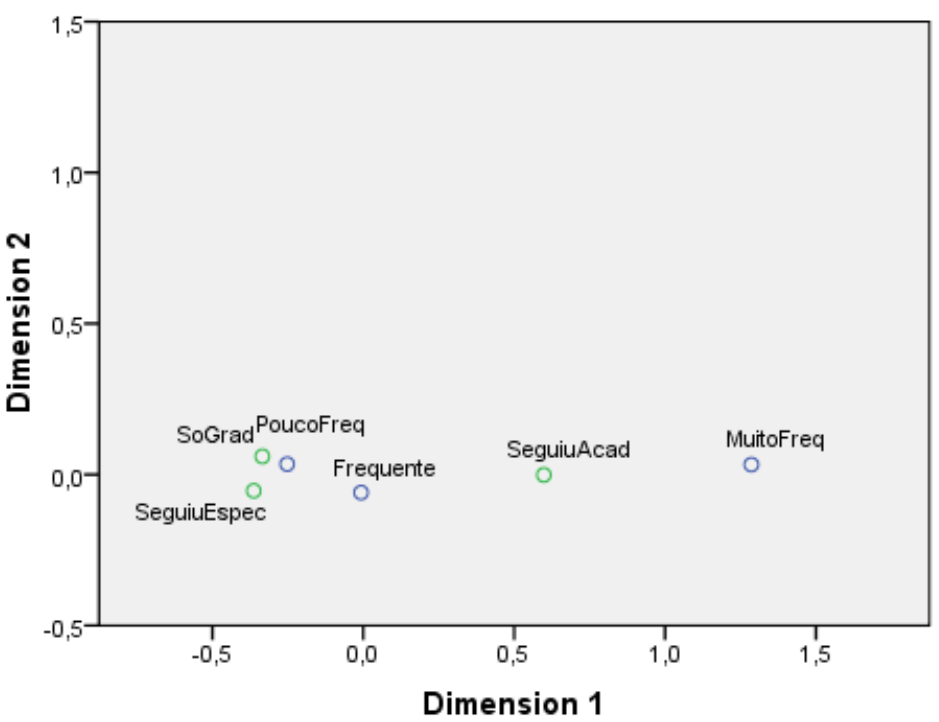

Figura 53 - Mapa das relações entre as categorias de Formação e Palestra.
OBPalestra1

NivelEstudo

Pelo último mapa, Palestra é algo mais frequente para quem Seguiu trajetória em pós acadêmica do que para aqueles das categorias Só graduação e Seguiu pós em especialização, que se posicionam próximo à categoria Pouco frequente.

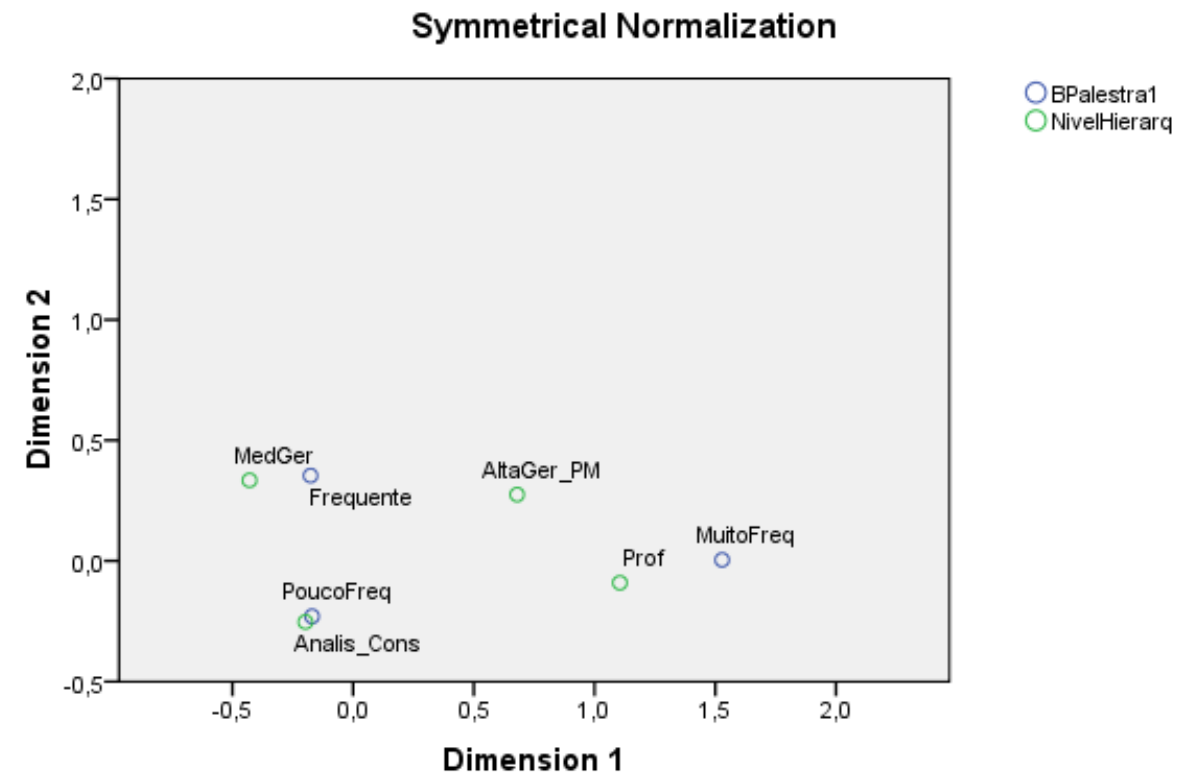

Figura 54 - Mapa das relações entre as categorias de Nível hierárquico e Palestra. 
Palestra é Pouco frequente para quem é Analista e consultor, ao contrário de quem é Professor, que está próximo a Muito frequente. Para a Média gerência é Frequente e para Alta Gerência de pequena e média empresa encontra-se associada com Frequente e Muito frequente.

Symmetrical Normalization

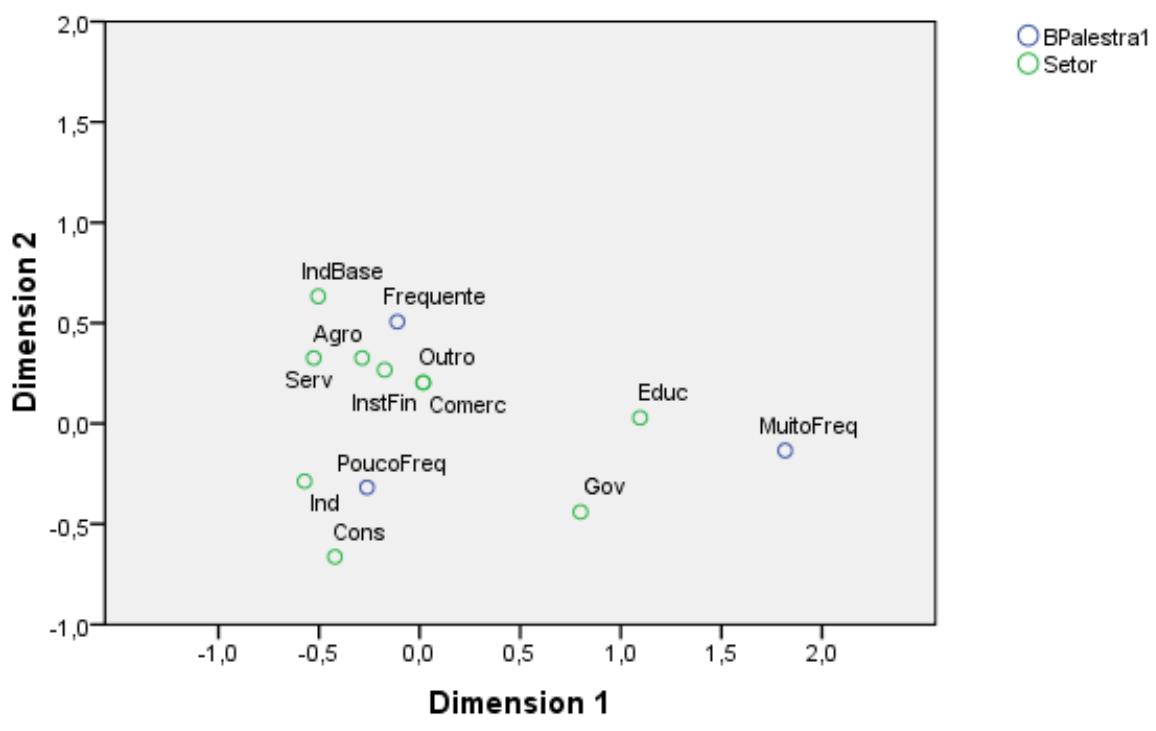

Figura 55 - Mapa das relações entre as categorias de Setor e Palestra.

Para Setor da organização, Muito frequente associa-se mais com Educação e Governo, enquanto que Pouco frequente associa-se com Indústria e Consultoria. Os demais setores tendem a se associar com Frequente.

\section{Symmetrical Normalization}

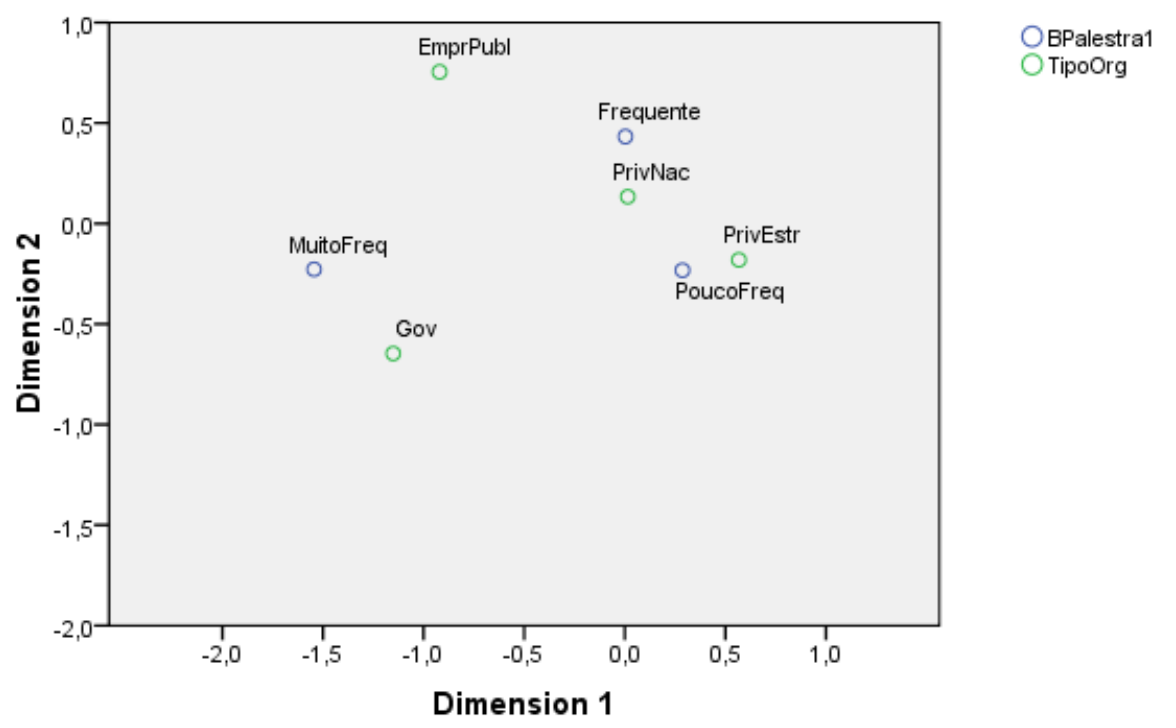

Figura 56 - Mapa das relações entre as categorias de Tipo de organização e Palestra. 
Em relação ao Tipo de organização, Palestra é Muito frequente para Governo. Já para a Empresa Pública é algo associado com as duas categorias de alta frequência. Para as organizações privadas, a Nacional relaciona-se primeiro com Frequente antes de Pouco frequente, e a Estrangeira o oposto.

O próximo mapa apresenta a relação entre Curso e Aula particular.

Symmetrical Normalization

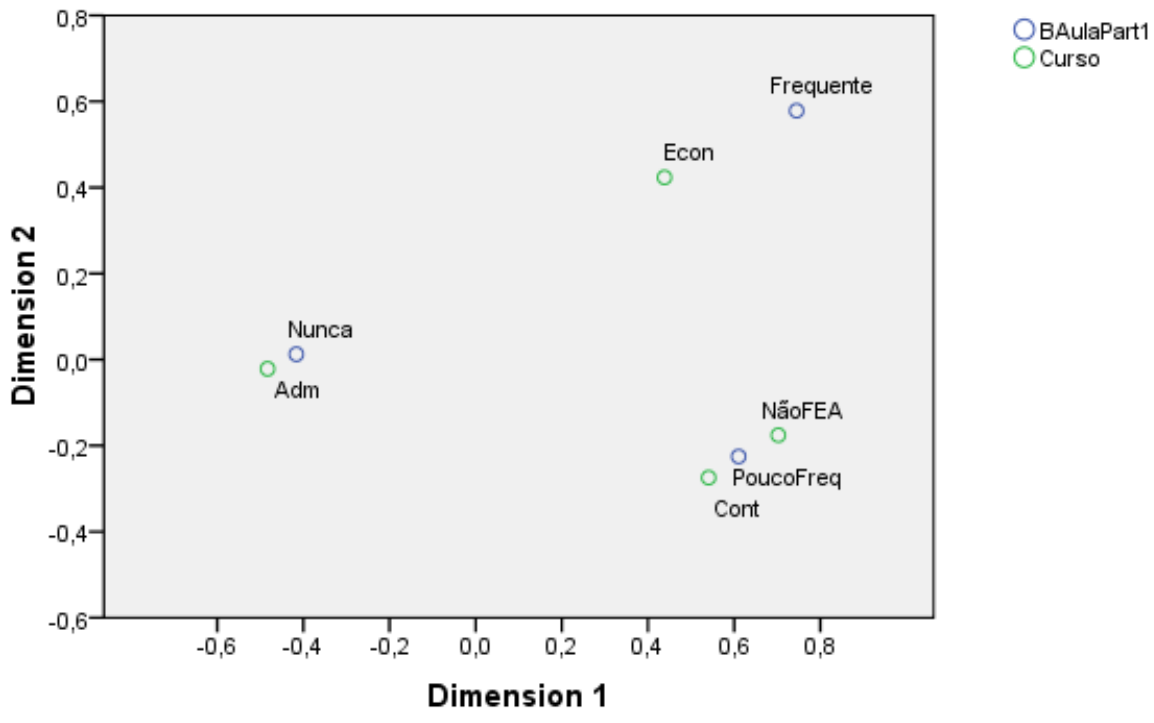

Figura 57 - Mapa das relações entre as categorias de Curso e Aula particular.

A interpretação do mapa representa que os Administradores nunca fazem uso de Aula particular. Contabilistas e pessoas que só fizeram a pós-graduação na FEA atribuíram Pouca frequência. Os Economistas possuem proximidade maior com Frequente.

O último mapa do grupo de eventos de aprendizagem conceitual apresenta a relação entre as categorias do evento Aula particular e Tempo de organização. 


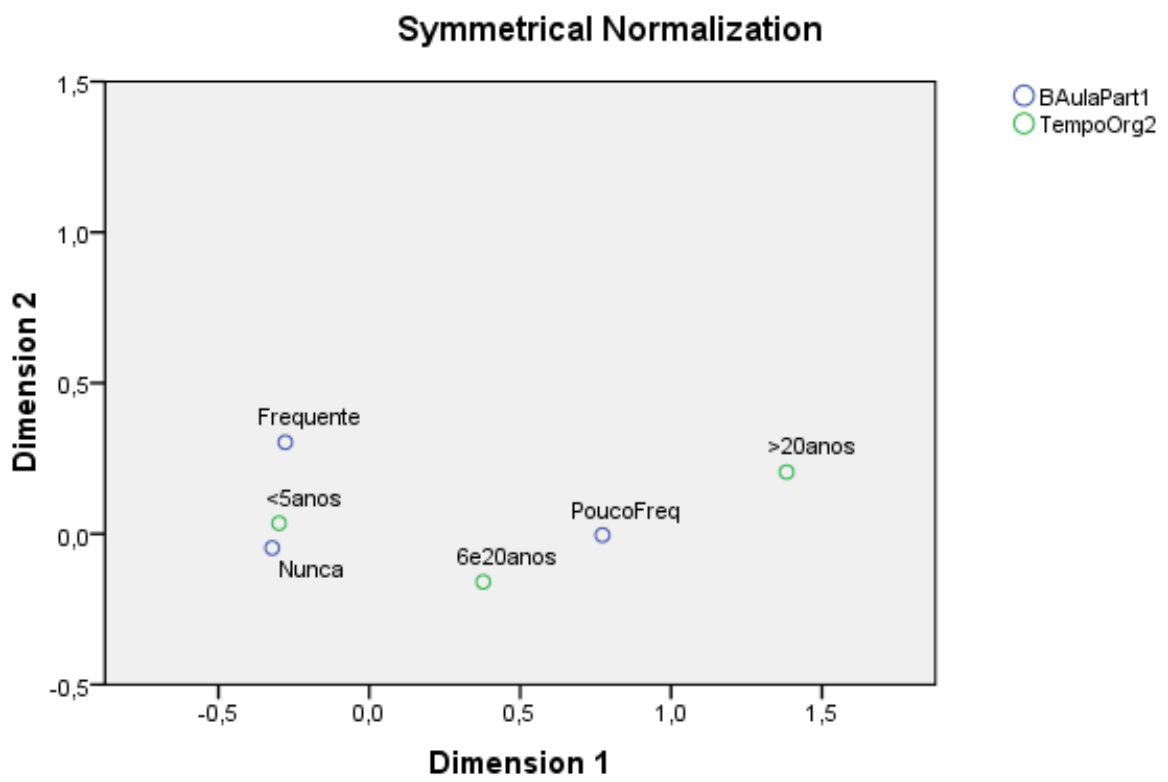

Figura 58 - Mapa das relações entre as categorias de Tempo na organização e Aula particular.

Pouco frequente associa-se mais com as categorias Entre 6 e 20 anos e Acima de 20 anos. No grupo do lado esquerdo do mapa, temos Frequente e Nunca próximo ao Menos de 5 anos.

\subsubsection{Eventos de Aprendizagem Experiencial Induzida}

$\mathrm{Na}$ Aprendizagem Experiencial Induzida, 4 eventos foram avaliados. Estes são caracterizados por serem formais e não intencionais. No gráfico abaixo, temos um painel que reúne os gráficos de frequência.

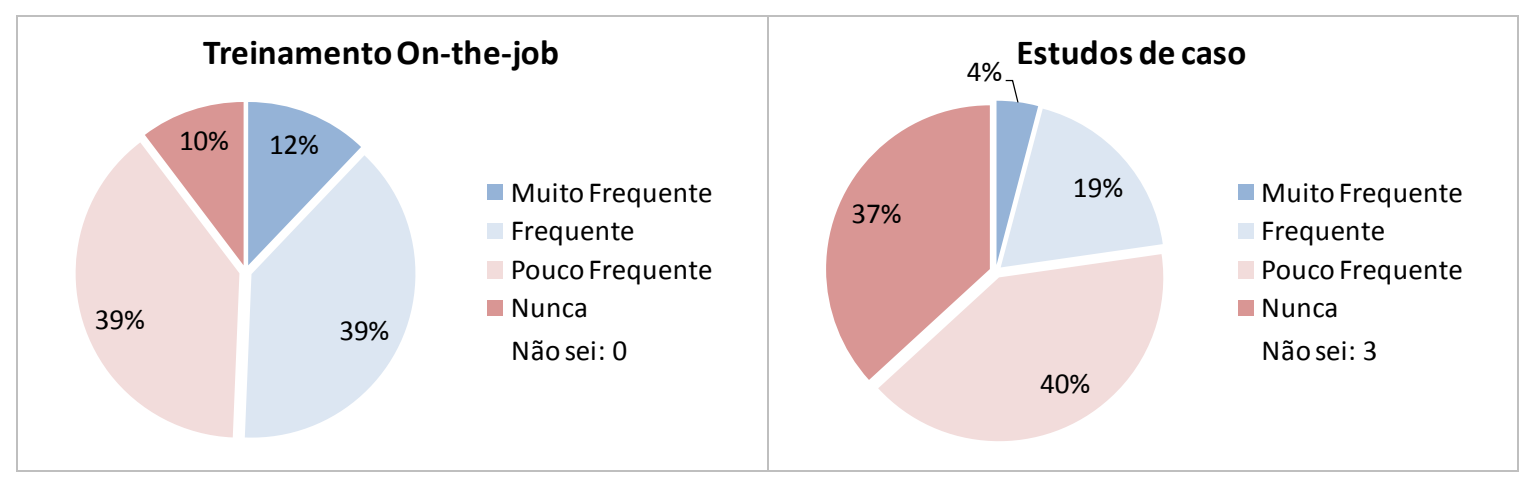




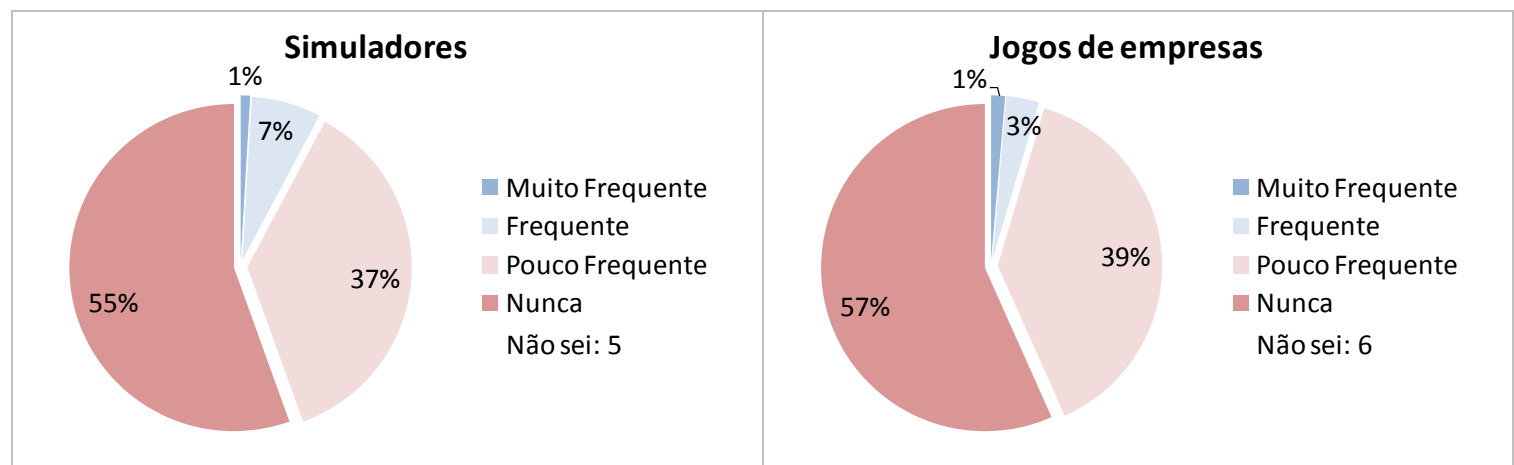

Figura 59 - Painel de gráficos de frequência dos eventos de Aprendizagem Experiencial Induzida.

Já é visível que os três eventos são pouco frequentes. Inclusive é notável a participação do Nunca em Jogos de empresas e Simuladores, com 57\% e 55\%, respectivamente. Em Estudos de caso, aproximadamente quatro quintos estão agrupados em Nunca e Pouco Frequente. O único evento que apresenta equilíbrio entre as altas e baixas frequências é o Treinamento onthe-job.

$\mathrm{Na}$ expectativa de encontrar alguma relação entre as variáveis de perfil e de eventos de aprendizagem experiencial induzida, apresentamos na tabela abaixo os resultados dos testes de Qui-Quadrado.

\begin{tabular}{|c|c|c|c|c|}
\hline & 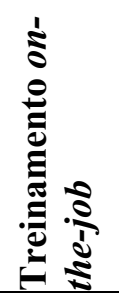 & 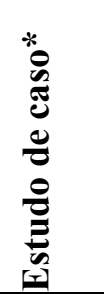 & 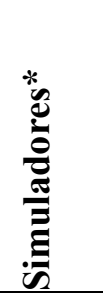 & 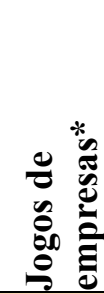 \\
\hline Idade & 0,760 & 0,074 & 0,434 & 0,015 \\
\hline Curso & 0,564 & 0,024 & 0,241 & 0,103 \\
\hline Formação & 0,090 & 0,159 & 0,440 & 0,441 \\
\hline Cursa alguma pós & 0,431 & 0,245 & 0,392 & 0,778 \\
\hline Onde mora & 0,437 & 0,824 & 0,505 & 0,517 \\
\hline Status profissional & 0,000 & 0,043 & 0,208 & 0,148 \\
\hline Nível hierárquico & 0,113 & 0,017 & 0,316 & 0,143 \\
\hline Porte da organização & 0,008 & 0,800 & 0,530 & 0,306 \\
\hline Setor da organizacão & 0,072 & 0,301 & 0,124 & 0,591 \\
\hline Tipo de organização & 0,847 & 0,102 & 0,565 & 0,506 \\
\hline Tempo na organização & 0,440 & 0,233 & 0,383 & 0,177 \\
\hline
\end{tabular}

Quadro 40 - Resultados dos testes Qui-quadrado para eventos de Aprendizagem Experiencial Induzida.

Conforme visto no quadro acima, foram identificadas 5 relações estatisticamente significativas pelo teste Qui-quadrado. A seguir os mapas perceptuais destas 5 relações. O primeiro deles apresenta uma relação entre o evento Treinamento on-the-job e Status profissional. 
Symmetrical Normalization

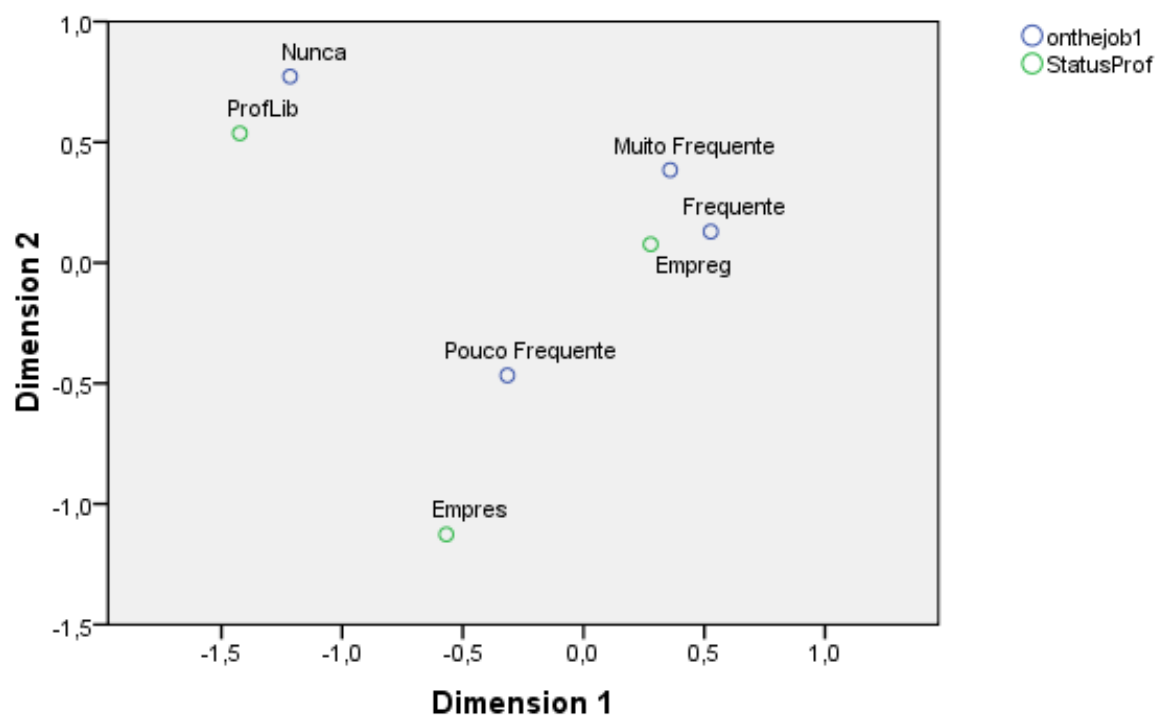

Figura 60 - Mapa das relações entre as categorias de Status profissional e Treinamento on-the-job.

Para quem é Profissional liberal este tipo de treinamento Nunca é praticado, ao contrário de quem é Empregado em uma organização, que apresenta associação maior com Muito frequente e Frequente. O Empresário apresenta relação com Pouca frequência deste tipo de evento.

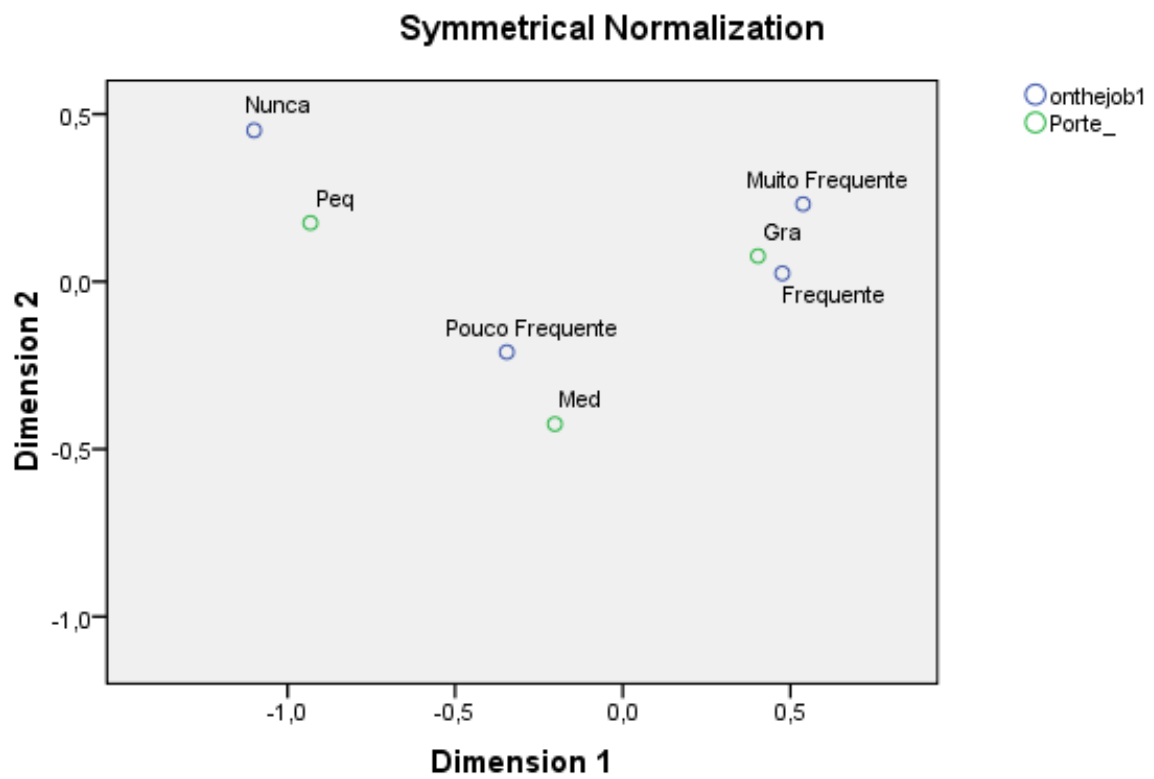

Figura 61 - Mapa das relações entre as categorias de Porte da organização e Treinamento on-the-job.

Novamente, para quem trabalha em uma Grande Empresa, a incidência deste treinamento é Muito Frequente e Frequente, enquanto para aqueles que estão na Pequena empresa este tipo 
de evento Nunca é praticado. A Média empresa foram o terceiro grupo, apresentando relação com Pouco frequência.

A seguir, apresentaremos a relação entre Estudo de caso e Curso.

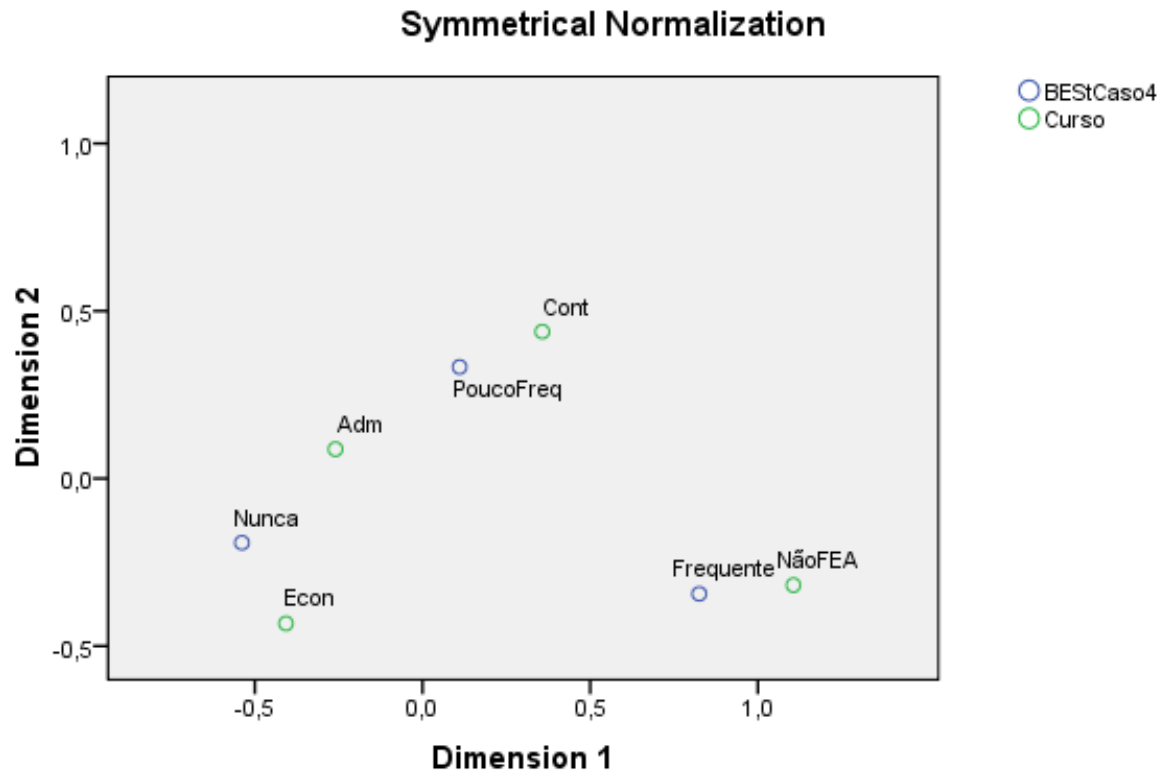

Figura 62 - Mapa das relações entre as categorias de Curso e Estudo de caso.

No mapa acima, percebemos que a categoria formada por aqueles que não fizeram graduação na FEA, mas são ex-alunos da pós, estão mais próximos do Frequente e formam um grupo isolado no canto direito do mapa. Do lado esquerdo, Nunca está associado com Economia e Administração, e Pouco frequente está associado com Contabilidade e Administração.

O segundo apresenta a relação entre o evento Estudo de caso e Status profissional. 


\section{Symmetrical Normalization}

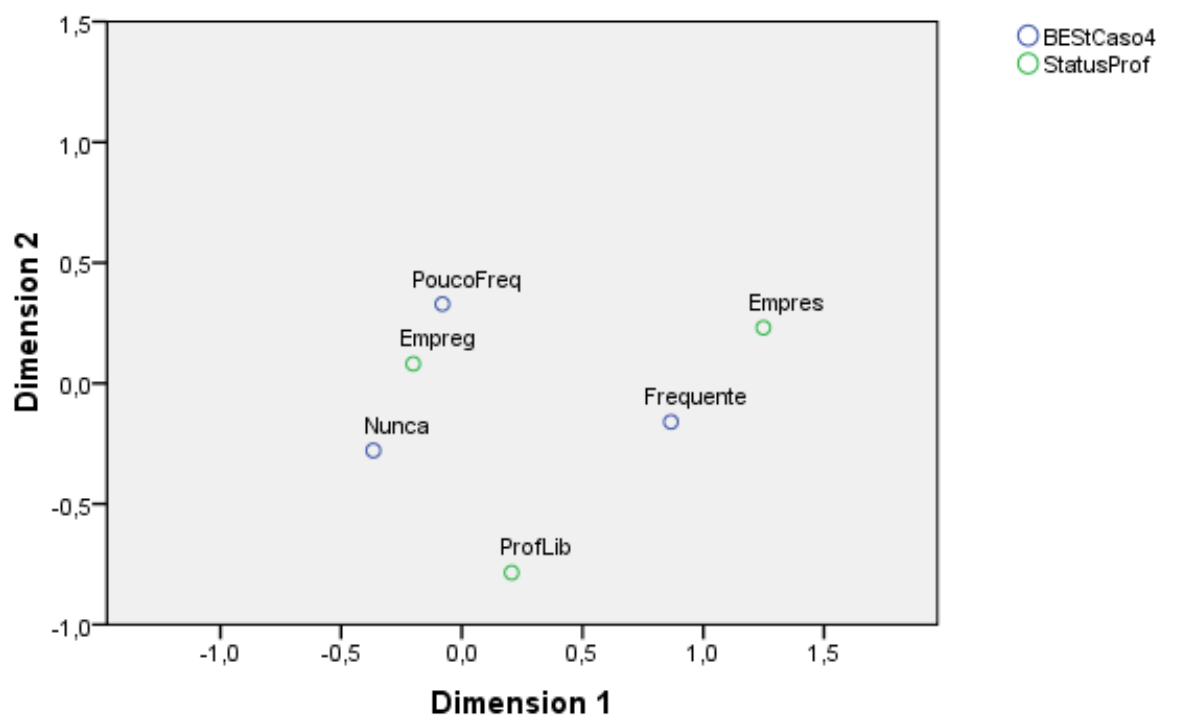

Figura 63 - Mapa das relações entre as categorias de Status profissional e Estudo de caso.

As relações não são tão claras, mas é possível visualizar que para Empregado as frequências associadas são Nunca e Pouco frequente. Para Empresário é Frequente e para Profissional liberal não há uma associação forte estabelecida.

O último mapa apresenta a relação entre as categorias do evento Jogos de empresa e Idade.

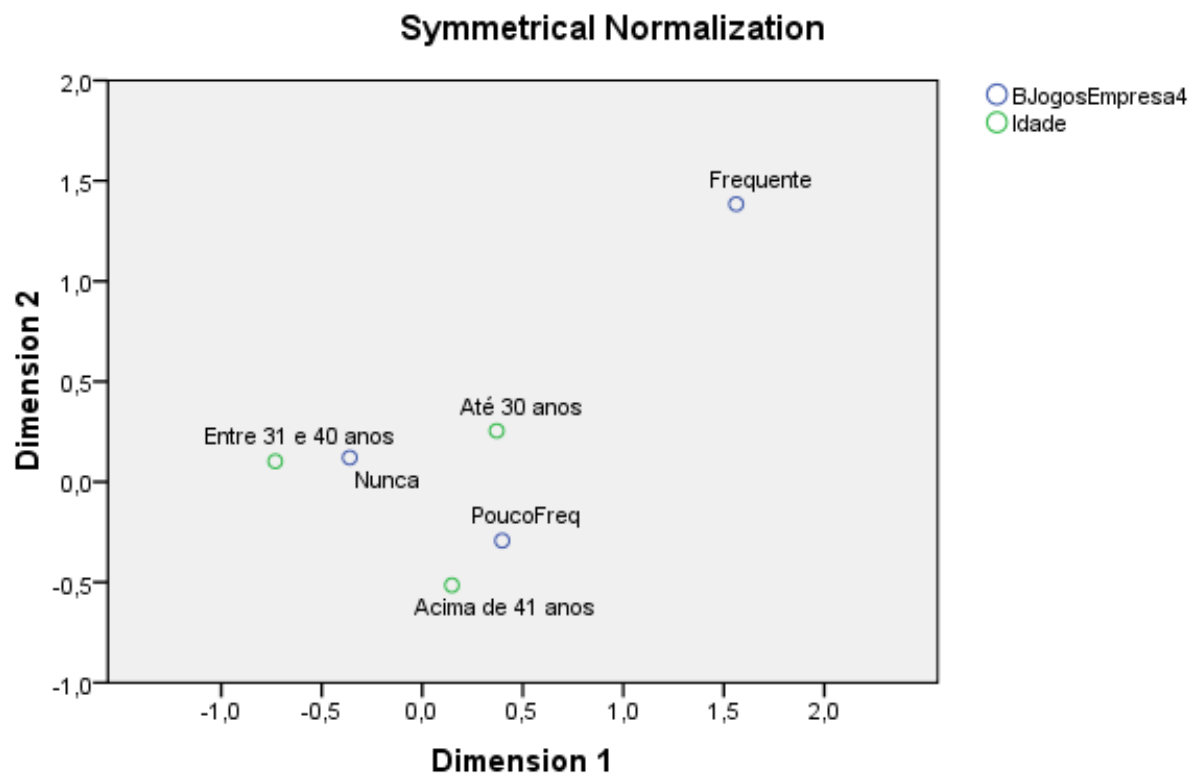

Figura 64 - Mapa das relações entre as categorias de Idade e Jogos de empresas.

A faixa Entre 31 e 40 anos está associada com Nunca. As categorias Até 30 anos e Acima de 41 anos associam-se tanto com Pouco frequente, quanto para Nunca. Frequente para Até 30 
anos é a categoria de faixa etária mais próxima, entretanto percebe-se que esta é a mais distante em relação às demais categorias de frequência para Até 30 anos.

Para finalizar esta seção apresentamos um quadro resumo que sintetiza e generaliza os principais achados dos testes ANACOR por variável de perfil:

\begin{tabular}{|c|c|}
\hline Variável de perfil & Principais achados generalizados \\
\hline Idade & $\begin{array}{l}\text { - Quanto maior a idade, menos desafios a pessoa enfrenta; } \\
\text { - Quanto maior a idade, mais frequentemente a pessoa é mentora; } \\
\text { - Quanto maior a idade, a frequência de leitura é maior; } \\
\text { - A repetição é Pouco frequente para a faixa entre } 31 \text { e } 40 \text { anos, } \\
\text { Muito frequente para a faixa até } 30 \text { anos e Frequente para a faixa } \\
\text { Acima de } 41 \text { anos; } \\
\text { - Palestra é Pouco frequente até os } 40 \text { anos, depois torna-se } \\
\text { Frequente; } \\
\text { - Jogos de empresas é Pouco frequente ou Nunca praticado por } \\
\text { todas as faixas etárias, por outro lado Frequente é mais próximo } \\
\text { dos que têm Até } 30 \text { anos. }\end{array}$ \\
\hline Curso & $\begin{array}{l}\text { - Administradores nunca fazem Aula particular, enquanto que } \\
\text { Economistas fazem uso Frequente. Para Contabilistas e os ex- } \\
\text { alunos da pós-graduação é Pouco frequente; } \\
\text { - O Estudo de caso só é Mais frequente para aqueles que só } \\
\text { fizeram na FEA a pós-graduação. Para os demais cursos é bem } \\
\text { baixo o uso deste evento. }\end{array}$ \\
\hline Formação & $\begin{array}{l}\text { - Para quem só fez a graduação, quase Nunca ele é mentor. Quem } \\
\text { seguiu pós acadêmica é Muito frequente, seguido de quem seguiu } \\
\text { pós em especialização; }\end{array}$ \\
\hline Cursa alguma pós & $\begin{array}{l}\text { - Para quem Cursa alguma pós, é mais frequente assistir Aulas e } \\
\text { Palestras. }\end{array}$ \\
\hline Onde mora & - A leitura é Pouco frequente para quem mora em Outro país. \\
\hline Status profissional & $\begin{array}{l}\text { - De certa forma, todos se relacionam com as altas frequências de } \\
\text { Mudança de perspectiva, entretanto Profissional liberal e } \\
\text { Empresário estão mais distantes de Pouco frequente do que } \\
\text { Empregado; } \\
\text { - Novamente, todos se relacionam com as altas frequências de } \\
\text { Mecanismos psicológicos, entretanto Profissional liberal e } \\
\text { Empresário estão mais distantes de Pouco frequente do que } \\
\text { Empregado; } \\
\text { - A leitura é Muito frequente para todas as categorias, entretanto } \\
\text { para Empregado também pode ser Frequente e Pouco frequente; } \\
\text { - Treinamento on-the-job tem maior frequência para quem é } \\
\text { Empregado; } \\
\text { - Estudo de caso é pouco explorado por Empregados e mais para } \\
\text { Empresários. }\end{array}$ \\
\hline Nível hierárquico & $\begin{array}{l}\text { - Analistas e consultores tem baixa frequência de serem mentores. } \\
\text { Porém, aumenta na seguinte ordem: Média gerência, Alta gerência } \\
\text { de pequena e média empresa e Professor, o mais frequente; } \\
\text { - Analistas e consultores leem pouco, Média gerência lê } \\
\text { frequentemente, mas são os Professores e Alta gerência de } \\
\text { pequena e média empresa que leem com Muita frequência; }\end{array}$ \\
\hline
\end{tabular}




\begin{tabular}{|c|c|}
\hline & $\begin{array}{l}\text { - Para Aula, Nunca associa-se mais com as categorias Analistas e } \\
\text { consultores e Professores. Frequente associa-se igualmente com } \\
\text { Professores e Média gerência. Muito frequente com Analista e } \\
\text { consultor e Alta gestão de pequena e média empresa. E, Pouco } \\
\text { frequente com todas as categorias de Nível hierárquico; } \\
\text { - Analistas e consultores participam menos de palestras, Média } \\
\text { gerência participa frequentemente, Alta gerência de pequena e } \\
\text { média empresa participa mais, entretanto é o Professor a categoria } \\
\text { que mais participa. }\end{array}$ \\
\hline Porte da organização & $\begin{array}{l}\text { - Ser mentor Nunca é praticado por aqueles que estão em uma } \\
\text { Pequena organização, ao contrário de quem está em uma Média. } \\
\text { Para quem está em uma Grande organização, várias associações } \\
\text { são possíveis, exceto para Muito frequente. } \\
\text { - A leitura é mais frequente na Média organização, seguida pela } \\
\text { Pequena. Nas Grandes, a leitura é pouco frequente. }\end{array}$ \\
\hline Setor da organização & $\begin{array}{l}\text { - Conexão de aprendizagem é mais frequente para Educação e } \\
\text { Instituições financeiras; seguidas por: Consultoria, Indústria de } \\
\text { base, Serviços e Agronegócios; } \\
\text { - Mudaç̧a de perspectiva é menos frequente em Governo e } \\
\text { Serviços não citados. Aumenta em Consultoria, Agronegócio, } \\
\text { Indústria, Indústria de base e Instituição financeira. Mas é muito } \\
\text { frequente mesmo em Educação, Outros setores e Comércio; } \\
\text { - Ser mentor no Governo e Instituições financeiras é pouco } \\
\text { frequente. Aumenta em Indústria de base, Comércio e Serviços não } \\
\text { citados. Entretanto é muito frequente mesmo em Educação; } \\
\text { - Leitura técnica é Muito frequente para Educação; Frequente para } \\
\text { Indústria, Indústria de base e Instituição financeira. Pouco } \\
\text { frequente para Agronegócio e Governo; } \\
\text { - Palestra Muito frequente está mais associada com Governo e } \\
\text { Educação, enquanto que Pouco frequente associa-se com Indústria } \\
\text { e Consultoria. Os demais tendem a se associar com Frequente. }\end{array}$ \\
\hline Tipo de organização & $\begin{array}{l}\text { - Governo e Empresa pública tendem a trabalhar menos em grupo } \\
\text { do que a iniciativa privada; } \\
\text { - A iniciativa privada tende a oferecer mais Projetos desafiadores } \\
\text { do que a Empresa pública e mais ainda em relação ao Governo; } \\
\text { - Palestra é mais frequente para Governo e Empresa pública do que } \\
\text { para a Privada nacional, e mais ainda do que para a Privada } \\
\text { estrangeira. }\end{array}$ \\
\hline Tempo na organização & $\begin{array}{l}\text { - Quanto mais tempo na organização, menor é a frequência de } \\
\text { Projetos desafiadores; } \\
\text { - Quanto mais tempo na organização, menor é a frequência de se } \\
\text { aprender por osmose; } \\
\text { - Para quem tem Mais de } 20 \text { anos na organização, Aula particular é } \\
\text { pouco frequente. Para quem tem Menos de } 5 \text { anos, este evento } \\
\text { pode ser Nunca ou Frequente. }\end{array}$ \\
\hline
\end{tabular}




\section{CONCLUSÕES}

Nesta seção apresentamos a síntese dos principais resultados e conclusões deste trabalho.

Embora já seja constatada na teoria a relevância da aprendizagem informal, esta pesquisa aprofundou a análise da conexão entre aprendizagem e desenvolvimento de competências. Especificamos grupos de eventos de aprendizagem para tornar menos genérica a aprendizagem e também adotamos uma tipologia de competências para atestar o impacto nas diversas facetas da "entrega".

Como conclusões, pudemos comprovar que o Grupo de Eventos de Aprendizagem Experiencial é a mais relevante para todas as competências. Esta conclusão também é respaldada no aprofundamento da análise, já que no geral os eventos de aprendizagem tiveram frequência maior do que nos demais grupos. Como esta aprendizagem tem como base a experiência, a variância entre quem pratica mais frequentemente e menos um evento é influenciada por variáveis relacionadas à organização, setor e sua relação com ela. Em outras palavras, o contexto sim influencia a aprendizagem, sobretudo para os eventos de Aprendizagem Experiencial, pois oferece à pessoa um conjunto de desafios e oportunidades de aprendizagem diferentes.

O Grupo de Eventos de Aprendizagem Provocada, que com a anterior formam a aprendizagem informal, foi o segundo em relevância também para o desenvolvimento de todas as competências. Também é verificada uma alta frequência em relação aos seus eventos de aprendizagem avaliados. Como verificada na teoria, as pessoas aprendem observando e refletindo sobre suas ações/comportamentos e do outros. Além disso, é válido ressaltar a variância da frequência do evento Leitura técnica e da área, a qual apresenta diferentes distribuições para maioria das variáveis de perfil levantadas.

Em relação ao Grupo de Evento de Aprendizagem Conceitual, temos a terceira posição em relevância para o desenvolvimento das competências, sendo que um menos para o desenvolvimento da Competência Funcional e menos ainda para a Competência Social. Todos os eventos tiveram proporções de baixa frequência maiores que de alta frequência. Enquanto que para Aula e Palestra a frequência esteja equilibrada entre alta e baixa, para Treinamento 
hands-on, eLearning e Aula particular a frequência é muito baixa. Além disso, Palestra foi a variável com o maior número de relações com as variáveis de perfil deste grupo.

Por fim, o Grupo de Eventos de Aprendizagem Experiencial Induzida desenvolve menos a Competência Social, seguida da Competência Funcional e da Metacompetência. Temos também respaldada a baixa frequência dos eventos de aprendizagem ligadas a esta aprendizagem.

É curioso levantar que enquanto a estratégia de formação de lideranças da GE (General Eletric) enfatiza $70 \%$ da aprendizagem on-the-job (CORPORATE LEADERSHIP COUNCIL, 2004 apud MARSICK et al, 2006), as organizações ainda não praticam este evento, visto que metade dos respondentes atribuiu baixa frequência. Por outro lado, por misturar características da aprendizagem informal, o treinamento on-the-job foi o evento com maior frequência do grupo de Aprendizagem Experiencial Induzida.

Ademais, na seção de aprofundamento de análise, inúmeras conclusões puderam ser levantadas ao confrontar as frequências dos eventos de aprendizagem com as características de perfil. Algumas comprovam fatos já bem constatados, como por exemplo: a frequência para ser mentor é maior quando se é mais velho. Entretanto, algumas abrem campo para novos estudos, como por exemplo: a frequência de leitura aumenta com a idade.

As variáveis de perfil que mais apresentaram relações entre as categorias foram: Idade, Status profissional, Setor da organização, Nível hierárquico, Tipo de organização e Tempo na organização. Na outra perspectiva, os eventos de aprendizagem com mais relações entre as categorias foram: Livros técnicos e da área, Palestras, Ser mentor e Aulas.

Para encerrar a conclusão, é válido também citar os eventos de aprendizagem cuja distribuição é totalmente aleatória e que não foi possível identificar associações: Reflexão, Reflexão sobre comportamento de outro, Observação, Feedback, Mentoring, Treinamento hands-on, eLearning e Simuladores. 


\section{CONSIDERAÇÕES FINAIS}

\subsection{Sobre os Achados}

Este estudo se propôs a analisar a relação entre grupos de eventos de aprendizagem e desenvolvimento de competência. Buscou-se compreender quais deles eram considerados mais relevantes para o desenvolvimento de diferentes competências do indivíduo no trabalho.

Para se chegar a isso, buscou-se primeiro na revisão bibliográfica a compreensão geral do que é aprendizagem e de como os adultos aprendem. Na seqüência, buscou-se compreender os termos que seriam avaliados, assim pesquisou-se o significado de evento de aprendizagem e competência, sendo a parte mais importante a revisão das tipologias e estruturas de eventos de aprendizagem e competência.

Desta revisão, quatro grupos de eventos de aprendizagem emergiram: Aprendizagem Conceitual, Aprendizagem Provocada, Aprendizagem Experiencial e Aprendizagem Experiencial Induzida. Estes grupos foram confrontados com quatro tipos de competências que foram selecionados a partir da análise de 28 tipologias: Social, Funcional, Cognitiva e Metacompetência.

O questionário estruturado foi submetido a uma pesquisa quantitativa na internet e contou com a análise de 223 respondentes válidos. A amostra foi composta por ex-alunos da FEAUSP dos cursos de administração, economia e contabilidade. Foram aplicados testes ANOVA para avaliar as hipóteses e testes ANACOR para o aprofundamento da análise.

Das 7 hipóteses testadas, 5 hipóteses foram aceitas e 2 rejeitadas. $\mathrm{O}$ resumo dos achados encontra-se no Quadro 25 da página 116. Os resultados gerais evidenciaram a importância dos grupos de eventos de aprendizagem informal, sobretudo o de Aprendizagem Experiencial para o desenvolvimento das quatro competências avaliadas. Os grupos de eventos de aprendizagem formal desenvolvem menos todas as competências e são ainda menos relevantes para o desenvolvimento da Competência Social e da Competência Funcional, em especial para a primeira citada. 
No aprofundamento da análise, 24 eventos tiveram a frequência analisada e foram confrontados com 11 variáveis de perfis. Dos 264 testes Qui-quadrado realizados, 35 deles apresentaram significância estatística, dos quais foi possível analisar a relação entre as categorias em 34 mapas perceptuais gerados pela ANACOR.

\subsection{Limitações do Estudo}

Pelo método de amostragem não-aleatória por conveniência utilizado, os achados deste estudo não podem ser generalizados para toda a população. Logo, devem ser vistos por seu caráter exploratório.

O instrumento de pesquisa levantou a percepção dos respondentes. Estas percepções podem ser influenciadas por diversos fatores que vão desde a tentativa de transmitir algo positivo, até a presença marcante de um fato próximo.

Além disso, o instrumento não abordou algumas variáveis contextuais para complementar o estudo da relação, já que ampliariam o escopo inicial traçado e tornariam o instrumento complexo demais para ser respondido. Exemplo destas variáveis são: quão independente o indivíduo é na promoção de eventos de aprendizagem, a motivação em relação a trabalhar na empresa, conexão com evolução de carreira e com instrumentos de avaliação.

\subsection{Delineações para Pesquisas Futuras}

Este estudo abre um leque amplo de novas pesquisas. Apresentamos três possibilidades: uma que se aprofunde, outra que foi tentada e uma terceira que abre um novo campo a se estudar.

Para um estudo que complemente a relação entre desenvolvimento de competências e grupos de eventos de aprendizagem recomenda-se a realização de uma nova pesquisa em uma única organização. Assim, conhecendo bem os eventos de aprendizagem promovidos e comparando-os com novas variáveis de evolução de carreira e histórico de avaliações, por 
exemplo, pode-se estabelecer novas relações. Além disso, políticas de RH e cultura organizacional seriam trabalhadas, inclusive com a possibilidade de uma análise qualitativa para discutir os resultados.

Como segunda possibilidade, neste estudo tentou-se sem sucesso a aplicação da Análise de Variância Múltipla com medias repetidas (MANOVA Repeated Measures ou General Linear Models with Repeated Measures), entretanto dado ao excesso de variáveis dependentes, tamanho da amostra, médias de importância próximas e, principalmente à complexidade e à inseparabilidade do conceito de competência, tornou-se inviável identificar um modelo que explique alguma relação com todas as competências. Recomenda-se que se estude apenas um dos tipos de competência por vez para que se possam aprofundar os resultados.

Por fim, por conta da grande quantidade de variáveis de perfil relacionadas à organização com associação estatisticamente significante com os eventos de Aprendizagem Experiencial, recomenda-se um estudo mais profundo considerando a relação interníveis: indivíduo, organização e ambiente da organização. Além disso, na revisão bibliográfica deste trabalho foi identificada a influência do contexto no processo de aprendizagem. 


\section{REFERÊNCIAS}

ABBAD, G. \& MOURÃO, L. (orgs) Treinamento, Desenvolvimento e Educação em Organizações e Trabalho: Fundamentos para a Gestão de Pessoas. Porto Alegre: Artmed, 2006.

ABBAD, G. da S.; BORGES-ANDRADE, J. E. Aprendizagem humana em organizações de trabalho. In: ZANELLI, José C.; BORGES-ANDRADE, J. E.; BASTOS, A. V. B. (Org.). Psicologia, organizações e trabalho no Brasil. p. 237275. Porto Alegre: Artmed, 2004.

ALLEN, Mark. Assessing Effectiviness in Four Corporate Universities. California, 1999. (Doctor of Philosophy in Education). University of Southern California.

ALTONJI, Joseph G.; SPLETZER, James R. Worker Characteristics, Job Characteristics, and the Receipt of On-the-job Training. Industrial and Labor Relations Review 45. P.58-79. October, 1991.

ANDERSON, L.W.; KRATHWOHL, D.R. A Taxonomy for Learning, Teaching, and Assessing: a Revision of Bloom's Taxonomy of Educational Objectives. New York: Addison-Wesley Longman, 2001.

ANTONELLO, C. Alternativas de Articulação entre Programas de Formação Gerencial e as Práticas de Trabalho: uma Contribuição no Desenvolvimento de Competências. Porto Alegre, 2004. Tese (Doutorado em Administração) - Programa de Pós-Graduação em Administração, Escola de Administração, Universidade Federal do Rio Grande do Sul.

ARGYRIS, C. On Organizational Learning. 2nd. Oxford: Ed. Blackwell, 1999.

ARGYRIS, C.; SCHÖN, D.A. Organizational Learning: a Theory of Action Perspective. Workingham: Addison-Wesley, 1978.

ARNOLD, Gertrude Lee. Friend raisers and fund raisers: Alumni relations and development in large, public universities. Michigan, 2003. Dissertation (Doctor of Philosophy in Education). University of Michigan.

AULETE, C. Minidicionário Contemporâneo da Língua Portuguesa. Rio de Janeiro: Nova Fronteira, 2004.

AUSUBEL, D.P.; NOVAK, J.D.; HANESIAN, H. Pscicologia Educativa. Cidade do México: Holt Rinehart \& Wiston, 1983.

BANDLER, R.; GRINDER, J. Frogs Into Princes: Neuro-Linguistic Programming. Moab, UT: Real People Press, 1979.

BANDURA, A. Foundations of Thought and Action: a Social Cognitive Theory. New Jersey: Prentice-Hall, Englewood Cliffs, 1986. 
BANDURA, A. Social Learning Theory. New Jersey: Prentice-Hall, Englewood Cliffs, 1977.

BATENSON, G. Steps to an Ecology of Mind. New York: Ballentine Books, 1972.

BEAUMONT, G. Review of 100 NVQs and SVQs. London: Department for Education and Employment, 1996.

BECKETT, D.; HAGER, P. Life, Work and Learning: Practice in Postmodernity. London: Routledge, 2002.

BILLET, S. Learning in the Workplace: Strategies for effective practice. Crows Nest NSW: Allen \& Unwin, 2001.

BISHOP, John. The Incidence of and Payoff to Employer Training. Cornell University Center for Advanced Human Resource Studies Working Paper. P.94-117. July, 1994.

BITENCOURT, C. A Gestão de Competências Gerenciais: a Contribuição da Aprendizagem Organizacional. Porto Alegre, 2001. Tese (Doutorado em Administração) - Programa de Pós Graduação em Administração, Escola de Administração, Universidade Federal do Rio Grande do Sul.

BLOOM, B.S. Taxonomy of Educational Objectives: The Classification of Educational Goals, Handbook 1: Cognitive Domain. London: Longmans Green and Company, 1956.

BOSHIER, Roger W. Education Participation Scale. Vancouver: Learningpress Itda., 1982.

BOSHIER, Roger W. Motivational Orientations of Adult Education Participants: a Factor Analytic Exploration of Houle's Typology. Adult Education, 21. P.3-26. 1971.

BOSHIER, Roger W. Motivational Orientations Revisited: Life Space Motives and the Education Participation Scale. Adult Education, 27. 1977.

BOYATZIS, R.E. The Competent Manager. New York: Wiley, 1982.

BRANSFORD, John D.; BROWN, Ann L.; COOKING, Roodney R. How People Learn: Brain, Mind, Experience and School. Expanded ed. Washington DC: National Academy Press: 2000.

BROOKFIELD, Stephen D. Understanding and Facilitating Adult Learning. San Francisco: Jossey-Bass, 1986.

BRUCE, L.; ARING, M.K.; BRAND, B. Informal Learning: the New Frontier of Employee \& Organizational Development. Economic Development Review, 15(4), 12-18, 1998.

BRUNDAGE, D.H.; MACKERACHER, D. Adult Learning Principles and their Application to Program Planning. Toronto: Ministry of Education, 1980. 
BURGESS, P. Reasons for Adult Participation in Group Educational Activities. Adult Education, 22(1). P.3-29. 1971.

BURGOYNE, J.G.; HODGSON, V.E. Natural Learning and Managerial Action: a Phenomenological Study in the Field Setting. Journal of Management Studies, 20(3), 387-399, 1983.

BUZAN, T. Harnessing the Para Brains. Colt Books Ltda: Cambridge, 1988.

CANGELOSI, V.E.; DILL, W.R. Organizational Learning: Observations toward a Theory. Administrative Science Quarterly, 10, p.175-203, 1965.

CARP, A.; PETERSON, R.; ROELFS, P. Adult Learning interests and experiences, In: CROSS; J.R. VALEY (Organizadores). Planning Non-Traditional Programs, p.11-52. San Francisco: Jossey-Bass Publisher, 1974.

CARR-SAUNDERS, A.M.; WILSON, P. The Historical Development of Professional Associations. In: VOLLMER, H.M.; MILLS, D.L. (Eds) Professionalization (p.153157). New Jersey: Prentice-Hall, Inc., 1966.

CASSIMIRO, Wagner Toyama. Interação e integração com ex-alunos: Estudo de Caso da FEA-USP. São Paulo, 2005. Monografia (Bacharel em Administração). FEA-USP, 2005.

CELL, E. Learning to Learn from Experience. New York: State University of New York Press, 1984.

CERVERO, R.; MILLER, J.; DIMMOCK, K. The Formal and Informal Learning Activities of Practicing Engineers. Engineering Education, v.77, p.112-114, novembro, 1986.

CHEETHAM, G.; CHIVERS, G. How professionals Learn in Practice: an Investigation of Informal Learning amongst People Working in Professions. Journal of European Industrial Training, 25, 5, p.248-292, 2001.

CHEETHAM, G.; CHIVERS, G. The reflective (and competent) practitioner: a model of professional competence which seeks to harmonise the reflective practitioner and competence-based approaches. Journal of European Industrial Training, 22(7), p. 267-276, 1998.

CHEETHAM, G.; CHIVERS, G. Towards a holistic model of professional competence. Journal of European Industrial Training. 20(5), p. 20-301996.

CLOSS, Lisiane Quadrado; ANTONELLO, Cláudia Simone. Aprendizagem Transformadora: Integrando a Reflexão Crítica na Formação Gerencial. Revista Gestão.Org. Número Especial I ENEPQ. p.59-69, Novembro, 2008

COCKERILL, Tony. The Kind of Competence for Rapid Change. In: MABEY, Christopher; ILES, Paul (eds). Managing Learning. London: Routledge, 1994. 
COELHO Jr., Francisco Antônio; BORGES-ANDRADE, Jairo Eduardo. Uso do Conceito de Aprendizagem em Estudos Relacionados ao Trabalho e Organizações. Paidéia, 18(40), 221-234, 2008.

COLLEY, H.; HODKINSON, P.; MALCOLM, J. Informality and Formality in Learning. London: LSDA, 2003.

CONNER, Marcia L. Informal Learning. Disponível em: http://www.agelesslearner.com/intros/informal.html . Acessado em janeiro de 2009. 2006

CONNER, Marcia, L. Learn More Now: 10 Simple Steps to Learning Better, Smarter, and Faster. Wiley, 2004.

CORREIA, Fernanda Bruto da Costa; FEITOSA, Marcos Gilson Gomes; VIEIRA, Naldeir dos Santos. Aprendizagem de Integrantes de Organizações Não Governamentais na Relação com Consultores Organizacionais. XXXII Encontros da ANPAD. Rio de Janeiro, 2008.

CROSS, K.P. Adults as Learners. San Francisco: Jossey Bass, 1986.

CROSS, K.P. What adults participate - and why not. In: CROSS, K.P. Adults as Learners: Increasing Participation and Facilitating Learning. P.81-107. San Francisco: Jossey-Bass Publishers.1981.

CROSSAN, M.M. LANE, H.; WHITE, R. An Organizational Learning Framework: from Intuition to Institution. The Academy of Management Review. V.24, n.3, p.522-537, July 1999.

CUNHA, M. Prática Gerencial: Experiências Vividas de Mudança. 2003. 183f. Tese (Doutorado em Engenharia da Produção) Tese - Centro Tecnológico, Universidade Federal de Santa Catarina, Florianópolis, 2003.

CYERT, R.M.; MARCH, J.G. A Behavioral Theory of the Firm. New Jersey: Englewook Cliffs, 1963.

DAFT, R.; WEICK, K. Toward a Model of Organizations as Interpretation Systems. Academy of Management Review, v.9, n.2, p.284-295, 1983.

DAHLMAN, C.; ZENG, D.Z.; WAGNER, S. Enhancing China's Competitiveness through Lifelong Learning. World Bank Institute: Washington, 2007.

DARKENWALD, Gordon; MERRIAM, S. Adult Education: Foundations of Practice. New York: Harper \& Row, 1982.

DARRAH, C.N.; Learning and Work: an Exploration in Industrial Ethnography. London: Garland Publishing, 1996.

DAVENPORT, J.; DAVENPORT, J. A Chronology and Analysis of the Andragogy Debate. Adult Education Quarterly, 35(3), p.152-159, 1985. 
DAVIDSON-SHIVERS, Gayle V.; INPORNJIVIT, Kit; SELLERS, Kim. Using Alumni and student databases for program evaluation and planning. College Student Journal. Mobile: [s.n.], dez. 2004. Vol.38, Iss. 4; p. 510-521.

DAVIES, J.; EASTERBY-SMITH, M. Learning and Developing form Work Experiences. Journal of Management Studies, 21(2), 167-183, 1984.

De BONO, E. The Use of Lateral Thinking. Penguim: Hardmondsworth, 1967.

DESFROGES, Charles. Knowledge Base for Teaching and Learning. Teaching and Learning Research Programme Newsletter. 3:3-4.2001

DIAS, Gisele B.; BECKER, Grace V.; DUTRA, Joel Souza; RUAS, Roberto. GHEDINE, Tatiana. Revisando a Noção de Competências na Produção Científica em Administração: Avanços e Limites. In: DUTRA, Joel Souza; FLEURY, Maria Tereza Leme; RUAS, Roberto (orgs.). Competências: Conceitos, Métodos e Experiências. São Paulo: Editora Atlas, 2008

DOMINGUES, L. H. A gestão dos recursos humanos e o desenvolvimento social das empresas: a renegociação coletiva como um dos elementos viabilizadores. Lisboa: Instituto Superior de Ciências Sociais e Políticas, 2003.

DOUGLAS, Michael. Why 'soft skills' are an essential part of hard world of business. The British Journal of Administrative Management. Iss.34; pg.34. Orpington, Dec 2002/Jan 2003.

DOZ, Yves. Les Dilemmes de la Gestion du Renouvellement des Compétences Clés. Revue Française de Gestion, n97, p.92-104, 1994.

DUTRA, Joel Souza. Gestão de Pessoas: Modelos, Processos, Tendências e Perspectivas. São Paulo: Atlas, 2002.

EBOLI, Marisa. Educação Corporativa no Brasil: Mitos e Verdades. São Paulo: Editora Gente, 2004.

EHRENBERG, Ronald G.; SMITH, Robert S. Modern Labor Economics: Theory and Public Policy. 9aㅗ edition. New York: Pearson Education, Inc., 2005.

ELMUTI, Edan. Can management be taught?: If so, what should management education curricula include and how should the process be approached? Management Decision. Vol.42, Iss. 3/4; p.439. London: 2004.

ENGESTRÖM, Y. The New Generation of Expertise: Seven Theses. In: RAINBIRD, H.; FULLER, A.; MUNRO, A. (eds) Workplace Learning in Europe. London: Chartered Institute of Personnel and Development, 2001.

ENGESTRÖM, Y. Training for Change: New Approach to Instruction and Learning. Geneva: International Labour Office, 1994.

ERAUT, M. Non-Formal Learning and Tacit Knowledge in Professional Work. British journal of Educational Psychology, 70: 113-136, 2000. 
EUROPEAN COMISSION. Communication from the Commission: Making a European Area of Lifelong Learning a Reality. Brussels, 20 December 2001.

EUROPEAN COMISSION. European Employment Observatory, Review: autumn 2007. Office for Official Publications of the European Communities: Luxembourg, 2008 .

EUROSTAT. Classification of Learning Activities - Manual. Office for Official Publications of the European Communities: Luxembourg, 2006.

FÁVERO, Luiz Paulo; BELFIORE, Patrícia; SILVA, Fabiana Lopes; CHAN, Betty Lilian. Análise de Dados: modelagem multivariada para tomada de decisões. São Paulo: Editora Campus Elsevier:, 2009.

FERREIRA, A.B.H. Novo dicionário da Língua Portuguesa. Nova Fronteira, Rio de Janeiro, 1999.

FIOL, C.M.; LYLES, M.A. Organizational Learning. The Academy of Management Review, v.10, n.4, October 1985.

FLEURY, Maria Tereza Leme; FLEURY, Afonso. Estratégias Empresariais e Formação de Competências: um Quebra-Cabeça Caleidoscópico da Indústria Brasileira. 2ªEd., São Paulo: Editora Atlas, 2001.

FONSECA, Dóris. Conceitos de Competências. Material do curso de Pósgraduação Lato Sensu em Gestão do Conhecimento e Inteligência Empresarial do C.R.I.E. - Centro de Referência em Inteligência Empresarial. http://www.crie.ufrj.br/index.html 2003.

FREIRE, Paulo. Pedagogia do oprimido. Rio de Janeiro: Paz e Terra, 1970.

FULLER, A. and UNWIN, L. Young People as Teachers and Learners in the Contemporary Workplace: Challenging the Novice/Expert Dichotomy. International Journal of Training and Development, 8 (1), 2004.

FULLER, Alison; ASHTON, David; FELSTEAD, Alan et al The impact of Informal Learning at Work on Business Productivity. Final Report to the DTI. University of Leicester. The Centre for Labour Market Studies. October, 2003.

GAGNÉ, Robert Mills. The Conditions of Learning. New York: Holt, Rinehart and Winston, 1965.

GALLUP, G. The Absorption rate of Ideas. Public Opinion Quartely. 19 (3), p.234242, 1955

GARRATT, B. Creating a Learning Organization: A Guide to Leadership, Learning and Development. Cambridge: Director Books, 1990.

GARVIN, D.A. Aprendizagem em Ação: um Guia para Transformar sua Empresa em uma Learning Organization. Rio de Janeiro: Qualitymark, 2002. 
GARVIN, D.A. Construindo a Organização que Aprende. In: Coleção Harvard Business Review. Gestão do Conhecimento. Rio de Janeiro: Campus, p.50-81, 2000 .

GEARHART, David, G. A study of the relationship between the preparation for an initiation of a capital fundraising campaign in a major research university and two types of organizational structure. Dissertation (Doctor of Education) University of Arkansa. Fayetteville: [s.n.], jan. 1989.

GENTE DA FEA. FEA-USP. Ano 01, edição 20 de agosto. São Paulo: FEA-USP, 2005.

GEUS, A.P. de. Planning as learning. Harvard Business Review, Boston, v.66, n.2, p.70-74, mar/abr, 1988.

GIANFALDONI, Patrick. Normalisation de l'organisation productive et gestion des compétences. 1999. Disponível em : http://www.defi-univ.org//MG/pdf/9914.pdf Acesso em 12 de julho de 2009.

GIL, Antonio Carlos. Como elaborar projetos de pesquisa. $4^{a}$ ed. São Paulo: Atlas, 2002.

GOTTWALD, G. Aprendizagem de Executivos no Setor Automobilístico: Estudo de Caso na Volkswagen/Audi do Brasil. Florianópolis, 2001. Dissertação (Mestrado em Engenharia da Produção) - Centro Tecnológico, Universidade Federal de Santa Catarina.

GRACE, A. P. Taking a Critical Pose: Andragogy_Missing Links, Missing Values. International Journal of Lifelong Education, 15(5), p.382-392, 1996.

GRAMIGNA, MARIA RITA. Modelo de Competências e Gestão dos Talentos. São Paulo: Makron Books, 2002.

GREENWOOD, E. The Elements of Professionalization. In: VOLLMER, H.M.; MILLS, D.L. (Eds) Professionalization (p.9-19). New Jersey: Prentice-Hall, Inc., 1966.

GROHMANN, M. Influências de um Curso de Pós-Graduação no Processo de Aprendizagem Gerencial. Florianópolis, 2004. Tese (Doutorado em Engenharia da Produção) - Centro Tecnológico, Universidade Federal de Santa Catarina.

GROTELUESCHEN, A.D. Assessing Reasons for Participating in Continuing Education. New Directions for Continuing Education. 27. P.33-43. 1985

GUGLIELMINO, Lucy Madsen. Development of the Self-Directed Learning Readiness Scale. Georgia, 1977. Dissertação (Doctor of Education). Georgia University.

HAIR, Joseph F.; ANDERSON, Rolph E.; TATHAM, Ronald L.; BLACK, William C. Análise Multivariada de Dados. 5a Edição. Porto Alegre: Bookman, 2005.

HANDY, C. The Age of Unreason. Boston: Harvard Business School Press, 1990. 
HANSON, Sheila Kay. Alumni characteristics that predict promoting and donating to alma mater: Implications for alumni relations. North Dakota, 2000. Dissertation (Doctor of Philosophy in the Graduate Faculty) - University of North Dakota.

HARTREE, A. 'Malcolm Knowles' Theory of Androgogy: a Critique." International Journal of Lifelong Education, 3(3), p.203-210, 1984.

HEAP, Nick. The Design of Learning Events. Industrial and Commercial Training. Vol. 28, Iss. 2; pg. 10. Guilsborough: 1996.

HEDBERG, B. How Organizations Learn and Unlearn. In: NYSTROM, P.; STARBUCK, W. (Orgs.) Handbook of Organization Design. Oxford: Oxford University, p.3-27, 1981.

HENRY, Jane. Meaning and Practice in Experiential Learning. In: WEIL, Susan Warner; McGILL, Ian (eds). Making Sense of Experiential Learning: Diversity in Theory and Practice. Ballmoor: Open University Press, 1989.

Hergenhahn, B.R. An introduction to theories of learning. New Jersey: Prentice Hall, 1988.

HOULE, Cyril. The inquiring Mind. Madison: University of Wisconsin Press, 1961.

Investors in People. The Investors in People Standard. London: liP UK, 1995.

ISCED. International Standard Classification of Education. Quebec: Unesco Institute for Statistics, 1997.

JAMES, William. Percept and Concept: the Import of Concepts, in: McDERMOTT, J. (ed.) The Writings of William James. Chicago: University of Chicago Press, 1977.

JARVIS, P. Meaningful and Meaningless Experience: Towards an Analysis of Learning From Life. Adult Education Quarterly. Vol. 37, n.3, p.164-172. Spring, 1987.

JONHSTONE, J.W.; RIVERA, R.J. Volunteers for Learning. Chicago: Aldine, 1965.

KIDD, J.R. How Adults Learn. Chicago: Follett Publishing Company, 1973.

KNOWLES, Malcolm S. Andragogy, not Pedagogy. Adult Leadership, 16(10), p.350-352, 386, 1968.

KNOWLES, Malcolm S. Self-Directed Learning: a Guide for Learners and Teachers. New York: Cambridge Book, 1975.

KNOWLES, Malcolm S. The Modern Practice of Adult Education: From Pedagogy to Andragogy. (2nd ed.) New York: Cambridge Books, 1980.

KNOX, Alan B. Adult Development and Learning. San Francisco: Jossey-Bass, 1977. 
KOLB, David A. Experiential Learning. New Jersey: Prentice-Hall, Inc, 1984.

KOLB, David A. Management and the Learning Process. California Management Review (pre-1986). 18, 3, p.21-31.; ABI/INFORM Global. Spring, 1976.

LAVE, J.; WENGER, E. Situated Learning: Legitimate Peripheral Participation. Cambridge: Cambridge University Press, 1991.

Le BOTERF, G. De la Competénce à la Navigation Profissionnelle. Paris : Les Éditions d'Organisation, 1998.

Le DEIST; Françoise Delamare; WINTERTON, Jonathan. What is Competence. Human Resource Development International, vol.8, n.1, p.27-44, march, 2005.

LEDERMAN, Ellen. Maintaining Competence: Understanding How professional Learn. Toronto: 1998. Tese (doutor em educação). Universidade de Toronto.

LEITE, I.; GODOY, A.; ANTONELLO, C. O Aprendizado da Função Gerencial: os Gerentes como Atores e Autores do seu Processo de Desenvolvimento. Aletheia, n.23, p.7-41, jun. 2006.

LORGE, I. Intellectual Changes during Maturity and Old Age. Review of Educational Research, 14(4), p.438-443, 1944.

LUCENA, E. A Natureza da Aprendizagem de Gerentes-Proprietários do Setor de Varejo de Vestuário de Florianópolis. Florianópolis, 2001. Tese (Doutorado em Engenharia da Produção) - Centro Tecnológico, Universidade Federal de Santa Catarina.

MAINEMELIS, Charalampos; BOYATZIS, Richard; KOLB, David A. Learning Styles and Adaptative Flexibility: Testing Experiential Learning Theory. Management Learning, vol. 33, 1, p.5. Sage Publications: London, Mar, 2002.

MALHOTRA, Naresh K. Pesquisa de Marketing: uma Orientação Aplicada. $3^{2} E d$. Porto Alegre: Bookman, 2002.

MARSICK, Victoria J.; WATKINS, Karen E. Informal and Incidental Learning in the Workplace. New York: Routledge, 1990.

MARSICK, Victoria J.; WATKINS, Karen E. Informal and Incidental Learning. New Directions for Adult and Continuing Education, n.89 p.25-34. Spring, 2001.

MARSICK, Victoria J.; WATKINS, Karen E.; CALLAHAN, Mary Wilson; VOLPE, Marie. Reviewing Theory and Research on Informal and Incidental Learning. Paper presented at the Academy of Human Resource Development International Conference (AHRD) (Columbus, OH,) p794-800 (Symp. 38-2), Feb 22-26, 2006.

MARTON, F.; HOUNSELL, D.; ENTWISTLE, N. The experience of Learning. Edinburgh: Scottish Academic Press, 1984.

McCLELLAND, D. Testing for Competence rather than for Intelligence. American Psychologist, 28(1), p.1-14. 1973. 
MEISTER, Jeanne C. Educação Corporativa: a Gestão do Capital Intelectual através das Universidades Corporativas. São Paulo: Pearson Makron Books, 1999.

MERRIAM, S.; CAFFARELLA, R. Learning in Adulthood: a comprehensive guide. Jossey-Bass: San Francisco, 1991.

MEZIROW, J. Understanding transformation theory. Adult Education Quarterly, v. 44, n. 4, p. 222-232, 1994.

MILLER, H.L. Teaching and Learning in Adult Education. New York: Macmillan, 1964.

MITCHELL, Luís Henrique Raja Gabaglia. Gestão de Pessoas por Competências no Ambiente AulaNet. Rio de Janeiro, 2003. Dissertação (Mestrado em Informática) - Pontifícia Universidade Católica do Rio de Janeiro, Conselho Nacional de Desenvolvimento Científico e Tecnológico.

MOCKER, D.W.; SPEAR, G.E. Lifelong Learning: Formal, Non-Formal, Informal and Self-Directed. Columbus, OH: ERIC Clearinghouse on Adult, Career and Vocational Education, 1982.

MORAES, Liege Viviane dos Santos de. A Dinâmica da Aprendizagem Gerencial: o Caso do Hospital Moinho de Ventos. Florianópolis, 2000. Dissertação (Mestrado em Engenharia da Produção) - Centro Tecnológico, Universidade Federal de Santa Catarina.

MORAES, Liege Viviane dos Santos de. Um Modelo para a Análise do Processo de Aprendizagem de Empreendedores. Universidade Federal de Santa Catarina: Florianópolis, [sd].

MORAES, Liege Viviane dos Santos; SILVA, Maria Aparecida da; CUNHA, Cristiano J.A.C. Aprendizagem Gerencial: Teoria e Prática. RAE Eletrônica, V.3, n.1, jan/jun: 2004a.

MORAES, Liege Viviane dos Santos; SILVA, Maria Aparecida da; CUNHA, Cristiano J.A.C. A Dinâmica da Aprendizagem Gerencial em um Hospital. ERA Eletrônica, v.3, n.2, Art.18, jul./dez. 2004b.

MORSTAIN, Barry R.; SMART, John C. Reasons for Participation in Adult Education Courses: A Multivariate Analysis of Group Differences. Adult Education, 24, 2, p.8398. 1974.

MUMFORD, A. How Managers Can Develop Managers. Gower: Aldershot, 1993

MURPHY, Kevin M.; WELCH, Finis. Empirical Age-earnings Profiles. Journal of Labor Economics, 8. P.202-229. April, 1990.

NORDHAUG, Odd. Competence Specificities in Organization. International Studies of Management \& Organizationan White Plains, v.28, n.1, p.8-29, Spring, 1998.

O'CONNELL, Philip J. Adults in Training: An International Comparison of Continuing Education and Training. CERI/WD (99) 1. OECD, Paris. 1999. 
OECD. Definition and Selection of Competencies: Theoretical and Conceptual Foundations (DeSeCo): Strategy Paper on Key Competencies, a Frame of Reference for a Coherent Assessment and Research Program. DEELSA/ED/CEI/CD Paris: OECD publishing, 2002.

OECD. Education and Training: Learning and Working in a Society in Flux. Paris: OECD publishing, 1996.

OECD. Education at a Glance: OECD Indicators. Paris: OECD publishing, 2008a.

OECD. Job-Related Training and Benefits for Individuals: A review of evidence and explanations. OECD Education Working Paper Series, N. 19. Paris: OECD publishing, 2008b.

Organização Internacional do Trabalho. Certificação de Competências Profissionais: Análise Qualitativa do Trabalho, Avaliação e Certificação de Competências - Referenciais Metodológicos. Reedição Brasília : OIT, 2002.

PARRY, Scott B. The Quest for Competencies. Training, 33, 7, p.48-56, July, 1996.

PEARSON, M.; SMITH, D. Debriefing in Experience-Based Learning. p.69-84. In: BOUD, D.; KEOGH, R.; WALKER, D. (eds). Reflection: Turning Experience into Learning. Kogan Page/Nichols Publishing Co.: London/New York, 1985.

PEDLER, M.; BOYDELL, T.; BURGOYNE, P. Towards the Learning Company. Management Education and Development, Vol.20, No.1, p.1-8. 1989.

PESTANA, Maria Helena; GAGEIRO, João Nunes. Análise de Dados para Ciências Sociais: a Complementaridade do SPSS. $2^{a}$ ed. Revisada e aumentada. Lisboa: Edições Sílabo, 2000.

PETERSON, R.E.; ASSOCIATES. Lifelong Learning in America. San Franciso: Jossey-Bass, 1979.

PIAGET, Jean. A Linguagem e o Pensamento da Criança. Trad. Manuel Campos. São Paulo: Martins Fontes, 1986.

PIAGET, Jean. The origins of Intelligence in Children. New York: International University Press, 1952.

PIAGET, Jean. The place of the Sciences of Man in the System of Sciences. New York: Harper Torchbooks, 1970.

PLOVNICK, M.S. A Cognitive Ability Theory of Occupational Roles. MIT School of Management. Working Paper, n.524-71, Spring 1971.

POSSAMAI, FABÍOLA. A Influência da Cultura da Organização na Aprendizagem de Executivos: o caso da Tigre. Florianópolis, 2005. Tese (doutorado em engenharia de produção) Universidade Federal de Santa Catarina.

PRAHALAD, C.K.; HAMEL, G. Competindo pelo futuro. $20^{2} \mathrm{ed}$. Rio de Janeiro: Elsevier, 2005. 
PRATT, D. D. Andragogy after Twenty-Five Years. In: MERRIAM, S. B. (org.). Update on Adult Learning Theory: New Directions for Adult and Continuing Education, n.57, San Francisco: Jossey-Bass, 1993.

PUMERANTZ, Richard Kenneth. Alumni-in-training: Institutional factors associated with greater alumni giving at public comprehensive colleges and universities. California, 2004. Dissertation (Doctor of Philosophy in the Graduate Faculty of higher education) - Faculty of Claremont Graduate University.

RABAGLIO, M. O. Seleção por Competências. São Paulo: Editora Educator. 2a edição. 2001.

REYNOLDS, Margaret. Standards and Professional Practice: The TTA and Initial Teacher Training. British Journal of Educational Studies, Vol.47, N.3, p.247-260, Set 1999.

RIBEIRO, Lore M. Mânica; Guimarães, Tomás de Aquino. Competências Organizacionais e Humanas de uma Organização Financeira Estatal: o Ponto de Vista de seus Gerentes. Enanpad, 1999.

ROGERS, Carl. Freedom to Learn. Nova York: Merrill, 1980.

ROGLIO, K. O Executivo Reflexivo: Arquiteto e Facilitador de Novas Configurações Organizacionais. Florianópolis, 2006. Tese (Doutorado em Engenharia da Produção) - Centro Tecnológico, Universidade Federal de Santa Catarina.

RYLE, G. O conceito de espírito. Moraes: Lisboa, 1970.

SALVADOR, C.C. Aprendizagem Escolar e Construção do Conhecimento. Porto Alegre: Artes Médicas, 1994.

SAVICEVIC, Dusan M. Modern Conceptions of Andragogy: a European Framework. Studies in the Education of Adults, 23(2), p.179-201, 1991.

SCHAIE, K.W.; WILLIS, S.L. Adult Development and Aging. (2nd ed.) Boston: Little Brown, 1986.

SCHEIN, E.H.; KROMER, D.W. Professional Education. McGraw Hill: New York 1972.

SCHÖN, D.A. Educating the Reflective Practitioner. Jossey-Bass Inc.: San Francisco, 1987.

SCHÖN, D.A. The Reflective Practitioner: How Professionals Think in Action. Maurice Temple Smith: London, 1983

SCHRODER, H.M. Managerial Competence: the Key to Excellence. lowa: Kendall/Hunt, 1989.

SENGE, Peter. The Fifth Discipline: the Art and Practice of the Learning Organization. Ed. Transword, 1990. 
SFARD, A. On Two Metaphors for Learning and the Dangers of Choosing just One. Educational Researcher, 27 (2): 4-13, 1998.

SHAPIRO, Michele Margit. How Professionals Learn to Make Involuntary Career Changes Succesfully. New York, 1994. Dissertation (Doctor of Education). Columbia University.

SHARMA, Subhash. Applied Multivariate Techniques. New York: John Wiley \& Sons Inc., 1996.

SHEFFIELD, S.B. The Orientations of Adult Continuing Learners. In: SOLOMON, D. (org.). The Continuing Learner. P.9-15. Chicago: Center for the Study of Liberal Education for Adults, 1964.

SHRIVASTAVA, P. A Typology of Organizational Learning Systems. Journal of Management Sudies, v.20, n.1, p.7-28, 1983.

SILVA, A.; REBELO, L.; CUNHA, C. Aprendizagem de Gerentes: a Perspectiva da Experiência Vivida. In: ENCONTRO ANUAL DA ANPAD, XXX, 2006. Anais. Salvador: Associação Nacional dos Cursos de Pós-Graduação em Administração, 2006.

SILVA, Gerlando Augusto Sampaio de Franco. Utilização da Teoria de Divulgação para Avaliação da Relação do Nível de Disclosure com o Custo da Dívida das Empresas Brasileiras. São Paulo, 2007. Tese (Doutorado em Ciências Contábeis) - Programa de Pós-Graduação em Ciências Contábeis, Departamento de Contabilidade e Atuária, Faculdade de Economia, Administração e Contabilidade da Universidade de São Paulo.

SILVA, Rejane Maria da. Aprendizagem e Competências de Gestores da Superintendência Regional Nordeste da INFRAERO. Recife: 2008. Mestrado em Administração. Universidade Federal de Pernambuco.

SIMPSON, E.J. The Classification of Educational Objectives in the Psychomotor Domain. Washington, DC: Gryphon House, 1972.

SMITH, R.M. Learning How to Learn: Applied Learning Theory for Adults. New York: Cambridge Books, 1982.

SPARROW, Paul R.; BOGNANNO, Mario. Competency requirement forecasting: issues for international selection and assessment. In: Managing Learning. MABEY, Christopher \& ILES, Paul. (eds) London: Routledge, 1994.

SPENCER, Lyle M. \& SPENCER, Signe M. Competence at work: models for superior performance. New York: John Wiley \& Sons, 1993.

STARR, P. The Social Transformation of American Medicine. Basic Book: New York, 1982.

STEVENS, Margaret. An investment Model for the Supply of General Training by Employers. Economic Journal. N. 104, P. 556-570. May, 1994. 
THORNDIKE, E.L. et al Adult Learning. New York: Macmillan, 1928.

TOUGH, Allen M. The Adult's Learning Projects: A Fresh Approach to Theory and Practice in Adult Learning. $2^{\text {nd }}$ ed. Austin, Texas: Learning Concepts, 1979.

UNESCO. Annual Report 2007. UNESCO-UIL (United Nations Educational, Scientific and Cultural Organization - Institute of Lifelong Learning). Acessado em 22 de dezembro de 2008.2 Disponível em: http://www.unesco.org/uil/en/UILPDF/nesico/annreport07/us/JB07Engl.pdf

USP. Anuário Estatístico da USP. Acessado em: 22 dezembro de 2008. Disponível em: http://sistemas.usp.br/anuario/r tabelas.htm

VESPEREJ, M.A. Formal Training: Secondary Education? Industry Week, 247 (1), 42-44.

VYGOTSKY, L.S. Thought and Language. New York: John Wiley \& Sons, 1962.

WALKER, D. Writing and Reflection. P.52-68. In: BOUD, D.; KEOGH, R.; WALKER, D. (eds). Reflection: Turning Experience into Learning. London/New York: Kogan Page/Nichols Publishing Co., 1985.

WEICK, K.E. The Non-Traditional Quality of Organizational Learning. Organization Science, v.2, n.1, p.116-124, 1991.

WEINERT, F.E. Concept of Competence: a Conceptual Clarification. In: WYCHEN, D.S. \& SALGANIK, L. H. (Eds) Defining and Selecting Key Competencies, p.4566. Göttingen: Hogrefe, 2001.

WHITE, R. Motivation Reconsidered: the Concept of Competence. Psychological Review, 66, p.279-333, 1959.

WOLFE, J. Learning Styles Rewarded in a Complex Simulation with Implications for Business Policy and Organizational Behavior Research. Academy of Management Proceedings, 1977.

WORLD BANK. Lifelong Learning and the Knowledge Economy. Summary of the Global Conference on Lifelong Learning organizer by the World Bank. the BadenWürttemberg Foundation for Development Cooperation, and the German State of Baden-Württemberg. Stuttgart, 2002.

WORLD BANK. Lifelong Learning in the Global Knowledge Economy: Challenges for Developing Countries. Washington: The World Bank, 2003.

WORLD BANK. Priorities and Strategies for Education: a World Bank Review. Washington: The World Bank, 1995.

YUKL, G.A. Leadership in Organizations. $2^{\underline{a}}$ ed. Englewood Cliffs, NJ: PrenticeHall, 1989. 
ZARIFIAN, PHILLIPPE. Compétence et Organization Qualifiante en Milieu Industriel. In: MINET, Francis; PARLIER, Michel; WITTE, Serge. La Competénce: Mythe, Construction ou Realité? Paris: Liaisons, 1994.

ZARIFIAN, PHILLIPPE. Objectif Compétence. Paris : Les Éditions Liaisons 1999. 


\section{ANEXOS}

\section{Anexo 1 - Convite para responder a pesquisa:}

Prezado(a) ex-aluno(a) da FEA-USP,

Convidamos a participar da pesquisa "A relação entre grupos de eventos de aprendizagem e o desenvolvimento de competências individuais", que além de fazer parte da dissertação do mestrando em administração Wagner Toyama Cassimiro, ampliará a nossa compreensão sobre como as pessoas aprendem no trabalho e contribuirá para uma reflexão do respondente em relação ao seu próprio desenvolvimento.

O questionário dura cerca de 7 minutos para ser preenchido e não há necessidade de identificação. Pedimos a devida atenção e sinceridade para aqueles que aceitarem este convite. O prazo para resposta é até 16 de outubro.

Para os que tiverem interesse, os resultados da pesquisa serão divulgados por e-mail após a defesa da dissertação, prevista para novembro de 2008, e também será agendada uma apresentação com as principais conclusões do estudo.

Caso tenha interesse de entrar em contato com o pesquisador, seu email é wagnertc@usp.br e o de sua orientadora, Profa. Dra. Marisa Pereira Eboli, é meboli@usp.br .

Certos de seu apoio,

FEA +: Programa de Relacionamento com Ex-alunos

Faculdade de Economia, Administração e Contabilidade da USP 


\section{Aprendizagem e Competência}

\section{I ntruções gerais}

Prezado(a) ex-aluno(a) da FEA-USP,

convidamos a participar da pesquisa "A relação entre os eventos de aprendizagem e o desenvolvimento de competências individuais", que além de fazer parte da dissertação do mestrando em administração Wagner Toyama Cassimiro, ampliará a nossa compreensão sobre como as pessoas aprendem no trabalho e contribuirá para uma reflexão do respondente em relação ao seu próprio desenvolvimento.

O questionário dura cerca de 7 minutos para ser preenchido e não há necessidade de identificação. Pedimos a devida atenção e sinceridade para aqueles que aceitarem este convite. O prazo para resposta é até 23 de outubro.

Para os que tiverem interesse, os resultados da pesquisa serão divulgados por e- mail após a defesa da dissertação, prevista para novembro de 2009, e também será agendada uma apresentação com as principais conclusões do estudo.

Caso tenha interesse de entrar em contato com o pesquisador, seu email é wagnertc@usp.br e o de sua orientadora, Profa. Dra. Marisa Pereira Eboli, é meboli@usp.br .

Certos de seu apoio,

FEA +: Programa de Relacionamento com Ex-alunos

Faculdade de Economia, Administração e Contabilidade da USP 


\section{Aprendizagem e Competência}

\section{Eventos de Aprendizagem e Desenvolvimento de Competências}

* 1. Em relação ao seu atual trabalho, quais dos seguintes tipos de capacidades são mais SI GNI FI CATI VOS para executá-lo? Quanto maior a nota, maior é a importância dada. Coloque "Não sei" , caso não queira/ saiba responder.

\begin{tabular}{|c|c|c|c|c|c|c|c|c|c|c|c|}
\hline & $\begin{array}{r}\text { Não } \\
\text { sei }\end{array}$ & 1 & 2 & 3 & 4 & 5 & 6 & 7 & 8 & 9 & 10 \\
\hline $\begin{array}{l}\text { Capacidade de mobilizar e interagir } \\
\text { com as pessoas. }\end{array}$ & jn & is & j & jn & jn & & $j \cap$ & jn & jn & jn & jn \\
\hline $\begin{array}{l}\text { Capacidade de cumprir tarefas e } \\
\text { executar processos. }\end{array}$ & jn & & i & jn & $j n$ & & $j n$ & $j n$ & $j n$ & jn & $j n$ \\
\hline $\begin{array}{l}\text { Capacidade de analisar e resolver } \\
\text { problemas. }\end{array}$ & jn & & & jn & jn & & jn & $j n$ & jn & jn & jn \\
\hline
\end{tabular}

* 2. Considerando o desenvolvimento da sua capacidade de MOBI LIZAR e I NTERAGI R COM AS PESSOAS, avalie as seguintes afirmações segundo a CONCORDÂNCI A atribuída. Quanto maior a nota, maior é a concordância dada. Coloque "Não sei", caso não queira/ saiba responder.
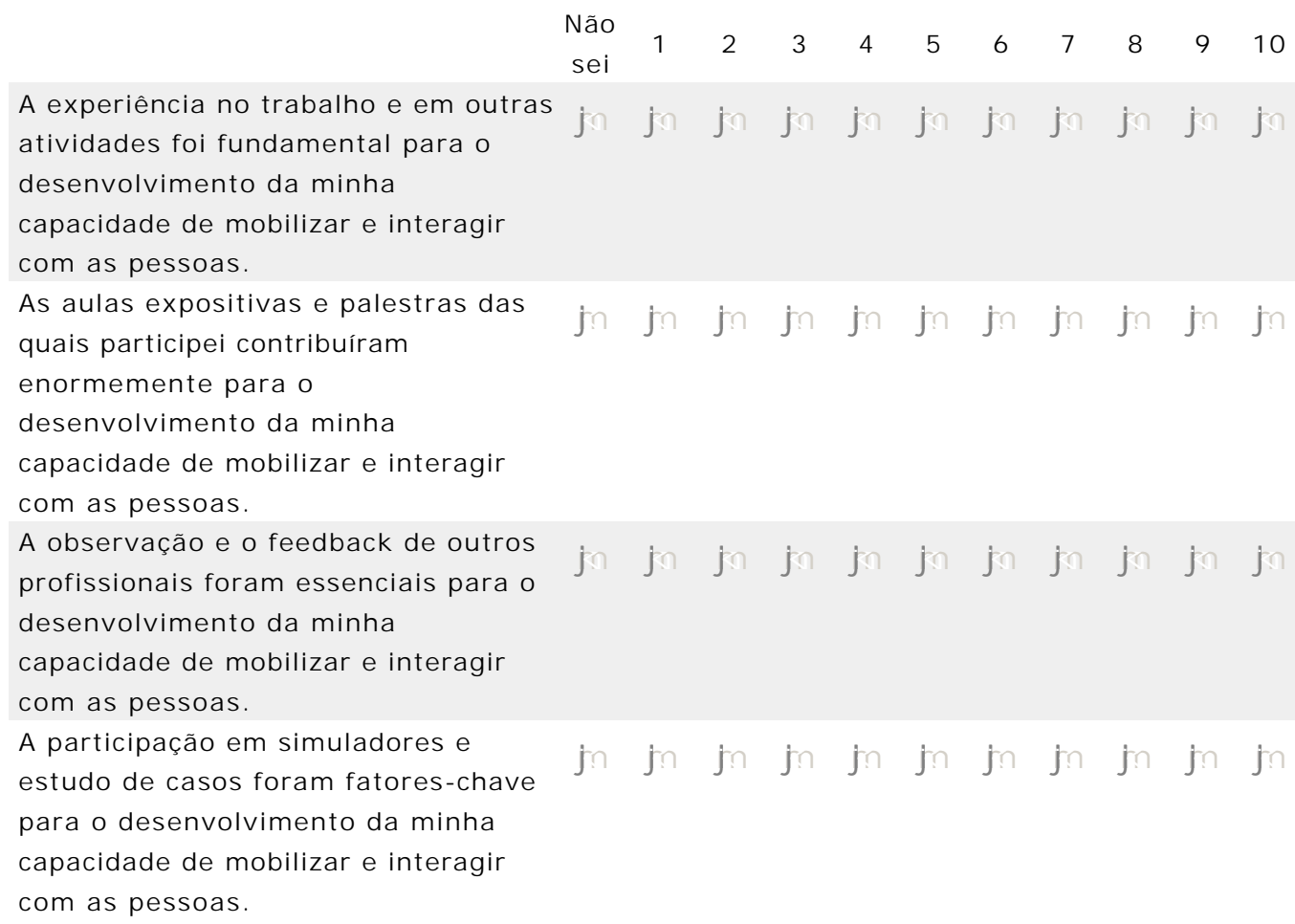


\section{Aprendizagem e Competência}

\section{* 3. Considerando o desenvolvimento da sua capacidade de CUMPRIR}

TAREFAS e EXECUTAR PROCESSOS, avalie as seguintes afirmações segundo a CONCORDÂNCI A atribuída. Quanto maior a nota, maior é a concordância dada. Coloque "Não sei", caso não queira/ saiba responder.

A experiência no trabalho e em outras
atividades foi fundamental para o
desenvolvimento da minha
capacidade de cumprir tarefas e atuar
em processos.
As aulas expositivas e palestras das
quais participei contribuíram
enormemente para o
desenvolvimento da minha
capacidade de cumprir tarefas e atuar
em processos.
A observação e o feedback de outros
profissionais foram essenciais para o
desenvolvimento da minha
capacidade de cumprir tarefas e atuar
em processos.
A participação em simuladores e
estudo de casos foram fatores-chave
para o desenvolvimento da minha
capacidade de cumprir tarefas e atuar
em processos.

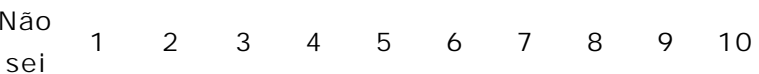

4. Considerando o desenvolvimento da sua capacidade de ANALI SAR e RESOLVER PROBLEMAS, avalie as seguintes afirmações segundo a CONCORDÂNCIA atribuída. Quanto maior a nota, maior é a concordância dada. Coloque "Não sei", caso não queira/ saiba responder.

$\begin{array}{cllllllllll}\text { Não } & 1 & 2 & 3 & 4 & 5 & 6 & 7 & 8 & 9 & 10\end{array}$

\footnotetext{
A experiência no trabalho e em outras atividades foi fundamental para o desenvolvimento da minha capacidade de analisar e resolver problemas.

As aulas expositivas e palestras das quais participei contribuíram enormemente para o

desenvolvimento da minha

capacidade de analisar e resolver problemas.

A observação e o feedback de outros profissionais foram essenciais para o desenvolvimento da minha capacidade de analisar e resolver problemas.

A participação em simuladores e estudo de casos foram fatores-chave para o desenvolvimento da minha capacidade de analisar e resolver problemas.
} 
Aprendizagem e Competência

* 5. Considerando o desenvolvimento da sua capacidade de APRENDER A APRENDER, avalie as seguintes afirmações segundo a CONCORDÂNCI A atribuída. Quanto maior a nota, maior é a concordância dada. Coloque "Não sei", caso não queira/ saiba responder.

Não

sei

A experiência no trabalho e em outras atividades foi fundamental para o

desenvolvimento da minha

capacidade de aprender a aprender.

As aulas expositivas e palestras das

quais participei contribuíram

enormemente para o

desenvolvimento da minha

capacidade de aprender a aprender.

A observação e o feedback de outros

profissionais foram essenciais para o

desenvolvimento da minha

capacidade de aprender a aprender.

A participação em simuladores e

estudo de casos foram fatores-chave

para o desenvolvimento da minha

capacidade de aprender a aprender.

Page 4 


\section{Aprendizagem e Competência}

3. Eventos de Aprendizagem e Desenvolvimento de Competências ( 2 de 3 )

\section{Avalie os seguintes eventos conforme a sua FREQUÊNCI A. Coloque "Não sei", caso não queira/ saiba responder.}

\begin{tabular}{|c|c|c|c|c|c|}
\hline & Não sei & Nunca & $\begin{array}{l}\text { Pouco } \\
\text { frequente }\end{array}$ & Frequente & $\begin{array}{l}\text { Muito } \\
\text { frequente }\end{array}$ \\
\hline 01. Assisto aulas expositivas & jn & jn & jn & jn & jn \\
\hline 02. Faço cursos de eLearning & jn & jn & jn & jn & $j n$ \\
\hline 03. Assisto palestras & jn & jn & jn & jn & jn \\
\hline $\begin{array}{l}\text { 04. Participo de treinamentos no } \\
\text { próprio ambiente de trabalho }\end{array}$ & jn & jn & jn & jn & jn \\
\hline $\begin{array}{l}\text { 05. Participo de aulas em que } \\
\text { aprendo fazendo (hands-on) }\end{array}$ & jn & jn & jn & jn & jn \\
\hline 06. Faço uso de aulas particulares & $j n$ & jn & jn & jn & jn \\
\hline 07. Recebo feedback & jn & jn & jn & jn & jn \\
\hline $\begin{array}{l}\text { 08. Converso com um mentor ou } \\
\text { tutor }\end{array}$ & jn & jn & jn & jn & jn \\
\hline $\begin{array}{l}\text { 09. Dou conselhos como mentor ou } \\
\text { tutor de alguém }\end{array}$ & jn & jn & jn & jn & jn \\
\hline $\begin{array}{l}\text { 10. Faço uso de mecanismos que } \\
\text { facilitem a compreensão de um }\end{array}$ & jn & jn & jn & jn & jn \\
\hline
\end{tabular}

facilitem a compreensão de um

problema (ex.: representação

gráfica e pensamento lateral)

11. Repito uma tarefa ou ensaio algo com o intuito de aprimorá-lo 12. Reflito sobre minhas próprias ações e comportamentos

13. Reflito sobre ações e comportamentos dos outros

14. Observo comportamentos de pessoas mais experientes ou tento fazer algo como alguém

15. Estruturo uma ideia no papel ou para uma apresentação

16. Busco mudar de perspectiva ou me colocar em outra posição para compreender um outro ponto de vista

17. Trabalho em times ou de forma colaborativa

18. Busco conectar aprendizados prévios ou de outras atividades fora do trabalho

19. Participo de projetos desafiadores ou vivencio situações difíceis

20. Aprendo por osmose

trabalhando com pessoas mais

experientes

21. Participo de simuladores

22. Participo de jogos de empresas

23. Leio estudos de caso e tento resolvê-los 


\section{Aprendizagem e Competência}

24. Leio livros e revistas

relacionados ao trabalho e profissão

jn jn jn jn 


\section{Aprendizagem e Competência}

\section{Perfil do respondente ( 3 de 3 )}

\section{Nome (opcional):}

\section{Ano de nascimento}

\section{Ano}

\section{Ano de}

nascimento:

\section{Grau máximo obtido:}

jn Graduação

jn Pós-Graduação em andamento (especialização)

In Pós-Graduação concluído (especialização)

jn Pós-Graduação em andamento (mestrado acadêmico)

jn Pós-Graduação concluído (mestrado acadêmico)

in Doutorado em andamento

jn Doutorado concluído

jn Pós-Doutorado em andamento

In Pós-Doutorado concluído

* 4. Curso de graduação na FEA ( se houver dois, considerar o mais relevante):

In Administração

jn Economia

jn Contabilidade

jn Ciências Atuariais

jn Não fiz graduação na FEA

* 5. Ano de conclusão (o mesmo do anterior):

Ano:

\section{Cidade onde vive:}

\section{Estado onde vive:}

\section{País aonde vive:}




\section{Aprendizagem e Competência}

9. Email para receber conclusões da pesquisa (opcional):

10. Status profissional atual (se houver mais de um, considerar o mais significativo):

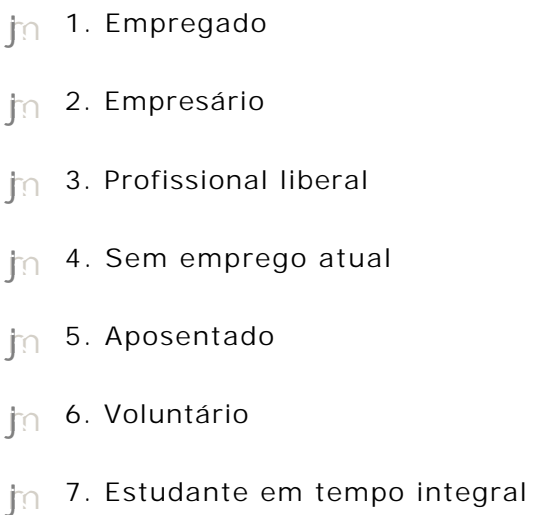

\section{Ocupação Funcional:}

Ocupação:

Se outros (especifique):

* 12. Nível hierárquico:

Nível:

\section{Cargo:}

\section{Nome da Organização:}

15. Porte:
Pequena
jn Média
in Grande

16. Setor de atividade da organização:

\section{Setor:}

Se outros (especifique): 


\section{Aprendizagem e Competência}

17. Tipo de Organização:

Tipo:

18. Tempo nesta organização:

Tempo:

19. Dúvidas, comentários, sugestões:

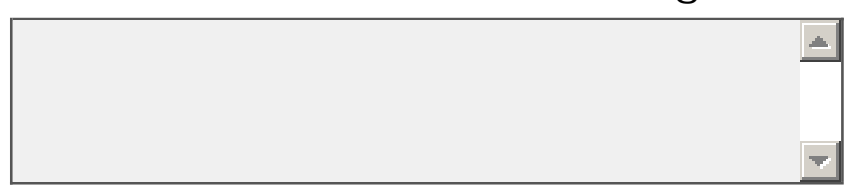

